\title{
Reining in the Crown's Authority over Dissolution: The Fixed-Term Parliaments Act of the United Kingdom versus Fixed-Date Election Laws in Canada
}

\author{
By
}

\author{
James W.J. Bowden
}

A thesis submitted to the Faculty of Graduate and Post-Doctoral Affairs in partial fulfillment of the requirements for the degree of

\author{
Master of Arts \\ in \\ Political Science \\ Carleton University \\ Ottawa, Ontario, Canada \\ September 2018 \\ (C)James W.J. Bowden \\ September 2018
}




\section{Table of Contents}

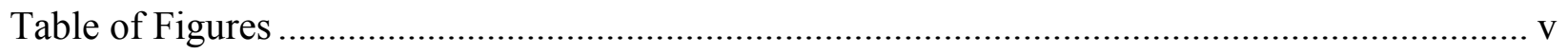

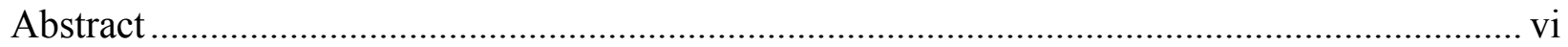

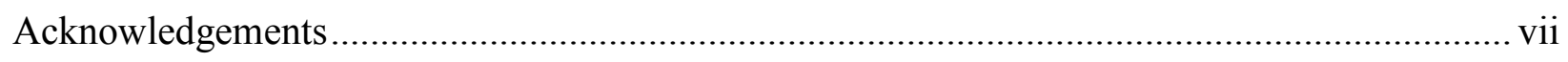

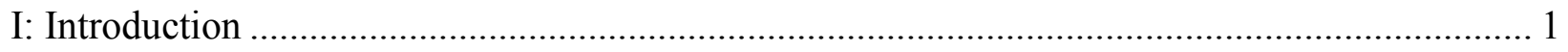

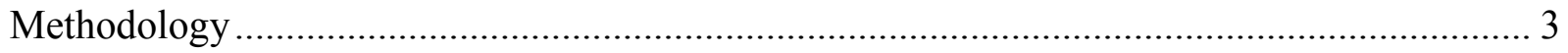

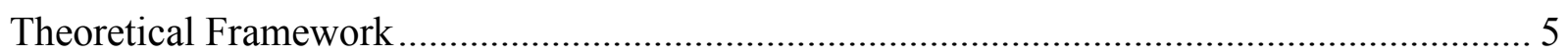

II: How the Varying Sources of Authority of the British Crown and of the Crown of Canada

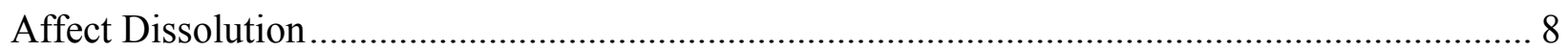

"Prerogative" versus the Authority of the Crown as a Legal Person ............................................ 8

The Three Sources of Authority of the Crown of the United Kingdom ...................................... 9

The Four Sources of Authority of the Crown of Canada.......................................................... 10

Scholars Recognize Only Two Sources of Authority of the Crown of Canada........................ 13

The Entrenchment of the Authority of the Crown and the Separation of Powers .................... 16

Analysis of the Sources on Authority of the British and Canadian Crowns and the Nature of

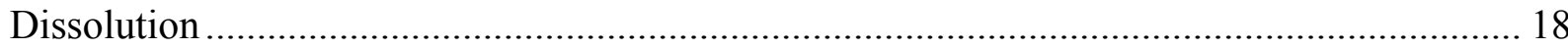

III: The Constitution of Canada and the Political Cynicism of Evading Constitutional

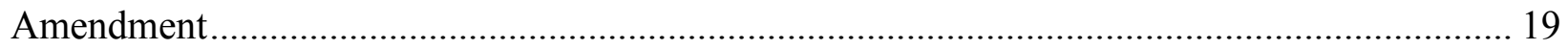

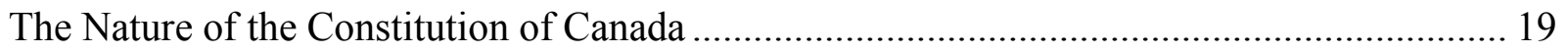

How the Constitution of Canada Limits the Scope of Fixed-Date Election Laws ................... 22

IV: Responsible Government: What It Means and How It Works ............................................... 24

The Established Constitutional Positions of the Crown and Ministers of the Crown ............... 24

How the Constitution Act, 1867 Partially Codifies Responsible Government ......................... 26

Commanding Confidence of the Crown and of the Commons................................................. 29

Achieving Harmony and Securing Liberty ……………….................................................. 29

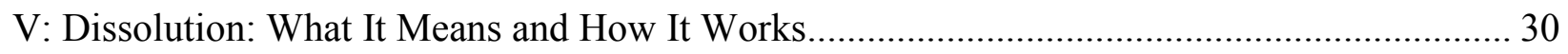

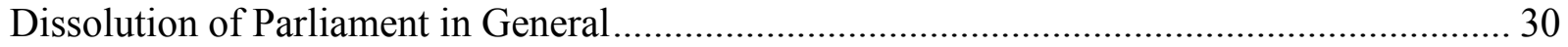

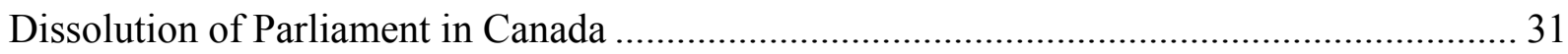

Dissolution of Parliament in the United Kingdom ............................................................. 33

VI: Historical Antecedents of Fixed-Date Elections in Canada, 1972-2008 …............................ 35

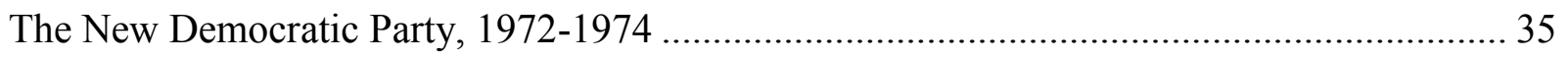


The Reform Party, the Canadian Alliance, and the Conservative Party, 1988-2007. ... 38 VII: The Early Dissolution of 2008: Constitutional Conventions and Critique of Heard, Aucoin et

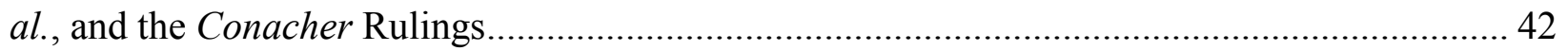

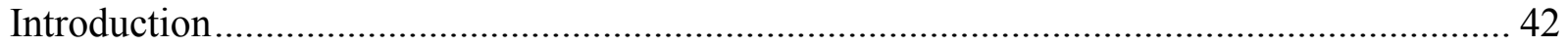

The Nature of Constitutional Conventions .................................................................. 43

Constitutional Conventions in Relation to Responsible Government and Dissolution ........... 46

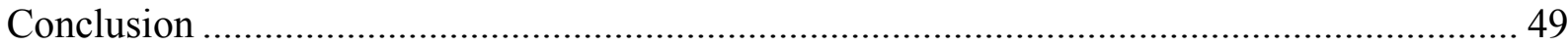

VIII: The Aftermath of the Federal General Election of 2015: Imposing Both a Minimum and

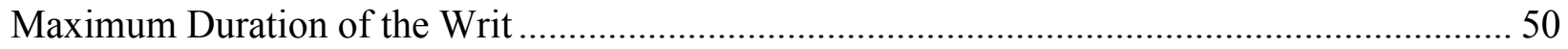

IX : Provincial Fixed-Date Election Laws in Canada, 2001-2018 ........................................ 53

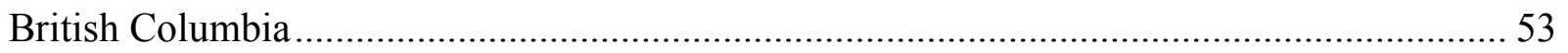

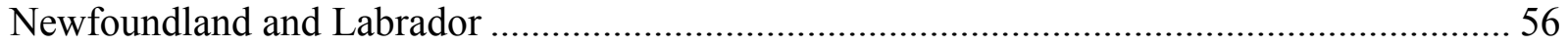

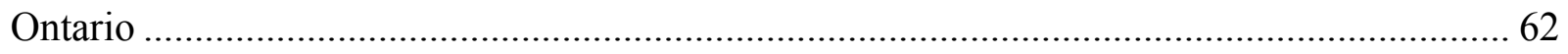

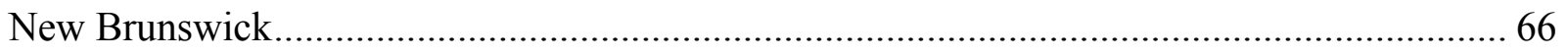

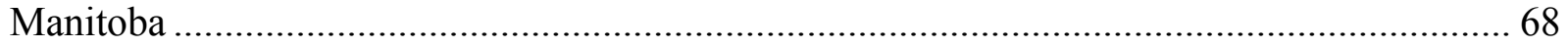

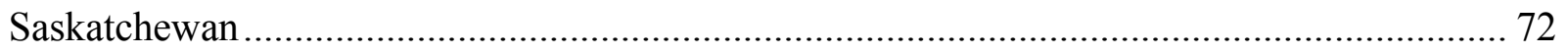

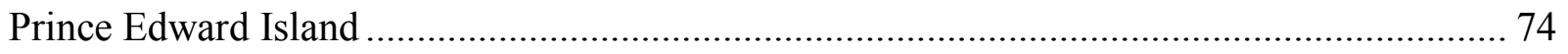

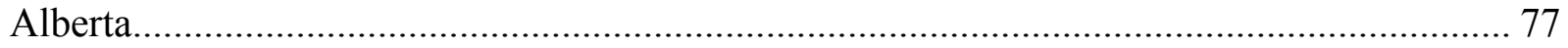

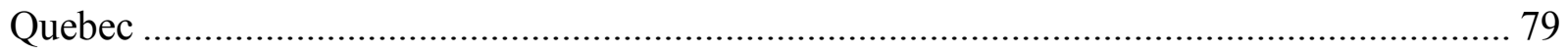

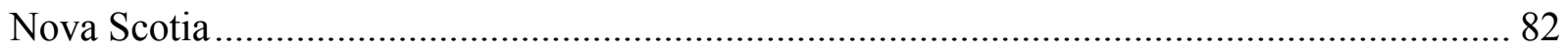

X: Territorial Fixed-Date Election Laws in Canada, 2007-2018 ........................................... 84

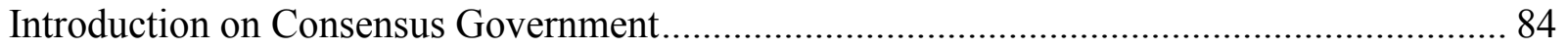

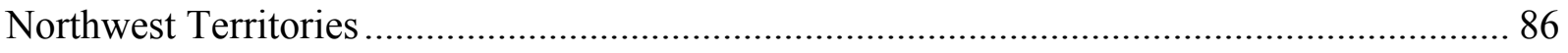

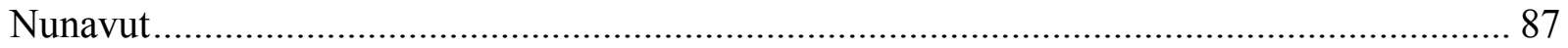

Analysis of Fixed-Date Election Laws Under Consensus Government .............................. 88

XI: There and Back Again: A Tale of Dissolution from 1640 to 2011 .................................. 89

The Waxing and Waning Prerogative of Dissolution in England and the United Kingdom .... 89

What These Statutes Show About the Nature of the Crown's Prerogative Authority............. 94

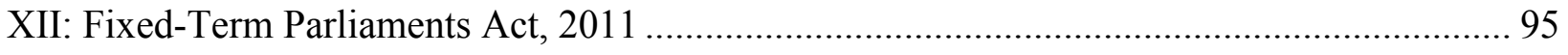

Putting the Prerogative of Dissolution into Abeyance ........................................................ 95

The Old Confidence Convention and the New Constructive Non-Confidence ....................... 96 
The Cabinet Manual and Fixed-Term Parliaments ............................................................. 98

The Subversiveness of the Fixed-Term Parliaments Act..................................................... 101 Analysis of the British Model of Fixed-Term Parliaments and the Political Motivation Behind

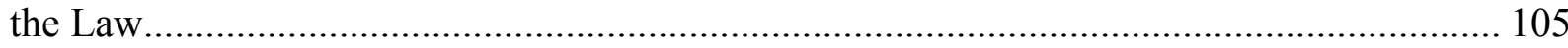

The Early Dissolution and General Election of 2017 ..................................................... 108

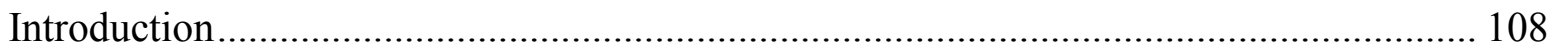

Jeremy Corbyn and Jacob Rees-Mogg Expose the Futility of the Fixed-Term Parliaments Act 108

The Indecisive and Unclear Outcome of the Early General Election of 2017................... 110

The Potential Repeal of the Fixed-Term Parliaments Act ...................................................... 112

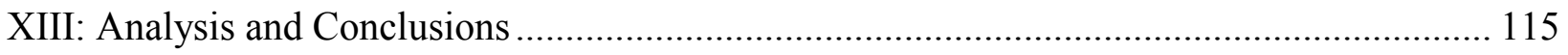

The Provinces Show the Futility of Fixed-Date Election Laws in Canada ............................. 115

Snap Elections and When Early Dissolution is Just ............................................................. 119

The Failure of the Canadian Fixed-Date Election Laws......................................................... 123

Fixed-Date Election Laws Set A New Baseline for Dissolution by Efflux of Time .............. 126

Fixed-Date Elections and the Transformation of Westminster Parliamentarism ................... 127

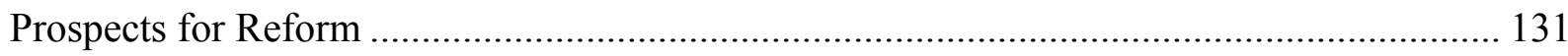

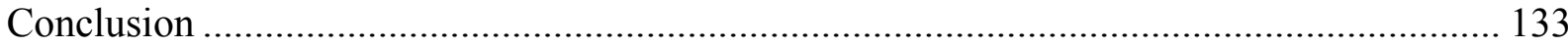

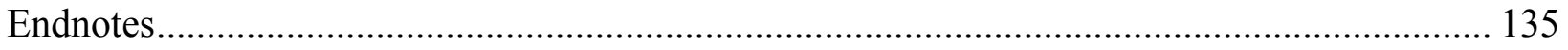




\section{Table of Figures}

Figure 1: Four Modes of Institutional Change and the Four Types of Institutional Reformers ..... 7

Figure 2: How Parliaments Are Dissolved and Elections Held in the United Kingdom............. 35

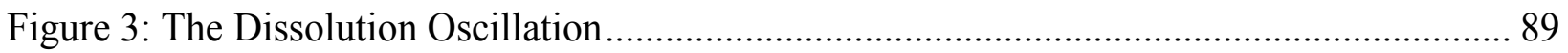

Figure 4: Timeline of Enactment by Legislature ............................................................ 115

Figure 5: Form of the Clause Preserving the Governor's Authority .................................... 116

Figure 6: Statute Containing the Provisions for Fixed-Date Elections .................................. 116

Figure 7: Timing of the Next Scheduled Elections ........................................................... 116

Figure 8: The Trouble with Timing ................................................................................ 116

Figure 9: How Federal Snap Elections Affected the Incumbent Government ........................ 122

Figure 10: The Consequences of Snap Elections Under Fixed-Term Election Laws................ 125 


\begin{abstract}
This paper analyzes the key differences between the sources of authority of the Crown of the United Kingdom versus those of the Crown of Canada in order to compare and contrast the fixed-date election laws in Canada (at the federal and provincial levels) with the Fixed-Term Parliaments Act, 2011 of the United Kingdom. The United Kingdom operates on parliamentary supremacy and an uncodified constitution; the British Parliament can therefore invoke its sovereign right to limit or put into abeyance any prerogative authority of the British Crown at will. The authority of the British Crown derives from three sources: statute, prerogative, and the Crown's capacity as a legal person. In contrast, Canada has always operated on a system of constitutional supremacy. Currently, the authority of the Crown of Canada derives from four sources: the constitutionally entrenched executive authority, the provisions of the Constitution Act, 1867, statute, and its status as a legal person. The first two sources of authority enjoy protection from statutory encroachment under section 41(a) of the Constitution Act, 1982.

This is precisely why the Canadian fixed-date elections laws have deliberately preserved the Crown's authority over dissolution and the Prime Minister's or Premier's capacity to advise and take responsibility for early dissolution. In contrast, the Fixed-Term Parliaments Act, 2011 puts the prerogative of dissolution of the British Crown into abeyance by removing the Queen and Prime Minister from dissolution altogether, and thus truly eliminates the possibility of so-called "snap elections" that First Ministers have called for their own perceived political gains. Finally, Canadian jurists and scholars have long misapplied the British concept of "prerogative" to the Crown of Canada. A.V. Dicey defined a prerogative as "the residue of discretionary or arbitrary authority, which at any given time is legally left in the hands of the Crown." Dissolution therefore cannot properly be called a "prerogative" in the Dicean sense in Canada because only a formal constitutional amendment under section 41(a) of the Constitution Act, 1982, and not a statute, could eliminate the Crown's authority over dissolution (at either the federal level or in a province) in the same manner that the Fixed-Term Parliaments Act, 2011 has put the prerogative of dissolution into abeyance in the United Kingdom. The Parliament of Canada does not enjoy the unfettered sovereignty of the Parliament of the United Kingdom.
\end{abstract}




\section{Acknowledgements}

I thank Sarah Hagen for having provided many valuable suggestions and corrections throughout this entire project, and without whose love and support this endeavour would not have been possible; Philippe Lagassé, for his insight on the sources of the Crown of Canada's authority, for his able academic mentorship, and for having introduced me to the joys of Cavalier King Charles Spaniels; Rand Dyck, for his support and encouragement over the last decade and for first trying to cultivate my scholarly potential; and Nicholas A. MacDonald, for his insight on the nature of Canada's constitution and on various other matters, our past and future collaborations, and his friendship. 


\section{I: Introduction}

The argument that the Crown's authority over dissolution gives the Prime Minister an "undemocratic" advantage and allows him to commit "abuses of power" fuelled the shift toward fixed-date elections in Canada and fixed-term parliaments in the United Kingdom. ${ }^{1}$ But that trend has manifested itself in different ways in each country. This thesis will explain why Canada and the United Kingdom have taken such divergent approaches to the same issue. Essentially, this reason flows from the differences between the Constitution of Canada and the Crown of Canada on the one hand and the British constitution and the Crown of the United Kingdom on the other; these baseline institutional features, in turn, determine what options political actors can pursue.

The political impetus behind the Canadian approach to fixed-date elections emerged after Prime Minister Chretien's two early dissolutions in 1997 and $2000{ }^{2}$ At the federal level, the Reform Party took up this cause in 1988 and pursued it in the 1990s; the Canadian Alliance further championed it in the 2000s, and the Conservative government of Prime Minister Harper finally implemented it in 2007. ${ }^{3}$ British Columbia passed the first Canadian fixed-date election law in 2001, and other provinces began to follow suit in 2004. As of 2018, all provinces except Nova Scotia have passed similar laws. Conservative, Liberal, and New Democratic governments have all introduced similar bills in nine provinces, and all have defended their initiative using the same basic arguments. These laws were designed to prevent the so-called "snap elections," where a First Minister advises an early dissolution without first having lost a vote of confidence in the assembly in order to take advantage of the government's superior position in the public opinion polls. However, Prime Minister Harper in 2008, Premiers Marois and Wynne in 2014, and Premiers Prentice and MacLauchlan in 2015 all advised early dissolution on their own terms and in so doing highlighted the fundamental feature that all the Canadian laws share: a nonderogation clause preserving the Governor's authority over dissolution. In other words, these laws deliberately preserve the executive authority of the Crown and the respective constitutional positions of the Governor and First Minister. ${ }^{4}$

With respect to fixed-date election laws in Canada, scholars have tended to concentrate on normative propositions that such laws would increase voter turnout and normative assertions that they are inherently more democratic and would thus help eliminate the "democratic deficit." However, such scholars focused on normative questions at the expense of the legal-constitutional mechanism and process by which they could achieve their lofty political ideals; they focused on why the legislature should wield more authority instead of analysing the true nature of executive authority. Consequently, they led themselves astray. After advising an early dissolution in 2008, Prime Minister Harper raised much consternation from his political opponents but surprisingly little debate on the overall effectiveness of the Canadian model of fixed-date election laws.

The Canadian fixed-date election laws do not derogate from the Crown's authority over dissolution precisely because only a constitutional amendment under section 41(a) of the Constitution Act, 1982 could significantly limit or eliminate these and other constitutionally entrenched authorities of the Crown. In addition, no statute or constitutional amendment could limit the authority and discretion of the First Minister to advise dissolution without necessarily also limiting the Governor's authority to promulgate that act of the Crown. The Canadian fixed- 
date elections laws attempt to create a new constitutional convention, paradoxically through the imposition of statute, even though, by definition, conventions develop organically. While they have not created any new constitutional conventions to constrain the First Minister's capacity to advise the Governor on dissolution, the Canadian laws now limit the maximum life of a parliament to somewhere between four and five years instead of five years. ${ }^{6}$

In contrast, the Westminster Parliament has taken a more effective and entirely different approach. Unlike any of the Canadian fixed-date election laws, the Fixed-Term Parliaments Act, 2011 of the United Kingdom has put the executive prerogative authority of the British Crown on dissolution into abeyance and transferred the authority to the legislature; from May 2015 onward, the British Parliament will now dissolve itself automatically every five years and can only be dissolved sooner under two special conditions. In other words, this law ensures that the Queen no longer dissolves Parliament on and in accordance with the advice of the Prime Minister, who can no longer advise "snap elections." The Westminster Parliament now dissolves in accordance with the statutory authority contained within the Fixed-Term Parliaments Act itself.

In this thesis, I set out to analyse the question of how the Parliament of Canada and the provincial legislatures implemented fixed-date election laws, versus how the British Parliament dealt with the same through the Fixed-Term Parliaments Act. This hinges upon the nature of the sources of authority of the Canadian Crown, which differs in some significant ways from those of the British Crown. I will therefore discuss the three sources of authority of the British Crown versus the four sources of authority of the Canadian Crown, contrast British parliamentary sovereignty with Canadian constitutional supremacy, and show why the prerogatives of the British Crown are equivalent to the constitutionally entrenched authorities of the Canadian Crown. The Crown's authority over dissolution and the attempts to limit dissolution by statute make a perfect case study on the Constitution of Canada, because dissolution pertains to both the Constitution Acts and to the constitutional conventions and principles integral to Responsible Government. The "office of the Queen, the Governor General and the Lieutenant Governor of a province" of section 41(a) of the Constitution Act, 1982 has constitutionally entrenched the authorities of the Crown, which include dissolution and the constitutional conventions that govern the relationship between the Governor and First Minister. Therefore, only an amendment under section 41(a) could eliminate the Crown's authority over dissolution and truly remove the "politics" from dissolution.

More broadly, I will also highlight some inconsistencies in the Canadian jurisprudence on "prerogative" and show that the judiciary has neither fully considered nor ruled with any consistency on the various sources of authority of the Crown of Canada, probably because Canadian jurists have relied too heavily on British jurisprudence and overlooked how the Crown of Canada has diverged from its British progenitor. Canadian jurists should re-evaluate the nature of the so-called "prerogative" authority of the Crown of Canada because this constitutionally entrenched authority is subject to a constitutional amendment and not to the legislative authority of the Parliament of Canada or a provincial legislature alone. They are therefore also not "prerogatives" per se, at least not under Dicey's definition, which Canadian courts have almost universally adopted. The separation of powers and constitutional supremacy shield the constitutionally entrenched sources of authority of the Crown of Canada from statutory encroachment. The nature and sources of authority of the Crown have a significant bearing on 
prorogation and dissolution, and thus on fixed-date election laws. ${ }^{7}$ I also provide an overview of all the fixed-date election laws in Canada and highlight some of the minor differences amongst them.

\section{Methodology}

Overall, I have adopted a qualitative method, based on content analyses of primary sources and the secondary scholarship. First, I describe the nature of executive authority of the Crown of the United Kingdom versus that of the Crown of Canada; I then compare and contrast the two in order to show how this foundational source of executive authority in general affects things which flow from it, namely executive authority over dissolution of parliament in particular.

The first main section of this paper compares and contrasts the four sources of authority of the Crown of Canada versus the three sources of authority for the Crown of the United Kingdom as a prolegomena and explanation for why the Canadian model of fixed-date election laws and the British Fixed-Term Parliaments Act take different approaches. The different structures of the institutions constrain how political actors can effect change, and it determines what kind of reforms could be made and how extensive they could be. The differences between the sources of executive authority in Canada and the United Kingdom flow mainly from the differences between the constitutions of the two countries, with the uncodified British constitution exemplifying the classical tradition of the nomos and remaining subject entirely to parliamentary sovereignty, versus the hybrid Constitution of Canada, which consists of both codified provisions and uncodified principles and conventions and functions as supreme law not subject to unfettered parliamentary sovereignty. Lastly, Canada's territories provide an additional intra-Canadian example of how the sources and nature of the Crown's executive authority determines how far fixed-date election laws can go in limiting or abolishing that executive authority over dissolving parliaments. This section relies mainly on secondary sources and the established literature in history and political science, but it also includes my analysis of the relevant judicial rulings.

In general, I take a practical approach in describing precisely what Responsible Government and dissolution are and how they are, in fact, promulgated and back up these descriptions with primary sources, like executive instruments and documentation obtained from Access to Information requests. I then delve into the extensive content analyses of fixed-date election laws in Canada and the Fixed-Term Parliaments Act of the United Kingdom, along with some antecedent English and British statutes which affected the dissolution of parliament, followed by a content analysis comparing and contrasting the two countries' precedents. My "dataset," or "sample," in this section consists of historical and contemporary primary sources.

The Canadian dataset of primary sources include the final, enacted versions of the federal, provincial, and territorial fixed-date election statutes themselves, as well as the legislative debates and committee proceedings which led to those statutes. I have also included the legislative debates on fixed-date election statutes which did not become law and compared these to the bills which were enacted. At the federal level, the earliest fixed-term parliament bills date back to the 1970s to the first, failed phase of this sort of legislation in Canada, while all the 
provincial and territorial laws date from the second successful phase which began in practice in 2001 but which originate in principle in the 1990s. In addition to these legislative sources, the sub-section on the federal fixed-date election law also examines the rulings of the Federal Court and Federal Court of Appeal on the constitutionality of the early federal election of 2008 as well as primary judicial documents, like factums, associated with these cases. The general analysis comparing Canadian fixed-date election laws also includes various secondary sources, some of which I endorse and others which I wholeheartedly refute and critique.

The sections devoted to the various Canadian fixed-date election laws and the English and British antecedents to the Fixed-Term Parliaments Act rely more on primary sources, especially in the analysis of legislative proceedings. But the analyses combine my assessments of the primary sources and critiques of secondary sources by other scholars. For instance, I have examined the text of the bills, all the legislative debates and committee proceedings, and the final text of the statutes. This gives a full picture of the legislative intent, legislative history, and effects of these laws. Generally, the legislative debates on the Canadian fixed-date election bills at Second Reading showcased the most political and least nuanced assertions of how fixed-date elections would work in practice - exemplifying the concept of over-selling and under-delivering - while the proceedings of the committee on those bills provided more detail, often more candid responses from the Minister of the Crown who introduced the bill (usually the Attorney General), and, crucially, expert testimony from government lawyers.

The legislative history and intent of these bills can only be discerned by looking at the whole legislative process, from First Reading to Royal Assent, and cannot exclude the committee stage. Some scholars made the mistake of focussing only on the general and rhetorical statements that ministers made at Second Reading without taking into account what ministers and senior civil servants said at committee, and they therefore ended up drawing the wrong conclusions. I have supplemented those with direct quotes from Ministers of the Crown where they have made important announcements outside the legislature - a trend which has become too increasingly common in Canada. These come from reputable sources of record like CBC News and The Globe and Mail. After quoting relevant portions of the Hansard, proceedings of the committee stage (which, in most provinces, were Hansard from the committee-of-the-whole), I compare and contrast in text and in charts the various features of the Canadian fixed-date election laws, how they worked within their own jurisdiction, and how they influenced the laws and practices of other jurisdictions; I then draw conclusions on the true effects of Canada's fixed-date election laws.

With respect to the United Kingdom, the primary sources pertain mainly to the FixedTerm Parliaments Act, 2011, such as the legislative debates and committee proceedings which led to the final, enacted statute, as well as some sources from the political executive, like the Cabinet Manual. This section also includes previous English and British statutes pertaining to dissolution from 1649 to 1911 for comparison. And I examine the legislative debates and subsequent political news coverage of the early general election of 2017, which happened in accordance with one of the two procedures for early dissolution outlined in the Fixed-Term Parliaments Act. Third, I tie together these comparative and historical threads and compare and contrast the Canadian fixed-date election laws and the British Fixed-Term Parliaments Act and 
draw general conclusions on both approaches and related them back to the theoretical framework throughout.

\section{Theoretical Framework}

Kathleen Thelen's and James Mahoney's “Theory of Gradual Institutional Change” serves as the theoretical framework of this thesis. It proved apt and fits so perfectly, perhaps because Thelen and Mahoney built their theory by looking at how British political institutions, like the House of Lords, have evolved over time. ${ }^{8}$ They reject the common fixation on "exogenous shocks" and deterministic path dependency alike; instead, they look to how political actors working within institutions change them. Mahoney and Thelen describe institutions as "relatively enduring features of political and social life (rules, norms, procedures) that structure behaviour and that cannot be changed easily or instantaneously." 9 In most institutions, continuity and change become "inextricably linked", locked in mortal combat like an unstoppable force meeting an immovable object. ${ }^{10}$

Mahoney and Thelen argue that rather than studying the more subtle and often more significant endogenous and gradual evolution that naturally occurs within institutions, historical institutionalists tend to over-emphasize exogenous shocks as inflection points of change that break a punctuated equilibrium. Historical institutionalism must take into account both exogenous shocks and endogenous gradual change, particularly because the latter often bring about more consequential changes than the former. ${ }^{11}$ Sociological institutionalists, in particular, privilege exogenous shock over endogenous evolution because they focus on "noncodified, informal conventions and collective scripts that regulate human behaviour" and believe that political actors "are socialized or otherwise learn to follow them." 12 This pertains to constitutional conventions.

They also argue against the concept of path dependency and instead suggest that institutions rarely if ever remain "locked in" because they "normally evolve in more incremental ways." ${ }^{\prime 13}$ Path dependency gives false impressions of a locked-in continuity and the idea that only reformers must work to change an institution; in fact, maintaining the status quo often requires active intervention on the part of conservatives. Sometimes institutions tend toward change; other times, to continuity. As Thelen and Mahoney point out, "ensuring such continuity requires the ongoing mobilization of political support as well as, often, active efforts to resolve institutional ambiguities in their favour." 14 For instance, institutions remain "vulnerable to shifts", particularly if the institution resulted from a "relatively durable though still contested settlement"15 - such as, for instance, England and Great Britain from 1688 until the last Jacobite Rebellion in 1745, where Catholic extremists sought to overturn the Protestant Succession through violence and restore the Catholic Stuarts to the throne.

As such, "institutional stability ultimately depends not only on continuity in the rules themselves but also on the ways in which those rules are instantiated in practice." 16 In other words, political actors must accept the norms which underpin written, formal rules before they can reinforce them in practice. Without that normative foundation and underlying lifeforce, written rules and formal procedures become meaningless. Under the Thelen-Mahoney Model, the capacity for change flows from the "power-distributional implications" inherent to political 
institutions, and gradual change occurs in the "'gaps' or 'soft spots' between the rule and its interpretation or the rule and its enforcement." 17 Furthermore, ambiguity encourages incremental, endogenous change: "institutional change often occurs precisely when problems of rule interpretation and enforcement open up space for actors to implement existing rules in new ways." 18 This description especially applies to the forces of Drift and Conversion, and it readily describes how Charles II exploited the weakness of the Triennial Act, 1664, as this thesis demonstrates in Section X. Critics of Stephen Harper would perhaps claim that this description applies to him as well.

Thelen and Mahoney identified four means of internal institutional change:

1. Displacement: the removal of existing rules and the introduction of new ones

2. Layering: the introduction of new rules on top of or alongside existing ones

3. Drift: the changed impact of existing rules due to shifts in the environment

4. Conversion: the changed enactment of existing rules due to their strategic redeployment ${ }^{19}$

Displacement and layering clearly differ from one another and are straightforward enough. The former can occur either through violent revolution or through a peaceful change of regime. ${ }^{20}$ Displacement by revolutionary violence corresponds to what other institutionalists call an "exogenous shock". Generally, the "losers" under the old system precipitate the displacement of one regime and substitute it with another. ${ }^{21}$ In contrast, evolutionary political systems like that of the United Kingdom (with some exceptions, like the Glorious Revolution of 1688), Canada, Australia, New Zealand, and the other Commonwealth Realms are characterized more so by layering, which involves incremental change to existing rules by amending, revising, and adding to rules already in existence. ${ }^{22}$ Over time, layering can "change the ways in which the original rules structure behaviour." 23 Sometimes layering can form part of a concerted strategy to displace the existing rules gradually - like the old proverb about boiling a frog by turning up the temperature slowly - or political actors would stumble into significant changes through layering over time without harbouring an intent to alter the institution radically from the outset.

Drift and conversion seem very similar in outcome and can sometimes be difficult to distinguish. The best answer is that external factors cause drift, while the political actors themselves deliberately initiate conversion through their own decisions or by design. According to Mahoney and Thelen, "conversion occurs when rules remain formally the same but are interpreted and enacted in new ways" 24 and when political actors "actively exploit the inherent ambiguities of the institution" and thus drive a wedge into between the formal rules and their substantive application. Drift often stems from neglect or indifference. ${ }^{25}$ Conversion occurs

Two main variables for gradual institutional change include whether the defenders of the status quo exert a strong veto or a weak veto over potential reform, and whether the political actors can exercise wide or narrow discretion in enforcing and interpreting rules. ${ }^{26}$ Thelen and Mahoney also identify four types of change-agents and classify them based on whether they aim to "preserve existing institutional rules" and whether they "abide by the institutional rules" in pursuing their aims. They described the four modes of institutional change as such: ${ }^{27}$ 
Figure 1: Four Modes of Institutional Change and the Four Types of Institutional Reformers

\begin{tabular}{|c|c|c|}
\hline & $\begin{array}{c}\text { Low Discretion in Interpretation and } \\
\text { Enforcement }\end{array}$ & $\begin{array}{c}\text { High Discretion in Interpretation and } \\
\text { Enforcement }\end{array}$ \\
\hline Strong Veto Potential & $\begin{array}{c}\text { Layering } \\
\text { (Subversives) }\end{array}$ & $\begin{array}{c}\text { Drift } \\
\text { (Parasitic Symbionts) }\end{array}$ \\
\hline Weak Veto Potential & $\begin{array}{c}\text { Displacement } \\
\text { (Insurrectionaries) }\end{array}$ & $\begin{array}{c}\text { Conversion } \\
\text { (Opportunists) }\end{array}$ \\
\hline
\end{tabular}

Contrary to the Thelen-Mahoney Model, however, I would submit that Layering and Drift sometimes occur spontaneously as independent or intervening variables and not through the intent of political actors. At the very least, political actors could initiate a process of layering or drift without any end goal in mind, or they could intend but fail to move an institution through Layering or Drift toward a political finality along a particular telos; sometimes fortuna (as Machiavelli described it) or British Prime Minister Harold Macmillan's warning of "events, dear boy, events," can intervene and act almost like an outside veto player.

For example, Responsible Government in the United Kingdom (or "Cabinet Government", as British scholars usually call it) emerged out of Drift. ${ }^{28}$ In the British experience, the "shifting environment" that Thelen and Mahoney associate with Drift came from the Hanoverian Succession in 1714. George I spoke little English, showed little interest in British affairs, and often resided in his native Hanover for six months at a time. He also had a poor relationship with his son, the Prince of Wales who later became George II, so he therefore left the administration of government in his frequent and extended absences to a Regency Council rather naming his son Prince Regent, thus dispersing the exercise of executive authority normally vested in one person to several. ${ }^{29} \mathrm{He}$ rarely attended meetings of the Privy Council even when he was in the United Kingdom. In the political vacuum of George I's salutary neglect, Cabinet, the operative committee of the Privy Council, emerged as the main expression of executive authority. In addition, the Septennial Act, 1715 also provided political stability and secured the Whigs as the pre-dominant political force for most of the $18^{\text {th }}$ century. From 1721 to 1742 , Sir Robert Walpole, First Lord of the Treasury, also emerged as the United Kingdom's first de facto Prime Minister of the practical necessity out of the unitary executive. ${ }^{30}$ In contrast, the grant of Responsible Government to the British North American colonies in the 1840s fits more under Conversion because colonial elites deliberately sought it and petitioned London to provide it. In response to those appeals and to Lord Durham's report on the causes of the Rebellions of 1837, the Colonial Secretary instructed the colonial Governors to implement Responsible Government.

In the context of this student, Canada's fixed-date election laws exemplify layering. The amending formulas of the Constitution of Canada create a strong veto potential which forces reformers to take a gradual or incremental approach. This is not necessarily "subversive" in and of itself, however, but merely an acknowledgement of the realities of the systems in which they operate. As this thesis will show in greater detail later, some Canadian scholars have portrayed the Canadian laws as a form of drift or conversion by grafting onto them a false and confused view of what constitutional conventions are and how they work in conjunction with the written constitution. In contrast, the British Fixed-Term Parliaments Act, 2011 presents a straightforward example of displacement because it has replaced prerogative with statute definitively and clearly, replacing one system with another entirely and neatly. 


\title{
II: How the Varying Sources of Authority of the British Crown and of the Crown of Canada Affect Dissolution
}

\author{
"Prerogative" versus the Authority of the Crown as a Legal Person
}

The literature gives varying definitions of the "prerogative" authority of the Crown. ${ }^{31}$ However, these definitions only provide an accurate description of "prerogative" in the United Kingdom and show that Canadian jurists and scholars ought to re-examine the nature and the sources of the authority of the Crown of Canada.

Prerogatives consist of "a collection of powers, rights, privileges, immunities, and duties" of the Crown. ${ }^{32}$ Peter Hogg defines the prerogative as "the powers and privileges accorded by the common law to the Crown." He continues, "the prerogative is a branch of the common law, because it is the decisions of the courts which have determined its existence and extent." 33 The more precise formulation is that while the courts acknowledge the existence and determine the limit of a prerogative, they do not confer these prerogatives on the Crown. Instead, the courts simply "declare what the royal prerogative is" 34 because the Crown's prerogative authority in fact antedates the judge-made common law and springs from "political custom and the practical power of the King." 35 In other words, the Crown qua Crown inherently and necessarily possesses certain executive authorities. As Hogg points out, the courts cannot recognize new prerogatives. ${ }^{36}$ This truism has led some scholars and jurists to adopt a teleological view that prerogative "falls within a limited and diminishing field." 37 However, as the subsequent analysis demonstrates, the constitutionally entrenched "prerogatives" of the Crown of Canada under sections 9 to 15 of the Constitution Act, 1867 have in fact increased since the grant of Responsible Government in the 1840s, with most of the expansion occurring between 1917 and 1953, as Canada asserted its own separate legal personality and acquired the trappings of sovereignty in defence and external affairs.

British constitutional historian A.V. Dicey, writing in the late $19^{\text {th }}$ century, defined the prerogative as "the residue of discretionary or arbitrary authority, which at any given time is legally left in the hands of the Crown." "38 He added that the prerogative refers to "every act which the executive government can lawfully do without the authority of an act of parliament.",39 Dicey's definition provides what Margit Cohn describes as a "purely descriptive and retrospective" definition of prerogative; it also reflects preferences "for the functional, rather than the historical, basis for judicial analysis of state power [and] for the modern over the archaic." 40 In contrast, English jurist Sir William Blackstone in the $18^{\text {th }}$ century defined "prerogative" more precisely (or, as his critics would no doubt charge, more "narrowly") and differentiated between the authority that the Crown alone possesses from the authority that the Crown possesses by virtue of its status as a corporation sole and thus shares with other legal and natural persons. ${ }^{41}$

\footnotetext{
By the word prerogative, we usually understand that special pre-eminence which the king hath over and above all other persons, and out of the ordinary course of the common law, in right of his regal dignity. It signifies, in its etymology (from prae and rego), something that is required or demanded before, on in preference to, all others. [...] It can be applied to those rights and capacities which the king enjoys alone, in contradistinction to others, and not to those which he enjoys in common with his subjects. ${ }^{42}$
} 
Both British and Canadian courts have rejected Blackstone's definition in favour of Dicey's ${ }^{43}$ and have treated the latter as "functional and modern in emphasizing residuality and parliamentary supremacy." ${ }^{.44}$ Dicey portrays the prerogative authority of the British Crown as an anachronism or an historical relic of a bygone era, when, as British constitutional historian Sebastian Payne shows, it in fact remains "potent," provides most of the executive authority of the British government, ${ }^{45}$ and "remain[s] a constitutional mainstay and a basis for several legal arrangements." ${ }^{, 46}$ Dicey's definition betrays a teleological Whig Progress Narrative, where Parliament legislates prerogative away gradually but by design until it achieves its goal of replacing prerogative authority at Common Law altogether with codified, statutory authority and that nothing can reverse this process. While it is true that Parliament cannot create new prerogatives, historically, the repeal of a statute which formally constrained a prerogative restored said prerogative to its status quo ante. Furthermore, British constitutional historian Robert Craig has also pointed out the flaw in the Dicean Teleology: it also contradicts a key tenet of parliamentary sovereignty: the principle that one parliament cannot bind another. ${ }^{47}$ As such a future parliament could amend or repeal a statute enacted by a previous parliament, including statutes which a put a prerogative into abeyance.

In 1945, First Parliamentary Counsel Sir Granville Ram built upon Blackstone's distinction between "prerogative" and the authorities of the Crown as a person, the latter of which forms "the third source" of the Crown's authority. ${ }^{48}$ In Canada, the Crown's status as a legal person provides the "fourth source" of the Crown's authority. ${ }^{49}$ Under the Ram Doctrine, the Crown "is free to do anything that it is physically capable of doing which is not prohibited by law." ${ }^{, 50}$ More specifically, "the capacities of the crown extend to anything which can be done by a person which is not prohibited or otherwise regulated by law." ${ }^{51}$ This authority "derive[s] from the Crown's status as a corporation sole." 52 In the United Kingdom, the Crown's authorities as a person are limited by both the common law and statute law, ${ }^{53}$ (though prerogative in the Blackstonian sense can supersede common-law rights) ${ }^{54}$ and "are subject to the law of torts." 55 For example, the Crown may enter into contracts by virtue of its authorities as a legal personnot by virtue of a true prerogative. ${ }^{56}$ Unlike the prerogative, which has remained static, but formidable, since the $19^{\text {th }}$ century, the Crown's authorities as a legal person possess an "enormous scope" and, if anything, may broaden in application over time because of "new developments, especially in technology.",57

\section{The Three Sources of Authority of the Crown of the United Kingdom}

In the United Kingdom, the authority of the Crown comes from three sources: prerogative, the Crown as a legal person, and statute. ${ }^{58}$ Since the United Kingdom does not operate under an entrenched, codified constitution, its Parliament can limit, alter, abridge, or put into abeyance any prerogative authority of the Crown at will and replace it with statutory authority. Similarly, Parliament can subsequently restore the prerogative by repealing the statute. Generally, a statute puts a prerogative into abeyance rather than "abrogating" it irrevocably and permanently, as the history of the prerogative of dissolution shows. ${ }^{59}$ If Parliament puts a prerogative into abeyance through statute, the Crown must then act pursuant to the new statutory authority, and no longer through the former prerogative, to the extent that the prerogative has gone into abeyance. ${ }^{60}$ If the statute has not put the full extent of the prerogative into abeyance, then the Crown could still act pursuant to that part of the prerogative. ${ }^{61}$ Conversely, if the British 
Parliament repeals a statute that put a prerogative into abeyance, the prerogative re-emerges if "it is a major government attribute." 62 However, the British Parliament altered this historical principle through section 16 of the Interpretation Act, 1978, which now puts an impediment upon the automatic revival of prerogative through the simple repeal of the offending statute. ${ }^{63}$ But repealing this provision of the Interpretation Act would restore the old system. But the British Parliament can freely widen or limit the authorities and capacities of legal and natural persons and thus the authority that the Crown possesses by virtue of being a legal person. In conclusion, the British Parliament therefore possesses an unfettered power to determine via statute the scope of the prerogative authority of the Crown. This principle also applies in New Zealand, which, like the United Kingdom, also operates on an uncodified constitution. However, this principle does not apply in either Canada or Australia, since both federations operate on hybrid constitutions that consist of codified and uncodified components.

\section{The Four Sources of Authority of the Crown of Canada}

According to Canadian lawyer Paul Lordon, the Crown of Canada derives its authority from four sources and not from three, even though it descends from the Crown of the United Kingdom:

The executive may act pursuant to specific constitutional or statutory authority, pursuant to common law or prerogative authority, or in ways that are purely incidental to the Crown's status as a person or a corporation sole. ${ }^{64}$

More precisely, the Lordon Doctrine breaks down as such:

1. the constitutionally entrenched executive authority contained in sections 9 to 15 of the Constitution Act, 1867 (which corresponds to the prerogative authority in the British system);

2. the other specific provisions of the Constitution Acts and their schedules that confer authorities upon the Crown, or recognize and declare pre-existing authorities thereof;

3. a wide range of statutory authorities that various acts of parliament have delegated to the Governor General or the Governor-in-Council; and ${ }^{65}$

4. the authorities and capacity that the Crown of Canada possesses as a legal person and corporation sole, in common with other legal and natural persons. ${ }^{66}$

Sections 9 to 15 of the Constitution Act, 1867 entrench the first source of the Crown's executive authority within Canada's constitutional system. ${ }^{67}$ Section $52(2)$, the Supremacy Clause of the Constitution Act, 1982, "includes" these authorities within the Constitution of Canada. Section 41(a), which requires a constitutional amendment with respect to the office of the Queen, Governor General and the Lieutenant Governors, further protects this constitutionally entrenched source of authority from statutory encroachment. This first source of authority corresponds to the true "prerogatives" in the United Kingdom and includes such executive functions as the conduct of defence and diplomacy (in as, declaring war, negotiating treaties, recognizing or unrecognizing States) the grant of passports and honours, and the Royal Prerogative of Mercy. In Operation Dismantle, which pertained to executive authority over defence and external affairs, the Supreme Court acknowledged that sections 9 to 15 of the Constitution Act, 1867 vest executive authority in the Queen; the courts therefore "cannot substitute [their] opinion for that of the executive to whom the decision-making power is given 
by the Constitution." 68 The Supreme Court of Canada thereby acknowledges that these authorities of the Crown over defence and external affairs are not merely statutory, but reside within the Constitution of Canada. This case also illustrates that the constitutionally entrenched executive authority of the Crown of Canada has increased since Confederation, contrary to Dicey's teleological narrative that the Crown's prerogatives decrease inexorably over time. I call this the first source of the Crown's authority precisely because it predates the Constitution Act, 1867.

Canadian lawyer Warren J. Newman has argued that section 9 of the Constitution Act, 1867 authorizes "the exercise of the royal prerogative to dissolve or prorogue Parliament." 69 By the authority of section 9 of the Constitution Act, 1867, George VI as King of Canada delegated the authority to summon, prorogue, and dissolve parliament to the Governor General under section 6 of the Letters Patent Constituting the Office of Governor General, 1947 in accordance with Prime Minister Mackenzie King's advice. ${ }^{70}$ These crucial authorities of the Crown thus enjoy a double protection as constitutionally entrenched authority under both section 9 and sections 30 (summoning and prorogation) and 50 (dissolution) of the Constitution Act, 1867; or, as Newman puts it, "The powers to summon, prorogue, and dissolve Parliament flow from the prerogatives of the Crown and the provisions of the Constitution." 71 By "prerogative," Newman in this case is referring to what I call the first source of constitutionally entrenched authority of the Crown of Canada. Section 41(a) of the Constitution Act, 1982 protects "the Office of the Queen, the Governor General and the Lieutenant Governor of a province" from any one legislature alone and ensures that only a constitutional amendment authorized by the House of Commons, Senate, and the ten provincial legislative assemblies can alter them. ${ }^{72}$ Therefore, the Parliament of Canada alone, or a provincial legislature alone, cannot abolish the Crown's authority over dissolution.

These sections of the Constitution Act, 1867 form the core of Responsible Government. ${ }^{73}$ Section 9 shows that the "Executive Government and Authority" of the Crown (at the time of enactment, the one and indivisible Crown of the United Kingdom but post-Statute of Westminster, 1931, to the separate and independent the Crown of Canada) precedes the British North America Act itself, which merely affirms its existence and extent rather than creating this authority:

9. The Executive Government and Authority of and over Canada is hereby declared to continue to be vested in the Queen.

This general executive authority transferred intact from the Province of Canada to the Dominion of Canada in 1867 and includes all the executive authorities that would properly be calling "prerogatives" of the Crown of the United Kingdom; according to Lordon, "the Constitution Act, 1867 did not detract from in form or in any way affect its form and content", though "minor prerogatives that were not essential to the supremacy of the Crown [...] were not necessarily imported to the colonies."74 These minor prerogatives of the British Crown would presumably include those like the Crown's copyright on the King James Bible and ownership of all dolphins in territorial waters. Section 11 established the Privy Council of Canada. By constitutional convention, the Cabinet, a committee of the Privy Council, consists of current Ministers of the Crown and acts as the political executive. Section 13 differentiates the Governor from the 
Governor-in-Council and states that the latter "act[s] by and with the advice of the Queen's Privy Council for Canada."

Various provisions of the Constitution Act, 1867 confer specific authorities on the Governor General and Lieutenant Governors and make up the second source of the Crown of Canada's authority. Section 24 grants the Governor General the authority to "summon qualified persons to the Senate," and section 96 vests the Governor General with the authority to appoint judges. Section 30 states that the Governor General "shall [...] summon and call together the House of Commons." This authority also includes prorogation by necessity, because a parliament can only be summoned "from time to time" (after its initial summoning) if the Governor has previously prorogued it. ${ }^{75}$ Section 50 re-codifies the Crown's authority over dissolution and states that "Every House of Commons shall continue for Five Years from the Day of Return of the Writs for choosing the House (subject to be sooner dissolved by the Governor General), and no longer." Given that the Act of Union, 1841 contained a similar provision, the Constitution Act, 1867 merely reiterated and confirmed this authority. None of these authorities conforms to the Dicean definition of "prerogative" but instead form the second source of the Crown's authority.

In contrast, the third and fourth sources of authority remain within the legislative competence of the Parliament of Canada and the legislatures of the provinces, as per sections 91 and 92 of the Constitution Act, 1867, and thus remain outside the Constitution of Canada as per section 52(2) of the Constitution Act, 1982. The Parliament of Canada or a provincial legislature alone may confer additional delegated statutory authorities on the Crown of Canada, as well as limit, amend, or repeal them. For instance, the third source of authority, delegated legislation, would include Special Warrants, because Parliament created them as a statutory power and can therefore amend, limit, or repeal the same. The fourth source of authority would also remain subject to legislatures and to the courts, because each may widen or limit the authorities and capacities of all legal and natural persons, and thus by extension, the authorities and capacities that the Crown possesses as a legal person. ${ }^{76}$ Since the Crown is a corporation sole, "the Crown (and its servants or agents) [can] do whatever private citizens could do that is not prohibited by law."77

The Queen of Canada and Governor General of Canada exercise the four sources of the Crown's authority on the advice of responsible ministers; the constitutional conventions of Responsible Government thus also form part of the Constitution of Canada. As Newman has argued:

the prerogative and other key executive powers of the Crown contemplated by the law of the Constitution are exercised in accordance with a web on constitutional conventions associated with the principle of responsible government. ${ }^{78}$

This principle applies also to the Crown of Australia. Anne Twomey, an Australian lawyer and Professor of Constitutional Law at the University of Sydney, has shown that the Crown of Australia derives its authorities from the same four sources that Lordon associates with the Crown of Canada:

1. A constitutional provision;

2. Statute;

3. The ancient prerogatives of the Crown; and 
4. The status of the Crown as a person. ${ }^{79}$

Twomey explains that constitutional provisions of the Commonwealth of Australia Constitution Act - such as the Governor General of Australia's authority to appoint judges, prorogue and dissolve Parliament, give Royal Assent, and exercise the Command-in-Chief of the armed forces - necessarily incorporate the constitutional conventions of Responsible Government. Not coincidentally, the Governor General of Canada possesses all these same authorities by virtue of analogous provisions of the Constitution Act, 1867. These constitutional provisions "must be exercised in accordance with the express terms of the Constitution, any implications derived from it, and any constitutional conventions regarding the exercise of such powers. ${ }^{80}$ In other words, the Governor General acts on and (apart from exceptional circumstances) in accordance with the advice of his ministers in exercising the executive authority of the Crown.

The basic principles of Responsible Government thus enjoy constitutional protection in both Canada and Australia. These constitutionally entrenched powers of the Crown remain ultra vires of the Commonwealth Parliament and the state Parliaments. While the Australian parliament could "regulate" the exercise of these authorities, a statute law could neither "remove" nor "substantially restrict" the exercise of such powers. ${ }^{81}$ Philippe Lagassé, Professor of International Affairs and Carleton University, has made the same argument with respect to these constitutionally entrenched sources of authority of the Crown of Canada: legislatures can, at most, only "regulate" them. ${ }^{82}$ This is also the logical extension of Newman's argument on the double entrenchment of the Crown of Canada's authority over dissolution. The courts might one day have to adjudicate on the extent to which parliament or a provincial legislature could regulate a constitutionally entrenched executive authority through statute alone, without fettering a constitutionally entrenched power, versus the type of limitation that would require a constitutional amendment under section 41(a) of the Constitution Act, 1982.

\section{Scholars Recognize Only Two Sources of Authority of the Crown of Canada}

Unfortunately, most Canadian scholars and jurists have limited the sources of authority of the Crown of Canada to two, prerogative and statute, and thus overlooked that the Constitution of Canada has entrenched two of the four sources of authority, as well as the existence of the Ram Doctrine altogether. ${ }^{83}$ They do so by making two fundamental errors: first, in treating the Crown of Canada as identical to the Crown of the United Kingdom; and, second, in adopting Dicey's definition of prerogative over Blackstone's. For example, Hogg et al. note:

It is widely accepted and understood that the powers of the Crown are derived from two sources, statutes and common law. Statutory powers of the Crown are those derived or created by an Act of Parliament. One such statute is the Constitution Act, 1867, an Act of the British Parliament which confers sweeping powers on the Governor General of Canada. ${ }^{84}$

They relegate the Constitution Act, 1867 to a British statute, but later in the same paragraph acknowledge, "the Constitution Act, 1867 [...] as a constitutional statute, can be regarded as falling within a special category." ${ }^{85}$ On the following page, they state, "The Crown has common-law powers that have their source in the royal prerogative." 86 This summary on the Crown of Canada's sources of authority presents numerous conceptual problems. First, while the Constitution Act, 1867 started as an Imperial statute called the British North America Act, 1867, 
the Constitution Acts have since 1982 amounted to the supreme law of Canada, subject to further amendment by Canadian means. Second, as demonstrated, the authorities of the Crown of Canada derive from four sources. Third, what could once have been called the prerogative authority in Canada has been constitutionally entrenched. And even before their entrenchment, the courts recognized existence of the Crown's prerogative authority but did not create it as a branch of the common law.

Canadian jurists have often cited Dicey's definition of "prerogative" and inappropriately applied the British jurisprudence in interpreting the Constitution of Canada. British jurists have widely adopted Dicey's Doctrine on the prerogative authority of the Crown and have often interpreted it teleologically: from this point of view, unstated but implied, the British Parliament could (or should) eventually put the entire prerogative authority into abeyance by replacing them with equivalent statutory authority. Dicey's Doctrine could only apply to the United Kingdom and New Zealand, since they are both unitary states that operate on uncodified and nonentrenched constitutions. Despite the well-recognized separation of powers entrenched in the Constitution of Canada, in Khadr v. Canada (Prime Minister), the Federal Court adopted a facile rendition of Dicey's Doctrine on the prerogative:

The Magna Carta (1215), the Bill of Rights (1688), and the Act of Settlement 1700 were arguably the first steps taken to curtail the absolute powers of the Crown and establish the concept of parliamentary sovereignty. They began a process of restricting the prerogatives of the Crown that continues to the present day. ${ }^{87}$

The Federal Court glossed over the centuries between Magna Carta and the Bill of Rights, as if these two historical events formed the direct and inexorable teleology that would ultimately culminate in the total "exhaustion" of the executive prerogative authority and the permanent destruction of the Crown itself. In short, this is a republican teleology. Thankfully, the true history is both more complex and more interesting. Westminster parliamentarism emerged over centuries through experience, not by design, and any apparent telos only becomes visible in retrospect. ${ }^{88}$ Under Responsible Government, the constitutionally entrenched sources of the executive authority of the Crown have in fact increased since 1867 and proven resilient to both legislative and judicial intervention. ${ }^{89}$

This supposedly inexorable process has not happened. In fact, as the Supreme Court itself recognized in Operation Dismantle, the executive authority of the Crown of Canada has increased since the mid-19 $9^{\text {th }}$ century. Under the misleading heading "Exhaustion of Crown prerogative," the court considered whether the prerogative on passports still existed as a "residual power" - as if Parliament could and should wipe away this conceptually inconvenient "residue" as one would wipe away condensation from a window. ${ }^{90}$ Adopting Dicey's doctrine almost verbatim, the Federal Court defined "the nature of the prerogative as being the residue of discretionary or arbitrary authority left in the hands of the Crown. Without tracing forward from Magna Carta, it is the Crown's powers left over from that which was taken away by Parliament." 91 The Federal Court also adopted Hogg's definition of prerogative as "the powers and privileges accorded by common law to the Crown." 92 It then asserted that Parliament can put any prerogative into abeyance through statute and that this process "has severely curtailed the scope of the Crown prerogative." $" 93$ While the British Parliament can and has followed that process, the Parliament of Canada and the provincial legislatures cannot fetter "prerogatives" of 
the Crown of Canada, which are in fact constitutionally entrenched under the Constitution of Canada as supreme law.

In Black v. Canada, Justice Laskin of the Court of Appeal of Ontario cited Dicey's definition of "prerogative" and then asserted that "the Prime Minister's authority always derive[s] from either a federal statute or the prerogative." "94 As we have seen, the Crown of Canada derives its authority from four sources, not two, and the Prime Minister derives his executive authority and right to tender binding advice from the Governor General's commission to form a government. ${ }^{95}$ The Prime Minister then acts as the Crown's primary constitutional advisor and takes responsibility for the exercise of the Crown's four sources of authority. Likewise, in Conacher, the Federal Court adjudicated on the federal fixed-date election law and the early general federal election of 2008. The Federal Court acknowledged, "the Governor General possesses the power to dissolve Parliament at his or her discretion pursuant to section 50 of the Constitution Act, 1867." "96 The Court then noted that "prerogative powers are subject to judicial review if the exercise of such powers violates Charter rights," 97 that "the Crown prerogative lies within the authority of Parliament," and is thus subject to the Charter, ${ }^{98}$ and that "the power to dissolve Parliament is the Governor General's prerogative." 99 The Court also refers to the Prime Minister's capacity to advise the Governor General to dissolve parliament as a "prerogative.", 100

This are other cases where Canadian courts have not treated the concept of "prerogative" consistently and have ignored the distinction between the four different sources of authority of the Crown. Logically, the Federal Court cannot call the Crown's authority over dissolution a "prerogative" in the Dicean sense because it also acknowledges that the authority derives from section 50 of the Constitution Act, 1867. The Federal Court also acknowledges that prerogative lies within the authority of parliament. Parliament could at most regulate the exercise of dissolution; putting the Crown's authority over dissolution into abeyance remains outside of parliament's authority. The court held that the Prime Minister's advice to the Governor General "is not reviewable" by the courts, even though the court acknowledges that "prerogative" decisions are reviewable and defined dissolution (albeit incorrectly) as a "prerogative." "101 The court concluded that only an amendment under section 41(a) could alter the Governor General's "discretion to dissolve Parliament pursuant to Crown prerogative and section 50." "The whole affair is rather confusing and contradictory, though the Federal Court is at least correct about that last point.

In Conacher, the Government also described dissolution as "a prerogative power of the Governor General," even though earlier in its memorandum, it acknowledged that the Crown's constitutionally entrenched authority over dissolution comes from section 50 of the Constitution Act, 1867 and section 6 of the Letters Patent. ${ }^{103}$ The better wording would be that dissolution is not a "prerogative" in Canada that Parliament or a provincial legislature could wipe away like a mildewy residue but instead a constitutionally entrenched authority subject to the amending formulas of the Constitution of Canada. Dissolution, by the Government's own admission, therefore does not conform to Dicey's definition of "prerogative," which Canadians courts have endorsed at the expense of Blackstone's more accurate definition, because it comes from a provision of the Constitution Act, 1867 - what I earlier called the second source of authority. 
Both the Federal Court and the Government of Canada conflated the Dicean sense of prerogative with a constitutionally entrenched authority.

Dicey's definition of prerogative alludes to a parliamentary deterrence against the Crown, if prerogative refers to "the residue of discretionary and arbitrary authority, which at any given time is legally left in the hands of the Crown." 104 The British Parliament can wield its sovereignty like a sword against the British Crown; even the mere threat of statutory displacement of prerogative authority acts as a deterrent. But in Canada, the Constitution shields the Crown and Parliament from one another and preserves their respective entrenched positions. Unfortunately, the courts' inconsistent use and definition of "prerogative" has produced a series of contradictory rulings. In various rulings, the Courts have referred to both the constitutionally entrenched authority of the Crown and the provisions of the Constitution Acts as "prerogatives" in the Dicean sense. Overall, the courts seem to afford only the latter the protection from statutory encroachment under section 41(a) of the Constitution Act, 1982 and would leave other constitutionally entrenched, though uncodified, authority of the Crown contained in sections 9 to 15 of the Constitution Act, 1867 outside the ambit of "the office of the Queen, the Governor General and Lieutenant Governor of a province" and at the mercy of parliament's jurisdiction under section 91 of the Constitution Act, 1867 and the potential of displacement by statute.

\section{The Entrenchment of the Authority of the Crown and the Separation of Powers}

Some important judicial rulings support the view that section 41(a) of the Constitution Act, 1982 encompasses the powers and authorities of the offices of Queen, Governor General, and the Lieutenant Governors. ${ }^{105}$

The first case resulted from a challenge to Manitoba's Initiative and Referendum Act in 1919. This law allowed the electorate to approve money bills into law directly, by-passing the constitutional authorities of Royal Recommendation and Royal Assent; it thus violated the British North America Act by derogating from the authority of the Lieutenant Governor. ${ }^{106}$ In its ruling Re Initiative and Referendum Act, the Judicial Committee of the Privy Council (JCPC) held that " "the office of Lieutenant-Governor' excludes the making of a law which abrogates any power which the Crown possesses through the Lieutenant-Governor who directly represents the Crown." ${ }^{107}$ From 1867 to 1982, the "office of Lieutenant Governor" fell under section 92 (1) of the British North America Act, 1867, repealed in 1982 and now incorporated instead under section 41(a) of the Constitution Act, 1982. The JCPC declared:

Further, the power to amend the constitution given by s.92, head 1, expressly excepts 'the office of Lieutenant-Governor.' Section 7 of the proposed Act [...] dispensed with the assent of the Lieutenant-Governor provided by ss. 58 and 90 of that Act. [...] The proposed Act also violated the provisions of s. 54 (in conjunction with s. 90 ) as to money bills. ${ }^{108}$

The JCPC concluded that section 92(1) (“office of the Lieutenant Governor") of the British North America Act, 1867 meant that the provincial legislature could not "abrog[ate] any power which the Crown possesses," whether in the Crown's legislative capacity as through Royal Assent or the Crown's executive capacity as through the Royal Recommendation, and thus declared the Referendum and Initiative Act ultra vires to the extent that it "purported to alter the position of the Lieutenant-Governor". 109 
Crucially, in 1985, the Supreme Court of Canada upheld the JCPC's interpretation that "[the office of] the Lieutenant Governor of a province" protects the constitutionally entrenched authorities of the Lieutenant-Governor from statutory encroachment. In Re Manitoba Language Rights, the Supreme Court expressly referred to and building upon the JCPC's ruling from 1919 and held:

\begin{abstract}
Finally, the effort to give legal force and effect to a mere translation of an Act through certification and deposit with the Clerk of the House must fail as an unconstitutional attempt to interfere with the powers of the Lieutenant-Governor. Royal assent is required of all enactments. Section 4(1) purports to do away with royal assent for the translations of Acts, while giving the translations the full force of law. This scheme is clearly ultra vires the province under s. 41(a) of the Constitution Act, 1982. See In re Initiative and Referendum Act, [1919] A.C. 935 (P.C. $)^{110}$
\end{abstract}

If the "office of the Lieutenant Governor" includes the constitutionally entrenched authorities of the office, then so too do the offices of the Queen and Governor General because they all refer to the same Crown of Canada. Indeed, the Supreme Court has taken the position that the "office of Queen, Governor General and Lieutenant Governor of a Province" under section 41(a) includes the powers and authorities of the Crown. ${ }^{111}$ In 2013, the Government of Canada also argued that "office" includes the "powers," "functions," "prerogatives," and "status" of the Crown of Canada. ${ }^{12}$

The "office of the Queen" includes the constitutionally entrenched sources of authority of the Crown of Canada, personified by Queen Elizabeth II and her heirs and successors, and represented by the Governors. ${ }^{113}$ This is why the Parliament of Canada and the nine provincial legislatures that have passed fixed-date election laws have included non-derogation clauses reaffirming and saving the authority of the Governor General and Lieutenant Governors to dissolve their respective legislatures, as per sections 50 and 58 of the Constitution Act, $1867 .{ }^{114}$ Section 41(a) of the Constitution Act, 1982 protects these constitutionally entrenched sources of authority from statutory encroachment.

The Supreme Court of Canada has also supported a doctrine on the separation of powers under the Constitution of Canada, which would provide another defence of the constitutionally entrenched sources of authority of the Crown. Each branch of government must conform to the Constitution, and one part of the Constitution cannot abrogate another. ${ }^{115}$ In New Brunswick Broadcasting, Justice McLaughlin made this oft-cited obiter comment:

Our democratic government consists of several branches: the Crown, as represented by the Governor General and the provincial counterparts of that office; the legislative body; the executive; and the courts. It is fundamental to the working of government as a whole that all these parts play their proper role. It is equally fundamental that no one of them overstep its bounds, that each show proper deference for the legitimate sphere of activity of the other. ${ }^{116}$

The Supreme Court re-affirmed this doctrine of the separation of powers relating to judicial independence and parliamentary privilege in subsequent cases. ${ }^{117}$ Therefore, the executive authority ought to enjoy a comparable constitutional protection under this doctrine. Dale Gibson, Professor Emeritus of Law at the University of Manitoba, and Philippe Lagassé have also proposed this framework of constitutionally entrenched executive, legislative, and judicial authorities. ${ }^{118}$ The court's doctrine on the separation of powers reinforces the argument 
that Parliament alone cannot alter or abridge the two constitutionally entrenched the sources of the Crown's authority.

Analysis of the Sources on Authority of the British and Canadian Crowns and the Nature of Dissolution

Unfettered parliamentary supremacy along the English, and later British, model has never existed in British North America or in the Dominion of Canada. ${ }^{119}$ Instead, Canada has developed along the lines of constitutional supremacy. ${ }^{120}$ From the Constitutional Act, 1791 through the Act of Union, 1841, Upper and Lower Canada and the United Province of Canada, as Crown colonies, enjoyed varying degrees of self-government and Responsible Government only in their internal affairs and were still subject to the jurisdiction of the Imperial Parliament in London, particularly in matters of defence and foreign policy. The same principle applied to the Atlantic and Pacific Crown colonies. The British North America Act, 1867 re-organized the Crown colonies of British North America into a federal union. From 1867 until roughly 1931, the combination of Imperial jurisdiction over defence and external affairs and the federalprovincial division of powers again ensured that unfettered parliamentary supremacy never existed. Between 1931 and 1982, the Parliament of Canada or the provincial legislatures alone could not unilaterally amend certain parts of the Constitution. Section 7(1) of the Statute of Westminster, 1931 saved the British North America Act as British statute, which meant that only the British Parliament could amend it on the advice of a joint address of the House of Commons and Senate, and/or at the request and with the consent of the Government of Canada through an Order-in-Council. $^{121}$

Canada finally patriated the British North America Act in 1982 and added a bill of rights and an amending formula to the Constitution. That patriated amending formula and section 52 (2) of the Constitution Act, 1982 constitutionally entrenched the "Office of Queen, Governor General or Lieutenant Governor of a Province." "122 According to Barry Strayer, a former Assistant Deputy Attorney General heavily involved in Patriation, section 52(2) of the Constitution Act, 1982 "maintain[ed] the continuity of our system" by "reaffirming the constitutional supremacy principle" that before 1982 resided in section 7(1) of the Statute of Westminster and section 2 of the Colonial Laws Validity Act. ${ }^{123}$ The two constitutionally entrenched sources of authority of the Crown of Canada are not wholly "within the authority of Parliament" nor "within the authority of the legislature of each province"; instead, these constitutionally entrenched sources of authority fall under the "the office of the Queen, the Governor General and the Lieutenant Governor of a Province" under section 41(a) of the Constitution Act, 1982 and thus form part of the Constitution of Canada under section 52(2) of the same. In these cases, the "office" encompasses the powers, authorities, privileges, and immunities of the Queen, Governor General, and Lieutenant Governors because the Crown is a corporation sole. $^{124}$

The Constitution Act, 1867 entrenched most of the "prerogatives" of the Crown in Canada and subjected them to constitutional supremacy, while the prerogative authority of the Crown of the United Kingdom remain subject to the supremacy of the British Parliament. Moreover, if "prerogatives" refer to the authorities that the courts have recognized as belonging to the Crown at common law, then various authorities of the Crown of Canada - including 
prorogation and dissolution - could not properly be called prerogatives. Whether jurists and scholars refer to dissolution as a "prerogative" or by another name, the Crown's authority over dissolution forms part of the Constitution of Canada under the supremacy clause of section 52 (2) of the Constitution Act, 1982, and they are subject to amendment under section41 (a) of the same. It is high time that Canadian jurists and scholars acknowledge that Dicey's definition of the prerogative, and its implied teleology, do not apply to the constitutionally entrenched sources of authority of the Crown of Canada. The extent to which the Parliament of Canada and the provincial legislatures can legislate with respect to the constitutionally entrenched authorities of the Crown, such as dissolution, depends upon this understanding.

\section{III: The Constitution of Canada and the Political Cynicism of Evading Constitutional Amendment}

\section{The Nature of the Constitution of Canada}

The nature of the Constitution of Canada itself, which consists of both codified and uncodified components, shows why the legislatures could not bind the First Minister without necessarily also binding the Governor. In 1917, William Renwick Riddell, then a Justice of the Supreme Court of Ontario, explained to an American audience the differences between the classical, or English, versus the modern, or American, concept of the "constitution." He described "the constitution, in the English sense" as "the totality of the principles more or less vaguely and generally stated upon which we think the people should be governed," while the "constitution in the American sense" refers to "a written document [...] which authoritatively and without appeal dictates what shall and what shall not be done." ${ }^{25}$ Riddell added that under the "constitution in the English sense," an action could be legal but unconstitutional, while in the American sense, that which is unconstitutional is also necessarily illegal. ${ }^{126}$

The classical and British view of the constitution ultimately derives from the Ancient Greeks' idea of nomos, often ambiguously translated as "law." Nomos refers to the sum total of human conventions, customs, norms through which the citizens of a polis govern themselves, as well as to "the tradition of law", or the rule of law itself, and not merely to written statute laws. ${ }^{127}$ In contrast, constitution in the American sense comes from the Enlightenment tradition of the late $18^{\text {th }}$ century and did much to shape the word as generally understood today. Codifying a constitution as supreme law - a radical act in and of itself - rejected the Bodinian-Blackstonian idea of sovereignty and allowed the United States to set up a division of powers between two orders of government and replace legislative sovereignty with a popular sovereignty from which both orders of government flow. ${ }^{128}$ Canada and Australia later drew federalism from the American experience but did not adopt the US system entirely. The Constitution of Canada relies on parliamentary co-sovereignty of two orders of government; the five amending procedures reflect the paramountcy of legislative bodies, while the Constitution of Australia's doublemajority amending procedure draws more from American conceptions of popular sovereignty.

The Supreme Court of Canada combined the two conceptions of the constitution in the Patriation Reference in 1981 and later re-affirmed it in the Secession Reference in 1998 and again in the Senate Reform Reference in 2014, thus acknowledging that this dual conception of 
the Constitution of Canada applies after the entrenchment of the Constitution Act, $1982 .{ }^{129}$ The Supreme Court declared in the Patriation Reference:

the phrases 'Constitution of Canada' and 'Canadian Constitution' [...] embrace the global system of rules and principles which govern the exercise of constitutional authority in the whole and every part of the Canadian state. ${ }^{130}[\ldots]$

[C]onstitutional conventions plus constitutional law equal the total constitution of the country. ${ }^{131}$

However, the Supreme Court broke down the "Constitution of Canada" into separate categories and differentiated between the "law of the constitution," which are justiciable and on which the courts can adjudicate, and the "rules of the constitution" or "requirements of the constitution," which are not justiciable but are instead politically enforceable. The two categories correspond to what Riddell called the American and English conceptions of the "constitution." The courts should therefore, at least in theory, only acknowledge the existence of a constitutional convention, but they could not attempt to enforce a judicial remedy in response to the violation of a constitutional convention. ${ }^{132}$ For instance, the Federal Court ruled in Conacher that "votes of non-confidence are political in nature and lack legal aspects" and that therefore the Prime Minister, not the courts, would judge whether the Government had lost the confidence of the Commons. ${ }^{133}$ The Supreme Court classified the constitutional conventions associated with Responsible Government - such as the confidence convention - under the latter, non-justiciable category of "rules of the constitution." "134 The Supreme Court thus seems to have established two orders of the Constitution of Canada in which the "law of the constitution" ultimately trumps the "essential rules of the constitution" - if only because the courts cannot enforce the latter category. ${ }^{135}$ In the Senate Reform Reference, the Supreme Court refers to the "constitutional architecture" underpinning the Constitution Acts in a manner similar to the "rules of the constitution" and what Riddell called the constitution in the British sense.

The Supreme Court also concluded:

[W]hile they are not laws, some conventions may be more important than some laws. Their importance depends on that of the value or principle which they are meant to safeguard. Also they form an integral part of the constitution and of the constitutional system. [...]. That is why it is perfectly appropriate to say that to violate a convention is to do something which is unconstitutional although it entails no direct legal consequence [emphasis added]. ${ }^{136}$

The SCC re-affirmed and expanded upon this principle in the Secession Reference:

The Constitution is more than a written text. It embraces the entire global system of rules and principles which govern the exercise of constitutional authority. A superficial reading of selected provisions of the written constitutional enactment, without more, may be misleading. ${ }^{137}$

In 2014, the Supreme Court of Canada again re-affirmed and built upon this doctrine on the nature of the Constitution of Canada and the separation of powers that it entails in the Senate Reform Reference:

The Constitution of Canada is a comprehensive set of rules and principles that provides an exhaustive legal framework for our system of government. It defines the powers of the constituent elements of Canada's system of government - the executive, the legislatures, and the courts - as well as the division of powers between the federal and provincial governments. ${ }^{138}[\ldots]$ 
The Constitution implements a structure of government and must be understood by reference to "the constitutional text itself, the historical context, and previous judicial interpretations of constitutional meaning." [...] The rules of constitutional interpretation require that constitutional documents be interpreted in a broad and purposive manner and placed in their proper linguistic, philosophic, and historical contexts. ${ }^{139}[\ldots]$ The assumptions that underlie the text and the manner in which the constitutional provisions are intended to interact with one another must inform our interpretation, understanding, and application of the text. ${ }^{140}$

The Supreme Court of Canada also acknowledged in the Secession Reference that the Supremacy Clause, section 52(2) of the Constitution Act, 1982, is not exhaustive and therefore "includes" statutes not enumerated in the schedule, as well as constitutional principles and conventions. The Supreme Court of Canada reaffirmed this ruling in the Senate Reform Reference of 2014.

The 'Constitution of Canada' certainly includes the constitutional texts enumerated in s. 52(2) of the Constitution Act, 1982. Although these texts have a primary place in determining constitutional rules, they are not exhaustive. [...] These supporting principles and rules, which include constitutional conventions and the workings of Parliament, are a necessary part of our Constitution because problems or situations may arise which are not expressly dealt with by the text of the Constitution. In order to endure over time, a constitution must contain a comprehensive set of rules and principles which are capable of providing an exhaustive legal framework for our system of government. ${ }^{141}$

Section 52 does not provide an exhaustive definition of the content of the Constitution of Canada. ${ }^{142}$

In other words, a literal reading of the Constitution Act, 1867 would be profoundly misleading. Such a literal reading would mean that the Queen and Governor General act not merely as the executive authority and promulgate the advice of responsible Ministers of the Crown, but that they impose a personal rule like a Stuart King. ${ }^{143}$ The Constitution of Canada thus "includes" both the formal constitutional provisions and the informal constitutional conventions under section 52 of the Constitution Act, 1982. Only the combination of the formal and informal yields a statement that is both legally true and constitutionally accurate. ${ }^{144}$ The literal reading of the Constitution Act that the Governor General promulgates all acts of the Crown is true but misleading. The converse that "the powers of the royal prerogative are exercised, in reality, by the federal and provincial governments" - as a Quebec court ruled sounds politically palatable but is also misleading, because the Crown, as personified by the Queen and represented by the Governor General and Lieutenant-Governors, still holds these authorities and formally promulgates them in accordance with ministerial advice. ${ }^{145}$

The true and accurate formulation would take into account the democratic principle, which manifests itself through Responsible Government. Responsible Government means that "Ministers of the Crown take responsibility of all acts of the Crown"146 and that the Governor General acts on and in accordance with ministerial advice, ${ }^{147}$ save for exceptional

circumstances. ${ }^{148}$ Even in the exceptional case where advice is refused, a Governor who rejects a First Minister's advice would dismiss him or her and appoint a new First Minister who would take responsibility for that dismissal. ${ }^{149}$ Parliament therefore cannot limit the First Minister's discretion to advise and take responsibility for dissolution without also necessarily limiting how the Governor promulgates that advice; the Governor and First Minister form a chain of authority 
and ultimately both derive their commissions from the Queen. ${ }^{150}$ This formulation combines the written, legal, and formal with the uncodified, constitutional, and informal.

The Patriation of the Constitution in 1982 ensured that the conventions of Responsible Government form part of the Constitution of Canada under section 52(2); they are therefore subject to amendment under section 41(a) of the Constitution Act, 1982 because they pertain to the Crown. ${ }^{151}$ If the Constitution of Canada did not include these principles of Responsible Government, which are associated with the constitutionally entrenched first source of authority under sections 9 to 15 of the Constitution Act, 1867 and how they are exercised, then Parliament and the provincial legislatures could subvert democratic government by driving a wedge between the First Minister and Governor and violate the democratic principle that the Supreme Court identified in the Secession Reference. While the courts cannot enforce constitutional conventions pertaining to Responsible Government, the constitutional relationship between the First Minister and Governor still forms part of the constitution and is an inextricable link that legislatures cannot separate through statute.

As I demonstrate Part VII, this jurisprudence had bearing on the Conacher cases and the issue of how the Federal Court and Federal Court of Appeal adjudicated on whether the federal fixed-date election law had created a constitutional convention, and whether the courts could somehow remedy a breach of constitutional convention.

\section{How the Constitution of Canada Limits the Scope of Fixed-Date Election Laws}

In order to understand why Canadian politicians and legislative drafters included nonderogation clauses in the various federal and provincial fixed-date election laws specifically in order to prevent the possibility of a constitutional amendment, thereby preserving the status quo, we must first take into account the origins of the fear and paralysis that seizes up any possibility of serious constitutional amendment in Canada.

The central problematic of $20^{\text {th }}$-century Canadian political history hinged upon one fateful decision from the 1860s which seemed insignificant at the time: the British North America Act did not delegate to the Dominion of Canada the means of amending this Imperial statute on its own through an indigenous amending formula. (It also exemplifies the tension between two types of institutional change that Thelen and Mahoney identified: layering and displacement). Instead, the Imperial Parliament itself would continue to amend this Imperial statute as required. The Statue of Westminster could have solved this question in December 1931, but for the fact that Canada's First Ministers could not agree to new system in time. So they decided at a Dominion-Provincial Conference in April 1931 to continue the status quo and default to allowing the Imperial Parliament to continue amending Canada's de facto constitution. Instead, another fifty years passed before Prime Minister Pierre Trudeau spearheaded the "patriation" of the British North America Act, 1867. The Imperial Parliament thus legislated for Canada one last time and forsook its authority to do so ever again through the Canada Act, 1982, which in Canada became the Constitution Act, 1982. This action "patriated" the Constitution of Canada and included a series of five amending formulas which now allow Canadian legislative bodies to amend it without any further British involvement. 
The "Constitution of Canada" consists of a non-exhaustive mixture of codified elements - the Constitution Acts, 1867-1982 themselves, the 30 British and Canadian statutes and executive instruments in its schedule, and other non-enumerated statutes - and uncodified constitutional conventions and constitutional principles. ${ }^{152}$ Part V of the Constitution Act, 1982 outlines the five classes of amending formulas, the subject-matter and constitutional provisions to which each applies, and two methods (resolution and proclamation on the one hand or statute on the other) by which these amendments are promulgated. ${ }^{153}$ Together, these amending formulas cover any and all amendments to the text of the Constitution Acts - they are exhaustive. ${ }^{154}$ Part V of the Constitution Act, 1982 represents the culmination of fifty years of political struggle "to become constitutionally self-governing," as Canadian political historian Peter Russell states, ${ }^{155}$ re-affirm Canadian sovereignty and independence, and bring the promise of autonomy underpinning the Balfour Declaration and the Statute of Westminster to their logical conclusion. ${ }^{156}$

The General Amending Formula, outlined in section 38 as the default formula and again in some specific cases in section 42, requires concurring resolutions from the House of Commons and Senate and at least 7 provincial assemblies which combined represent at least onehalf of Canada's population. The Unanimity Formula requires concurring resolutions from all 10 provincial legislatures and the House of Commons and Senate. The Section 43 Formula applies to matters that affect some but not all ten provinces and involves concurring resolutions by the House of Commons, Senate, and the legislative assemblies of the provinces concerned. These three "multilateral procedures," which rely on concurring resolutions of legislative bodies and not acts of Parliament or a provincial legislature, are then promulgated into force through a proclamation issued by the Governor General on the advice of cabinet. ${ }^{157}$ The Section 44 Formula allows the Parliament of Canada alone, through a normal statute, to amend the constitution "in relation to the executive government of Canada or the Senate and House of Commons", and the Section 45 Formula likewise allows the provincial legislatures to "exclusively make laws amending the constitution of the province" by statute. ${ }^{158}$ These statutory formulas derive directly from the now-defunct and repealed sections 91(1) and 92(1) of the British North America Act, $1867 .{ }^{159}$

The Parliament of Canada has always been competent to enact what Newman and other scholars call variously "quasi-constitutional statutes" or "organic statutes," which flesh out the bare bones of the Constitution Acts by providing for the fundamental executive, legislative, and judicial institutions of the State, under the Peace, Order, and Good Government Clause of section 91 of the Constitution Act, $1867 .{ }^{160}$ A similar principle likewise applies to the provinces. Provincial legislatures alone can amend certain provisions of the Constitution Acts and the legislation and executive instruments in their schedules under the Section 45 Amending Formula, and they can enact, amend, and repeal organic provincial statutes under the authority of Section 92(16) of the Constitution Act, 1867. This latter method where amending quasi-constitutional organic statutes can stand in for formal constitutional amendments under Sections 44 or 45 probably best describes the nature of the fixed-date elections provision in Canada Elections Act and the various provincial Election Acts and Legislative Assembly and Executive Council Acts.

Since the failure of Meech Lake and Charlottetown Accords in 1987 and 1992, respectively, ${ }^{161}$ the spectre of "Opening the Constitution" has struck fear in the hearts of 
Canadian politicians and has become shorthand for expressing the political futility and foolishness - made so by the high veto potential of the provinces - of amending the constitution under either the General Amending Formula or the Unanimity Formula. These three little words, "Opening the Constitution", and the apocalyptic hyperbole to which they allude, have become so imbued with the mysterious power of legend and folklore and no doubt deliberately allude to “opening Pandora's Box." Speak this incantation, and you can stop potential reform dead in its tracks - especially in light of the Supreme Court Reference and Senate Reform Reference of 2014. Like the Ancient Greek myth from which it flows, "Opening the Constitution" serves as a cautionary tale.

The Canadian model of fixed-date elections emerged from this obsession over avoiding serious constitutional amendment and the constitutional scoliosis which has set in since the mid1990s. As the Thelen-Mahoney Model suggests, Layering (potentially advocated by Subversives) becomes the best option for institutional change because the Unanimity Formula and General Amending Formula require such high thresholds for amending the Constitution of Canada and therefore turn provincial governments and legislatures into strong veto players. And Canadian political history has shown that the provinces wield their vetos with gusto and sometimes even gleefully suspend them over Ottawa like the Sword of Damocles. Interestingly, this means that an early, failed push toward fixed-date election laws in the 1970s, before Patriation and the establishment of the amending formulas to the Constitution of Canada in 1982, could have succeeded more easily in imposing true restrictions on the Crown of Canada's authority over dissolution.

\section{IV: Responsible Government: What It Means and How It Works}

\section{The Established Constitutional Positions of the Crown and Ministers of the Crown}

Under Canada's constitutional monarchy, the Queen appoints the Governor General upon the advice of the Prime Minister, and the Governor General and Prime Minister both derive their executive authority from the Crown. The Governor General appoints the Prime Minister based on the authority that the Letters Patent have delegated to him $^{162}$, and the Prime Minister and ministry as a whole take responsibility for all acts of the Crown, which are promulgated in the name of the Queen. ${ }^{163}$ The tenure, or term in office, of the Prime Minister determines the tenure of the ministry as a whole; therefore, the Prime Minister's resignation automatically entails the resignation of the ministry as a whole. ${ }^{164}$ The Governor General's authority over forming governments and dissolving parliaments is paramount. This is because the first duty of the Governor General is to ensure that there is always a duly-appointed ministry in office so that the Queen's business always carries on. ${ }^{165}$ Just as there must always a Sovereign, there must always be a ministry in office that can take responsibility for all acts carried out in the Sovereign's name.

At its core, Responsible Government is a trinity (three in one) of responsibilities: ministerial responsibility to the Crown, individual ministerial responsibility before the Commons, and collective ministerial responsibility and solidarity before the Commons. ${ }^{166}$ The Government must command the confidence of both the Governor, who grants ministers the authority to govern under the Crown, and of the legislative assembly, which must either pass 
supply or else force either the government's resignation or dissolution and fresh elections. The Prime Minister and ministry first receive their official commission of authority to form government from the Crown, and they must later demonstrate that they command the confidence of the elected assembly. However, the Prime Minister and ministry generally first lose of the confidence of the elected assembly; apart from the most exceptional circumstances, the Governor General would not withdraw his confidence from the Prime Minister and ministry, by refusing to promulgate their advice, unless the elected assembly had already withdrawn its confidence from the ministry in a formal vote in the chamber.

And in practice, Responsible Government means that "Ministers of the Crown take responsibility for all acts of the Crown" and that the Governor General acts on and in accordance with ministerial advice, save for exceptional circumstances, which in turn ensures the partisan neutrality of the Crown that he represents. ${ }^{167}$ These acts include accepting responsibility for one's own appointment as Prime Minister, the dismissal of one's predecessor, and for summoning, proroguing, and dissolving parliament. Ultimately, this arrangement ensures balance; Responsible Government guarantees that one Prime Minister and Ministry or another will always take responsibility for all acts of the Crown before the Commons and the electorate. In so doing, this system secures the principles of democracy and accountability. Under Responsible Government, defending the political neutrality of the Sovereign or Governor and taking responsibility for all acts of the Crown are one and the same. ${ }^{168}$

The Governor General can only refuse to promulgate ministerial advice in exceptional circumstances because the consequence of exercising such discretionary authority is equally and proportionately exceptional: the Governor General thereby dismisses the Prime Minister and ministry which tendered the original constitutional advice and must appoint in their place a new Prime Minister and ministry which can then take responsibility for his decision to refuse advice and force the dismissal of their predecessors. ${ }^{169}$ For example, if the Governor General refused to promulgate the Prime Minister's advice to dissolve parliament, he would in so doing withdraw also his confidence from the Prime Minister and revoke his authority to govern. At that stage, the Governor General would then have to appoint a new Prime Minister and ministry who could take responsibility for these acts of the Crown (refusing the dissolution and dismissing the previous ministry), because a ministry can only take responsibility for advice that it has offered, not for the contrary advice that it did not offer. ${ }^{170}$ In principle, the Governor General could refuse to implement one Prime Minister's advice to dissolve parliament if there were a viable alternative government that could gain the confidence of the existing parliament, and if that alternative government were also willing to take the responsibility for the dismissal of its predecessor. This occurred in the Province of Canada in 1858, the Dominion of Canada in 1926, the Province of Ontario in 1985, and the Province of British Columbia in 2017. However, no Governor General or Lieutenant Governor has ever refused to promulgate a Prime Minister's advice to prorogue parliament.

Finally, refusing advice to dissolve is not the equivalent of dissolving unilaterally. Under our system, Governors do not and cannot undertake any executive act unilaterally because every proclamation, Order-in-Council, or other executive instruments requires the counter-signature of a responsible Minister of the Crown before the Governor can formally promulgate it, as the Seals Act indicates. ${ }^{171}$ As such, the proclamations of dissolution, the writs of election, and calling 
together the next parliament after the general election all require the counter-signatures of responsible ministers of the Crown or deputy ministers who are responsible to ministers of the Crown, before the Governor General can validly promulgate them into force.

Aucoin, Jarvis, and Turnbull's work contains this fundamental flaw: they draw a false distinction between "the discretionary powers assigned to the Governor General but regularly exercised virtually unilaterally by the Prime Minister" on the one hand and "other executive powers assigned to Prime Ministers" on the other. ${ }^{172}$ From this false premise, they draw the false conclusion that they could somehow both preserve the principles of Responsible Government and separate the Governor General's promulgation of executive authority from the Prime Minister's advice. In reality, all executive authority flows from the Queen as per section 9 of the Constitution Act, 1867, and all executive authority is exercised by the Queen or Governor General on the advice of the Prime Minister alone or cabinet as a committee of the Privy Council. The Constitution of Canada includes both the Constitution Acts and the constitutional conventions of Responsible Government. Logically, Parliament therefore cannot drive a wedge between the Governor General, who carries out advice in the Queen's name, and the Prime Minister, who advises the Governor General and derives his commission of authority to govern from him, or otherwise attempt to draw a false distinction between the two, because under no circumstances could the Governor General act independent of ministerial advice on matters of state, and only under the aforementioned exceptional circumstances could the Governor General act contrary to ministerial advice.

Even before the constitutional entrenchment of the first and second sources of authority through the Constitution Act, 1982, the prerogatives of the Crown had not diminished inexorably over time; they reached a natural equilibrium during the mid- $19^{\text {th }}$ century and then increased in the $20^{\text {th }}$ century as Canada gradually took on the trappings of an independent, sovereign state with its separate Crown, precisely because Responsible Government reconciled the medieval political doctrine that "the King can do no wrong" within a modern liberal-democratic framework. ${ }^{173}$ Since Ministers of the Crown take responsibility for all acts of the Crown, and the Sovereign, or Governor, acts on the advice of Ministers, the Sovereign can still do no wrong only Ministers responsible to Parliament and to the people can do wrong. In other words, Responsible Government legitimated the prerogative authority of the Crown by harnessing it to democratic principles and thus guaranteed its survival. Far from the anachronism or latent despotism that the republican teleology derides, Responsible Government has made the Crown the protector of liberty, democracy, and the rule of law in the modern era.

\section{How the Constitution Act, 1867 Partially Codifies Responsible Government}

The Constitution Act, 1867 partially codifies these basic principles of Responsible Government. ${ }^{174}$ Section 10 states that the Governor General acts "on behalf of and in the name of the Queen," section 12 states that the Governor General acts alone (thus, conventionally, on the Prime Minister's advice) or on the advice of the Privy Council (thus, conventionally, on the Cabinet's advice), and section 13 further clarifies that the Governor-in-Council refers to "the Governor General acting by and with the advice of the Queen's Privy Council for Canada" (and thus, conventionally, on the advice of Cabinet). 
Where the Constitution Acts mention the Governor General, the Prime Minister by convention tenders and takes responsibility for that advice; where they mention the Governor-inCouncil, the cabinet collectively tenders advice and takes responsibility for those acts of the Crown. Combining the written constitution with the conventions of Responsible Government, we derive the following formulation: the Governor General summons, prorogues, and dissolves Parliament on and in accordance with the advice of the Prime Minister. Where the Constitution Act, 1867 confers an authority upon the Queen of Canada or the Governor General, by convention, the Prime Minister tenders and takes responsibility for that advice; where it vests an authority in the Governor-in-Council, the Cabinet collectively tenders advice and takes responsibility. The Constitution Act, 1867 confers the authority over the summoning, prorogation, and dissolution of parliament on the Governor General, and the Prime Minister alone therefore advises the Governor General to promulgate these executive acts. Even the different types of executive instruments which Canadian Ministers of the Crown employ illustrate this distinction: Cabinet, with a quorum of at least four Privy Councillors, advises the Governor General via an Order-in-Council, while the Prime Minister alone advises the Governor General through an Instrument of Advice. ${ }^{175}$

Responsible Government is all about the money: who proposes taxation and spending (the executive), who approves taxation and spending (the legislature), and who takes responsibility for taxation and spending (the executive). The Origination Principle and the Royal Recommendation, contained in sections 53 and 54 of the Constitution Act, 1867, respectively, are necessary conditions for Responsible Government itself and the narrow separation of powers between the executive and legislature that this system entails. ${ }^{176}$ The Origination Principle guarantees that only the people's elected representatives in the House of Commons can introduce bills that would levy tax or grant expenditures; the Royal Recommendation, which the Governor General grants on and in accordance with ministerial advice, means that the Ministry must take responsibility for, and therefore give sanction to, all money bills.

53. Bills for appropriating any Part of the Public Revenue, or for imposing any Tax or Impost, shall originate in the House of Commons.

54. It shall not be lawful for the House of Commons to adopt or pass any Vote, Resolution, Address, or Bill for the Appropriation of any Part of the Public Revenue, or of any Tax or Impost, to any Purpose that has not been first recommended to that House by Message of the Governor General in the Session in which such Vote, Resolution, Address, or Bill is proposed.

In his famous (or infamous) report, Lord Durham recommended adopting the Royal Recommendation as the antidote to what he called "tacking," the practice through which individual MPs with the legislatures of Upper Canada and Lower Canada proposed capital expenditures which benefited mostly or solely their own constituencies. Durham referred to the Original Principle and Royal Recommendation as "the real protection of the people" because this tandem ensures that parliament only approves appropriations which have the support of a majority of elected MPs, and thus those who represent the majority of the people. ${ }^{177}$ The Royal Recommendation thus also ties neatly into George Brown's crusade for Representation by Population within the House of Commons: the most populous provinces which contribute the most tax revenue would exert the most influence over expenditure. Finally, the Royal Recommendation also enshrines classical liberal principles of good government by inextricably linking taxation, representation, and expenditure together. 
Without the Royal Recommendation, a collection of individual members could introduce an eclectic and incoherent mix of spending proposals - and worse still, would not have to take responsibility for them. This is precisely what happened in the Canadas prior to the grant of Responsible Government on the recommendation of Lord Durham. Without the Royal Recommendation, the assembly could not hold the government responsible for all financial decisions nor withdraw its confidence from the Government by refusing to grant supply. ${ }^{178}$ The Royal Recommendation thus "denies the legislative branch a policy-making function" and ensures that members of parliament instead "monitor, evaluate, judge and decide on the proposals, policies and actions of 'the Government' on behalf of the people whom they represent." ",179

Consequently, the Royal Recommendation sets up the ideal relationship between the Government and Opposition under Responsible Government in contrast to the relationship between King and Commons or Cabinet and Commons under the Balanced Constitution of the $18^{\text {th }}$ century in the United Kingdom and that between the Governor and legislative assembly in British North America from 1791 to 1841. Under the Balanced Constitution and Representative Government, the Commons could defend itself only by reducing and curtailing the powers of the Crown through statute law; under Responsible Government, however, the Opposition presents itself as an alternative Government and seeks to replace the Government by proposing a different set of policies. The Opposition thus does not need to resort to reducing the powers of the Crown, but instead strives to replace the Government so that it can then exercise the powers of the Crown. The push for fixed-date election laws reverses the normal dynamic of Responsible Government and harkens back to an earlier era.

From sections 53 and 54 flow other key aspects of Responsible Government. The House of Commons cannot force the Government to spend money on projects for which it refuses to take responsibility; instead, the House of Commons would have to withdraw its confidence in the Government, and the Opposition would attempt to form an alternate government or force fresh elections and take its case to the people. The assembly does not itself govern; the assembly chooses who governs by expressing its confidence, or want of confidence, in Cabinet. Canadian political scientist Dennis Baker argues that sections 53 and 54 must be regarded as "inseparable and complementary." "They ensure that "the Commons may reject the Cabinet's tax and spending plans but that they may not initiate their own," and that in turn, "Cabinet can propose a cohesive plan but cannot enact it without the approval of the people's representatives." "181 Section 54 "makes 'budgeting' possible" in the first place because Cabinet must take collective ministerial responsibility for all proposed spending and can then present a "coherent program of taxing and spending legislation." 182 These sections mandate the "partial agency" of the political executive and the legislature in the other's affairs and the balance of Responsible Government between the Cabinet and Commons. ${ }^{183}$

Responsible Government also makes prolonged deadlock over a budget impossible. Either the Ministry would succeed in shepherding their appropriations bills - for which they take responsibility through the Royal Recommendation - through the House of Commons, or the House of Commons would defeat these money bills, thereby withdrawing its confidence from the Ministry, and forcing the Prime Minister either to advise dissolution and fresh elections or, in some hung parliaments, to resign and make way for a new ministry immediately. ${ }^{184}$ Good 
government fundamentally depends upon a strong link between taxation, representation, and expenditure, which bind together the accountability and responsibility of the government and the consent of the governed. ${ }^{185}$ Political scientists know what happens when that relationship breaks down: many petro-States are authoritarian precisely because the government can rely on royalties from natural resources for revenue rather than having to rely on taxation taken from the people. Consent and accountability break down because the people have no stake in the government. Classical liberals like Lord Durham well understood this principle.

\section{Commanding Confidence of the Crown and of the Commons}

Like Responsible Government itself, the Confidence Convention consists of more than the ability of the ministry to command a majority in the Commons. First, the Governor General expresses confidence in the Prime Minister by appointing him and granting him an official commission of authority to govern, which allows him to form a ministry. Second, the Commons either confirms that it also holds confidence in the ministry, or it expresses non-confidence in the ministry. Once the ministry has demonstrated that it commands the confidence of the Commons, it continues to hold that confidence until the moment that the Commons decides to withdraw it from the ministry. ${ }^{186}$ Generally, the Address in the Reply to the Speech from the Throne acts as the first de facto confidence measure in a new session of parliament. That said, the ministry can also judge when it has lost the confidence of the Commons, such as by deeming a bill or motion a matter of confidence and then losing a vote on it, or, more generally, if it has lost the ability to control the agenda of the Commons. ${ }^{187}$

Sometimes the ministry's command of the confidence of the Commons is a sufficient condition and not a necessary condition. Logically, it cannot possibly be true that the ministry always commands the confidence of the Commons - because sometimes the Commons does not exist (as in when Parliament is dissolved), and because sometimes the Governor General promulgates the Prime Minister's constitutional advice to dissolve parliament after the ministry has explicitly lost the confidence of the Commons. If the Commons withdraws its confidence from the ministry, this does not automatically mean that the Crown also withdraws its confidence from the ministry, which explains why the incumbent Prime Minister can advise - and apart from exceptional circumstances - receive, an early dissolution. If it were true that the Governor General automatically withdraws his confidence from the Prime Minister and revokes his authority to govern as soon as the Commons withdraws its confidence from the ministry, then there would be no such thing as early dissolution, and there would instead only be midparliamentary transitions of power. But the Fixed-Term Parliaments Act, 2011 has thrown all this out of balance. The legislation has replaced the old conventions on confidence matters and with a codified system of continental European-style constructive non-confidence, which has weakened the link between taxation, expenditure, and representation because the Commons can no longer automatically withdraw its confidence from the Ministry by voting against money bills.

\section{$\underline{\text { Achieving Harmony and Securing Liberty }}$}

Incidentally, Responsible Government does not "fuse" the legislature and executive, as many political scientists from the mid- $20^{\text {th }}$ century onward have asserted. ${ }^{188}$ Fusion refers to 
combining two or more distinct things into one new whole and thus entails an outright and often irreversible transformation from one thing into a different thing. But this is clearly not what parliamentary government does - and nothing better demonstrates this fact than the writ, when parliament is dissolved but the executive remains in place. Cabinet ministers lose their status as MPs during the writ but retain their status as Privy Councillors within the governing Ministry. If the legislature and executive were truly "fused," then this state of affairs could not happen because it would be a logical impossibility. Questions of confidence also reveal the separation between the political executive and elected assembly. In modern parlance, confidence votes give the assembly the opportunity to consciously uncouple itself from the government of the day. Instead, Responsible Government maintains a narrow separation of powers, in contrast to the broad separation of powers under a presidential system, and brings the executive and legislature into balance and "harmony," Canadian constitutional historian Alpheus Todd argued in the $19^{\text {th }}$ century, and makes them act on the same wavelength or in concert. ${ }^{189}$ As British political scientists Rod Hague and Martin Harrop (amongst our living contemporaries) say, "the executive in parliamentary government is organically linked to the legislature" given that "the government emerges from parliament." 190

Responsible Government almost promotes political liberty. The Prime Minister and Cabinet represent Canada as a State and as an international legal person (as in le pays), and they govern in a way that should promote Canada's national interest; however, the Prime Minister and Cabinet most certainly cannot "represent all Canadians" in the sense of "reflecting their values in government." The Sovereign and Governor General represent Canada in the sense of la patrie, in something like a "head of the nation" role. But only the House of Commons as a whole "represents all Canadians" - the constituent authority of the body politic of the realm - because we elect Members of Parliament. Within the House of Commons, the loyal opposition represents "the political minority" and makes the representation of political dissent integral to Westminster parliamentarism, ${ }^{191}$ and the government's legitimacy depends on commanding the confidence of a majority of MPs within the chamber. Therefore, no Prime Minister could ever claim to "represent all Canadians" unless his party won all 338 seats in the House of Commons and Canada became a one-party State. As Canadian political scientist Janet Ajzenstat states, "the supreme benefit of parliamentary government is that it protects political opposition, the right to dissent."

\section{V: Dissolution: What It Means and How It Works}

\section{Dissolution of Parliament in General}

In his classic treatise Commentaries on The Laws of England of 1753, Sir William Blackstone described dissolution as "the civil death of a parliament" and explained that it can occur in one of three ways:

1. By the king's will [...];

2. By a demise of the crown $[\ldots]$;

3. By length of time. ${ }^{193}$

First, dissolution "by the king's will” remains the primary method of dissolving parliament in Canada and remained so in the United Kingdom up until the general election of 
2010. Responsible Government, in which "Ministers of the Crown take responsibility for all acts of the Crown, ${ }^{, 194}$ has preserved dissolution by the Crown's will because the Queen or Governor, as the case may be, acts on and in accordance with ministerial advice, save for exceptional circumstances. ${ }^{195}$ Second, dissolution "by a demise of the Crown" no longer exists in either British or Canadian law. This extinct method stems from the nature of the medieval English State; however, it had grown increasingly impractical in the Modern Era after the Glorious Revolution, and legislatures across the British Empire abolished it in the $19^{\text {th }}$ century. Third, dissolution "by length of time", also known as "efflux of time," means that parliament dissolves automatically when it has reached its maximum lifespan, as defined by law, without any intervention on the part of the Crown. In Canada at the federal level and in all the provinces, dissolution by efflux of time remains a theoretical possibility. In practice, however, the Parliament of Canada has never been dissolved by efflux of time, though it was almost allowed to do so in 1896, amidst considerable controversy. In contrast, the Fixed-Term Parliaments Act has made dissolution by efflux of time the new norm or default method in the United Kingdom.

\section{Dissolution of Parliament in Canada}

In Canada, section 50 of the Constitution Act, 1867 stipulates that "every House of Commons shall continue for Five Years from the Return of the Writs for choosing the House (subject to be sooner dissolved by the Governor General) and no longer." Section 4(1) of the Constitution Act, 1982 reaffirms this principle at the federal level and applies it to all the provinces as well. ${ }^{196} \mathrm{Few}$ parliaments and legislatures have approached the maximum five years; instead, Canadian political customs have developed on the presumption that most majority parliaments would live for four years and thus that the electorate vote in elections every four years.

The Constitutional Act, 1791 and the Act of Union, 1841 had previously set the maximum life of a parliament at four years. ${ }^{197}$ In the British House of Commons, Charles Fox and Edmund Burke famously disagreed over the Constitutional Bill, 1791. Fox, the radical Whig, favoured a triennial parliament, as the Westminster Parliament was from 1694 to 1714; in contrast, Burke, the conservative Whig, advocated for a septennial parliament like that of the United Kingdom from 1714 to $1911 .{ }^{198}$ The British Parliament ultimately split the difference in favour of Fox and settled on providing the Canadian legislature with a four-year term. Both of these statutes also codified the requirement that the Assembly must sit at least once per year, thus limiting the maximum duration of a prorogation. The Constitutional Act, 1791 stipulates that Parliament "be called together once at the least in every twelve Calendar Months." ${ }^{199}$ The Act of Union, 1841 states:

31. There shall be a Session of the Legislative Council and Assembly of the Province of Canada once at least in every Year, so that a Period of Twelve Calendar Months shall not intervene between the last sitting of the Legislative Council and Assembly in One Session and the First Sitting of the Legislative Council and Assembly in the next Session; and that every Legislative Assembly of the said Province hereafter to be summoned and chosen shall continue for four years from the day of the return of the writs for choosing the same, and no longer, subject nevertheless to be sooner prorogued or dissolved by the Governor of the said Province. ${ }^{200}$ 
Today, the authority to summon, prorogue, dissolve parliament rests with the Crown of Canada by virtue of sections 9, 38, and 50 of the Constitution Act, 1867 and sections 4(1) and 20 of the Constitution Act, 1982. They say:

9. The Executive Government and Authority of and over Canada is hereby declared to continue and be vested in the Queen.

38. The Governor General shall from Time to Time, in the Queen's Name, by Instrument under the Great Seal of Canada, summon and call together the House of Commons.

50. Every House of Commons shall continue for Five Years from the Day of the Return of the Writs for choosing the House (subject to be sooner dissolved by the Governor General), and no longer.

4. (1) No House of Commons and no legislative assembly shall continue for longer than five years from the date fixed for the return of the writs at a general election of its members.

20. There shall be a Session of the Parliament of Canada once at least in every Year, so that Twelve Months shall not intervene between the last Sitting of the Parliament in one Session and its first sitting in the next Session.

Dissolving parliament, issuing the writs of election, and summoning the next parliament are promulgated through three separate proclamations. ${ }^{201}$ First, the Governor dissolves the legislature on and, apart from exceptional circumstances, in accordance with, the advice of the First Minister. Second, the Governor issues the writs of election on the advice of Cabinet and in accordance with section 57(1) of the Canada Elections Act. Third, the Governor summons the first session of the next parliament pro forma on the advice of the First Minister. Critics of the established constitutional position argue that the First Minister possesses too much power because he could call a "snap election" to the advantage of his own governing party and to the detriment of the opposition.

The documents in the Canada Gazette show that the Government of Canada still follows essentially the same procedure that the Manual of Official Procedure of the Government of Canada described in 1968 by issuing three separate proclamations:

1. the dissolution of the old parliament,

2. the issuing of writs of election,

3 . and the pro forma summoning of a new parliament. ${ }^{202}$

For example, in 2011, the Governor General issued the Proclamation Dissolving Parliament "by and with the advice of Our Prime Minister of Canada", based on the Prime Minister's Instrument of Advice, an executive instrument which he provides the Governor General individually without reference to Cabinet. ${ }^{203}$ The Governor-in-Council then issued the Proclamation Issuing Writs of Election "by and with the advice of Our Privy Council for Canada," which means that Cabinet (with a minimum quorum of four) advised the Governor General through an Order-in-Council. ${ }^{204}$ Finally, the Governor General issued the Proclamation Summoning Parliament to Meet on 30 May 2011 "by and with the advice of Our Prime Minister of Canada", again through a unilateral Prime Ministerial Instrument of Advice. ${ }^{205}$ While the provinces might not use the same set of three separate executive instruments, they still take the same three steps. For instance, in most provinces, the Premier still advises the Lieutenant 
Governor to dissolve the legislature through an Order-in-Council, which means that he must still involve Cabinet in the decision, because the quorum for Cabinet as a committee of the Executive Council is four.

\section{Dissolution of Parliament in the United Kingdom}

Until the Tudor period, English parliaments typically lasted, at most, one year, and "parliament" did not sit permanently and regularly as it does today. Instead, the Sovereign summoned "a parliament" only when necessary. Historians also often refer to the Tudor and Stuart Parliaments by specific names like Henry VIII's "Reformation Parliament" (1529-1536), James I's "Blessed Parliament" (1604-1611), or Charles I's "Useless Parliament" of 1625. Not until Thomas Cromwell and the Henrician Reformation of the 1530s did the civil service emerge as a separate entity from the king's household and parliament emerge as a policy-making body beyond obtaining supplies. $^{206}$ Henceforth, parliament would play a regular, ongoing, and active role in the modern State as opposed to its sporadic and ad hoc function in the medieval State. In the Middle Ages, a parliament could dissolve automatically upon the demise of the Crown without causing disruption to the Realm. If anything, this principle gave the new Sovereign more room to manoeuvre and pursue his own aims.

Parliament's transition from count noun to mass noun after the Glorious Revolution and the passage of the Triennial Act of 1694 reflected its growing importance, and individual parliaments thereafter took on perfunctory names like "The $3{ }^{\text {rd }}$ Parliament of King William III." Blackstone's second method comes into play at this stage. Parliament modified the medieval, common-law custom of automatic dissolution "by a demise of the Crown" through the Succession to the Crown Act, 1707, which instead allowed the parliament to continue for up to six months after a demise of the Crown. Finally, the Westminster Parliament abolished this principle altogether through the Representation of the People Act, 1867 so that a parliament would continue irrespective of a demise of the Crown. Similarly, the United Province of Canada abolished the principle of automatic dissolution upon the demise of the Crown in 1843, and the Dominion of Canada re-affirmed its abolition in new legislation in $1867 .^{207}$

The statutory elimination of what Blackstone lists as the second method of dissolution fits a general legislative pattern over the $17^{\text {th }}, 18^{\text {th }}$ and $19^{\text {th }}$ centuries whereby the Westminster Parliament has passed statutes which modify common law principles so that overall English and British law reconciles with the fact that the Crown is a corporation sole, which Blackstone also pointed out in this treatise. ${ }^{208}$ Laws like the Succession to the Crown Act, 1707 and the various Crown Estates Acts therefore replaced the Sovereign's personal capacity with the Sovereign's legal capacity as the default authority of State functions. In other words, the Sovereign now summons parliaments in his or her perpetual legal capacity, which transfers intact to his or her successor upon a demise of the Crown, and no longer in his or her mortal personal capacity. ${ }^{209}$

In England and the United Kingdom, the legal status of dissolution by the sovereign's will has fluctuated multiple times since 1641 , with statutes variously putting that prerogative authority into abeyance, fully restoring it, regulating it, and finally, putting it into abeyance once again in 2011. The Fixed-Term Parliaments Act, 2011 - a piece of legislation whose radicalism is frequently under-estimated - has put Blackstone's first method of dissolution, that by the 
sovereign's will, into abeyance again, such that the British Crown no longer plays any role whatsoever in dissolving parliament.

The general election of 2010 occurred under the old procedure, which relied on three steps set out in one proclamation. The Queen issued this proclamation "by and with our advice of the Privy Council," to dissolve one parliament on 12 April 2010, instruct the Lord Chancellor to issue the writs of election, and summon the next parliament on 18 May 2010. ${ }^{210}$ The new British procedure under the Fixed-Term Parliaments Act, 2011 first played out for the general election of 2015. It includes three steps for dissolving the parliament, issuing the writs of election, and summoning the next parliament, but the first now flows from the authority of The Fixed-Term Parliaments Act itself and therefore no longer stem from the executive authority of the British Crown.

First, Parliament dissolves by efflux of time in accordance with section 3(1) of the act.

The Parliament then in existence dissolves at the beginning of the 17th working day before the polling day for the next parliamentary general election as determined under section 1 or appointed under section 2(7).

Second, pursuant to section 3(3), the Lord Chancellor and the Secretary of State issue the writs of election for the United Kingdom of Great Britain and Northern Ireland's 650 constituencies.

Once Parliament dissolves, the Lord Chancellor and, in relation to Northern Ireland, the Secretary of State have the authority to have the writs for the election sealed and issued (see rule 3 in Schedule 1 to the Representation of the People Act 1983).

Third and finally, the Prime Minister advises the Queen to issue a proclamation summoning the next parliament on a certain date, now in accordance with section 3(4)(a).

Once Parliament dissolves, Her Majesty may issue the proclamation summoning the new

Parliament which may- (a) appoint the day for the first meeting of the new Parliament.

As the Cameron-Clegg government stated in this press release in 2015, "Parliament has been prorogued and will automatically dissolve on 30 March under the Fixed-term Parliaments Act." ${ }^{111}$ It adds, "The Prime Minister will ask Her Majesty to summon the new Parliament to meet on Monday 18 May," which means that the Queen still summons the new parliament on the Prime Minister's advice - but this authority now flows from section 3(4)(a) of the Act and no longer purely from the prerogative. The London Gazette records the proclamation summoning the next parliament for 18 May 2015. ${ }^{212}$ The proclamation also reiterates that the Lord Chancellor shall issue the writs of election.

This chart illustrates the comparison of the two methods of dissolution in the United Kingdom which have pertained in recent years. 
Figure 2: How Parliaments Are Dissolved and Elections Held in the United Kingdom

\begin{tabular}{|l|l|}
\hline \multicolumn{1}{|c|}{ Dissolution Pre-Fixed Term Parliaments Act } \\
$\begin{array}{l}\text { Three executive actions in one proclamation issued by } \\
\text { the Queen on ministerial advice on 12 April 2010: }\end{array}$ & \multicolumn{1}{c|}{$\begin{array}{c}\text { Dissolution Post-Fixed Term Parliaments Act } \\
\text { These same three actions now flow from the authority of } \\
\text { the } \text { Act itself. }\end{array}$} \\
\hline 1. Queen dissolves parliament & 1. Parliament dissolves by efflux of time \\
\hline 2. $\quad$ Lord Chancellor issues writs of election & 2. Lord Chancellor issues writs of election \\
\hline 3. $\quad \begin{array}{l}\text { Lord Chancellor summons the next parliament for } \\
\text { 18 May 2010. }\end{array}$ & $\begin{array}{l}\text { 3. The Queen summons the next Parliament on the PM's } \\
\text { advice as stated in the } \text { Act. }\end{array}$ \\
\hline
\end{tabular}

The Fixed-Term Parliaments Act, 2011 put the executive authority over dissolution into abeyance; the Westminster Parliament can now ordinarily be dissolved only by efflux of time, or in two extraordinary circumstances set out in section 2 of the statute, by the will of the House of Commons itself. In one case, parliament may be dissolved early if two-thirds of MPs pass a motion "That there shall be an early parliamentary general election." In the other case, if the Commons votes non-confidence in Her Majesty's Government by simple majority ("That this House has no confidence in Her Majesty's Government") but subsequently fails to pass a confirmation vote for a new government ("That this House has confidence in Her Majesty's Government") within 14 days, then Parliament shall automatically dissolve in order to break the deadlock. The defeated government would remain in a caretaker capacity during the ensuing election and until the new Parliament meets and passes a confirmation vote in favour of a new government. But the Queen no longer dissolves parliament on the advice of the Prime Minister or under any circumstances whatever. The early general election of 2017 resulted from the first invocation of one of the two procedures for early dissolution.

\section{VI: Historical Antecedents of Fixed-Date Elections in Canada, 1972-2008}

\section{The New Democratic Party, 1972-1974}

Three New Democratic MPs tabled four private members' bills on fixed-date elections in the $28^{\text {th }}$ and $29^{\text {th }}$ Parliaments between 1972 and 1974 , though none received any parliamentary debate or scrutiny because they all died on the Order Paper at First Reading. Three of the four bills are identical. However, these MPs did explain the rationale for their bills in the "explanatory notes" section that accompanied them at First Reading. Between 1962 and 1972, Canadians elected five parliaments, four of which were minority parliaments. These New Democratic MPs sought to stabilize this succession of minority parliaments into a four-year cycle by limiting the Crown's authority over dissolution. Prior to the enactment of the Constitution Act, 1982, the Parliament of Canada could have placed significant restrictions on, or even abolished altogether, the Crown's authority over dissolution under s.91(1) of the British North America Act, 1867, just as the Westminster Parliament did through the Fixed-Term Parliaments Act, 2011. This former provision (repealed in 1982 but now incorporated in principle into the Section 44 Amending Formula) entered into force in 1949 and granted the Parliament of Canada the head of legislative power over "the amendment from time to time of the Constitution of Canada" in matters of federal jurisdiction. 
William Peters, the New Democratic MP for the riding of Timiskaming in Ontario introduced Bill C-112, An Act to amend the British North America Acts, 1867 to 1965, (duration of the House of Commons), in the $4^{\text {th }}$ session of the $28^{\text {th }}$ Parliament. This bill would have provided both a range of the maximum life of the parliament of four to five years, as well as a procedure by which two-thirds of MPs could vote in favour of an early dissolution prior to the four-year mark. It would have replaced section 50 of the Constitution Act, 1867 with the following:

50(1) Every House of Commons shall continue for four years from the day of the return of the writes for choosing the House (subject to be sooner dissolved by the Governor General by only upon a resolution therefore of the House decided by not less than two-thirds of the voices other than that of the Speaker), and no longer than five years.

(2) A request by a member for leave to move for dissolution shall be deemed by Mr. Speaker to be in order and a definite matter of urgent public importance if the request is supported by at least one hundred voices. ${ }^{213}$

However, the explanatory notes suggest that Peters intended that the bill would limit the life of the parliament to an absolute maximum of four years; the proposed section $50(1)$ therefore should not have contained the clause "and no longer than five years":

\begin{abstract}
The principle of this Bill is that a House of Commons, when elected, should devote itself to the nation's business without fear of electoral interruption - save in a public emergency - for a minimal period of four years [...]. The proposed amendment contains provisions for dissolution of Parliament within the four-year period when two-thirds of the House believe that a dissolution is a public necessity. ${ }^{214}$
\end{abstract}

The Governor General dissolved the $28^{\text {th }}$ Parliament on Prime Minister Trudeau's advice on 1 September 1972; the Parliament had first convened on 12 September 1968, so it lasted almost precisely four years under the Crown's traditional authority over dissolution. Peters presented the procedure where two-thirds of MPs can vote for an early dissolution as a guarantee that early elections would only occur based on "public necessity" and not merely for the partisan gain of the governing party. The Fixed-Term Parliaments Act, 2011 of the United Kingdom prescribes a similar procedure where two-thirds of MPs can force an early dissolution.

Peters concluded with the political Romantic's ideal of how Westminster parliamentarism should operate, as if elected Members of Parliament, who ran as candidates for various political parties, could or should somehow elevate themselves above partisan politics:

The bill seeks to curb the infiltration of party "campaign" extremism into the House of Commons and to help provide for a working House where none are for the Party and all are for the State.

He also included a long excerpt of President George Washington's Farewell Address and his famous warning on "the dangers of parties in the state," an idea also steeped in civic republicanism and political Romanticism.

Douglas Rowland, New Democratic MP for Selkirk, Manitoba, also tabled his Bill C-123 in the $4^{\text {th }}$ session of the $28^{\text {th }}$ Parliament but offered a different formula for fixed-date elections. Bill C-123 would have reduced, unambiguously, the maximum life of the parliament from five years to four years and would have permitted early dissolution only if the Commons had 
defeated the Government on an explicit vote of non-confidence or on a bill that the Government had deemed a matter of confidence, or if the House of Commons adopted a motion by a simple majority that the parliament be dissolved early. Rowland and his New Democratic colleague Winona MacInnis introduced identical bills in the $29^{\text {th }}$ Parliament.

50. Every House of Commons shall continue for four years from the day of the return of writs for choosing the House and no longer: provided that, and notwithstanding any Royal Prerogative, the Governor General may dissolve Parliament during that period of four years

a) where the government is defeated

i) on a motion expressing no confidence in the government; or

ii) on a vote on a specific Bill or portion of a Bill which the Government considers, and has previously declared should be construed as a motion of want of confidence, or

b) following the adoption of an affirmative resolution of the House of Commons that Parliament be dissolved. $^{215}$

Overall, Rowland's and MacInnis's bills would have become futile laws in both a majority parliament and in a minority parliament. Unlike the Fixed-Term Parliaments Act, 2011, which mandates that a super-majority of two-thirds of MPs can bring about an early dissolution, Rowland's bill would have allowed a simple majority of MPs to precipitate an early election. In a majority parliament, any government could under that rule easily orchestrate its own defeat by asking a backbencher to table a motion for early dissolution and instructing the parliamentary party on the Government side of the Commons to support it. In a minority parliament, a government could also orchestrate its defeat by tabling a money bill or deeming a government bill a matter of confidence and provoking the opposition to vote against it. The bills also seem to presume that a government defeat in a minority parliament necessarily requires an early election because they do not contain provisions on constructive non-confidence or confirmation voting or any other procedure outlining an intra-parliamentary change of government. A government defeated under these provisions could still choose to resign and make way for the opposition, but nothing in the bill would require the Prime Minister to do so. The bill would therefore not have stabilized the lifecycle of minority parliaments because the Crown's authority over dissolution would have remained strong under its terms.

These three bills tabled by Rowland and MacInnis contained another flaw. Rowland stated that his bill would "abolish the Royal Power of Dissolution with a view to reducing the arbitrary power of the Prime Minister and enhancing the independence of the private Member of Parliament." ${ }^{216}$ (Peters and MacInnis did not make this claim). In fact, none of the four bills would have abolished the Crown's authority over dissolution but merely have limited it. Rowland's and MacInnis's bills recognize that the "Governor General may dissolve parliament during that period of four years." Peters's bill C-112 recognizes that the House of Commons would last four years but "subject to be sooner dissolved by the Governor General but only upon a resolution therefor of the House decided by not less than two-thirds of the voices other than that of the Speaker." Prior to 1982, the Parliament of Canada or a provincial legislature could have abolished the Crown's authority over dissolution. But the Parliament of Canada could not have abolished that authority through this wording because the constitutional convention inherent to Responsible Government is that the Governor General acts on the advice of the Prime Minister and that the Governor-in-Council acts on the advice of Cabinet. Dissolution is also an executive power. The Prime Minister would therefore have had to advise the Governor General to dissolve Parliament "where the government is defeated" or "following the adoption of an 
affirmative resolution of the House of Commons that Parliament be dissolved" or "upon a resolution therefor of the House."

The New Democratic Party's efforts to reform dissolution had become little more than a faded memory by the late 1980s. While there is no evidence that they influenced the later Canadian Alliance and Conservative Party initiatives, they show that constitutional reform of the Crown's authority over dissolution could have taken a variety of forms and would have been easier to achieve if the Trudeau government had supported them prior to 1982.

\section{The Reform Party, the Canadian Alliance, and the Conservative Party, 1988-2007}

The Canadian model of fixed-date election laws emerged after and because of Prime Minister Chretien's two early dissolutions of two majority parliaments in 1997 and 2000. In response to such criticism over the "undemocratic" power of dissolution, the Parliament of Canada and nine provincial legislatures as of July 2018 have adopted the Canadian model of the fixed-date elections law. The "Canadian model" of fixed-date elections refers to a statute law that effectively reduces the maximum life of the parliament from five years to somewhere between four and five years (yet purports to fix the date of the election every four years), but which in fact preserves the established constitutional positions of the Governor and First Minister through a non-derogation clause in order to avoid an amendment under section 41(a) of the Constitution Act, 1982. ${ }^{217}$ The maximum life of a parliament is prescribed by section 50 of the Constitution Act, 1867 and section 4.1 of the Constitution Act, 1982 and is subject to either the Section 44 Amending Formula, where the Parliament of Canada alone can amend the Constitution "in relation to the executive government of Canada or the Senate and House of Commons," or under the Section 45 Amending Formula, where a provincial legislature alone can amend the province's constitution under either section 45 (the provincial legislature acting alone) or section 44 of the Constitution Act, 1982 (the Parliament of Canada acting alone); in contrast, the Crown's authority itself over dissolution, as exercised by the governor on the advice of the First Minister, is constitutionally entrenched by section 41(a) of the Constitution Act, 1982. ${ }^{218}$ The two are separate constitutional questions and in turn pertain to two different amending formulas. $^{219}$

In this respect, the Canadian fixed-date election laws are equivalent to the Triennial Act, 1664, the Triennial Act, 1694, the Septennial Act, 1716, and the Parliament Act, 1911, through which the Westminster Parliament variously shortened and lengthened the maximum duration of an individual parliament through statute law. ${ }^{220}$ British Columbia pioneered this Canadian model and passed its fixed-date elections law in 2001. Newfoundland and Labrador passed a similar law in 2004 - though this law contains a unique, and probably unconstitutional, variation pertaining to mid-parliamentary changes of government. Ontario passed its equivalent law in 2005, followed by New Brunswick in 2007, Saskatchewan, Prince Edward Island, and Manitoba in 2008, Alberta in 2011, and Quebec in 2013. Nova Scotia now stands as the lone resolute redoubt of the old Canadian custom.

Most Canadian Ministers of the Crown, at least in their respective Second Reading debates, presented their government bills for fixed-date elections as a means of preventing a First Minister who leads a majority government from calling a "snap election." They argued that the 
non-derogation clause merely ensures that in a minority parliament, the First Minister could still secure the early dissolution of a minority parliament if the assembly had withdrawn its confidence from the government beforehand. Various governments and assemblies across Canada accepted this arrangement, which reflects a preference for early dissolution over midparliamentary changes of government. In reality, the Canadian model of fixed-date elections merely sought to remove the initiative - and not the authority - of dissolution from the First Minister. The First Minister would theoretically only advise dissolution after his government had lost the confidence of the Assembly, or in order to ensure that election day occurs on the date that the statute prescribes. The laws have, however, failed to achieve even this modest goal. While the Canadian fixed-date election laws have effectively shortened the maximum life of a parliament by exceeding the baseline standard in the Constitution Acts, they do not ensure that the parliament must last a minimum of four years. ${ }^{221}$ Parliament can still be dissolved sooner because the non-derogation clauses were designed specifically to avoid a constitutional amendment; they thus preserve the established constitutional positions of the First Minister and Governor. Only a constitutional amendment that abolishes the Crown's authority over dissolution itself could eliminate "snap elections." In reality, the non-derogation clauses render these laws exercises of pure political cynicism - where the politician denounces cynicism while himself adopting a cynical tactic - because this mechanism preserves the status quo in law and in convention: the Governor still exercises dissolution on and, save for exceptional circumstances, in accordance with, the advice of the First Minister.

At the federal level, the Reform Party championed both fixed-date elections and a form of constructive non-confidence in the late 1980s and throughout the 1990s, though it did not cite a specific snap election as a grievance. In a pamphlet from 1992, the Reform Party pledged to "support the holding of elections every four years at a predetermined date."222 In 1988, the Reform Party favoured constructive non-confidence and treated the possibility of midparliamentary changes of government, rather than early dissolution, as the preferred option:

The defeat of a government measure in the House of Commons should not automatically mean the defeat of the government. Defeat of the government motion should be followed by a formal motion of non-confidence, the passage of which would require either the resignation of the government or dissolution of the House for a general election. ${ }^{223}$

In its 2000 platform, the Canadian Alliance stated the principle of fixed-date elections more forcefully but abandoned the Reform Party's proposal on constructive non-confidence.

A Canadian Alliance government will set fixed election dates every four years, to remove from the Prime Minister the discretionary power to call an early snap election or hold onto office late. ${ }^{224}$

The Canadian Alliance sought to eliminate the Prime Minister's discretion on dissolution in order to preclude both early elections and "late" elections that break the quadrennial custom. By this logic, the election of 1993 would fall under the latter, and the election of 1997 would fall under the former. The Alliance was therefore expressing consternation toward both the Mulroney and Campbell governments on the one hand because of the "late" election of 1993 that allowed the former Progressive Conservative Party to cling to power for five years, and the Chretien government on the other, because the early dissolutions of 1997 and 2000 allowed the Liberals to sustain themselves against a weak and divided opposition. However, the Canadian Alliance conflated the term of the Prime Minister - which begins when the Governor General 
commissions him and ends only upon his resignation, dismissal, or death -with the life of a parliament, which at that time could last for a maximum of five years. ${ }^{225}$ A Prime Minister's term can therefore span the life of two or more parliaments, and an election could only be characterized as "late" if a Prime Minister attempted to usurp section 50 of the Constitution Act, 1867. Even then, such a usurpation would be unsuccessful because section 50 means that Parliament would dissolve automatically by efflux of time after five years, pursuant to this provision itself, and not pursuant to the Governor General's proclamation of dissolution. ${ }^{226}$

The Conservative Party of Canada also originally sought to eliminate the Prime Minister's discretion on dissolution. Its 2004 platform pledged to implement a law:

requiring fixed election dates every four years, except when a government loses the confidence of the House (in which case an election would be held immediately, and the subsequent election would be four years later on the date established in the legislation).

As part of this "Demand Better" platform, the Conservatives deemed the fixed-date election law necessary because "Canadians are appalled that we are subject to mid-term elections, called simply for the personal and partisan benefit of the Prime Minister."227 The Conservative Party inherited the Canadian Alliance's penchant of misinterpreting key aspects of Westminster parliamentarism: there is simply no such thing, in the Canadian system, as a "midterm election," which is an American phrase referring to congressional elections that occur at the half-way point of the president's four-year term. Presumably, this phrase refers to an early election that cuts short the life of a parliament, because the Ministry's term in office ends only upon the resignation, dismissal, or death of the Prime Minister and is therefore not fixed or inexplicably tied to the life of any one parliament.

The Conservative Party's platform in 2004 (and in 2006) also conflates several issues and suggests, incorrectly, that a mid-parliamentary change of government cannot occur. If the government loses the confidence of the Commons, the Prime Minister could either resign so that the Governor General can appoint an alternative government, or he can advise the Governor General to dissolve the assembly early and draw up the writ for fresh elections. But if the Commons could support an alternative government - as some minority parliaments could - the Governor General could reject the Prime Minister's advice to dissolve Parliament, and thereby dismiss him and appoint a new Prime Minister, who would in turn take responsibility for his predecessor's dismissal and command the confidence of the Commons. ${ }^{228}$ Dissolution need not occur "immediately" after the Government loses the confidence of the Commons, which the Reform Party well understood in 1988.

The Conservatives formed the official opposition in that $38^{\text {th }}$ Parliament (2004-2005), and Opposition Leader Stephen Harper introduced a private member's bill on fixed-date elections in an attempt to fulfill the campaign promise. While Bill C-512 did not go beyond First Reading in the House of Commons, it reveals a distinct evolution in the Conservative Party's strategy. Harper presented this ill-fated Dissolution of Parliament Act as a constitutional amendment bill because it would have repealed section 50 of the Constitution Act, 1867 and replaced the quintennial fixed-term parliament with a quadrennial fixed-term parliament. Harper's bill from 2004 would have been constitutional and because it did not derogate from the executive authority over dissolution and thus did not pertain to section 41(a) of the Constitution 
Act, 1982 and "the office of the Governor General"; instead, it would only have shortened the maximum life of a parliament and therefore relied on the amending formula under section 44 of the Constitution Act, 1982. The bill contained a non-derogation clause, "Nothing in this Act affects the power of the Governor General to dissolve the Parliament whenever the Governor General sees fit." ${ }^{229}$ It would not have prevented early dissolution, but by amending the Constitution Act, 1867 itself to shorten the maximum life of a parliament to four years, it would have codified the quadrennial custom and made "late elections" impossible. It would have set fixed-date elections to a very American schedule of every third Monday in November, beginning in 2004. However, this bill did not take into account section 4 of the Constitution Act, 1982, which reaffirms the quintennial maximum for a federal parliament and establishes the quintennial maximum for the provincial legislatures. The new section 50 of the Constitution Act, 1867 would then have contradicted section 4 of the Constitution Act, 1982, which would presumably also have to be amended in line with its sister provision.

During the general federal election of 2005-2006, the Conservatives reiterated their pledge from 2004. They would:

introduce legislation modelled on the $\mathrm{BC}$ and Ontario laws requiring fixed election dates every four years, except when a government loses the confidence of the House (in which case an election would be held immediately, and the subsequent election would follow four years later) ${ }^{230}$

The Harper Government introduced Bill C-16, which amended the Canada Elections Act instead of the Constitution Act, 1867. It added the non-derogation clause as section 56(1) of the Canada Elections Act and prescribes in section 56(2) that the fixed-date elections occur on the third Monday in October, beginning in 2009. ${ }^{231}$ Since section 56(2) depends upon section 56(1), this amendment preserves the established constitutional positions of the Governor General and Prime Minister. ${ }^{232}$

Date of General Election

Powers of Governor General preserved

56.1 (1) Nothing in this section affects the powers of the Governor General, including the power to dissolve Parliament at the Governor General's discretion.

Election dates

(2) Subject to subsection (1), each general election must be held on the third Monday of October in the fourth calendar year following polling day for the last general election, with the first general election after this section comes into force being held on Monday, October 19, 2009.

Minister of Justice and Attorney General Rob Nicholson appeared before the Standing Committee on Procedure and House Affairs on the fixed-date elections bill in 2006. Nicholson reiterated the standard political line that "the bill does not affect the powers of the Governor General to call an election sooner if a government loses the confidence of the House." ${ }^{, 233}$ But he was less forthright in acknowledging that it also did not affect the power of the Governor General to dissolve parliament on the advice of the Prime Minister if the government has not first lost the confidence of the Commons. Minister Nicholson then rejected the insertion of a clause that would "constrain the Prime Minister's ability to request dissolution of Parliament to certain circumstances." He explained: 
The Governor General's legal power under the Constitution and the exercise of that power on the advice of the Prime Minister are fundamentally and inseparably linked. If one limits the Prime Minister's ability to advise, one risks constraining the Governor General's powers in a way that would be unconstitutional. ${ }^{234}$

In addition, the phrase "unless the government has lost the confidence of the House" (which appeared in the Conservative Party's campaign literature and in the speeches of the Harper Government) does not necessarily mean, "unless the government loses a vote of confidence" because, barring the imposition of constructive non-confidence, the Government retains the discretion to declare whether or when it has lost the confidence of the Commons on some matters. Nicholson then affirmed that eliminating the Crown's power of dissolution would require an amendment under section 41(a) of the Constitution Act, 1982, which is why the bill "does not in any way fetter the discretion or the prerogative of the Governor General.",235

Patrick Monahan appeared before the Senate Committee on Legal and Constitutional Affairs and agreed:

Nothing [in the bill] would legally prevent the Prime Minister, if he claimed that this was a matter of some extraordinary set of circumstances that required an election, from seeking a dissolution by advising the Governor General to dissolve the House, and the Governor would act on the advice of the Prime Minister, in accordance with the principles of Responsible Government. ${ }^{236}$

In reality, the circumstances do not even have to be extraordinary - as the five precedents showed between 2008 and 2015.

\section{VII: The Early Dissolution of 2008: Constitutional Conventions and Critique of Heard, Aucoin et al., and the Conacher Rulings}

\section{Introduction}

In August 2008, Prime Minister Harper described the $39^{\text {th }}$ Parliament as "dysfunctional"; he had judged that his single-party minority government would soon lose control of the legislative agenda and therefore the confidence of the Commons ${ }^{237}$ Harper then met individually with New Democratic leader Jack Layton and Bloc Quebecois leader Gilles Duceppe; Liberal leader Stephane Dion opted not to meet him. Harper cited these meetings as evidence that the $39^{\text {th }}$ Parliament would have become too dysfunctional in its scheduled fall sitting to pass any government bills. Harper determined that his government had, in effect, lost the confidence of the Commons and the ability to control the legislative agenda, or that the three parties in opposition would have tabled a motion of non-confidence. On 7 September 2008, Governor General Michaelle Jean dissolved the $39^{\text {th }}$ Parliament on and in accordance with the advice of Prime Minister Stephen Harper.

The general federal election of October 2008 occurred one year earlier than the Canada Elections Act had originally scheduled it, for 19 October $2009 .{ }^{238}$ In reality, the Conservatives, Liberals, New Democrats, and Bloc Quebecois all wanted an early election, despite some insistence to the contrary. In early August 2008, Liberal leader Stephane Dion started openly musing about voting down the Harper government upon the $39^{\text {th }}$ Parliament's scheduled return on 15 September 2008, and Bob Rae (then Shadow Foreign Minister) made similar 
insinuations. ${ }^{239}$ Since Bob Rae had brought down Joe Clark's single-party minority government in December 1979, that was no idle threat! In August 2008, columnist Chantal Hebert also acknowledged that the Harper government had, in practical terms, lost control of the agenda of the House of Commons at some point in 2007, and therefore lost its confidence, when the Liberals abdicated their duty as Official Opposition to the New Democrats by abstaining on key confidence votes:

\begin{abstract}
It can be argued that the Harper government actually lost the confidence of Parliament some time ago. Since the 2007 budget, no opposition party has been willing to support the bulk of its pivotal legislation. The only reason the government is still in place is an extraordinary Liberal decision to abstain from key votes. But if a Parliament is about more than the government, then the Liberal failure to act as a full-fledged Official Opposition has made the dynamics of this one dysfunctional. ${ }^{240}$
\end{abstract}

This early dissolution provoked a political controversy because it seemed to contradict, and even violate, the Harper government's own fixed-date election law. In 2008, several reporters promoted Duff Conacher's and Errol Mendes's assertion that "Harper broke his own law!" when he obtained an early dissolution ten years ago, ${ }^{241}$ though a few journalists at the time did correctly point out that the fixed-date election law kept the established constitutional positions of the Governor General and Prime Minister intact. ${ }^{242}$

Peter Russell and Andrew Heard have argued that the fixed-date election law created a constitutional convention that the Prime Minister could no longer advise an early dissolution without first having lost the confidence of the Commons, and that therefore Prime Minister Harper acted unconstitutionally in $2008 .^{243}$ This argument pertains to the Constitution of Canada, which consists of the written provisions of the Constitution Acts as well the uncodified principles and conventions of Responsible Government, normally called "constitutional conventions." However, that which they promote as a constitutional convention would in fact threaten the wellestablished conventions of Responsible Government and undermine the constitutional positions of the Governor General and Prime Minister. It is not a convention at all. In fact, Prime Minister Harper acted neither illegally nor unconstitutionally.

Most of those who denounced Harper in 2008 declined to extent the same criticism to the early dissolutions of Premier Marois and Premier Wynne of 2014, which at least happened in minority parliaments, as well as on the theoretically more egregious and brazen early dissolutions of majority parliaments that Premier Prentice and Premier MacLauchlan undertook in 2015. No ink has been spilt on these "breaches of convention." In fact, in the summer of 2018, several columnists encouraged Prime Minister J. Trudeau to advise an early dissolution for the fall of 2018, one year early, irrespective of the fixed-date election law. ${ }^{244}$

\title{
The Nature of Constitutional Conventions
}

Constitutional conventions are unwritten, politically enforceable norms that exist in order to complement, contextualize, or regulate the exercise of constitutional principles, statute laws, and the codified elements of the Constitution of Canada. ${ }^{245}$ Norms imply exemptions and allow for exceptions - particularly in situations without precedent - and conventions help political actors determine how they ought to act in a given situation. ${ }^{246}$ More fundamentally, 
constitutional conventions are the manifestations of constitutional principles, which underpin conventions and provide their normative justification. ${ }^{247}$ Since constitutional conventions are derived from constitutional principles, a convention may be called into question and need to be re-evaluated or altered when its standard application would no longer conform to its underlying principle and would detract from its normative justification. ${ }^{248}$ In contrast, a custom refers to what Heard calls somewhat dismissively "symbolic traditions or pleasing rituals whose observance or absence has no substantial impact on the operation of constitutional rules and principles." 249 These customs not strictly speaking necessary to the conduct or operation of Responsible Government include the tradition whereby the Sovereign or Governor General reads the Speech from the Throne from the Senate - which, of course, does not exist in the provinces, half of which were always unicameral and half of which had abolished their Legislative Councils by the mid- $20^{\text {th }}$ century.

An advocacy group called Democracy Watch, then run by Duff Conacher, challenged the early dissolution of the $39^{\text {th }}$ Parliament before the Federal Court, which denied the application. ${ }^{250}$ The Federal Court of Appeal then dismissed Democracy Watch's appeal. ${ }^{251}$ However, the Federal Court did respond to the arguments of the applicants and the respondents, providing some valuable insights into the established constitutional positions of the Governor General and Prime Minister. In their submission to the Federal Court, Conacher and Democracy Watch argued that Parliament intended that the federal fixed-date elections law would "stabilize" the lifecycle of minority parliaments. ${ }^{252}$ But the Canadian model of fixed-date election law neither stabilizes, nor intends to stabilize, minority parliaments so that they live for four years. ${ }^{253} \mathrm{~A}$ law designed to stabilize minority parliaments would, logically, prescribe a mid-parliamentary change of government as the preferred option and only allow an early dissolution as a last resort. Such a system would therefore also require constructive non-confidence, which the Fixed-Term Parliaments Act, 2011 of the United Kingdom has imposed. The British system and various parliamentary systems in continental Europe show that statutory fixed-date elections go hand in hand with constructive non-confidence - and that this tandem fundamentally alters the balance of Responsible Government.

Conacher argued that Prime Minister Harper had created a constitutional convention that dissolution without a loss of confidence could no longer be advised: "conventions that have been incorporated into legislation are enforceable by the courts as ordinary statutes [...]. ${ }^{, 254}$ In his submission to the Federal Court, Conacher relied mainly upon the scholarship of Andrew Heard. But this argument contains numerous flaws and fundamentally misinterprets the nature of constitutional conventions.

In reality, statute laws do not create new constitutional conventions, particularly not ones that would contradict constitutional principles and the Constitution Acts. And any convention codified in statute ceases to be a convention, which must, by definition, by uncodified. As the Government remarked in its memorandum, "it is unclear how the enactment of a statute can produce a new constitutional convention." 255 A statute law on fixed-date elections that deliberately preserves the power of the Crown to dissolve the legislature by extension necessarily preserves the constitutional relationship between the Governor and First Minister; it does not create a new constitutional convention by implication. Statutes can be drafted to take into account pre-existing and well-established constitutional conventions, but Parliament cannot 
simply conjure up a new constitutional convention and incorporate it by implication into statute law for at least two reasons: first, because constitutional conventions emerge and cannot be designed or imposed; second, because codifying a pre-existing constitutional convention in statute moves the former constitutional convention from the realm of political enforceability to the purview of the courts and legal enforceability - two different, and mutually exclusive, concepts. In short, what Conacher suggests is a constitutional paradox: codifying constitutional conventions in statute or the Constitution of Canada would mean that they cease to be conventions.

The Canadian fixed-date election laws neither codify nor incorporate nor imply any such convention. The law could only codify a convention outright by including a statutory provision to the effect that the Prime Minister shall not advise early dissolution unless his government has first lost the confidence of the Commons. ${ }^{256}$ Even if the law did so, the "convention" would cease to be a politically enforceable convention altogether and would instead become a legally enforceable statutory provision. While constitutional conventions can clarify how the executive exercises a statutory or constitutional authority, constitutional conventions are not justiciable and do not become justiciable merely because a statute law might imply or recognize their existence. Heard correctly points out that statute laws can, upon the moment of their enactment, acknowledge the existence of constitutional conventions that would affect their interpretation. For instance, the written provisions in sections 9 to 15 of the Constitution Act, 1867, which pertain to executive authority in and over Canada, mention only the Queen, Governor, and Governor-in-Council yet also imply the core constitutional conventions of Responsible Government: that Ministers of the Crown take responsibility for all acts of the Crown, such that the Queen and Governor General act upon ministerial advice. ${ }^{257}$

However, the Constitution Act, 1867 did not create those constitutional conventions; instead, its provisions merely acknowledged the existence of well-established constitutional conventions that came into effect upon the grant of Responsible Government in the 1840s. Furthermore, the Colonial Office could only grant the United Province of Canada Responsible Government and all the constitutional conventions that this system entails after they had already evolved in the United Kingdom itself. Heard also notes that the various statutes through which Parliament delegates powers to the Governor-in-Council in practice mean that the Governor acts on and in accordance with the advice of Cabinet; however, this procedure of legislative drafting also takes into account well-established constitutional conventions that already exist, not new conventions that those specific statutes purport to have conjured up ex nihilo. All such constitutional conventions, however they emerge, remain subject only to political enforcement and are not justiciable.

Adam Dodek has argued that the true constitutional convention associated with minority parliaments in Canada is that the parliament must sit "for a reasonable length of time" - probably between six and twelve months - before the Governor General would accept the Prime Minister's advice to dissolve it. ${ }^{258}$ The $39^{\text {th }}$ Parliament lasted longer than most minority parliaments and met this test. Former Governor General Adrienne Clarkson recounted in her autobiography that "if [the Martin] government lasted six months, I would allow dissolution.",259 Dodek concluded, "[e]xisting constitutional conventions cannot be brushed aside so easily by a statute structured on the idea of a four-year fixed date but with a carefully drafted escape 
clause. $" 260$ Even Dodek's argument does not take into account all the principles at stake. This issue of how many months the minority parliament must live before early dissolution does not necessarily correspond to the presence of an alternative government within the existing assembly, which ought to be the most important consideration in determining whether a midparliamentary change of government or early dissolution is preferable.

For example, if a single-party minority government lost the confidence of the Commons, say, five months into the life of the parliament, and no alternative government existed within that House of Commons, the Governor General would still have to promulgate the Prime Minister's constitutional advice to dissolve parliament accordingly. And if a single-party minority government lost the confidence of the Commons six months, 12 months, 18 months, 2 years, or 3 years into the life of the parliament, the Governor General could, and probably should, first ascertain whether the Commons could support an alternative government before dissolving it on the Prime Minister's advice.

\section{Constitutional Conventions in Relation to Responsible Government and Dissolution}

Notwithstanding the principles of Responsible Government described in Section IV, Heard and Russell take a different view. Russell has argued, "Now that Parliament has indicated that elections should take place every four years, Governors General will not acquiesce so readily to Prime Ministers who seek an early election." ${ }^{261}$ In his affidavit in support of Democracy Watch's application, Russell argued "a fixed-date election law implies a change in the conventions governing the Governor General's power to dissolve Parliament."262 Curiously, Russell's formulation omits any reference to the Prime Minister and thus seems to place undue emphasis on the Governor General's discretionary authority. The Government rejected this claim because it failed to meet the threshold for determining the existence of a convention set up in Jennings's Test, which the Supreme Court endorsed in the Patriation Reference. ${ }^{263}$ British constitutional historian Sir Ivor Jennings proposed that a practice or custom should be regarded as a constitutional convention if it satisfies three questions: What are the precedents? Did the actors believe they were bound by a rule? Is there a reason for the rule? ${ }^{264}$

First, the early dissolution of the $39^{\text {th }}$ Parliament, coupled with a fixed-date election law, had no precedent in Canada before September 7, 2008. Up to that point, the provinces that had adopted fixed-date election laws (British Columbia, Newfoundland and Labrador, Ontario, New Brunswick, Saskatchewan, and Prince Edward Island) had faced only majority parliaments, which render early dissolution either improbable or unnecessary. Second, the only relevant actors with respect to the summoning, prorogation, and dissolution of Parliament are the Prime Minister and Governor General. Parliament does not play any role therein. Third, there is no reason why such a convention could exist. In fact, this alleged convention would violate the well-established constitutional principles of Responsible Government and the well-established constitutional positions of the Prime Minister and Governor General, as well as section 41(a) of the Constitution Act, 1982.

Heard criticized the Federal Court for having held that "the only relevant actors in dissolution are the Governor General and the Prime Minister" even though the Federal Court was, in fact, correct. ${ }^{265}$ Heard describes this conclusion as "problematic" and noted that the court 
focused mainly on Nicholson's statements and not Harper's. ${ }^{266}$ Responsible Government depends upon collective ministerial responsibility, individual ministerial responsibility, and cabinet solidarity $^{267}$, so both Prime Minister Harper and Attorney General Nicholson spoke for the same government with respect to the fixed-date election law. And the Prime Minister and the Governor General remain the only two relevant actors on dissolution because this law deliberately preserved their respective established constitutional positions within Responsible Government. ${ }^{268}$ Contrary to Russell's suggestion, the statute law does not allow the House of Commons to place itself between the Prime Minister and the Governor General with respect to dissolution or any other matter pertaining to the constitutional exercise of executive authority.

The Government argued that the Office of Governor General includes the authority over dissolution of Parliament by virtue of section 50 of the Constitution Act, 1867 and by section 6 of the Letters Patent Constituting the Office of Governor General of 1947; therefore, only a constitutional amendment under section 41(a) of the Constitution Act, 1982 could eliminate executive control over dissolution. The fixed-date elections law thus included the non-derogation clause that saved "the powers of the Governor General, including the power to dissolve Parliament at the Governor General's discretion" because it would otherwise have been ultra vires and unconstitutional. ${ }^{269}$ The Government also argued that since the Governor General exercises the Crown's power of dissolution on, and apart from exceptional circumstances, in accordance with, the advice of the Prime Minister, any limitation on the Prime Minister's capacity to advise dissolution "would likely constitute a fetter on the Office of the Governor General." 270 The Governor General may therefore dissolve parliament on the advice of the Prime Minister earlier than the prescribed date. ${ }^{271}$ The Government also pointed out to the Federal Court that the $39^{\text {th }}$ Parliament had survived longer than any previous "uninterrupted minority parliament" up to that date, at 937 days and that based on the "established constitutional conventions, Prime Minister Harper was entitled to request a dissolution on September 7, 2008, and Governor General Jean was obliged to grant his request." 272 The $14^{\text {th }}$ Parliament (19221925 ) lasted longer than the $39^{\text {th }}$, but King's Liberals oscillated between a parliamentary plurality and majority throughout due to the shifting allegiances of the Progressives.

By presenting a selective series of quotes from Prime Minister Harper and Justice Minister Nicholson, Conacher argued that the Harper government had created what Heard calls a "convention by agreement" such that the Prime Minister would no longer initiate early dissolution unless the Commons had first withdrawn its confidence from the Government. ${ }^{273}$ First, constitutional conventions do not arise by agreement in this manner - particularly not when they would directly violate other constitutional principles and section 41(a) of the Constitution Act, 1982. Second, Conacher omitted some of Nicholson's most crucial statements before the relevant Commons Committee. The Federal Court concluded, correctly, that "Hansard is ambiguous and does not establish an intention to bind the Prime Minister." 274 In reality, Hansard is deliberately ambiguous because the Harper government promoted a political narrative on how fixed-date elections would work in the Commons - meant for public and media consumption and reserved the more nuanced legal-constitutional argument for the parliamentary committees.

Heard later elaborated on the reasoning behind the Conacher rulings and argues that constitutional conventions could derive from four sources: historical customs and precedents, by mutual agreement, by unilateral declaration, and through principle. ${ }^{275}$ The better conclusion is 
that constitutional conventions derive from only two of these sources: historical customs and precedents and through principle. ${ }^{276}$ Heard argues that the fixed-date elections laws created constitutional conventions by agreement through the Harper government's stated intention. However, what Heard calls "conventions by agreement" amount to a lesser class of pledge or custom that falls below the threshold of a true constitutional convention. The Federal Court considered this argument but concluded that such "conventions by agreement" only occur on the international stage in negotiations "with the Commonwealth framework." 277 Heard disagrees and cites the resolutions of the Imperial Conferences of 1926 and 1930 (inter se negotiations within the Commonwealth framework) as well as the Meech Lake Accord while it pended ratification, which involved negotiations between the federal and provincial First Ministers.

These "conventions by agreement" act as temporary or transitional phases before the ratification of formal legal framework; they do not necessarily have to occur as inter se negotiations within the Commonwealth, as Heard points out. The Statute of Westminster, 1931 codified into the laws of the United Kingdom and of Canada many of the resolutions of those Imperial Conferences of 1926, 1929, and 1930, precisely because the Dominion Prime Ministers had negotiated them inter-governmentally as a preliminary stage before statutory ratification. ${ }^{278}$ Similarly, Prime Minister Mulroney's agreement to bind himself to section 4 of the Meech Lake Accord and only nominate Senators whom the provinces had chosen acted as a transitional phase. If the provinces had ratified the Meech Lake Accord, then this politically enforceable "convention" would have become a codified, legally enforceable provision of the Constitution of Canada and thus ceased to be a "convention." After the failure of the Meech Lake Accord, Mulroney "no longer felt obliged to act on provincial lists," 279 because the principle had become defunct when Newfoundland and Manitoba vetoed the proposed mega-constitutional amendment. Mulroney did not agree to appoint Senators upon the advice of provinces as a general principle, but only as a transitional measure until the provinces ratified the Meech Lake Accord. Adhering to such a custom thereafter could even be construed as subversive to the verdict of the provincial legislatures. Neither of these temporary, transitional measures amounted to constitutional conventions; at most, they amounted to matters of procedural convenience and lacked the underpinning of a constitutional principle.

Heard also argues that conventions can also come about "through authoritative unilateral declarations by key political actors." 280 These "conventions by declaration" in fact amount to individual policy preferences or self-denying ordinances, not a robust conventional convention that binds the office-holder's successors. What one Prime Minister can unilaterally impose, his successors can, just as arbitrarily, unilaterally undo. Even if conventions could arise by unilateral declaration as Heard suggests, then the constitutional constitution implied in the fixed-date election laws is precisely the opposite of what he argues because Prime Minister Harper and Premiers Wynne, Marois, Ghiz, Prentice, and MacLauchlan from 2008 to 2015 all affirmed that the fixed-date election laws have not derogated from the First Minister's capacity to advise and receive early dissolution. In this particular case, Heard's argument for convention by unilateral declaration works against his larger argument that Prime Minister Harper acted unconstitutionally in 2008.

Both the "convention by agreement" and "convention by declaration" arguments lack the necessity and permanence that underpins true constitutional conventions, such as the confidence 
convention and the core arrangement of Responsible Government. Heard also argues that "principled reasons are indeed essential to conventions" and that "conventions [...] arise to give practical form to basic constitutional principles." ${ }^{281}$ To elevate the Prime Minister's unilateral personal preferences and temporary, transitional customs to the level of "constitutional conventions" trivializes the true constitutional conventions that uphold Responsible Government and the democratic principle. These conventions support underlying principles and have remained largely intact since the nineteenth century; they do not fade in and out of fashion, nor do they depend upon the caprice of an individual Prime Minister. The conventions of Responsible Government emerged in order to maintain the infallibility of the Sovereign: the Queen still does no wrong because Ministers of the Crown, rather than the Queen, take responsibility for all acts of the Crown. ${ }^{282}$ The constitutional convention that Heard and Russell promote would contradict the basic principle of Responsible Government that Ministers of the Crown take responsibility for all acts of the Crown and that the Governor therefore acts on, and apart from exceptional circumstances, in accordance with, that ministerial advice.

Heard argues, "In the absence of any recognized convention, the fixed election date law would appear futile." 283 Heard is correct in his statement, but not in his implication that the law would therefore have to conjure up a new constitutional convention. Contrary to how federal and provincial governments across Canada presented this method of fixed-date election law as somehow limiting the First Minister's discretion, all these statutes are indeed futile, and worse than useless, because their alleged political enforceability and conventional force rely entirely upon mendacious political narratives. In reality, all fixed-date election laws in Canada have done is reduce the maximum life of the legislatures from five years to between four and five years; they certainly do not guarantee a minimum lifespan of legislatures.

\section{Conclusion}

Heard concludes, "it does appear that the Prime Minister broke a convention in securing an early election. The reasoning on this decision in Conacher is deeply flawed." ${ }^{284}$ Yet it is unclear what remedy Heard is advocating. After all, constitutional conventions - by definition remain only politically enforceable and are not legally enforceable in the courts. Even if they were legally enforceable, and if the courts had declared Prime Minister Harper in violation of a constitutional convention, they were in no position to offer a judicial remedy. In other words, the courts could not overturn the results of an election and engage in an unconstitutional and impracticable interference with the operation of the executive and legislative branches under Canada's separation of powers. If the courts had ruled that Prime Minister Harper acted incorrectly in 2008, then this declaration would have been both factually incorrect and a useless rhetorical exercise. An election held and a parliament convened cannot be undone by any mere mortal.

If Governor General Jean had rejected Prime Minister Harper's advice to dissolve the $39^{\text {th }}$ Parliament, she would have withdrawn her confidence and official commission of authority from Harper, who would in turn have had to resign as Prime Minister. Governor General Jean would then have had to appoint a new Prime Minister, who would then take responsibility for her refusal to dissolve parliament on Harper's advice and command the confidence of the House of Commons. Dodek has argued that if the Heard-Russell constitutional convention existed, then it 
would serve only to heighten the Governor's discretion to reject Prime Ministerial advice and indeed invite the Queen's representative to wield this augmented discretion in order to enforce the new constitutional convention. ${ }^{285}$ But even if this new constitutional convention existed, the Governor could only reject Prime Ministerial advice on dissolution if he could also appoint a new Prime Minister and alternative government from the existing parliament.

The "spirit" of these fixed-date elections laws springs from a false and disingenuous premise that a legislature can somehow create and codify a new constitutional convention into law by bypassing the amendment of the Constitution Acts, or that a selective and unrepresentative set of ministerial statements create a convention by agreement, or that one Prime Minister can unilaterally create a convention by declaration that binds his successors. These methods would conjure up contrived conventions and do nothing substantial. Prime Minister Harper therefore could have broken a non-existent constitutional convention, and he certainly did not break the law itself when he advised an early dissolution in 2008. And neither Premier Marois nor Premier Wynne in 2014 nor Premiers Prentice nor MacLauchlan in 2015 "broke the law" when they each advised the early dissolution of their respective provinces' legislatures.

\section{VIII: The Aftermath of the Federal General Election of 2015: Imposing Both a Minimum and Maximum Duration of the Writ}

Canadian fixed-date election laws do not create stable terms of four years, not merely because the governor can dissolve the legislature early on the advice of the First Minister, but also due to the fact that they all schedule elections for the same month in a calendar year, like October, instead of providing that the next election should occur four years after the return of writs for the previous election. As such, the schedules then start providing for terms of longer than four years if the previous parliament did not dissolve in the right month. For instance, in March 2011, the House of Commons of the $40^{\text {th }}$ Parliament withdrew its confidence from the Harper government, which necessitated a dissolution earlier than in anticipation of a general election in October 2012. Instead, a general election occurred on 2 May 2011. The following federal election therefore occurred in October 2015 rather than precisely four years later in May 2015, and the $41^{\text {st }}$ Parliament lasted four and a half years under the fixed-date election law rather than four years.

In the second half of 2014, the media devoted great speculation as to whether Prime Minister Harper might decide to advise an early dissolution the spring of 2015 rather than waiting until the scheduled date in October $2015 .{ }^{286}$ Ironically, "breaking" the fixed-date election law in this manner would better conform to the "spirit" of the law than allowing this $41^{\text {st }}$ Parliament to live until October 2015. In the end, the schedule for the federal general election in October 2015 held - but no one anticipated that Prime Minister Harper would opt for an extended writ of over two months. Instead of advising the dissolution in early September 2015 for a writ of 36 to 40 days, Harper did so on 8 August 2015 instead, and the $42^{\text {nd }}$ general election lasted a near-record 78 days. ${ }^{287}$ This abnormally long writ in 2015 also generated controversy not unlike that from September 2008 and also led to the inaccurate charge that Harper once again had "called an early election." 
The fixed-date election law played a part in this long writ in the general election of 2015, the first to occur as scheduled under 56.1 of the Canada Elections Act. These laws across Canada have, in effect, made the preceding six months before the scheduled election a de facto pre-writ campaign period, so it was not unreasonable to make the de facto pre-writ a de jure writ through a longer formal election.

Section 57(1.2)(c) of the Canada Elections Act regulates the writs of election and mandates that the writ period must last, at minimum, 36 days.

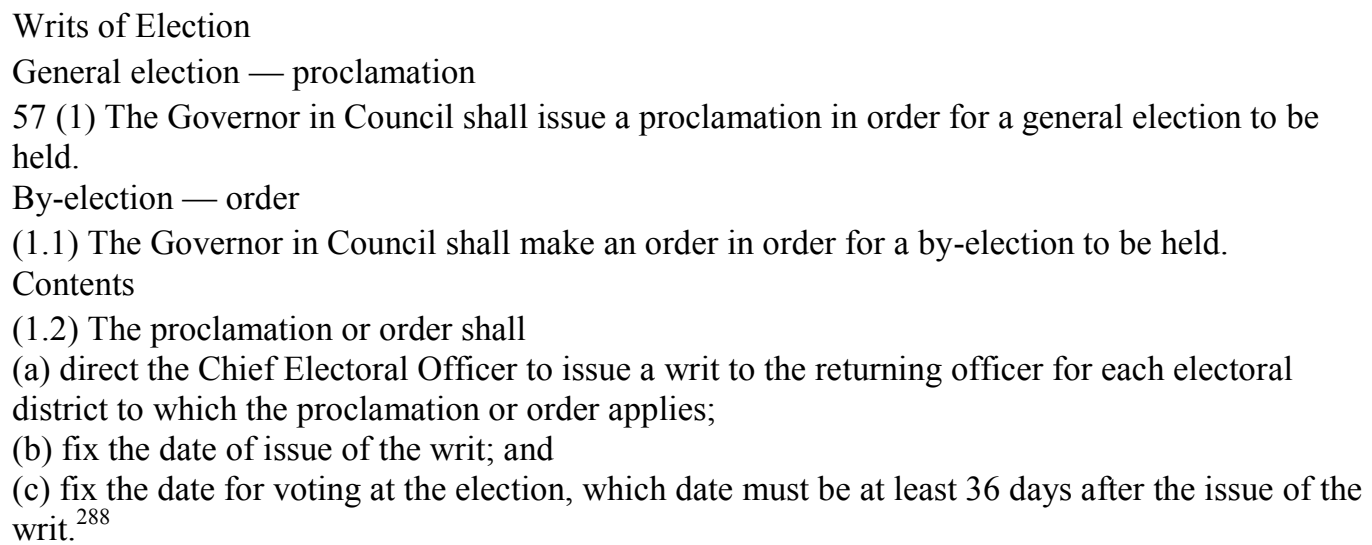

However, as of September 2018, the Act still places no limit on the maximum duration of the writ period, which remains at the discretion of the Prime Minister and cabinet. In light of the $42^{\text {nd }}$ general election - the longest since the mid- $19^{\text {th }}$ century - New Democrat MP Alistair MacGregor introduced a bill that would also prescribe a maximum writ of 46 days. ${ }^{289}$

57 (1) The Governor in Council shall issue a proclamation in order for a general election to be held.

1.2 The proclamation or order shall

(a) direct the Chief Electoral Officer to issue a writ to the returning officer for each electoral

district to which the proclamation or order applies;

(b) fix the date of issue of the writ; and

(c) fix the date for voting at the election, which date must be at least 36 days after the issue of the writ. $^{290}$

In principle, if parliament is competent to set the minimum number of days of the writ, then it could also specify a maximum duration of the writ because, in both cases, the statute law regulates the exercise of the Crown's authority at the margins and does not substantially alter it. Notwithstanding how the Canada Elections Act regulates the duration of the writ, only the Governor General, on the advice of the Prime Minister or cabinet, can issue the executive instruments for summon, proroguing, and dissolving parliaments. If, however, parliament or a provincial legislature wanted to pass legislation like the Fixed-Term Parliaments Act, 2011, they would find themselves ultra vires of section 41(a) of the Constitution Act, 1982, because only a constitutional amendment under that unanimity formula could abolish the authority of the Crown to summon, prorogue, or dissolve parliament or a legislature.

In June 2018, the Trudeau government incorporated MacGregor's idea into Bill C-76, the Elections Modernization Bill. If passed, the Canada Elections Act would stipulate by a minimum 
and a maximum duration of the writ, and it would also create a new set of rules limiting spending and advertising during the "pre-election period" from 30 June in the years of scheduled general elections until the day before dissolution - both of which seems like a reasonable means of regulating the pre-writ in an era where fixed-date elections have given this period new relevance. $^{291}$ They exemplify the layering which has characterized the entire practice of Canadian fixed-date election laws, both from their original incarnations in the nine provinces that adopted them and in the six provinces which have subsequently amended their statutes. Section 57(1.2)(c) would therefore say the following:

(c) fix the date for voting at the election, which date must be no earlier than the $36^{\text {th }}$ day and no later than the $50^{\text {th }}$ day after the day on which the writ was issued.

The new "pre-election period" would, of course, only apply when the government and parliament adhere to the fixed-date elections scheduled under section 56.1 of the Canada Elections Act, because the pre-writ, by definition, can only become a well-defined and meaningful period when the approximate date of dissolution and the date of the general election are known well in advance.

pre-election period means the period beginning on the June 30 before the day set in accordance with subsection 56.1(2) for the holding of a general election and ending on the day before the earlier of

(a) the first day of an election period for a general election, and

(b) the 37th day before the Monday referred to in subsection 56.1(2) or, if the Governor in Council makes an order under subsection 56.2(3), the 37 th day before the alternate day referred to in that order. $^{292}$

In other words, these new provisions pertaining to the "pre-election period" would not and could not, by definition, apply during snap elections. These increasingly common de facto pre-writ campaigns have already started to raise questions on when or whether the incumbent government should engage in the Principle of Restraint, also known as the Caretaker Convention, and restrict government activity during the summer to routine business. ${ }^{293}$ The Privy Council Office devised some guidelines for internal use on the caretaker convention in 2008 and published the second edition online in 2015. They say:

[D]uring an election, a government should restrict itself - in matters of policy, expenditure and appointments - to activity that is: a) routine, or b) non-controversial, or c) urgent and in the public interest, or d) reversible by a new government without undue cost or disruption, or e) agreed to by the Opposition (in those cases where consultation is appropriate). ${ }^{294}$

Peter Russell and Carl Baar took the extreme and impractical view that no government should be allowed to "make order-in-council appointments to positions that will not be open until after an election" and that we should "establish a new constitutional convention" to that effect. ${ }^{295}$ Of course, constitutional conventions are, by definition, not designed or created; instead, they evolve organically over time. Conventions can be recognized to exist, but they cannot be proclaimed into existence. Baar and Russell also intimate that the Trudeau government should formally rescind these Governor-in-Council appointments instead of simply asking some appointees to resign. Only New Zealand has thus far taken the view that the Caretaker Convention should kick in before the writ; its Cabinet Manual states that governments should not engage in non-routine advertising up to 90 days before the writ, but it remains silent on appointments. ${ }^{296}$ 


\section{IX : Provincial Fixed-Date Election Laws in Canada, 2001-2018}

\section{$\underline{\text { British Columbia }}$}

In the provincial election of 2001, the BC Liberals under Gordon Campbell campaigned on fixed-date elections as part of a broader set of political reforms aimed at opening up government and promoting direct democracy, views which the BC Liberals shared with the Reform Party and its successor, the Canadian Alliance. For instance, they promised "to introduce free votes in the legislature [...] on all matters not specifically identified as a vote of confidence," as well as to "establish a fixed date for the tabling of the provincial budget, and a set legislative calendar," and to strengthen the Initiative and Recall Act. ${ }^{297}$ They also promised to introduce legislation for fixed-date elections every four years. The Campbell government followed through: after winning a massive parliamentary majority in 2001, it pioneered a model of fixeddate elections that all that other Canadian jurisdictions emulated over the next decade.

British Columbia has partially codified its provincial constitution by renaming what most other provinces call their "Legislative Assembly and Executive Council Acts" into a Constitution Act and includes its fixed-date election provision therein. ${ }^{298}$ Also unlike most of the other provinces and the federal level, British Columbia's legislation contains a substantive clause affirming the Lieutenant Governor's power rather than a non-derogation clause per se, though the effect is identical. Section 23(1) preserves the powers of the Crown:

Lieutenant Governor may, by proclamation in Her Majesty's name, prorogue or dissolve the Legislature when the Lieutenant Governor sees fit.

Section 23(2) originally set out fixed-date elections on the second Tuesday in May every four years, starting in 2005. British Columbia has since held scheduled elections in 2009, 2013, and 2017.

In 2001, Attorney General G. Plant described the bill at First Reading as "ensur[ing] that provincial elections must be held on a fixed date every fourth year or immediately if a government loses a confidence vote. ${ }^{, 299}$ At Second Reading, he reiterated that the bill "preserves the constitutional prerogative of the Lieutenant Governor to prorogue or dissolve the Legislative Assembly" so that the "Lieutenant-Governor may dissolve the Legislative Assembly and call a general election immediately" if the government loses the confidence of the assembly. ${ }^{300}$ In reality, a loss of confidence only necessitates an early dissolution if there is no viable alternative government within the assembly. He also declared that the law would "take some of that power [to dissolve the Legislative Assembly] out of the Premier's office" ${ }^{, 301}$ - precluding the possibility of a mid-parliamentary change of government that would also involve a transfer of power between parties.

However, a mid-parliamentary, intra-party change of government did occur on 30 May 2011 when Christie Clark became Premier half way through the life of the $39^{\text {th }}$ Legislature. Gordon Campbell had served as Premier from 2001 to 2011 but faced enormous opposition after he implemented the Harmonized Sales Tax (HST) despite having promised the contrary during the election campaign of 2009. ${ }^{302} \mathrm{He}$ announced his intention to resign in November 2010 before British Columbians voted on a citizen-initiated referendum to repeal his policy decision to adopt 
the HST. Notwithstanding the fixed-date elections law, some New Democratic MLAs in opposition called upon Premier Clark to advise an early dissolution. ${ }^{303}$ New Democratic MLA Mr. Leonard Krog argued that the new Liberal Premier "needs to call a general election." Fellow New Democratic MLA Norm Macdonald agreed. Macdonald stated that his constituents expressed an "expectation of another election." 304 While the Liberal leadership race was still underway, he argued that Premier Gordon Campbell's replacement as Liberal party leader and Premier should call an early election because "governments need mandates." Finally, New Democratic MLA Bob Simpson tabled a bill to move fixed-date elections from the spring to the fall and to hold the first fall election in October 2012. ${ }^{305}$ The New Democrats would revive this idea once they formed government again five years later.

This case demonstrates that Governments could sometimes take advantage of a fixed-date election law in order to insulate themselves from widespread public opposition to their policies, while other time the Opposition prefers a snap election in order to take advantage of the Government's declining poll numbers. ${ }^{306}$ And sometimes mid-parliamentary, intra-party transfers of power from one Ministry to another could warrant an early dissolution. Interestingly, if British Columbia had adopted Newfoundland and Labrador's variant of the law, Clark would have been obliged to advise an early dissolution.

In 2017, the minority government of New Democratic Premier John Horgan introduced a bill that would switch the British Columbia's scheduled elections from every fourth May to every fourth October instead. ${ }^{307}$ In so doing, the Horgan government has extended the life of the current $41^{\text {st }}$ Parliament by five months, and thus potentially also extended the life of his tenuous minority government for the same amount of time. Similarly, the Selinger government in Manitoba ended up increase both the life of the $40^{\text {th }}$ Legislature (October 2011 to April 2016) and its own tenure in office, since the New Democrats lost the election, and the Wall government in Saskatchewan did likewise for the $27^{\text {th }}$ Legislature, which also lived from November 2011 to April 2016.

Attorney General David Elby stated that re-scheduling provincial general elections from the second Tuesday in May to the third Saturday in October would "increase transparency" by allowing for the passage of a budget before the election. ${ }^{308}$ Lisa Beare, the Minister of Tourism, Arts, and Culture, added: "Moving the election date to the fall leaves time for a February budget to be debated and passed. The people of British Columbia will know the status of our province's finances and will be able to vote accordingly." 309 The Liberal opposition did not object to switching the scheduled from May to October per se - but it very much objected to extending the life of the $41^{\text {st }}$ Parliament. Liberal MLA Andrew Wilkinson argued that the bill should have scheduled the next election for October 2020 rather than October 2021 and accused the Horgan government of perpetuating an anti-democratic mandate:

\footnotetext{
Surely in a democracy like ours, the party currently in power by the skin of its teeth with the assistance of the Green Party should not be granting itself an extra six months during which it will spend \$26 billion of taxpayers' money by simply granting itself a six-month extension in the Legislature. This is fundamentally undemocratic. The most obvious solution to this is simply to reset the date, if it's going to be in October, to October of 2020 rather than October of $2021 .^{310}$
}

Wilkinson also asserted - quite incorrectly - that "every jurisdiction in Canada" has operated on elections scheduled every four years instead of every four and a half years, 
describing the latter as a scheme "dreamt up by the NDP to grant themselves an extra \$26 billion of spending power and an extra six months in office." 311 He later denounced this change as "unprecedented in Canadian history." 312 In fact, three Canadian jurisdictions - Manitoba, Saskatchewan, and Prince Edward Island - had by 2017 deliberately planned to extend the lives of at least one of their legislatures by six months or so in order to prevent scheduled federal and provincial elections from overlapping, and three Canadian jurisdictions by 2017 - Manitoba, Saskatchewan, and Ottawa - had actually seen legislatures last four and a half years instead of four. The $41^{\text {st }}$ Parliament of Canada lived longer than four years because the previous $40^{\text {th }}$ Parliament had dissolved in March instead of October. And the legislature of Newfoundland and Labrador in 2015 voted to extend its life by a few weeks so that the provincial and federal elections of that year would also not overlap. Wilkinson alluded to the precarity of the minority Horgan government, which the Greens supported as part of a supply agreement. Andrew Weaver, Leader of the Green Party, spoke in favour of the bill and pointed out that while holding the election in October 2021 would increase the life of the current legislature to close to four and a half years, it would provide the Horgan government the opportunity to remain in office for closer to four years, given that the Lieutenant-Governor appointed Horgan as Premier midparliament rather than immediately after the previous general election. ${ }^{313}$

Liberal MLA John Rustad introduced an amendment that would have rescheduled the next provincial election October 2020, instead of October 2021. ${ }^{314}$ The New Democrats and Greens voted it down, and Attorney General Elby argued that British Columbia was simply following the precedents established by the previous legislatures of Manitoba and Saskatchewan, which had also extended their lives to four and a half years. ${ }^{315}$ It should be noted, however, that the Horgan government's bill did indeed set the first precedent on extending the life of legislature in the absence of any potential for overlapping federal and provincial elections and that it also marked the first time that a minority government had tabled such a bill. Perhaps more legitimately, Wilkinson also raised concerns that scheduling elections on a Saturday would violate the religious freedom of observant Jews and Seventh-Day Adventists. ${ }^{316}$ Minister Beare responded that an amendment to the provincial Election Act would provide for six days of advanced polls on all other days of the week and that holding elections on Saturdays would increase voter turnout. ${ }^{317}$

Finally, British Columbia's new legislation built upon the ad hoc amendments of Manitoba, Saskatchewan, Prince Edward Island, and Newfoundland and Labrador and introduce a novel element. British Columbia's updated fixed-date election law provides for delaying the scheduled provincial election if it would otherwise overlap with the scheduled federal election and - unlike the others - if it would overlap with scheduled municipal elections within the province. Instead of declaring an exact date to which the provincial election would be delayed as the legislation in Manitoba, Saskatchewan, Prince Edward Island, and Newfoundland and Labrador does - it instead postpones the election until an unspecified date that the Premier would determine "after consulting the Chief Electoral Officer, the Leader of the Opposition and each leader of a recognized political party" until, potentially, the legislature's absolute maximum lifespan of five years under section 4(1) of the Constitution Act, 1982. In other words, if and only if a general federal election or municipal elections were held in October 2021, it would be possible to extend the life of the $41^{\text {st }}$ Parliament all the way to 11 April 2022. Of course, "consultation" in this statute does not give the Leader of the Opposition or the leader of any 
other recognized political party a veto on the Premier's decision. But within the $41^{\text {st }}$ Parliament of British Columbia, this does codify a formal role for Green Party Leader Andrew Weaver especially since this Bill 5 also made the Greens an official parliamentary party by lowering the threshold for official party status in the legislative assembly from four to two MLAs.

In effect, that provision codifies part of the supply agreement between John Horgan's minority New Democratic government and Andrew Weaver's Greens on "Consultation Arrangements." ${ }^{318}$ Attorney General Elby touted this provision as ensuring transparency. ${ }^{319}$ Aside from any political implications in this current legislature, British Columbia's bill has avoided the problem that Saskatchewan's Chief Electoral Officer has highlighted, whereby the writ of Saskatchewan's next scheduled provincial election in November 2020 will overlap with that province's scheduled municipal elections.

The Constitution Act of the province now provides for the following schedule of general elections:

General elections

23 (1)The Lieutenant Governor may, by proclamation in Her Majesty's name, prorogue or dissolve the Legislative Assembly when the Lieutenant Governor sees fit.

(2)Subject to subsection (1), a general voting day must occur on the third Saturday in October in the fourth calendar year following the general voting day for the most recently held general election.

(3)As an exception to subsection (2), if the campaign period for a general election to be held under that subsection would overlap with the campaign period for a general local election to be held under section 52 of the Local Government Act or the election period for a federal general election to be held under section 56.1 (2) or section 56.2 of the Canada Elections Act, the general voting day for the general election must be held instead on a date to be specified under the Election Act that the Lieutenant Governor in Council determines to be suitable after consulting the Chief Electoral Officer, the Leader of the Official Opposition and each leader of a recognized political party.

(4)In this section, "general election" and "general voting day" have the same meaning as in section 1 of the Election Act.

The next election is now scheduled to occur in October 2021. But it would occur sooner if Horgan's minority government loses the confidence of the assembly, which has already withdrawn its confidence of the Clark government in June 2017 and therefore exhausted all its options.

\section{$\underline{\text { Newfoundland and Labrador }}$}

Newfoundland and Labrador passed the second fixed-date elections law in Canada in 2004 by amending its House of Assembly Act and Elections Act. ${ }^{320}$ Section 3(1) includes a standard non-derogation clause that preserves the established constitutional position of the Premier and Lieutenant-Governor:

3(1). Notwithstanding subsection (2), the Lieutenant-Governor may, by proclamation in Her Majesty's name, prorogue or dissolve the House of Assembly when the Lieutenant-Governor sees fit. $^{321}$ 
Section 3(2) sets the fixed election every second Tuesday in October, starting in 2007. Newfoundland held its second election pursuant to the fixed date in 2011. (The province ended up delaying its election in 2015 from October to November).

The law then adds a unique - and probably unconstitutional - innovation in section 3.1, "Election on change of Premier." The law could turn a political issue into a constitutional issue and potentially even into a constitutional crisis. This law springs from the view that a Premier appointed mid-parliament should have to "seek his own mandate" from the electorate in an early general election because this is more "democratic."

3.1 Where the leader of the political party that forms the government resigns his or her position as leader and as Premier of the province before the end of the third year following the most recent general election, the person who is elected by the party to replace him or her as the leader of the party and who is sworn in as the Premier of the province by the Lieutenant-Governor shall, not later than 12 months afterward, provide advice to the Lieutenant-Governor that the House of Assembly be dissolved and a general election be held. ${ }^{322}$

In 2004, Ed Byrne, the Minister responsible for the bill, described section 3(1) as "eliminating the snap elections of the past;" he added that section 3.1 means that any new Premier appointed mid-parliament "must, within a twelve-month period - not may, but must - go to the people of the Province to seek their own mandate." 323 Jack Harris, then the Leader of the provincial New Democratic Party and later a federal New Democratic MP, argued that the mandated early dissolution "is not really required" and represents "more of a political issue" than a constitutional one. ${ }^{324}$ In Canadian law, shall is imperative and therefore means must, as Minister Byrne said. ${ }^{325}$ The law mandates that the Premier advise the Lieutenant Governor to dissolve the Assembly and thus infringes upon the constitutional relationship between the two. A statute law can no more forbid the Premier from advising the Governor to dissolve the assembly than it can force the Premier to advise the Governor to dissolve the assembly. This is what Canadian lawyer John Pepall has called causing the Premier to provide the Lieutenant Governor with "insincere and dishonest advice.",326

Most interestingly of all, this section 3.1 is not subject to the non-derogation clause of section 3(1), which only applies to section 3(2). Under section 3(1), the Premier may advise an early dissolution, but under section 3.1 , he or she must advise an early dissolution.

Newfoundland and Labrador's law therefore preserves the Premier's discretion to advise an early dissolution, as do all the other fixed-date election laws, but it would prevent a Premier appointed mid-parliament from serving for the remainder of that parliament. Section 3.1 means that, as those New Democratic MLAs in British Columbia argued, a Premier appointed mid-parliament should advise an early dissolution in order seek his or her own "mandate" from the electorate. This troublesome provision also raises the spectre of judicial review or vice-regal activism: what would happen if the new Premier appointed mid-parliament refused to advise the Lieutenant Governor to dissolve the House of Assembly early? The law compels the Premier to offer the Lieutenant Governor certain advice but does not specify what would happen if he did not. The courts would perhaps have to order the Premier to advise an early dissolution because the provision does not otherwise provide for an automatic dissolution by efflux of time as section 50 of the Constitution Act, 1867 does. Alternatively, the Lieutenant Governor would have to dismiss this Premier and appoint another who would advise the early dissolution pursuant to the law. 
John Pepall characterized the provision as "a grotesque corruption of the constitution only possible from wilful refusal to understand it., 327

Pepall has also noted that the law does not make provision for a Premier and party leader ousted by cabinet or caucus, for a Premier who dies in office, for a Premier who is dismissed by the Lieutenant Governor, or for a Premier who becomes incapacitated. ${ }^{328}$ The law could have avoided this ambiguity and the problematic omission of dismissal and death in office by remaining silent on the outgoing Premier and the manner of his or her resignation or dismissal, and instead focus exclusively on the incoming Premier. For instance, the law could have specified that "upon a change in Premier," the new Premier give certain advice, instead of opting for the ultra-specific clause, "where the leader of the political party that forms the government resigns his or her position as leader and as Premier [...]." While this would still be unconstitutional, it would at least maintain the virtue of covering a greater array of possible situations.

This oversight in the law might have contributed to the recent and unusual transfer of power in Newfoundland and Labrador. On 22 January 2014, Kathy Dunderdale announced that she would resign as Premier of Newfoundland and Labrador, after the chairperson of the Progressive Conservative caucus crossed the floor to the Liberals, and amidst allegations that she had mishandled the government's response to a series of power outages over the holiday season. ${ }^{329}$ Normally, the outgoing Premier would not formally tender her resignation until after the party had held a leadership convention and elected a new leader. But the Progressive Conservative Party of Newfoundland and Labrador took the unusual step of forcing Kathy Dunderdale's immediate resignation as party leader, and therefore also as Premier, so that the Lieutenant Governor could appoint the Finance Minister, Tom Marshall, as "Interim Premier." Marshall insisted, however, that he does not regard himself as a caretaker Premier and would thus not limit himself to routine administration. This decision both reflects the fact that "interim Premier" is a purely political convenience and has no bearing whatever on the legalconstitutional position of the Premier as head of government and the Ministry within the province.

Strictly speaking, Premier Dunderdale did "resign," but she did not follow the normal Canadian custom of remaining on as party leader and Premier until the party elects her successor. The law remains ambiguous and does not take into account the differences between situations where the parliamentary party ousts its leader and the Premier, as with Premier Dunderdale, versus those where the incumbent Premier resigns voluntarily, as Premier Danny Williams did. The self-styled "Interim Premier" Marshall indicated that he would only serve as Premier for "a few months," after which he would resign the leader of the Progressive Conservative Party and the Premiership in favour of whomever the party selected as its new leader. That leadership convention, originally scheduled for July 2014, was delayed until September $2014 .{ }^{330}$ On 13 September 2014, the Progressive Conservative Party elected Paul Davis as leader ${ }^{331}$; after a transition of 13 days, Marshall resigned, and the Lieutenant Governor appointed Paul Davis as Premier on 26 September 2014. ${ }^{332}$

This series of successive Premiers - from Premier Dunderdale's resignation on 24 January 2014 to Marshall's tenure as “Interim Premier" to Paul Davis's appointment as Premier 
on 26 September 2014 - raises some implications for Newfoundland and Labrador's fixed-date election law. Section 3.1 states that a new party leader and Premier must advise the Lieutenant Governor to dissolve the legislature within twelve months only if he or she is appointed "before the end of the third year following the most recent general election." In this case, that timeframe would apply to a Premier appointed before October 2014, given that the last provincial general election occurred in October 2011 and that the next had originally been scheduled for October 2015. But it remained unclear whether the point of reference for this requirement hinged upon Tom Marshall's appointment on 24 January 2014, or, rather, upon Paul Davis's appointment on 26 September 2014.

In other words, there remained some ambiguity whether Davis inherited Marshall's nine months such that he would have to have advised an early dissolution within three months of his appointment or 12 months. Newfoundland and Labrador's faulty fixed-date election law did not account for all the possible types of transitions from one Ministry to another. Under the first interpretation, Premier Davis would have needed to advise an early dissolution by January 2015 for an election in February or March 2015. However, the better answer was probably that Marshall's resignation reset the timeline and would have given Davis 12 months, or to September 2015, which, in turn, would have seemed almost pointless and redundant given that the election had originally been scheduled for only one month later, in October 2015, anyway. A second further problem would have arisen if the legislature had not intervened in 2015: the overlap with the federal general election that took place as scheduled in October 2015. The actions of the Davis government suggest that it found the latter interpretation more persuasive as well.

All of these inconsistencies and contradictions added up and persuaded the Davis government to intervene by tabling a bill to amend the fixed-date election law, replicating the precedents that Manitoba, Saskatchewan, and Prince Edward Island had already undertaken to avoid making their provincial elections overlap with the federal election in 2015. In June 2015, Premier Davis announced that his government would table a bill to postpone the fixed-date election to November in order to prevent any overlap with the federal election and to reduce the size of the House of Assembly to 40 members. But section 3.1 presented unique complications and considerations.

The Chief Electoral Officer, Victor Powers, had sent the leaders of all parties a letter outlining how Elections Newfoundland and Labrador could accommodate the reduction in the size of the legislature and alter the schedule of the next general election; he said that the agency could prepare itself to administer an election "by about the middle of August." 333 However, Powers based that timeline on the presumption that the federal general election would occur on schedule in October 2015 and - crucially - that it would see a standard, minimum writ beginning "near the middle of September." 334 In all probability, none of these MHAs and officials in Newfoundland and Labrador could have known in June 2015 that Prime Minister Harper would opt for the second-longest writ in Canadian history, going from early August until the election in October. Ultimately, this means that the Davis government made the right decision, whether by coincidence or by design. Powers also strongly cautioned against holding the provincial general election concurrently with the federal general election, including their respective writ periods, not merely the election days themselves: 
Conducting a provincial election which may overlap with the federal election period could lead to many logistical issues for the public, the parties, the candidates and election officials. Voters would be receiving information from Elections NL and Elections Canada at or about the same time informing them on how, where and when to vote, the locations of returning offices, etc. ${ }^{335}$

In Canada, where our federal and provincial political parties (with the exception of the New Democratic Party) maintain entirely separate organizations, we simply do not conduct simultaneous federal and provincial elections. We also tend to eschew conducting provincial and municipal elections at the same time.

On 4 June, Dwight Ball, then the Liberal opposition leader, argued that Premier Davis should opt for a provincial election in September and accused him of "trying to push the election out to November for [his] own purposes." ${ }^{, 336}$ Premier Davis countered that "it would be prudent to have the provincial election after the federal election" because the federal election would require a minimum writ of five weeks and therefore start around Labour Day. ${ }^{337}$ Ball then accused Premier Davis of having violated the spirit of section 3.1 and asked him whether the upcoming legislation would "cancel the law that requires you to call an election within one year of being sworn in." ${ }^{" 338}$ In fact, the bill did not propose to repeal section 3.1 in general but merely suspend its application to Premier Davis in particular. The Davis government introduced the bill at First Reading on 9 June 2015, and it went to Second Reading on 16 June. ${ }^{339}$

Liberal MP Jim Bennett, a lawyer by training, argued from the principle of the rule of law that "The Roger Grimes Law" contained in section 3.1 should be repealed outright and that the bill should not simply provide arbitrary dispensation or a personal exemption from that provision to Premier Davis alone. ${ }^{340}$ Bennett refers to section 3.1 as "The Roger Grimes Law" throughout, presumably because the Williams government had initialled pushed for this provision in 2004 as a reaction as former Liberal Premier Roger Grimes, who became Premier after a midparliamentary appointment and served in the office for well over two years before the next provincial general election. Bennett correctly pointed out that only "one person in this province is bound by the law [section 3.1 of the House of Assembly Act], which they call the "Grimes Law,' and that is the Premier," and he asked the government again why this bill would merely "put in abeyance" the Grimes Law for Premier Davis instead of repealing it entirely. ${ }^{341}$ Bennett also noted that if the government's bill had said nothing about "The Grimes Law," then section 3.1 would have obliged Premier Davis to advise the Lieutenant-Governor to dissolve the legislature for an election in October - and this would overlap with the federal general election. ${ }^{342}$ He therefore accepted the fact that something about section 3.1 had to change, but he would have preferred that the bill repeal it rather than grant one Premier a stay of execution.

The bill did also include the same ad hoc proviso - now rapidly becoming the new norm - that Manitoba pioneered and Saskatchewan and Prince Edward Island later adopted which allows the Premier to delay the provincial general election if it would otherwise overlap with the scheduled federal general election. (Quebec's law adopted a similar clause acknowledging both federal and municipal elections from the outset in 2013). However, unlike the equivalent provisions in Manitoba, Saskatchewan, and Prince Edward Island, which delay the provincial election by six months, from the fall to the following spring, Newfoundland and Labrador's would only delay the provincial election by a few weeks, from the second Tuesday in October to the last Monday in November. Section 3(4) stipulates that the Premier would have to make this 
decision by 1 April of the year in which the election is scheduled. In all probability, Premier Ball will have to invoke this provision in 2019, because the provincial election currently scheduled for October 2019 will overlap with the federal general election also scheduled for October 2019.

By 1 April 2019, Premier Ball will have to announce that the provincial election will be delayed from October 2019 to November 2019. And this will reveal another problem: that as long as the Canadian federal elections and Newfoundland and Labradorean provincial election remain scheduled for the same time - every fourth October - then they will continue to overlap in 2019, 2023, and so on, which means that Newfoundland and Labrador will, in turn, have to continue delaying its elections from October to November in perpetuity. Therefore, Newfoundland and Labrador's best option would be to amend section 3(2) and move the scheduled election to a new timeframe, such as, say, from October to June, as Ontario did in 2016.

Finally, this new method of delaying scheduled provincial elections that Manitoba, Saskatchewan, Prince Edward Island, Quebec, and Newfoundland and Labrador have all adopted comes with yet another side-effect in the 2010s not intended by those who originally foisted fixed-date election laws upon Canadian jurisdictions in the 2000s: creating a clearly-defined and contentious pre-writ. In Manitoba and Saskatchewan, the pre-writ for the elections in April 2016 effectively lasted six to nine months, because the Premiers had to announce well in advance that they would abide by the legislation and advise the Lieutenant-Governors to dissolve the provincial legislatures late. Newfoundland and Labrador's new legislation all but guarantees that that the pre-writ for the provincial election of 2019 will now last at least six months, from 1 April 2019 until dissolution in late October 2019. This, in turn, could necessitate the provinces following Ottawa's lead and passing new laws regulating political activity in a defined pre-writ.

The Davis Dispensation in section 3(3) became defunct after the provincial election of November 2015, but it remains in the text of the act like an archaeological artefact or genetic atavism. The regular provision for delaying a provincial general election resides in section 3(4). Sections 3 and 3.1 of the House of Assembly Act now read as follows.

Duration of House of Assembly

3. (1) Notwithstanding another provision of this section, the Lieutenant-Governor may, by proclamation in Her Majesty's name, prorogue or dissolve the House of Assembly when the Lieutenant-Governor sees fit.

(2) A polling day at a general election shall be held on the second Tuesday in October, 2007 and afterward on the second Tuesday in October in the fourth calendar year following the polling day at the most recently held general election.

(3) Notwithstanding subsection (2) and section 3.1, the polling day for a general election in 2015 shall be held on November 30, 2015.

(4) Notwithstanding subsection (2), if, on April 1 in the year that a general election is to be held under that subsection, the Premier is of the opinion that the day that would be an ordinary polling day under that subsection is not suitable for that purpose because it overlaps with a federal election, the Premier shall choose an alternative day in accordance with subsection (5) and shall provide advice to the Lieutenant-Governor that a general election be held on that alternative day. (5) The last Monday in November in the fourth calendar year following the ordinary polling day for the most recently held general election is the alternative day referred to in subsection (4). ${ }^{343}$ 
Election Upon Change of Premier

3.1 Where the leader of the political party that forms the government resigns his or her position as leader and as Premier of the province before the end of the third year following the most recent general election, the person who is elected by the party to replace him or her as the leader of the party and who is sworn in as the Premier of the province by the Lieutenant-Governor shall, not later than 12 months afterward, provide advice to the Lieutenant-Governor that the House of Assembly be dissolved and a general election be held.

The Davis government's bill should have repealed section 3.1 outright instead of simply cancelling its application to Premier Davis alone through an ad hoc proviso; the provision is at best ambiguous and confusing and at worst is unconstitutional and ultra vires of section 41(a) of the Constitution Act, 1982. His own Premiership perfectly illustrates the political and practical problems that it can cause as well. The new Liberal government of Premier Ball should - and probably will have to - introduce another bill to amend the House of Assembly Act in light of the other logistical problems highlighted above. This bill will have to deal with the permanent overlap between the scheduled federal and provincial general elections by moving Newfoundland and Labrador's scheduled elections to a different month, and it should probably also devise new regulations on political advertising during the pre-writ, thus building on recent legislation in Ontario and Ottawa.

\section{$\underline{\text { Ontario }}$}

Ontario adopted its fixed-date elections law in 2005, and it follows the standard Canadian model. Section 9(1) of Ontario's Elections Act states:

9(1) Nothing in this section affects the powers of the Lieutenant Governor, including the power to dissolve the Legislature, by proclamation in Her Majesty's name, when the Lieutenant Governor sees fit. $^{344}$

Section 9(2) originally set fixed-date elections on the first Thursday in October in 2007 and "thereafter, general elections shall be held on the first Thursday in October in the fourth calendar year following polling day in the most recent general election." In 2005, Michael Byrant, the Minister responsible for the bill, told the Assembly that the bill would abolish "the right of the Premier to call elections based on partisan and political considerations." 345 New Democratic MPP Peter Kormos challenged the Dalton McGuinty Government's claim - and until MNAs in Quebec debated their bill in 2013, he may have been the only elected representative in the entire country to articulate the correct argument against the Canadian model of fixed-date elections. Mr. Kormos derided the bill as "purport[ing] to create fixed-date elections dates," given that the Constitution Act, 1982 already sets fixed-date elections by limiting the legislature to a maximum life of five years and that the bill preserves the established constitutional positions of the Premier and the Lieutenant Governor. ${ }^{346}$

In 2011, Ontarians elected a minority parliament in which the Liberals retained the plurality, and the assembly sustained Premier McGuinty's government. On 15 October 2012, Premier McGuinty announced his intention to resign as Liberal leader and Premier after the Liberals elected a new leader at a party convention. Kathleen Wynne became Premier of Ontario on 11 February 2013 following a mid-parliamentary transfer of power. Premier Wynne responded to the pressures of leading a minority government by asserting her constitutional right 
to advise, and receive, an early dissolution - notwithstanding Ontario’s fixed-date election law. ${ }^{347}$

On 9 September 2013, Premier Wynne warned the Conservative and New Democratic party leaders that they would face an early dissolution if her minority government loses control of the legislative assembly's agenda. Wynne crafted a deliberately ambiguous threat toward this minority parliament; adopting Prime Minister Harper's tactics of 2008 almost exactly, she pledged to meet with Conservative leader Tim Hudak and New Democratic leader Andrea Horwath, but placed the responsibility of an early election squarely on the opposition parties. The Premier told reporters at Queen's Park:

\begin{abstract}
There's not an indefinite option to continue to wrangle on every single piece of legislation. [...] I want to be clear with people that I'm going to meet with the leaders of the opposition and I'm going to suggest to them that there's some things we can work together on. [...] If there is absolutely no possibility for collaboration, then the legislature will grind to a halt, and the Opposition will have made clear that they want a general election. [...] The practical reality is if the House cannot function, and if we can't see a way forward, then the Opposition will have to explain to people why they think an election is the better option. ${ }^{348}$
\end{abstract}

The CBC reported: "Ontario Premier Kathleen Wynne says her first choice is to work with opposition parties at Queen's Park, but she is willing to call an election if her opponents refuse to let legislative business progress this fall." ${ }^{349}$ Wynne had been well within her rights and responsibilities as Premier to conclude that if her government lost control of the legislative agenda and could no longer pass its legislation, only a direct appeal to the electorate through early elections could break the deadlock and dysfunction of the $40^{\text {th }}$ Legislature.

On 20 September 2013, Premier Wynne reiterated that she could in principle, as First Minister of the Crown, advise the Lieutenant Governor to dissolve the Legislature of Ontario without first having lost a vote of confidence in the assembly. ${ }^{350}$ Wynne pledged not to exercise her capacity to advise an early dissolution if the Progressive Conservatives had ousted their leader at a convention that took place that weekend. Even the website of the Lieutenant Governor of Ontario, acknowledges that the Premier retains the capacity to advise and take responsibility for early dissolution:

Dissolution may be advised in several circumstances outside of the fixed election period, such as $[\mathrm{w}]$ here the Premier is of the opinion that circumstances warrant the calling of a general election in advance of a fixed election date. ${ }^{351}$

On 2 May 2014, Premier Wynne exercised this authority and advised His Honour, David Onley, to dissolve the $40^{\text {th }}$ Legislature because her government faced an imminent loss of confidence, though it had not lost the confidence in the assembly in a formal vote in the chamber. Wynne had hoped that Andrea Horwath, leader of the New Democratic Party, would sustain her Liberal minority government on its upcoming budget, but Horwath had announced on May $1^{\text {st }}$ that the New Democrats would join the Conservatives in voting against the budget implementation bill, saying: "I have lost confidence in Kathleen Wynne and her ability to deliver. Let me be clear, we will be voting against this budget. It is time to go to the people and have them make a decision." 352 Premier Wynne advised the early dissolution because her minority government would certainly have been defeated on the supply bill, and the hung $40^{\text {th }}$ 
Legislature could not possibly have sustained a different government. At her press conference on 2 May, Premier Wynne came up with a novel theory of Responsible Government and argued:

So let's be clear: the decision to go into an election has been made, most immediately by Andrea Horwath, but Tim Hudak and Andrea Horwath have made this decision. We were fully prepared to carry on and have the committees function and so on. We will continue to be open and provide documentation and information. ${ }^{353}$

Interestingly, while the Lieutenant Governor dissolved the $40^{\text {th }}$ Legislature on and in accordance with Premier Wynne's advice on Friday, 2 May 2014, he could not issue the writs of election and proclamation summoning the next parliament pro forma until the following Wednesday, on 7 May 2014, because section 9.1 (3) of the Election Act requires that the writs must be issued on a Wednesday and that the polling day itself must occur on a Thursday. ${ }^{354}$ Since Premier Wynne had already made clear that she retained the authority to advise and receive early dissolution, it is therefore possible that she had been planning on advising the early dissolution on this date but that Andrea Horwath's statement forced her to accelerate her timetable. In the end, Ontarians gave the Liberals a parliamentary majority on 12 June 2014 and thus, if anything, rewarded the Wynne government and the early dissolution.

Due to the early dissolution in 2014, Ontario's and Canada's general elections were no longer scheduled to coincide. Originally, Ontario's next provincial general election was scheduled for October 2018, and the 41st Legislature was therefore scheduled to live for four and one-half years instead of four. In 2014, the Chief Electoral Officer of Ontario released his report of that year's general election and recommended that the legislature change the schedule of fixed-date elections from October to early June, in line with how the election of 2014 in fact occurred. Scheduling general elections in June would prove advantageous because they would coincide with longest hours of daylight of the year and warm weather, thus allowing "candidates and canvassers to interact with the public more easily," decrease the likelihood of overlapping with most religious holidays, prove more convenient for rural communities, hunters, and farmers by falling outside of planting season and hunting seasons for most animals, avoid any overlap between municipal elections scheduled for October 2018 and every fourth October thereafter, and, finally, "provide for a more convenient filing period for parties and candidates.",355

The Wynne government announced as early as June 2015 that it accepted the Chief Electoral Officer's recommendation to shift the scheduled election from October to June, ${ }^{356}$ though Attorney General Yasir Naqvi did not introduce a bill until 19 October 2016. It gained Royal Assent on 8 December 2016. ${ }^{357}$ However, this timeline of events did not prevent the media from talking about the bill as if it had become law even before the government had introduced it; as early as June 2016, several newspapers reported, without qualification, that the next provincial general election had already been scheduled for June $2018 .{ }^{358}$ I pointed out this inaccuracy to the journalists who committed it; Steve Paikin justified his referring to an election scheduled for spring 2018 before the legislature had passed the law changing the timing from October 2018 to June 2018 on the grounds that "the Premier has indicated that she'll move up [the] election to spring 2018 to avoid overlapping with municipal elections that year." ${ }^{359}$ While the Premier can declare that she will advise the Lieutenant-Governor to dissolve the legislature earlier than the scheduled election based on the Crown's executive authority over dissolution, she cannot by her word alone alter the text of statue laws; only the legislature can. Perhaps in this sense, Premier 
Wynne pioneered a new method relative to Newfoundland and Labrador, Manitoba, Saskatchewan, and Prince Edward Island: instead of introducing a bill to delay a provincial general election - and thus lengthen the life of a legislature by one or six months - in the event that it would otherwise overlap with a federal general election, her government tabled a bill to shorten the life of the $41^{\text {st }}$ Parliament of Ontario by four months. The Horgan government adopted the same strategy in British Columbia in 2017.

As with the bill in Newfoundland and Labrador from 2015, this bill in Ontario included more than simply changing the schedule of fixed-date elections, so most of the legislative debates focused on other issues. Furthermore, MPPs themselves, like the journalists who cover them, seemed resigned to shifting the schedule from October 2018 to June 2018 as a fait accompli, and this idea seemed to enjoy broad support from all three parties in the legislature anyway. New Democratic MPP France Gelinas stated matter-of-factly on changing the schedule from October to June during Second Reading, "We already knew that." ${ }^{360}$ Upon Second Reading, Naqvi quoted the aforesaid Chief Electoral Officer's report almost verbatim, noting that a writ in May and June "would mean longer daylight hours [...], which would encourage voters to get to the polls." 361 Other MPPs also parroted the Chief Electoral Officer's report from 2015. However, Conservative MPP Vic Fedeli did point out that switching scheduled provincial general elections to June would come with at least one important consequence: it prevents the Auditor General from tabling her latest report before the election. He wryly added, "I'm sure that it's a coincidence as well." ${ }^{362}$ Echoing her colleague, Conservative MPP Julia Munro likewise criticized the bill for allowing the Wynne government to evade responsibility for the Auditor General's upcoming report and highlighted the hypocrisy of the Liberal Party of Ontario on the issue, since Dalton McGuinty's Liberals in 2003 had denounced Ernie Eves' Conservatives on similar grounds. ${ }^{363}$

But Conservative MPP Tim Arnott offered the only substantive critique of fixed-date election laws themselves in 2016, just as only New Democratic MPP Peter Kormos had done in 2005 when the McGuinty government introduced Ontario's original fixed-date election bill. Arnott acknowledged that "The whole idea of having a fixed term and a fixed-date election well in advance seems to be popular, but I would suggest and submit to the House that it is somewhere inconsistent with the whole idea of parliamentary democracy." 364 He continued:

[I]n parliamentary democratic systems the government is accountable and responsible to the Legislature or to the House of Commons, and, day to day, month to month, year to year it has to govern with the confidence of the House. [...] our greatest power is our decision day to day to express whether or not we have confidence in the government of the day. [...]

The fact is, fixed-term dates are often not adhered to. Certainly, if the government loses the confidence of the House or the Legislature, an election can be triggered, if the Lieutenant Governor agrees that one is necessary. So this whole idea of fixed-term dates, I think, to some degree, is misleading to the people. In this current Parliament, since the election in 2014, I think the government has publicly stated three different election dates. Do we have confidence that this is now the final word on when the election is going to be? I'm not sure how we would, because just in two and a half years, the government has told us three different dates as to when the provincial election is going to be. Again, I would submit that that may change. If there is perhaps a leadership change within the government party - there are a number of scenarios, of course. We don't have to look too far back into history to see where this might, in fact, change yet again. I just want to put that on the record because I think it's important. ${ }^{365}$ 
While the Wynne government had consistently favoured an election in June 2018 as early as June 2015, Arnott correctly points out that the current Canadian model of fixed-date election laws does not prevent early dissolution. In other words, they do not guarantee a minimum lifespan of a legislature of four years, and Premiers - including Premier Wynne herself - have opted for early dissolution, whether in minority or majority legislatures. Sadly, precious few other elected representatives in either the House of Commons or the provincial assemblies have demonstrated as firm a grasp on the principles and practices of Responsible Government as Tim Arnott in 2016 and Peter Kormos in 2005.

Ontario's most recent debates from 2016 also indicated a mixed legacy: on the one hand, the furore and absurd outrage over First Ministers who "break their own laws," as the popular narrative held ten years ago when Prime Minister Harper advised early dissolution, has died out and given way to a new phase of pure apathy. Now, no one really cares when a First Minister "breaks" a fixed-date election law and advises early dissolution, even during a majority legislature, as Premiers Prentice and MacLauchlan did in 2015. But on the other hand, this newfound apathy also equally prevents any serious discussion over repealing these laws. We have moved beyond the earnest, reforming stage to the cynical, new status quo.

\section{$\underline{\text { New Brunswick }}$}

New Brunswick became the fourth province and jurisdiction in Canada to adopt a fixeddate election law in 2007. However, the legislature dealt with two bills, the first of which failed.

Conservative MLA and former Speaker Bev Harrison tabled a bill providing for fixeddate elections along the standard Canadian model while in opposition; his Bill 11, An Act to Amend the Elections Act, ultimately died on the Order Paper. ${ }^{366}$ Harrison spoke to the bill in Second Reading, describing its intention as "get[ting] us in line with the rest of the country" and abolishing the usual "guessing game with the people" on the timing of elections. He also pointed out that British Columbia, Ontario, and Ottawa had considered similar legislation and emphasized inarticulately that the bill would still allow a government to "fall on a confidence motion or on a budget" and permit also "the Lieutenant-Governor the privilege of still calling an election based on any government losing the confidence of the House."367 The Liberal government led by Premier Shawn Graham did not respond substantively to the bill. This experience reinforces the principle that these kinds of bills only succeed as government legislation, and they require the full support of a Ministry willing to take responsibility for their passage.

Strangely, the Graham government tabled equivalent legislation of its own in the same legislative session only three months later, which would seem to violate the general principle in Westminster parliamentarism that two substantively similar bills cannot both be tabled in the same session; a prorogation must first intervene. However, this Bill 75 proposed to amend the Legislative Assembly Act instead of the Elections Act. Government House Leader Stuart Jamieson even acknowledged that "Earlier in this session, [Opposition House Leader Bev Harrison] introduced a bill to achieve a similar goal." He added somewhat tauntingly, "However, this legislation will actually achieve that goal." 368 In those heady days before 2008 and the false narrative that "Harper broke his own law", Jamieson noted that the bill would garner support 
from both sides of the House and that it would promote "better coordination" and provide for the more efficient training of "election workers." 369 He also couched the purpose of the bill in more deliberate - and, ultimately, accurate - language than did Harrison, explaining:

It does not take away any of the traditional powers of the Lieutenant-Governor. If a major circumstance were to arise so that government would need to seek a mandate from the people, or if the people's House became unworkable, we would request to go to the people, and the LieutenantGovernor would exercise his or her discretion. ${ }^{370}$

Jamieson thus did not preclude the possibility that the Premier would advise the Lieutenant Governor to call an election even if the government did not first lose a vote of confidence, and he alluded to the well-established constitutional position that the First Minister can seek dissolution in order to bring a new issue to the people.

Conservative MLA Paul Robichaud mused that the fixed-date elections bill should mandate five-year legislatures instead of scheduling general elections every four years - which is odd, considering that Harrison's bill, which he claimed to support, also called for a four-year legislature. He also said, "If a government decides to go for more than five years, then the Lieutenant-Governor will call the election." ${ }^{371}$ This is not quite right. In reality, if the Premier did not advise a dissolution of the legislature after five years, then it would dissolve automatically by efflux of time in accordance with section 4(1) of the Constitution Act, 1982, without any intervention on the part of the Crown through either the Premier or LieutenantGovernor. ${ }^{372}$ However, Robichaud did correctly state that fixed-date election legislation which schedules general elections every four years would, in effect, reduce the maximum life of a legislature from five years to four years. ${ }^{373}$ Very few elected representatives in Canada seemed to understand this effect of fixed-date election bills during legislative debates. Bill 75 received Royal Assent on 26 June 2007. ${ }^{374}$

New Brunswick incorporated its fixed-date election law into section 2 of the Legislative Assembly Act in 2007. It includes a standard non-derogation clause and set the scheduled general elections on the fourth Monday in September in 2010 at intervals of four years, as those of the other provinces do. Thus far, New Brunswick has held two elections on the fixed schedule, September 2010 and September 2014.

New Brunswick's law contains unique wording: instead of simply stating that a general election shall be held on $\mathrm{x}$ date, or stipulating that the Lieutenant Governor-in-Council shall issue an executive instrument, New Brunswick's statute specifies that the Premier shall advise the Lieutenant Governor. However, these three formulations are all equivalent of one another and nothing in the unique wording of New Brunswick's statute alters the established constitutional positions of the Premier and Lieutenant Governor.

2(1) A Legislative Assembly of the Province shall not be affected by the demise of the Crown.

2(2) The present and every future Legislative Assembly shall continue until dissolved by the Lieutenant Governor.

2(3) Nothing in this section affects the power of the Lieutenant-Governor to prorogue or dissolve the Legislative Assembly at the Lieutenant-Governor's discretion.

2(4) Subject to the power of the Lieutenant-Governor referred to in subsection (3), the Premier shall provide advice to the Lieutenant-Governor that the Legislative Assembly be dissolved and a provincial general election be held on the following dates: 
(a) on Monday, September 27, 2010; and

(b) thereafter, on the fourth Monday in September in the fourth calendar year following the

ordinary polling day for the most recently held provincial general election. ${ }^{375}$

If anything, the wording in New Brunswick's statute simply acknowledges the existing practice more openly and honestly than the "Lieutenant Governor-in-Council" formulation or the "a general election shall be held on $\mathrm{x}$ date" formulation which other provinces have adopted. The legislature cannot last longer than four years, which means that the Premier has to advise dissolution in accordance with the fixed date, unless he had sooner advised dissolution. The fixed-date election laws of most of the other provinces state that "The Lieutenant Governor-inCouncil" shall issue the writs on a given state, by Order-in-Council, or they simply state that the general election shall occur on $\mathrm{x}$ date every four years, which means, by necessity, that the Lieutenant Governor-in-Council must issue an Order-in-Council or proclamation for the dissolution of the legislature and the return of writs - even if the statute does not specifically mention the Lieutenant Governor-in-Council in that section. Furthermore, section 13(1) of New Brunswick's Elections Act does state that "Every election shall be commenced by an order of the Lieutenant Governor-in-Council", and section 13(2) specifies what the Order-in-Council pertaining to the writs of election must do. But this would also conform to the procedure for federal elections. ${ }^{376}$ So both the Legislative Assembly Act and the Elections Act must be taken into account in tandem.

The Royal Gazette of New Brunswick records these same three steps involved in calling an election but, unlike Canada at the federal level, embeds all three within one proclamation, in which the Lieutenant Governor indicates that he has dissolved one legislature, signed an Orderin-Council for the writs of election, and summoned the first session of the next legislature on $\mathrm{x}$ date. While the Royal Gazette does not include the Order-in-Council issued under section 13 of the Elections Act, it does allude to it within this proclamation. ${ }^{377}$ The Executive Council Office of New Brunswick records that Order-in-Council 2014-346 promulgated Premier Alward's advice that the Lieutenant Governor issue the aforesaid proclamation. The Order-in-Council states that "the Premier recommends to the Executive Council" that the Lieutenant Governor issue a proclamation dissolving the current legislature on 21 August 2014, issue the writs of election to be returnable on 3 October, and summon the next Legislative Assembly on 22 October. It concludes that "the Executive Council concur[ed] in said Recommendation", which shows that the Premier initiates the advice and makes the decision on dissolution. ${ }^{378}$

New Brunswick will undertake its third scheduled general election in September 2018.

\section{Manitoba}

As of 2008, Manitoba's fixed-date election law forms part of its Elections Act. Section 49.1(1) of the Act contains the non-derogation clause:

Powers of Lieutenant Governor preserved

49.1(1)

Nothing in this section affects the powers of the Lieutenant Governor, including the power to dissolve the Legislature at the Lieutenant Governor's discretion. ${ }^{379}$ 
Section 49.1(2) fixes the elections on the first Tuesday in October every four years, starting in 2011. As it turned out, however, only the election of October 2011 followed this schedule.

General election on first Tuesday in October

49.1(2) Subject to subsection (1),

(a) a general election must be held on Tuesday, October 4, 2011, unless a general election has

been held between the coming into force of this section and October 3, 2011; and

(b) thereafter, a general election must be held on the first Tuesday in October in the fourth

calendar year after election day for the last general election.

While Manitoba adopted the fixed-date elections law in 2008, the Legislative Assembly first dealt with the issue in 2005. Progressive Conservative MLA Glen Cummings introduced the first fixed-date election bills to the $38^{\text {th }}$ Legislature in 2005; both failed. Cummings explained the rationale of his bill in familiar terms, namely that it would "regularize election dates", allow MLAs and candidates to "plan ahead" for upcoming elections, and prevent the Premier from advising early dissolution on a whim "for political purposes." ${ }^{380}$ Cummings's bill would have enacted the following:

The Lieutenant Governor in Council must under subsection 25(1) of The Elections Act, order that polling at a general election take place on May 8, 2007, and thereafter on the second Tuesday in May in the fourth year following the day of polling for the most recently held general election. ${ }^{381}$

It did not contain a non-derogation clause. As such, this wording would have imposed an unconstitutional fettering of the Crown's authority over dissolution, and the bill would have been ultra vires of section 41(a) of the Constitution Act, 1982.

In Manitoba, a bill that forces the Premier to advise the Lieutenant Governor to dissolve the legislature in the month of May is sheer folly, because torrential floods often submerge southern Manitoba during the spring. Flooding would surely put a damper on any general election campaign and make wading to the polls more difficult. Indeed, Prime Minister Chretien's decision to advise early dissolution in 1997 raised the ire of Manitobans because this inconvenient and early federal general election coincided with "the Flood of the Century."382 Chretien even had the audacity to tour the flooding preparations in Winnipeg before flying back to Ottawa and walking over to Rideau Hall the very next day in order to advise the Governor General to dissolve the $36^{\text {th }}$ Parliament. ${ }^{383}$ The debates on the Doer Government's fixed-date election bill reflect these considerations.

On 12 May 2008, the Doer Government introduced its fixed-dated election bill. Acting Attorney General Steve Ashton explained that it would mandate fixed-date elections every four years, starting on 14 June 2011, along with a provision that would postpone a general election to September in the event of a "major flood." 384 The bill originally said:

Powers of the Lieutenant Governor Preserved

49.1(1) Nothing in this section affects the powers of the Lieutenant Governor, including the power to dissolve the Legislature at the Lieutenant Governor's discretion.

General Election on Second Tuesday in June

49.1(2) Subject to subsection (1) and section 51.1, 
(a) a general election must be held on Tuesday, June 14, 2011, unless a general election has been held between the coming into force of this section and June 13, 2011; and

(b) thereafter, a general election must be held on the second Tuesday in June in the fourth calendar year after election day for the last general election. ${ }^{385}$

The clause "unless a general election has been held between the coming into force of this section and June 13, 2011" raised the ire of the Progressive Conservative and Liberal MLAs on the opposition benches. Liberal MLA Kevin Lamoureux protest that "there's nothing that prevents the Premier (Mr. Doer) from being able to call an election before that June 14 date" but Lamoureux and his colleagues were referring to the aforesaid clause 49.1(2)(a) in particular and not to the general principle underlying all Canadian fixed-date election laws, that they in fact preserve the Crown's authority over dissolution, expressed in the non-derogation clause 49.1(1). ${ }^{386}$ Conservative MLAs Gerald Hawranik and Larry Maguire also objected to the bill for the same reason. ${ }^{387}$ Maguire argued that Premier Doer "could call [the election on] any date in 2010 and still comply with the legislation" and concluded that the bill would leave intact "the political whim of the Premier as to when he really wants to call the date of the next election" though they were referring to the wording of clause 49.1(2)(a) and not to the general principle. ${ }^{388}$ Maguire found this clause redundant in a majority parliament and argued that under a fixed-date election law, the Premier could only advise dissolution in a minority parliament, which presumably means that he would only do so if the government had first lost the confidence of the assembly:

In a minority government situation in our British democracy, minority governments can occur. I would believe that the Premier (Mr. Doer) would have to have the right to go to the LieutenantGovernor and allow for the dissolution of the Legislature so that an election could be called. [...] They're saying that unless a general election has been held between the coming into force of this section and October 3, 2011, then we'll have an election on October 4, $2011 .{ }^{389}$

At the behest of Lamoureux, the Doer government agreed that the Assembly could amend its fixed-date election bill and changed the fixed date to the first Tuesday in October, as the other provinces have chosen. In effect, the Doer Government used its parliamentary majority to extend its own life by four months, as Conservative MLA Derkach pointed out. ${ }^{390}$

Manitoba decided to re-evaluate its legislation four years later in order to prevent the prospect of over-lapping federal and provincial elections. In 2012, the government of New Democratic Premier Greg Selinger introduced a bill to "postpone [the] fixed-date election." The amended law now prevents any future provincial general election from overlapping with a federal general election:

Despite clause (2)(b), if the election period for a general election to be held in October under that clause will, as of January 1 of the year of the election, overlap with the election period for a general election to be held under subsection 56.1(2) or section 56.2 of the Canada Elections Act, the general election must be held instead on the third Tuesday of April in the next calendar year. ${ }^{391}$

In the debates, Conservative MLA Kelvin Geortzen criticized the Selinger government because it might end up having extended its own mandate by extending the life of the Parliament in order to avoid overlapping federal and provincial general elections. ${ }^{392}$ (In fact, it did). His colleague Mavis Taillieu introduced such a bill that would have amended the Selinger government's proposal so that "the general election must be held no later than six months before 
the date of the general to be held under the Canada Elections Act." ${ }^{, 393}$ Taillieu's bill would have shorten the life of the legislature to three and a half years rather than lengthen the life of the legislature to four and half years if the federal and provincial general elections would otherwise have coincided with one another. New Democratic MLA and Government House Leader Jennifer Howard denounced the Conservative amendment, in a bizarre and mendacious comment, on the grounds that it would transfer "the decision for when Manitoba's election should be in the hands of the Prime Minister." 394 Whether the life of the Legislature of Manitoba is shortened by six months or lengthened by six months because of the prospect of overlapping federal and provincial general elections, the decision has something to do with the federal Prime Minister.

Like her counterparts in Saskatchewan and Prince Edward Island, Howard argued that overlapping federal and provincial elections would be untenable, impose numerous logistical problems, and potentially confuse voters. ${ }^{395}$ Howard also corroborated the stories that Premiers Wall and Ghiz and asked Prime Minister Harper to consider changing the federal date (whether by simply "breaking his own law" or by introducing legislation is not known) and stated that "we have written to the Prime Minister and requested that $[\ldots]$ they give some consideration to moving their election date." ${ }^{396}$ Howard acknowledged that if the current $40^{\text {th }}$ Legislature lasted for four and half years, then so too would the $41^{\text {st }}$ Legislature; she also pointed out that four-anda-half-year legislatures have occurred before in Manitoba. ${ }^{397}$ This debate in Manitoba is remarkably similar to the debate in British Columbia in 2011 and shows that when the Opposition considers early elections advantageous, they no longer object to them in principle! Sometimes early elections are justified, and they do not necessarily benefit the Government.

Manitoba held its first scheduled election on 4 October 2011; in the absence of a federal general election, the next provincial general election would have occurred in October 2015. However, Elections Manitoba announced on 5 January 2015 that the next provincial general election will occur instead on 19 April 2016 because as of 1 January 2015, the next federal general election was still scheduled to occur in October 2015. ${ }^{398}$ The wording of Manitoba's fixed-date elections law means that even if Prime Minister Harper had decided to advise an early dissolution so that the federal election occurred before the scheduled date in October 2015, which would have preventing the federal general election and Manitoba's provincial general election from coinciding, Manitoba's provincial general election would still have occurred in April 2016, pursuant to the following provision of the Elections Act:

Postponing fixed date election

49.1(3)

Despite clause (2)(b), if the election period for a general election to be held in October under that clause will, as of January 1 of the year of the election, overlap with the election period for a general election to be held under subsection 56.1(2) or section 56.2 of the Canada Elections Act, the general election must be held instead on the third Tuesday of April in the next calendar year.

On 5 January 2015, Elections Manitoba, rather than the Selinger government per se, announced the postponement of the 41st general election from October 2015 to April 2016:

Manitoba's set date provincial election is now officially moved to April 19, 2016. Under section 49.1(3) of The Elections Amendment Act, the provincial election date moves from October 6, 2015 to the third Tuesday of April 2016 if, by January 1, 2015, the federal election date has not 
been changed. The change to Manitoba's set election date was adopted to eliminate overlap between the timing of provincial and federal elections. ${ }^{399}$

As such, the $40^{\text {th }}$ Legislature lived for four and a half years instead of four, from October 2011 to April 2016. In the 41st general election of April 2016, Manitobans elected a Conservative majority. Conservative Premier Brian Pallister now faces a $41^{\text {st }}$ Legislature that will also live four and one-half years instead of four, from April 2016 to October 2020. Only after the $42^{\text {nd }}$ general election in October 2020 will Manitoba's fixed-date elections re-equilibrate themselves on a true four-year cycle because the $42^{\text {nd }}$ Legislature will be scheduled to live from October 2020 to October 2024.

\section{$\underline{\text { Saskatchewan }}$}

Saskatchewan incorporated its fixed-date election law into its Legislative Assembly and Executive Council Act in 2008. Under the heading "prerogative of the crown not affected," the non-derogation clause of section 8.2 reads:

Nothing in section 8 or 8.1 alters or abridges the power of the Crown to prorogue or dissolve the Legislative Assembly. ${ }^{400}$

Section 8.1 mandates that elections shall occur every four years on the first Monday of November, starting in 2011. The Intergovernmental Affairs and Justice Committee examined the bill and invited Mr. Don Morgan, Attorney General, and Darcy McGovern, Director of Legislative Services in the Ministry of Justice, to appear. McGovern confirmed that Saskatchewan's fixed-date elections law preserves the Crown's authority over dissolution because only a constitutional amendment could eliminate it. McGovern concluded:

it remains the ability of the Crown to dissolve the House at the direction of the Premier. ${ }^{401}$

The Attorney General then acknowledged that the Premier could advise an early dissolution, but that he would probably "pay a horrific price and would have no real reason to go back to the voters" and that an early dissolution would be "problematic from a political perspective." 402 Nevertheless, it would still be legal and constitutional. It is also curious that public officials and scholars over-estimate the political consequences of early dissolution and presume that it is never in the public interest. In reality, the record is mixed, with some early dissolutions benefitting and other resulting in the obliteration of the incumbent government.

After the early federal election of 2011, the Wall government introduced a similar measure to that in Manitoba. If Saskatchewan's provincial general election would overlap with the federal election, then "the general election must be held on the first Monday of April in the calendar year following the calendar year mentioned in subsection (2). ${ }^{, 403}$ Saskatchewan therefore held its next general provincial election on 4 April 2016 - also four and one half years after the previous election - because the federal general election took place as scheduled in October 2015. If the assembly elected in 2016 also lasts its scheduled amount of time, it would then be dissolved in November 2020 and thus also would have lasted four and one-half years. Attorney General Morgan argued that the legislative assembly should pass the law because overlapping federal and provincial elections would "create unacceptable confusion" and would even "undermine the democratic process for each of the federal and provincial campaigns." 404 
When general elections must be held

8.1(1) Unless a general election has been held earlier because of the dissolution of the Legislative Assembly, the first general election after the coming into force of this section must be held on Monday, November 7, 2011.

(2) Subject to subsection (3), general elections following the general election held in accordance with subsection (1) must be held on the first Monday of November in the fourth calendar year after the last general election.

(3) If the writ period for a general election to be held in accordance with subsection (2) overlaps with the writ period for a general election to be held pursuant to subsection 56.1(2) or section 56.2 of the Canada Elections Act, the general election must be held on the first Monday of April in the calendar year following the calendar year mentioned in subsection (2).

(4) In this section, "writ period" means the period commencing on the day that a writ is issued for an election and ending on polling day for that election. ${ }^{405}$

While the Lieutenant Governor gave the bill Royal Assent on 16 May 2012, the local newspapers took little notice of the new law until early 2014. On 26 February 2014, Premier Wall informed the media that his Saskatchewan Party would begin holding riding nominations in March, fully two years in advance of the election. ${ }^{406}$ One columnist also criticized Wall for having reverted "to the old practice of manipulating the election call to gain political advantage. ${ }^{, 407}$ In reality, an election in April 2016 would not necessarily give an unfair advantage to the governing Saskatchewan Party relative to an election in October 2015, and Premier Wall did not invoke the executive authority over dissolution to call for a snap election. However, the $27^{\text {th }}$ Legislature did succeed in prolonging its own life to four and one-half years instead of four, since it lived from October 2011 to April 2016.

While this amendment from 2012 and the delayed general election of 2016 avoided one problem, the altered timeline has created yet another. The $28^{\text {th }}$ Legislature, elected in April 2016, is now also scheduled to last until November 2020, for four and one-half years instead of four. But if the Chief Electoral Officer of Saskatchewan, Michael Boda, has his way, this $28^{\text {th }}$ Legislature could also live for is absolute maximum of the full five years. He issued a report in April 2017 recommending that the province delay its scheduled provincial election from November 2020 to April 2021 so that it does not overlap with municipal elections also scheduled for the fall of 2020. He argued, "Quite simply - it is not administratively tenable that the election periods for any of the three jurisdictional levels overlap." ${ }^{408}$ However, since the current wording of section 8.1(3) of the Legislative Assembly Act only allows that the provincial election be postponed if it would otherwise overlap with a federal general election, the legislature would need to further amend the act in order to delay the provincial election currently scheduled for November 2020 to April 2021. The Chief Electoral Officer acknowledges this fact in his report and states unequivocally:

It is clear, therefore, that the legally set schedule for either the provincial election or municipal election must change - it is administratively untenable for Saskatchewan's 2020 municipal and provincial election periods to be held concurrently. ${ }^{409}$

He recommends that the legislature alter the schedule for the provincial general election because municipalities have no discretion to alter their elections. ${ }^{410}$ However, this rationale could 
just as credibly lend itself to argument why the Premier of Saskatchewan should simply advise the Lieutenant Governor to dissolve the legislature early and hold the provincial earlier than November 2020. But in that case, Premier Scott Moe, who succeeded Brad Wall as Leader of the Saskatchewan Party on 27 January 2018 and as Premier on 2 February $2018,{ }^{411}$ would need to advise a dissolution in the summer or fall or 2018 or the spring of 2019 in order to avoid the federal election scheduled for October 2019 and in order to avoid creating another series of overlapping provincial and municipal elections in 2024. If dissolution occurred in, say April 2020 , then under the current legislation, the provincial and municipal elections would still be scheduled to coincide again in November 2024. Premier Moe's mid-parliamentary appointment has raised the ire of Ryan Meili, the Leader of the New Democratic Party and Her Majesty's Loyal Opposition in the province, who believes that Moe lacks "a mandate" as well as "the trust of the people" of Saskatchewan and should therefore go for an early dissolution. ${ }^{412}$ Moe has rejected the New Democratic Party's clamour for an early election, stating that it would waste $\$ 20$ millions of dollars and arguing that the government should adhere to the scheduled fixeddate election.

The New Democratic Party in British Columbia made the same argument in 2011 after Christie Clark became Premier mid-parliament. In the fall of 2000, Opposition Leader Stockwell Day dared Prime Minister Chretien to call an early election; he did, and the Liberals increased their majority in the resulting snap election. The British Columbian and Saskatchewanian cases show that fixed-date elections cannot hold up to the Mandate Problem, and even ardent proponents of the idea, like Aucoin et al. believe that Premiers appointed mid-parliament should seek their own "mandates" in early elections - which, of course, defeats the entire purpose of fixed-date election laws: certainty and periodicity. This is why Newfoundland and Labrador opted for "The Grimes Law," in which its legislation obliges a Premier appointed in the first or second year of a parliament to advise early dissolution within twelve months. Similarly, Premier Prentice of Alberta and Premier MacLauchlan of Prince Edward Island both chose early dissolution in 2015 after their mid-parliamentary appointments. These mid-parliamentary, intraparliamentary transitions of power happen frequently enough that they are, by definition, not exceptional; they typically happen in a political party's second or third consecutive majority parliament and should therefore be regarded not as aberrant but as part of a normal cycle.

\section{Prince Edward Island}

In 2008, Prince Edward Island added its fixed-date election law into its Election Act; section 4.1(1) contains the standard non-derogation clause:

Nothing in this act affects the powers of the Lieutenant Governor, including the power to dissolve the Legislative Assembly, by proclamation in Her Majesty's name, when the Lieutenant Governor sees fit. ${ }^{413}$

Section 4.1(2) fixes the election to the first Monday in October every four years, starting in 2011.

Like Manitoba and Saskatchewan, Prince Edward Island had to respond to the fallout of the early federal general election of 2011. In December 2013, Liberal Premier Ghiz confirmed in Question Period that his government would introduce legislation in the next sitting modelled on the Manitoban and Saskatchewanian amendments. This law would allow Prince Edward Island 
to hold its next general provincial election in April 2016 so that it does not coincide with the federal election. ${ }^{414}$ Olive Crane, the Conservative Opposition Leader, noted that fixed-date elections were designed to remove the politics from dissolution. ${ }^{415}$ In his reply, Premier Ghiz somewhat surprisingly questioned the very notion of fixed-date elections and implied that he does not support them in principle, asking his colleagues, "[w]ere fixed election dates the best idea?" Ghiz argued that rather than taking the politics out of calling elections, the fixed-date election law has made dissolution and the timing of the election "more political because everyone knows when the election is," and consequently, "every special interest group" lobbies the Premier with the knowledge of when the next election will occur. Ghiz concluded that the next provincial general election would occur in April 2016 - unless the opposition "dared" him to call an election earlier, in which case, he declared: "I reserve my right to do that." 416 Premier Robert Ghiz thus informed the assembly that notwithstanding Prince Edward Island's fixed-date election law, he still retains his capacity to advise and take responsibility for an early dissolution.

Ghiz reasserted his capacity to advise the Lieutenant Governor on prerogative authority in April 2014 during Second Reading, and some of his colleagues - including a Liberal backbencher in his parliamentary caucus - seemed genuinely surprised that the fixed-date election law does not limit this authority. Liberal MLA Richard Brown asked, "The federal government has a fixed election date. You're saying they could break that law?" Premier Ghiz replied:

At any time as Premier, the fixed election date is just in place. You can go to the Lieutenant Governor and say: The Legislature's not working anymore; we need to go to an election. ${ }^{417}$

Ghiz also reiterated his previous example where he, as Premier, might decide to advise an early dissolution if the Opposition dared him to do so, as Stockwell Day unwisely taunted Prime Minister Chretien in 2000:

There could be a new leader who gets elected and says: 'I'm challenging that $[\ldots]$ the current Premier to an election right now.' I have the prerogative to say: 'There's a new leader in place, and they want to go to the polls, we want to go to the polls.' I'll go see the Lieutenant Governor. ${ }^{418}$

Ghiz concluded that he would probably stick to the timetable for the next fixed-date election but that he would "always keep [his] options open." "419 Ghiz thus shows how First Ministers can, in their public relations campaigns, absolve themselves of the responsibility of their offices and foist it upon the leader of the opposition. Premier Wynne did the same in the press conference that she held immediately after advising an early dissolution. Ghiz thus agrees in principle with Prime Minister Harper and Premiers Marois, Wynne, Prentice, and MacLauchlan.

Prince Edward Island's new fixed-date election law now says that if the general federal and provincial general elections would overlap, then "the [provincial] general election shall be held on the fourth Monday in April, in the calendar year following the calendar year." However, unlike in Manitoba's and Saskatchewan's similar legislation, Prince Edward Island's does not stipulate a date, like January $1^{\text {st }}$ in the calendar year of the scheduled election, by when the Premier or Chief Electoral Officer must decide that the provincial general election shall be postponed. The Election Act now reads as follows, as of 2018: 
4.1 Powers of the Lieutenant Governor are not affected

(1) Nothing in this section affects the powers of the Lieutenant Governor, including the power to dissolve the Legislative Assembly, by proclamation in Her Majesty's name, when the Lieutenant Governor sees fit. Elections at four-year intervals

(2) Subject to the powers of the Lieutenant Governor referred to in subsection (1),

(a) a general election shall be held on Monday, October 3, 2011, unless a general election has been held, after the day in which this subsection comes into force and before Monday, October 3, 2011, because of a dissolution of the Legislative Assembly; and

(b) thereafter, general elections shall be held on the first Monday in October in the fourth calendar year following ordinary polling day in the most recent general election.

April general election, circumstances

(3) If the writ period for a general election to be held in accordance with clause (2)(b) overlaps with the writ period for a general election to be held pursuant to subsection 56.1(2) or section 56.2 of the Canada Elections Act, the general election shall be held on the fourth Monday in April, in the calendar year following the calendar year mentioned in clause (2)(b).

Writ period, defined

(4) In subsection (3), "writ period" means, in respect of a general election held under this Act, the period commencing on the date of the writ and ending on the date of the ordinary polling day. ${ }^{421}$

The first provincial general election scheduled under section 4.1(2) of the Election Act occurred in October 2011. The second fixed-date election should therefore have been scheduled originally for October 2015 but then, applying this new provision, should have been postponed to April 2016. The $64^{\text {th }}$ General Assembly should therefore have been scheduled to live for four and one-half years instead of four years, from October 2011 to April 2016. But it did not. This is because Premier MacLauchlan by-passed the whole process.

The Liberals enjoyed a comfortable majority in the $64^{\text {th }}$ General Assembly, elected in 2011, and Robert Ghiz decided to resign as party leader and Premier mid-parliament. The Liberal Party of Prince Edward Island then acclaimed Wade MacLauchlan as leader on 21 February 2015, and the Lieutenant Governor appointed him Premier on 23 February. ${ }^{422}$ However, MacLauchlan was not a sitting MLA. This might explain why he opted for early dissolution rather than serving as an non-MLA Premier for over one year until the next scheduled general election. Under the Heardian viewpoint, here two constitutional conventions came into conflict: the contrived "convention" that First Ministers can only advise early dissolution and by-pass a fixed-date election law if the government has first lost a vote of confidence in the assembly, versus the legitimate, well-established convention that the Premier should be both an Executive Councillor and an elected MLA. A Premier under those circumstances would probably face fewer accusations of democratic illegitimacy by advising early dissolution than by adhering to the scheduled fixed-date election, and so MacLauchlan cut the Gordian Knot and opted for an early dissolution on 6 April 2015; after a writ of 28 days, the general election on 4 May 2015 also yielded a Liberal majority in the $65^{\text {th }}$ General Assembly. ${ }^{423}$

However, MacLauchlan faces a second Fixed-Date Election Problem: the $65^{\text {th }}$ General Assembly is also scheduled to last for longer than four years. The legislation schedules the next provincial election for October 2019, but since that would coincide with the scheduled federal election, the law would postpone the provincial election to April 2020 and thus push the $65^{\text {th }}$ 
Assembly perilously close to its absolute maximum lifespan of five years (4 May 2015 to 4 May 2020), as prescribed in section 4(1) of the Constitution Act, 1982. With a writ of 28 days, MacLauchlan would have to advise the Lieutenant Governor to dissolve the $65^{\text {th }}$ General Assembly on Monday, 23 March 2020 so that the general election can be held on Monday, 20 April 2020. This 65th General Assembly would certainly become the longest-lived elected assembly under a fixed-date election law.

Consequently, I therefore predict that Premier MacLauchlan will advise the LieutenantGovernor to dissolve the current legislature early, perhaps for the fall of 2018 or the spring of 2019 -and thus become the first Premier to advise early dissolution twice. He has already hinted at the prospect of his second early dissolution. Addressing the Liberal Party of Prince Edward Island's Annual General Meeting on 7 April 2018, he told party loyalists, "Of course there will be an election sometime, but there will not be an election in the spring of 2018 " but also insinuated that the election would happen earlier than scheduled under the Election Act, telling delegates, "You might want to consider having a nomination before the end of June."424 Alternatively, the MacLauchlan government could follow Ontario's recent precedent and Conservative Party Leader James Aylward's advice and introduce a bill to switch the schedule of the province's fixed-date elections from the fall to the spring in order to avoid any future potential overlap with a federal election. ${ }^{425}$

\section{$\underline{\text { Alberta }}$}

Alberta passed its fixed-date elections law in 2011 with a slight variation to the Canadian model, which would spare the province from the logistical problem of concurrent federal and provincial elections - but through different means than Manitoba, Saskatchewan, Prince Edward Island, Quebec, and Newfoundland and Labrador later undertook. Section 38.1(1) of its Election Act contains the non-derogation clause:

38.1(1) Nothing in this section affects the powers of the Lieutenant Governor, including the power to dissolve the Legislature, in Her Majesty's name, when the Lieutenant Governor sees fit. ${ }^{426}$

Rather than fixing the election on a precise day of the month, section 38.1(2) builds in a flexible date "within a three-month period beginning on March 1, 2012 and ending on May 31, 2012." Subsequent elections will fall within that range of three months every four years. This represents an important variant on the Canadian method in terms of timing of the election.

Attorney General Verlyn Olsen introduced the fixed-date election bill on 22 November 2011 and acknowledged the constitutional necessity of the non-derogation clause from the outset in the parliamentary debates, unlike his counterparts in the other provinces, who only acknowledged this fact in the more in-depth but less well-covered committee proceedings:

The second amendment clarifies that the Lieutenant Governor's constitutional power to dissolve the Legislature remains intact. Removing this power from the Lieutenant Governor would, we believe, be unconstitutional. ${ }^{427}$

Olsen touted the "made-in-Alberta approach" whereby the law would allow for dissolution within a period of three months, which would allow the Premier to select a date that "does not conflict with days of cultural or religious significance." 428 The other fixed-date election laws 
accommodate for such things by postponing election day by one week. He also acknowledged that a Premier could advise the Lieutenant Governor to dissolve the assembly before the fixed timeframe but that "political consequences [...] would discourage" the Premier from doing so, unless the government had already lost the confidence of the assembly in a formal vote. ${ }^{429}$

Some opposition MLAs attempted to amend the government bill. Harry Chase of the Alberta Liberals introduced an amendment that would have abolished the "made-in-Alberta" method and set the fixed-date elections on the second Tuesday in May starting on 8 May 2012, similar to British Columbia's law. ${ }^{430}$ And New Democrat Rachel Notley introduced an amendment that would have fettered the Crown's authority over dissolution and thus be unconstitutional. $^{431}$ It read:

Prior to March 1, 2012, the Premier shall determine the date of the next election in consultation with the leaders of the opposition parties represented in the Legislative Assembly, and for subsequent general elections, the consultation and determination of the date shall occur no later than 6 months following polling day in the most recent general election. ${ }^{432}$

Through this amendment, Notley sought to limit how the Premier can exercise the discretion to advise and take responsibility for the dissolution of the legislature and therefore necessarily limit how the Lieutenant Governor promulgates that advice. In fact, the legislature cannot drive a wedge between the Governor and First Minister of the Crown without a constitutional amendment. Both amendments failed. Once Rachel Notley became premier in 2015, her enthusiasm for this sort of provision mysteriously evapourated.

Jim Prentice became Premier of Alberta mid-parliament on 15 September $2014 .{ }^{433}$ Under Alberta's fixed-date election law, the next general provincial election is scheduled to take place between March 1 and May 31, 2016. However, Prentice stated, correctly, that he retains the authority to advise the Lieutenant Governor to call an early election. Prentice signalled that he might ask for an early election both in order to seek his own mandate and in order that Albertans can vote on the policies contained in the upcoming budget for 2015 and the government's proposed response to falling revenues and the sharp decline in the price of oil. Prentice told iPolitics:

We do need an election eventually. In the legislation that we have in place, there needs to be an election by the window of March of 2016. The legislation does permit an earlier date. Clearly when that provision was put in place, no one contemplated the financial situation we're in now. $[\ldots]$

I think Albertans need to have a say in that, I think they need to be consulted. [...] It would be irresponsible to not give them the final say in terms of whether they agree with that or not. I've not chosen when an election will happen but I do think a Premier and a government facing these kinds of exigent circumstances needs to have the strong support of Albertans. ${ }^{434}$

In addition, Donald Ethell, the Lieutenant Governor of Alberta, explained the established constitutional position on dissolution: he acknowledged that he would be bound to accept the advice of a Premier whose government commands the confidence of the legislative assembly and that the Premier takes responsibility for the political decision to hold an early election: 
I'm the one who's got to sign off on the Order in Council and I would think that it would be represented by the Premier as having the confidence of the house. If he has the confidence of the House, then I really don't have any argument with that.

[Albertans] just want the government to get on with business so if that means dissolving and going for an election then so be it, but that's a political decision, not mine. ${ }^{435}$

Incidentally, Lieutenant Governor Ethell's comment also reveals that the provincial Lieutenant Governors sign an Order-in-Council in order to dissolve the legislature and go to an election. By definition, an Order-in-Council emanates from cabinet, acting as the Executive Council of the province, which in turn requires a quorum of at least four ministers. So in the provinces, Premiers cannot technically by-pass their cabinets and advise dissolution unilaterally as the federal Prime Minister does through the Instrument of Advice.

Prentice's gamble on early dissolution failed, and he led his Progressive Conservative Party to spectacular defeat and to third-party status. On 5 May 2015, Albertans elected 54 New Democratic MLAs, 21 Wildrose MLAs, and only 10 Progressive Conservative MLAs. The Lieutenant Governor appointed Rachel Notley, leader of the New Democratic Party, Premier on 24 May 2015 as head of a single-party majority government.

\section{Quebec}

In 2012, Quebeckers elected a minority parliament in which the Parti Québécois won the plurality of seats. The $40^{\text {th }}$ National Assembly supported Pauline Marois as Premier of a singleparty minority government. In 2013, Quebec passed a fixed-date election law, which the Parti Québécois had promised in the previous election. ${ }^{436}$ Quebec's new fixed-date elections law had set the first fixed-date election on 26 September 2016 (though that timeline has since changed) and mandates that each subsequent election occur the first Monday in October every four years. ${ }^{437}$

Alone amongst the provinces, Quebec has spread its operative fixed-date election law across two statutes, La loi électorale du Québec and La loi sur l'assemblée national du Québec, which have to be read together. One might say that this makes Quebec distinct.

Section 129 of the Elections Act contains the main provision and schedules elections for the first Monday in October every four years, which puts the date of upcoming elections on 1 October 2018. This provision also includes the non-derogation clause preserving the LieutenantGovernor's authority to dissolve the legislature at any time on and in accordance with the Premier's advice:

129. Lors d'élections générales, la date du scrutin est la même pour toutes les circonscriptions. En application du deuxième alinéa de l'article 6 de la Loi sur l'Assemblée nationale (chapitre A23.1), les élections générales qui suivent l'expiration d'une législature ont lieu le premier lundi du mois d'octobre de la quatrième année civile suivant celle qui comprend le jour de la fin de la législature précédente.

Le présent article n'a pas pour effet de porter atteinte au pouvoir du lieutenant-gouverneur de dissoudre l'Assemblée nationale avant l'expiration d'une législature. ${ }^{438}$ 
This non-derogation clause emphasizes that the legislature dissolves automatically by efflux of time if it reaches its maximum lifespan with the line "the general elections which follow the expiration of the legislature." Crucially, however, this wording takes into account the possibility that some legislatures might not "expire" but would instead be dissolved early, as occurred in Quebec in 2013 when Premier Marois obtained an early dissolution. The law also does not attach any conditions to the authority of the Lieutenant Governor, nor does it attempt to place any restrictions on how the Premier can advise the Lieutenant Governor.

Section 6 of La loi sur l'assemblée national du Québec goes farther than the equivalent provisions of other provincial statutes in explicitly limiting the maximum lifespan of a legislature to between four years and five years, instead of simply five years; as such, it should be regarded as a de facto constitutional amendment under the Section 45 Amending Formula of the Constitution Act, 1982 of section 4(1) of the Constitution Act, 1982. It says that "each legislature expires on 29 August" every four years and repeats the non-derogation clause preserving the Crown's authority over dissolution.

6. Une législature commence dès la réception par le secrétaire général, après des élections générales, de la liste des candidats proclamés élus transmise par le directeur général des élections en vertu de l'article 380 de la Loi électorale (chapitre E-3.3).

Chaque législature expire le 29 août de la quatrième année civile suivant celle qui comprend le jour du scrutin des dernières élections générales.

Toutefois, lorsque la publication prévue au premier alinéa de l'article 129.1 de la Loi électorale a lieu, une législature expire plutôt le 27 février ou, dans le cas d'une année bissextile, le 28 février de la cinquième année civile suivant celle qui comprend le jour du scrutin des dernières élections générales.

Seul le lieutenant-gouverneur peut dissoudre l'Assemblée nationale avant l'expiration d'une législature. ${ }^{439}$

Taking together section 6 of the National Assembly Act and section 129 of the Elections Act means that Quebec's $42^{\text {nd }}$ general election must last a minimum of 34 days, between 29 August and 1 October, inclusive.

Quebec's legislation from 2013 also provides for the possibility of extending the life of a legislature by six months, until the following April, if the scheduled provincial election would otherwise overlap with scheduled municipal or federal elections. But this provision still conforms to section 4(1) of the Constitution Act, 1982 and the absolute maximum lifespan of five years that it prescribes for all legislatures in Canada. Section 129.2 of La loi électorale states:

129.2. Lorsqu'il y a chevauchement de périodes électorales et publication des dates concernées conformément au premier alinéa de l'article 129.1, les élections générales ont lieu, en application du troisième alinéa de l'article 6 de la Loi sur l'Assemblée nationale (chapitre A-23.1), le premier lundi du mois d'avril de la cinquième année civile suivant celle qui comprend le jour de la fin de la législature précédente.

Le directeur général des élections doit alors publier à la Gazette officielle du Québec la date des élections générales visée au premier alinéa. Il doit également faire toute la publicité nécessaire et donner toute l'information pertinente afin de faire connaître cette date au public. ${ }^{440}$ 
In committee, Liberal MNA Christine St-Pierre correctly identified the true nature of the Canadian model of fixed-date elections: the Premier of Quebec does not renounce, through this law, her capacity to advise an early dissolution, and "the Premier can always decide to call an election." ${ }^{441}$ St-Pierre acknowledged that the Premier could advise the Lieutenant Governor to dissolve the assembly before the four-year parliamentary term expires in both a majority parliament or in a minority parliament. ${ }^{442}$ Since this law would "explicitly protect the constitutional power of [...] the Lieutenant Governor to dissolve parliament at his discretion," it also therefore protects the Premier's capacity to advise dissolution at her discretion. " ${ }^{443}$ "The Premier," concluded St-Pierre, "renounces absolutely nothing. He does not renounce his exclusive power" to advise the Lieutenant Governor on dissolution. ${ }^{444}$ St-Pierre also described the clause affirming the Lieutenant Governor's constitutional authority to dissolve the assembly as "a loophole" and recognized that all Canadian jurisdictions have included the same measure. ${ }^{445}$ Guy Tremblay, Professor of Constitutional Law at Laval University, appeared before the committee as an expert witness and argued that a fixed-date election law preserves both "the Lieutenant Governor's power of dissolution" as well as the "recommendations that the Premier can make to the Lieutenant Governor whether to dissolve the assembly." 446 Tremblay stated that the law, at most, creates a "statutory expectation" that the Premier would restrain her constitutional advice, particularly in a majority parliament; while this expectation carries "significant political weight," it nonetheless "is not absolutely binding.",447

Notwithstanding this fixed-date election law, Premier Marois had clearly stated that she still possesses the capacity to advise the Lieutenant Governor to dissolve the assembly under any conditions, whether her government first loses the confidence of the assembly or not. ${ }^{448}$ On 6 February 2014, Marois declared that she "reserves the right" to advise an early dissolution. Marois acknowledged the fixed-date election law and the view that she "must respect her own law," but she argued that so too should the Opposition. She suggested that the law has merely transferred the control of the timing of an election from the Government to the Opposition and that an early dissolution on her initiative would put them on an equal footing: ${ }^{449}$

J'entends les commentaires de ceux qui disent: vous devriez respecter votre loi. Je suis d'accord. Mais ça ne peut pas se jouer seulement d'un côté de la chambre. Ça doit se jouer des deux côtés. Pour l'instant les oppositions nous disent: on aime pas d'avance votre budget, mais on ne sait pas ce qu'il y a dedans. On veut vous renverser sur le budget. Disons qu'on va jouer à armes égales. ${ }^{450}$

On 5 March 2013, Premier Marois exercised her authority to advise and take responsibility for an early dissolution while the National Assembly was in recess, and thus without her minority government having first lost the confidence of the assembly. In so doing, Premier Marois copied and built upon Harper's precedent from 2008. Ultimately, Premier Marois lost her gamble on early dissolution, and Quebeckers gave the Liberals a parliamentary majority in the general provincial election.

Quebec's first provincial general election which follows the schedule contained in La loi électorale du Québec will occur in October 2018. 


\section{Nova Scotia}

As of July 2018, the Legislature of Nova Scotia has yet to pass a fixed-date election law, though four such bills have seen at least First Reading since 2007; the government of the day has introduced none, and none of these private-member's bills has advanced beyond Second Reading.

In 2007, Liberal MLA Stephen McNeil - who is now, eleven years later, Premier and head of a Liberal majority government - introduced a private member's bill in a minority parliament in which the Conservatives formed a single-party minority government. The bill would have established fixed-date elections every second Tuesday in October beginning in 2010, and it included a standard non-derogation clause:

Nothing in this section affects the powers of the Lieutenant Governor, including the power to dissolve the House of Assembly at the discretion of the Lieutenant Governor. ${ }^{451}$

It would also have allowed the Chief Election Officer to recommend delaying the date provincial general election by one week if it came into "conflict with a day of cultural or religious significance or a federal or municipal election. " $" 452 \mathrm{McNeil}$ had thereby anticipated five years before any other fixed-date election law on the statute rolls that provinces would want to delay their general elections if they would otherwise overlap with scheduled federal or municipal elections. This bill died on the Order Paper at First Reading. In 2010, Conservative MLA Murray K. Scott introduced a similar private member's bill in the $61^{\text {st }}$ General Assembly, a majority parliament in which the New Democrats had formed a single-party majority government. It read simply that elections would be held on the first Tuesday in October every four years and included the same non-derogation clause as the bill from the previous General Assembly. ${ }^{453} \mathrm{It}$, too, died on the Order Paper at First Reading.

In 2013, the Leader of the Opposition, Conservative MLA Jamie Baillie, introduced a private member's bill identical to McNeil's legislation from 2007. ${ }^{454}$ By that time, McNeil had become Premier, and Baillie's bill advanced to Second Reading and even garnered the support of the government in principle, but this official sanction did not prevent it from dying on the Order Paper upon prorogation of the $1^{\text {st }}$ session. Liberal Premier Stephen McNeil expressed support in principle for fixed-date elections outside the legislature in the fall of 2013 and the spring of 2014; after all, McNeil had introduced the first fixed-date election bill to Nova Scotia's legislature in 2007. ${ }^{455}$ During the Second Reading debates, Diana Whalen, Minister of Finance in the Liberal government, indicated that the government supports the bill in principle. ${ }^{456}$ However, Whalen also argued that the bill should be amended either along the lines of the new legislation in Saskatchewan, Manitoba, and Prince Edward Island so that if scheduled federal and provincial general elections ever coincided, then the provincial parliament would live on until a dissolution and election the following spring; or, alternatively, that it should be in line with Alberta's fixeddate elections law so that elections could occur within a three-month period instead of on a fixed date. $^{457}$

New Democratic MLA Gordie Gosse noted that the bill contained no provision to deal with a loss of confidence in a minority parliament ${ }^{458}$ and alluded to the possibility of constructive non-confidence. Gosse suggested that the Baillie's bill, as worded, would give the Lieutenant 
Governor more discretion to appoint a new government in a minority parliament if one government had lost a vote of confidence. ${ }^{459}$ Baillie noted, correctly, that the bill preserves the authority of the Lieutenant Governor, who could either dissolve the assembly if the government lost its confidence or appoint a new government from the existing assembly; this is because there must always be a government, and the Crown's first duty is to ensure that there is always a dulyappointed ministry in office. ${ }^{460}$

Baillie later re-introduced his private member's bill in the $2^{\text {nd }}$ session of this 62 General Assembly, but with an interesting modification. ${ }^{461}$ The bill still contains the same non-derogation clause, but "each general election must be held on a Tuesday, as determined by the regulations, in the fourth calendar year following ordinary polling day for the most recent general election" and not on a more specific day like "the second Tuesday of October" as in Baillie's previous bill. This provision would preclude the possibility of a parliament living four and one-half years instead of four years. For example, the $41^{\text {st }}$ Parliament of Canada lasted four and one-half years instead of four, because the hung $40^{\text {th }}$ Parliament was dissolved in March 2011, and the Canada Elections Act stipulates that the next election would occur in October 2015. If the Parliament of Canada had adopted Baillie's bill, then the $41^{\text {st }}$ Parliament would have been dissolved in March 2015 instead.

During the debates at Second Reading, Conservative MLA John Lohr noted that all other provinces but Nova Scotia have adopted a fixed-date election law and lamented that Nova Scotia, the first jurisdiction in what is now the Dominion of Canada to achieve representative government through the establishment of its own legislature in 1758, has now fallen behind the rest of the country. ${ }^{462}$ Curiously, Lohr argued both on the one hand that fixed-date election laws place "restrictions on a government's advantage in calling elections when it is most politically advantageous to do so" "463 and a "regular cycle of planned general elections" and on the other hand that "elections can still be held earlier if the government loses confidence of the Legislature and nothing restricts the royal prerogative of dissolution." ${ }^{, 64}$ Lohr did at least correctly note that the fixed-date election laws leave the Crown's authority over dissolution intact, but his overall statement typifies the dissonance and ambivalence that most parliamentarians have demonstrated on this subject. New Democratic MLA and House Leader Maureen Macdonald questioned the necessity of a fixed-date election law and suggested that it does not remedy any real problem in Nova Scotia and that there is no "problem in the Province of Nova Scotia of majority governments calling elections too frequently or too infrequently." ${ }^{.45}$ MacDonald also characterized the fixed-date election laws as a project of the right-wing in Canada and noted that the Reform Party, Canadian Alliance, and Conservative Party had promoted them. ${ }^{466}$ While it is true that the right-wing promoted fixed-date election laws in the 1990s, and that Premier Gordon Campbell's government in British Columbia introduced the first such legislation in 2001; however, Liberal and New Democratic governments introduced similar legislation in Ontario and Manitoba.

In his report on the provincial general election of 2013, the Chief Electoral Officer of Nova Scotia recommended that the legislature adopt fixed-date elections. ${ }^{467}$ Curiously, he describes "two models" of fixed-date elections in Canada: one that depends upon setting the election on a fixed date like the second Tuesday in October, as Canada at the federal level and all the provinces except Alberta have adopted, and Alberta's method of setting the date of the next 
election with a 90-day timeframe between March 1 and May 31. ${ }^{468}$ In reality, all federal and provincial fixed-date election laws rely on the same "model" of preserving the Crown's authority over dissolution in order to avoid amending the Constitution of Canada. But by the Chief Electoral Officer's logic, Baillie's new bill would allow Nova Scotia to pioneer a third "model" of fixed-date elections, whereby each parliament would live for only four years instead of fourand-one-half years because his new bill does not specify the month in which the election would occur.

On 9 April 2015, Liberal Premier Stephen McNeil came out against fixed-date election laws, saying:

\begin{abstract}
What we are seeing is the fixed dates haven't been working, so when we amended the legislation we didn't put one in. [...] Legislation across the country hasn't resulted in fixed election dates, that's the issue. We're not in the business of creating legislation that people don't adhere to or wouldn't be adhered to in this province. ${ }^{469}$
\end{abstract}

McNeil is correct; the experience in the other nine provinces shows that fixed-date elections are more bother than they are worth. Not coincidentally, he concluded that these laws do nothing soon after Premiers Prentice and MacLauchlan advised snap elections when their parties held legislative majorities.

\title{
X: Territorial Fixed-Date Election Laws in Canada, 2007-2018
}

\section{Introduction on Consensus Government}

The Northwest Territories and Nunavut have also adopted territorial fixed-date election legislation, though Yukon, like Nova Scotia, has thus far decided not to adopt a fixed schedule. The territorial fixed-date election laws take a slightly different form; they include non-derogation clauses, but instead of preserving the offices of the territorial Commissioners, they instead preserve dissolution relative to the federal Northwest Territories Act and Nunavut Act. Unlike the provinces, Canada's territories do not enjoy constitutional entrenchment and remain instead subject to the general authority of the Parliament of Canada, which provides for devolved territorial executives and legislatures through the Yukon Act, Northwest Territories Act, and Nunavut Act. And, crucially, the offices of the territorial commissioners do not enjoy constitutional entrenchment under section 41(a) of the Constitution Act, 1982 alongside the offices of the Queen of Canada, the Governor General of Canada, and the Lieutenant Governors of the ten provinces.

Interestingly, many features of the constitutional position Ottawa and the territories mirror the established constitutional position between London and the British North American colonies from the 1840s to 1931. Until 1931, the Governor General of Canada served as an officer of the British government accountable to and appointed by the Sovereign on the advice of the Colonial Secretary. ${ }^{470}$ The Queen issued letters patent to the Governor General on the advice of the Colonial Secretary or the Imperial cabinet as a whole, and the Colonial Secretary issued his own set of letters and instructions to the Governor General upon his appointment. ${ }^{471}$ For instance, Colonial Secretary Earl Grey instructed Governor General Lord Elgin to implement Responsible Government in the Province of Canada in a letter dated 1847. Similarly, the 
Governor-in-Council appoints the territorial Commissioners as federal officers in accordance with the federal statutes governing the constitutional status of and level of self-government within the territories, the Yukon Act, the Northwest Territories Act, and the Nunavut Act. ${ }^{472}$

The territorial Commissioners, in turn, report directly to the Minister of Indigenous and Northern Affairs, who issues them a set of letters and instructions and a copy of Commissioners of the Territories, a briefing book prepared by the Department of Indigenous and Northern Affairs, upon their appointment. ${ }^{473}$ For example, Minister John Duncan sent the George Tuccaro, as the newly appointed Commissioner of the Northwest Territories, letters and instructions on 6 October 2010 that "provide guidance on the role of the Commissioner" relative to the Legislative Assembly, Executive Council, and Premier of the Northwest Territories "in accordance with the principles of responsible government and executive accountability." 474 The Northern Governance and Partnerships Directorate, within the Northern Governance Branch of the Department of Indigenous and Northern Affairs, supports the Minister in dealing with the territorial Commissioners. ${ }^{475}$

Yukon attained territorial self-government with province-like authority in 1978, and Yukon's first fully elected legislative assembly opted to organize itself through political parties and decided to adopt the same conventions and practices of Responsible Government present in the provinces and Ottawa. The Northwest Territories finally reacquired self-government with province-like authority in 1975. Unlike Yukon, however, the Northwest Territories' first elected legislative assembly allowed a different system of government to take root; Nunavut later decided to adopt the same system upon the election of its $1^{\text {st }}$ Legislature in 1999.

The Northwest Territories and Nunavut have pioneered a unique system called "Consensus Government," which grew out of a form of consociationalism and differs from Responsible Government in several key respects. ${ }^{476}$ First, Consensus Government rejects political parties; instead, all MLAs represent their districts as independents, either as part of the political executive or as "Regular Members" not part of the cabinet. Second, Consensus Government does not rely mainly on constitutional conventions; instead, the legislatures of Northwest Territories and Nunavut have codified most of the key elements of this novel system of government within their Executive Council and Legislative Assembly Acts and have thereby significantly limited the authority of the political executive relative to that of the legislative assembly. Third, like Continental European parliamentary systems, Consensus Government relies on confirmation voting and constructive non-confidence, but unlike any other parliamentary system, it also recognizes only individual ministerial responsibility and rejects collective ministerial responsibility and cabinet solidarity.

In practical terms, this means that the Legislative Assembly can only withdraw confidence from individual Executive Councillors, and it means that, unlike under Responsible Government, the tenure of the Premier does not determine the tenure of the ministry as a whole. Instead, the assembly would have to mimic collective ministerial responsibility by tabling a motion revoking "the appointments of the Premier and all Members of the Executive Council", as the Legislative Assembly of the Northwest Territories did in February 2009. ${ }^{477}$ (That motion was defeated). For example, on 14 June 2018, the Legislative Assembly of Nunavut took the unprecedented step of ousting Paul Quassa as Premier and replacing him with Joe Saviktaaq, but 
this did not entail getting rid of the entire Executive Council. ${ }^{478}$ In contrast, motions of nonconfidence in the House of Commons and provincial legislative assemblies take the form, "That his House has lost confidence in the government," and the entire Ministry stands or falls as one. ${ }^{479}$

Sections 61 to 69 of the Executive Council and Legislative Assembly Act of the Northwest Territories codify the principles of Consensus Government. Section 61 states that the Commissioner appoints the Premier and other Executive Councillors "on the recommendation of the Legislative Assembly," and section 64(1) adds that "If a vacancy occurs in the office of Premier by death, resignation or otherwise, the Legislative Assembly shall choose another of its members to be Premier." Unlike in Yukon, the provinces, and Ottawa, the Premier can only build a cabinet and assign portfolios from amongst these Executive Councillors whom the Commissioner appointed on the advice of the Assembly. Under section 66(1), "The Commissioner, on the advice of the Premier, may appoint under the Seal, from among the members of the Executive Council, the Ministers of the executive government."

While the Premier can advise the Commissioner to "revoke an appointment of a member of the Executive Council as a Minister," only the Legislative Assembly can remove an Executive Councillor. Confirmation voting facilitates the transfer of power between Premiers and Executive Councillors; under section 64(2), "The person who holds the office of Premier at the time of a dissolution of the Legislative Assembly continues to hold the office of Premier until the next Premier is chosen at the first sitting of the next Legislative Assembly," and section 69 likewise provides for the continuity of Executive Councillors between general elections. Furthermore, section 3.1(2) of the act mandates that "The Commissioner shall convene the first session of a Legislative Assembly within 45 days after the day fixed for the return of the writs". Nunavut's Executive Council and Legislative Assembly Act contains substantially the same provisions because the new territory decided to adopt Consensus Government upon its creation in 1999, and because Northwest Territories law formed the basis of Nunavut law. ${ }^{480}$

\section{Northwest Territories}

Section 39(5) of the Northwest Territories'Elections and Plebiscites Act contains the territory's fixed-date elections law and schedules general elections for the first Monday in every fourth October, starting in 2007; subsequent scheduled elections occurred in 2011 and 2015:

39 (5) Subject to the power of the Governor in Council under subsection 9(3) of the Northwest Territories Act (Canada) to dissolve the Legislative Assembly at any time after consultation, and to cause a new Legislative Assembly to be elected, polling day for a general election must be the first Monday in October in the fourth calendar year following polling day for the last general election. ${ }^{481}$

While the provincial fixed-date election provisions refer to the general authority of the Lieutenant Governors to dissolve the legislature, which flows from the Constitution of Canada, the Northwest Territories' equivalent statute refers to section 9(3) of the federal Northwest Territories Act, the federal statute which created the entire state apparatus and all branches of government of the Northwest Territories: 
9 (3) Every Council shall continue for four years from the date of the return of the writs for the general election and no longer, but the Governor in Council may at any time, after consultation with the Council where the Governor in Council deems consultation to be practicable or, otherwise, after consultation with each of the members of the Council with whom consultation can then be effected, dissolve the Council and cause a new Council to be elected. ${ }^{482}$

The large omnibus bill which combined the Elections Act and the Plebiscite Act into one statute underwent very little substantive debate in October 2006; the provision for fixed-date elections, even less so. Only two MLAs even mentioned the fixed-date election provision, and both supported it in bland generalities and platitudes. David Ramsay said, "Madam Chair, the new act also established the first Monday in October every four years as the permanent general election day for the Northwest Territories, commencing with Monday, October 1, 2007." ${ }^{483}$ Sandy Lee added that the bill would "set the time for the election and it's now going to be known with certainty" and that "In the past, election days were not set." 484

\section{$\underline{\text { Nunavut }}$}

Section 17 of the federal Nunavut Act sets the maximum lifespan of Nunavut's legislatures at five years, as opposed to the four years that the Parliament of Canada allows for that of the Northwest Territories.

17. No Assembly shall continue for longer than five years from the date of the return of the writs for the general election, but the Commissioner may at any time, after consultation with the Executive Council, dissolve the Assembly. ${ }^{485}$

Section 36(3.1) of the Nunavut Elections Act effectively shortens the maximum lifespan of its territorial legislature from five years to four and schedules general elections for the last Monday of every fourth October:

Fixed election day

(3.1) Subject to section 17 of the Nunavut Act (Canada), the election day for a general election must be the last Monday in October in the fourth calendar year following the election day for the most recent general election. ${ }^{486}$

The first scheduled election occurred in October 2017, and the next will occur in October 2021.

The Speaker, George Qulaut - rather than Keith Peterson, the Minister of Finance who introduced the bill, which shows how Consensus Government differs from Responsible Government - spoke to the substance of the bill introduced in 2014. Speaker Qulaut made the standard arguments about openness and accountability and noted that Nunavut would conform to the general Canadian trend:

Mr. Chairman, as caucus indicated in its announcement, this measure will provide the government with a transparent, predictable, and manageable timeframe in which to achieve its goals.

I would also note that most provinces and territories have also passed legislation in recent years to provide for fixed election dates. ${ }^{487}$

He also noted that Nunavut's fixed-date election law would include the equivalent of a non-derogation clause that preserves the authority of the Governor-in-Council to dissolve the legislature early: 
Mr. Chairman, it is important to note that the passage of this legislation would not restrict the exercise of the royal prerogative of dissolution and does not impact section 17 of the federal Nunavut Act. This prerogative could need to be exercised in the event of a catastrophic occurrence. Similar provisions exist in other jurisdictions' legislation. ${ }^{488}$

The bill passed with no substantive debate on its merits.

\section{Analysis of Fixed-Date Election Laws Under Consensus Government}

In Ottawa and the provinces, the Governor can dissolve the legislature early at any time on the advice of the First Minister. In other words, the Crown can very easily dissolve the legislature well before it would dissolve by efflux of time. However, this is not the case in the territories. The territorial Premier would have to submit a request to the Prime Minister that the Governor-in-Council (i.e., the federal Cabinet through an Order-in-Council) bring about the early dissolution of the Legislature. This rarely happens, not least because the mechanics of Consensus Government would make such a request from a territorial Premier highly impracticable and unlikely. By default, the territorial legislatures dissolve by efflux of time in accordance with their federal enabling statutes and, secondarily, under relevant territorial legislation.

Only the federal and provincial orders of government enjoy constitutional entrenchment, which, in turn, means that section 41(a) of the Constitution Act, 1982 applies only to the offices of the Queen, Governor General, and the Lieutenant Governors - but not to the offices of the territorial Commissioners. As such, the Crown's executive authority over dissolution only benefits from constitutional entrenchment in Ottawa and the provinces, while the constitutional positions of the territorial Commissioners and Premiers remain subject to the jurisdiction of the devolved territorial assemblies. In other words, the devolved territorial legislatures therefore possess significant latitude to regulate the exercise of all executive authorities and legislate as far as their federal enabling statutes allow; unlike the Parliament of Canada and provincial legislatures, the territorial legislature very much can drive a wedge between the Commissioner on the one hand and the Premier and Executive Council on the other. Theoretically, the Parliament of Canada and territorial assemblies could abolish any authority vested in the territorial executive.

In fact, the assemblies of Northwest Territories and Nunavut have taken advantage of their authority to drive a wedge between the Commissioner and Premier and have dispensed with Responsible Government, as practised in Ottawa, the provinces, and Yukon, altogether. Consensus Government - and the restrictions on executive authority that make it possible - can only exist in the territories precisely because section 41(a) of the Constitution Act, 1982 does not entrench the offices of the offices of the territorial Commissioners in the Constitution of Canada alongside the offices of the Queen, Governor General, and Lieutenant Governors. Even proponents of Consensus Government acknowledge that it is not scalable to the federal House of Commons and provincial legislative assemblies in practical terms; more importantly, Consensus Government would also be unconstitutional and ultra vires of section 9 of the Constitution Act, 1867 and section 41(a) of the Constitution Act, 1982 outside of the territories because of how it derogates from executive authority. 
While the Northwest Territories' and Nunavut's fixed-date election laws also typify what Thelen and Mahoney call Layering, the non-entrenchment of the territories in the Constitution of Canada gives these territorial legislatures, in conjuncture with the Parliament of Canada, wide latitude for political and institutional experimentation. Consensus Government itself developed organically in Northwest Territories and, by extension, in its offshoot territory of Nunavut, so it could only be regarded as form of Conversion relative to the Responsible Government practised elsewhere in Canada but not within those territories themselves.

Finally, Consensus Government in the Northwest Territories and Nunavut demonstrates that the constitutional entrenchment of executive authority within the federal and provincial orders of government limits the competency of Parliament and the legislatures to derogate from the Crown's powers and authorities, like over dissolution. The territories remain free to drive a wedge between the Commissioner and the Premier (and, in turn, between the Premier and the Ministry) because of their unique legal-constitutional arrangements as creatures of the federal parliament and government, but only two of the three have opted to do so.

\section{XI: There and Back Again: A Tale of Dissolution from 1640 to 2011}

\section{The Waxing and Waning Prerogative of Dissolution in England and the United Kingdom}

In England and the United Kingdom, the source of the Crown's authority over dissolution has oscillated between prerogative and statute on several occasions since 1640. From 1640 to 2011, various English and British parliaments have eliminated, restored, and limited the Crown's prerogatives over summoning and dissolving parliament in order to regulate both the maximum life of a parliament and the maximum number of years between each parliament. In terms of the Thelen-Mahoney Model, fixed-term parliaments in England and the United Kingdom oscillated between Displacement and Layering, and a concurrent institutional change occurred in parallel where parliamentarism shifted over time, due to the Drift which brought about the gradual emergence of Cabinet Government.

Figure 3: The Dissolution Oscillation

\begin{tabular}{|c|c|}
\hline Statutes Regulating Dissolution & Type of Institutional Change At Work \\
\hline The first Triennial Act, 1640 & Layering \\
\hline $\begin{array}{l}\text { The Act Against Dissolving the Long Parliament Without } \\
\text { Its Own Consent, } 1641\end{array}$ & Displacement \\
\hline The second Triennial Act, 1664 & $\begin{array}{l}\text { Displacement (restoration to pre- } 1640 \text { authority) } \\
\text { and Conversion in favour of the King }\end{array}$ \\
\hline The third Triennial Act, 1694 & $\begin{array}{l}\text { Layering preceded by Drift in favour of the } \\
\text { Commons }\end{array}$ \\
\hline The Septennial Act, 1715 & $\begin{array}{l}\text { Layering followed by Drift toward modern } \\
\text { Cabinet Government }\end{array}$ \\
\hline The Parliament Act, 1911 & Layering \\
\hline The Fixed-Term Parliaments Act, 2011 & $\begin{array}{l}\text { Displacement to Continental European-style } \\
\text { parliamentarism }\end{array}$ \\
\hline $\begin{array}{l}\text { Potential Future Repeal of the } \\
\text { Fixed-Term Parliaments Act, } 2011\end{array}$ & $\begin{array}{l}\text { Displacement } \\
\text { (Restoration to pre-2010 System) }\end{array}$ \\
\hline
\end{tabular}


The Tudor and Stuart monarchs summoned parliaments not merely to request tax revenue, but also to enact policies. ${ }^{489}$ Since 2008 in Canada, prorogation has become synonymous with "cutting short" and "shutting down", but in the Early Modern Era, prorogation remained true to its etymology: "prolongation", or "continuation." Russell notes that Prime Minister Harper prorogued the "pesky" $40^{\text {th }}$ Parliament of Canada twice, in 2008 and again in 2009, and asserts - incorrectly - that Henry VIII also prorogued pesky parliaments. ${ }^{490}$ In fact, the Tudors and Stuarts dissolved pesky parliaments and prorogued - i.e., prolonged - favourable parliaments, rather than risk dissolving them and summoning new, potentially less pliable parliaments. ${ }^{491}$ Charles I dissolved several parliaments which expressed hostility to the Jacobean philosophy on the Divine Right of Kings. In contrast, Henry VIII used prorogation to extend the life of the Reformation Parliament to seven years; it sat through seven sessions between 1529 and 1536 and passed a variety of statutes that broke with the Holy See and established England as an independent Protestant kingdom. ${ }^{492}$ And Charles II prolonged the life of the Cavalier Parliament and its Royalist majority from 1661 to 1679 by proroguing it 17 times. The Sovereign thus determined at his own discretion both the duration of each individual parliament through prorogation and the number of years between parliaments through summoning and dissolution.

During the Royal Supremacy (1534-1688), parliamentary sovereignty provided a primitive and nascent form of political deterrent. While the Sovereign could undoubtedly exercise his prerogative authority at his discretion and dissolve parliament at will, a good King would do so with aplomb, tact, and political sagacity in order to avoid antagonizing the Lords and Commons and alienating his subjects.

Charles I ascended to the throne in 1625, he dissolved three pesky parliaments - in 1625 , 1626, and 1628 - in quick succession. He then reigned from 1628 to 1640 without summoning any parliament at all, in what Whigs call the Eleven Years' Tyranny, and raised various types of limited revenues under prerogative authority, all while avoiding costly wars abroad. ${ }^{493}$ Eventually, Charles I had to summon a new parliament, but he fell back on his earlier ways and he dissolved the so-called Short Parliament of 1640 after it had sat for only three weeks. ${ }^{494}$ However, Charles had to summon a second parliament in the same year in order to raise supply to finance his campaign in the Bishops' War in Scotland. ${ }^{495}$ This Long Parliament sat from 1640 through the English Civil War and the Cromwellian Protectorate until 1660, when it allowed for the Restoration and dissolved itself. In 1640, the Long Parliament took advantage of the King's weak position and imposed a law that limited the King's prerogatives of summoning, proroguing, and dissolving parliament.

Parliament expressed its dissatisfaction in Charles I through the formal long title of the Triennial Act, 1640: "An Act for the preventing of inconveniencies happening by the long intermission of parliaments." In its preamble, Parliament admonished Charles I's eleven years of personal rule:

\footnotetext{
Whereas by the Laws and Statutes of this Realm, the Parliament ought to be holden at least once year for the redress of grievances, but the appointment of the time and place for the holding thereof hath always belonged to his Majesty and his Royal Progenitors. And whereas, it is by experience found that the not holding of Parliaments accordingly hath produced sundry and great mischiefs and inconveniences to the King's Majesty, the Church, and the Commonwealth. ${ }^{496}$
} 
Section 6 of the first Triennial Act, 1640 stipulated that within the first fifty days of the life of a parliament, only an act of parliament itself could prorogue the session or dissolve the parliament and that only the House of Commons and the House of Lords could adjourn themselves. ${ }^{497}$ However, the King's prerogatives remained intact after that initial fifty days. Section 2 of the act mandated that the King must summon a parliament at least once every three years; if he did not, the Lord Chancellor would instead issue the writs under the Great Seal. However, the Parliament would not necessarily sit continuously for a duration of three years; Parliament could, for instance, sit for one year and remain dissolved for two years. On the third year, the King, or the Lord Chancellor, would summon a new Parliament. The first Triennial Act also affirmed parliamentary privilege by asserting the right of the Lords and Commons to elect their own speakers and to adjourn themselves. Overall, the Triennial Act, 1640 regulated and limited the King's prerogatives to summon, prorogue, and dissolve parliament - but it did not put them into abeyance. The balance of power under this act might have proven stable over the long term, but the Long Parliament soon adopted a far more radical measure. And the Cavalier Parliament implemented a reactionary measure upon the Restoration.

In 1641, the Long Parliament extracted further concessions from Charles I and temporarily put into abeyance the prerogative powers of adjournment, prorogation, and dissolution through the Act Against Dissolving the Long Parliament Without Its Consent. The preamble of the act noted Charles I's tendency to dissolve pesky parliaments hastily, his contempt for the ancient principle of grievance before supply, and that the King needed revenue in order to prosecute the Bishops' War in Scotland. ${ }^{498}$ The act temporarily put key prerogative powers into abeyance:

this present Parliament now assembled shall not be dissolved unless by Act of Parliament to be passed for that purpose; nor shall be, at any time or times, during the continuance thereof, prorogued or adjourned, unless it be by Act of Parliament to be likewise passed for that purpose. ${ }^{499}$

This act built upon the principles contained in the Triennial Act, 1640 and declared that only an act of parliament could adjourn, prorogue, or dissolve that particular parliament. This statute put the prerogative authority of the Crown into abeyance, but only for the life of that indeterminate parliament. Once the Long Parliament dissolved itself, the Crown's prerogative authority of summoning, prorogation, and dissolution re-emerged under the terms of the Triennial Act, 1640. Blackstone argues that the Act Against Dissolving the Long Parliament Without Its Consent, 1641 exposed the necessity of the Crown's authority of dissolution:

If nothing had a right to prorogue or dissolve a parliament but itself, it might happen to become perpetual. And this would be extremely dangerous, if at any time it should attempt to encroach upon the executive power: as was fatally experienced by the unfortunate king Charles the first; who, having unadvisedly passed an act to continue the parliament then in being till such time as it should please to dissolve itself, at last fell a victim to that inordinate power, which he himself had consented to give them. It is therefore extremely necessary that the crown should be empowered to regulate the duration of these assemblies $[\ldots] .{ }^{500}$

In effect, the Long Parliament Act of 1641 made prorogation and dissolution matters of collective parliamentary privilege on par with the well-established collective parliamentary privileges that a legislative body can govern its internal affairs and adjourn itself. This arrangement collapses into anarchy because it works against the nature and structure of Parliament (the Crown-in-Parliament) itself, which consists of King, Lords, and Commons. In 
contrast, a statute law like the Fixed-Term Parliaments Act, 2011 can work, both under Blackstone's definition and with respect to the Crown-in-Parliament, because statute laws remain outside the authority of the House of Commons alone to amend and represent the three components of the tripartite Crown-in-Parliament working in concert with one another. A statute law thus replaces the Sovereign's prerogative and acts as the outside authority by which Parliament is dissolved.

The first Triennial Act, 1640 falls under Layering because it placed some conditions upon the Sovereign's authority over dissolution while keeping the basic authority itself intact. But the Act Against Dissolving the Long Parliament Without Its Own Consent, 1641 falls under Displacement because it put the King's prerogative authority over dissolution into abeyance, at least for the duration of that one parliament. Oliver Cromwell's regicide of Charles I in 1649 stands as the ultimate Displacement in English history - but even that Displacement did not last and usher in permanent change. Instead, the Rump of the Long Parliament invited Charles II to return to England and reign as King, and the Restoration Parliament, also known as the Cavalier Parliament, of Charles II passed the second Triennial Act, 1664.

The Long Parliament survived the tumult of the English Civil Wars of the 1640s, the execution of Charles I in 1649, the Cromwellian Interregnum of the 1650s, and finally, the Restoration of the Crown in 1660. Charles II summoned his first Parliament in 1661 but did not dissolve it until 1679. This capricious Cavalier Parliament lasted almost as long as the Long Parliament that it succeeded, notwithstanding the provisions of the second Triennial Act, 1664. The Long Parliament's Act Against Dissolving the Long Parliament naturally expired upon its dissolution, but the first Triennial Act of 1640 - and its limitation on the prerogative authority remained on the statute rolls until the Royalist Cavalier Parliament repealed it in 1664, just before this parliament would have been dissolved by efflux of time under the terms of that act. The Cavalier Parliament declared that the first Triennial Act, 1640 had "derogate[d from] His Majesty's just Rights and Prerogatives inherent to Imperial Crown of this Realm" and so dutifully repealed it. ${ }^{501}$ In its stead, the Cavalier Parliament extended its own life by restoring the Crown's full prerogative and discretionary authority through the Triennial Act, 1664. This Displacement restored the old system pre-1640 and removed all the previous Layering. While this statute contained the germ of Conversion toward regular parliaments, Charles II did precisely the opposite: he took advantage of the ambiguity of the Triennial Act, 1664, which neither expressly imposed a maximum lifespan of three years on a parliament nor required fresh elections every three years, and simply kept the Restoration Parliament alive for almost two decades.

In the Triennial Act, 1664, the Cavalier Parliament "beseeched" Charles II to summon a new parliament at least once every three years "because by the ancient Laws and Statutes of this Realm made in the Reign of Edward III, Parliaments are to be held very often." In this case, the same Parliament was held often. Unlike the first Triennial Act, however, Parliament but did not specify that the King must issue the writs of election every three years, nor did it delegate that authority to the Lord Chancellor if the King failed to do so. ${ }^{502}$ Charles II ignored the non-binding sentiment of the second Triennial Act, 1664 that "beseeched" him to abide by the medieval, preTudor convention of summoning new parliaments regularly. Charles I simply dissolved pesky parliaments that questioned royal authority and then refused to call a new parliament during the 
Eleven Years' Tyranny. But his son, Charles II, proved a more cunning and adept political operator. Thelen and Mahoney note that ambiguity of interpretation and lack of enforcement allow cunning political actors "to implement existing rules in new ways" and promote Conversion. ${ }^{503}$ Charles II exploited the uncertainty and powerlessness of the Triennial Act, 1664 to his advantage; he perverted the restored old system into a new despotism, keeping the Restoration Parliament and its favourable Anglican majority alive for 18 years by proroguing it 17 times.

This second iteration of the Triennial Act bears some resemblance to the Canadian model of fixed-date elections, because both styles of legislation preserve the Crown's authority over dissolution, contain no enforcement mechanism, and rely only upon the arbitrary judgement of the Crown. By repealing the Triennial Act, 1640, which limited the prerogative of summoning, prorogation, and dissolution, the Cavalier Parliament allowed the King's prerogative authority to return to full force with no restrictions. And like the current Canadian fixed-date election laws, the Triennial Act, 1664 certainly did not create a new constitutional convention. It was merely a failure.

The Glorious Revolution of November 1688, through which the Convention Parliament de facto deposed the Catholic James II of the House of Stuart and invited the Calvinist William of Orange and Mary Stuart, a Protestant daughter to James II, to take the English throne, exemplifies Displacement. From the point of view of its Protestant Whig proponents, the Glorious Revolution and the de facto abdication of James II, who had fled to France rather than fight William of Orange in open battle, exemplifies a peaceful Displacement in order to restore the ancient English liberties which the Stuart Kings had usurped. Their Catholic and Tory opponents would probably agree that deposing James II amounted to Displacement, though they took issue with the new constitutional settlement and saw it as usurpation rather than restoration.

The Triennial Act, 1640 only ensured that the interval between parliaments would last no more than three years, and it only guaranteed that a parliament could last for 50 days before the King could dissolve it. It did not ensure that the parliament itself would last three years, though this doctrine later emerged as a corollary to the Triennial Acts. The Triennial Act, 1664 in practice enforced neither the maximum life of a parliament nor the maximum number of years between parliaments. Parliament finally dealt with both issues through the Act for the frequent meeting and calling of parliaments, also known as the Triennial Act, 1694, the third statute to bear that name. This statute set the maximum life of a parliament at three years, at which time the King would dissolve it; crucially, it also stipulated that the King must issue writs of election every three years. ${ }^{504}$ The Triennial Act, 1694 started from a baseline of unregulated and absolute prerogative authority over dissolution and came about after the Drift that had occurred after from the Glorious Revolution in 1688 to 1694. This statute provides a good example of Layering on some modest regulations onto the King's prerogative authority and made Parliament a permanent institution that sat more or less continuously. Parliament thus limited the prerogative authority over summoning and dissolution and regulated them by statute, but it did not put them into abeyance.

The Protestant Succession in England and the United Kingdom faced several Jacobite rebellions and uprisings between 1689 and 1745. Amidst this political turmoil, the Septennial 
Act, 1715 extended the maximum life of parliaments from three to seven years in an attempt to provide long-term stability, secure the Hanoverian Succession, and discourage strife. Later in the $19^{\text {th }}$ century, the gradual expansion of the franchise between the Reform Acts of 1832,1868 , and 1884 likewise caused the gradual entrenchment of political parties and strengthened Cabinet Government and the principle of collective ministerial responsibility and ministerial solidarity. This, in turn, sometimes necessitated early dissolution and more frequent general elections instead of mid-parliamentary transitions of power between governments; no parliament during the reign of Queen Victoria lasted its full seven years.

The reigns of Victoria and Edward VII thereby mark a period of Drift toward the system of government that prevailed for the rest of the $20^{\text {th }}$ century. The Parliament Act, 1911, the last example of Layering, simply codified and caped off what had already developed in practice over the preceding fifty years and reduced the maximum life of a parliament to five years and limited the hereditary House of Lords to a suspensive veto. Finally, one century later, the Fixed-Term Parliaments Act, 2011 exemplifies Displacement, because it completely rejected the previous established constitutional positions of the Queen and Prime Minister by putting the British Crown's prerogative authority over dissolution into abeyance and replacing it with a system where parliament is dissolved under the authority of the statute alone. The most radical statute of them all, it goes even farther than did the Long Parliament Act, 1641, which only put the King's authority over dissolution into abeyance for that one parliament and not indefinitely.

\section{What These Statutes Show About the Nature of the Crown's Prerogative Authority}

Hogg et al. acknowledge the legal debate on whether the repeal of a statute that put a prerogative authority into abeyance revives the prerogative; they conclude:

the better view is that prerogative is not revived by the repeal of the replacing statute. A prerogative that has been displaced by statute is best thought of as having been repealed in much the same way as a statute is repealed. ${ }^{505}$

This analogy presents some conceptual problems. The "replacing statute" only puts the prerogative into abeyance and does not eliminate the prerogative source of executive authority outright. The first source of the Crown's authority, the prerogative, dates from the Norman Conquest of 1066 and thus predates any statute that might, from time to time, put some aspects of the prerogative into abeyance. In an architectural analogy, the prerogative would be the support structure of a building, while the statute can be thought of as a façade: the façade can only be constructed after the building, and if the façade is removed, the building's main structure remains in place. Drawing on a slightly different architectural analogy, British constitutional historian Robert Craig calls this the "underground theory," that "prerogative sits underneath statutes like the ground underneath parliament and the statutes are like buildings sitting on top of the ground[...]." ${ }^{, 506}$ Parliament can delegate new statutory authority to the Crown by creating new authorities and functions, and parliament can subsequently repeal the statute that conferred these authorities and functions upon on the Crown, which would indeed eliminate them. But statutes that put prerogatives into abeyance are a special case compared to delegated legislation.

As this case study on the prerogative authority over dissolution demonstrates, when parliament repeals the statute that had put a prerogative into abeyance, the prerogative reasserts 
itself automatically, because certain authorities belong to the executive by necessity. This is an indisputable fact of history. The Triennial Act of 1640 limited the Crown's prerogative authority over dissolution, prorogation and the summoning of parliament; the Act Against Dissolving the Long Parliament Without Its Consent of 1641 put the Crown's authority over all three into abeyance, temporarily, only for the duration of the Long Parliament in which it originated. After the dissolution of the Long Parliament upon the Restoration in 1661, the Triennial Act of 1640, with its limitation on the Crown's authority over dissolution, prorogation, and summoning of parliament, re-entered into force. The Cavalier Parliament passed the second Triennial Act of 1664 and thereby repealed the first Triennial Act of 1640 and thus fully restored the original extent of the Crown's prerogative authority over dissolution and prorogation, and the summoning of parliament. The third Triennial Act of 1694 re-imposed a system similar to the first Triennial Act of 1640 and thus limited and regulated, but did not eliminate, the Crown's authority over dissolution.

In 2011, the British Parliament again put the Crown's authority in dissolution into abeyance through the Fixed-Term Parliaments Act, but left the Crown's authority over prorogation and summoning of parliament intact. However, the British Parliament decided to alter this historical process at Common Law through the Interpretation Act, 1978, which has put into abeyance the former Abeyance Principle such that repealing a statute that replaced a prerogative authority no longer restores the said prerogative authority automatically. ${ }^{507}$

\section{XII: Fixed-Term Parliaments Act, 2011}

\section{Putting the Prerogative of Dissolution into Abeyance}

In 2011, the British Parliament decided once again to put the prerogative of dissolution into abeyance through the Fixed-Term Parliaments Act, 2011 - just as the English Parliament did in principle in 1641. While the Queen used to dissolve parliament sometime within its constitutional limit of five years on the advice of the Prime Minister, this new law now ensures that parliament dissolves automatically by efflux of time, instead of promulgating it by way of an executive instrument. The Parliament elected in 2010 dissolved "at the beginning of the $17^{\text {th }}$ working day before the polling day for the next parliamentary general election," which occurred on 7 May 2015. Each subsequent polling day would normally fall on the first Thursday in May every five years, though the House of Commons supported Prime Minister May's motion for an early general election in 2017. The law allows for some flexibility in setting the voting day; the Prime Minister may issue a statutory instrument to delay the polling day by not more than two months - but only if the Commons and Lords each pass a resolution approving of the draft of the statutory instrument beforehand. ${ }^{508}$

Curiously, the Act contains a non-derogation clause that preserves the Queen's power to prorogue on the advice of the Prime Minister: "This Act does not affect Her Majesty's power to prorogue Parliament." The Act also preserves the conventional (rather than statutory) limits on the prerogative of summoning parliament. After the automatic, statutory dissolution of Parliament, Her Majesty-in-Council must issue a proclamation for the summoning of the new

parliament, which would convene, by convention, within twelve days after voting day. ${ }^{509} \mathrm{In}$ Canada, dissolution still requires a set of three proclamations. The British also recognized that 
they took a different approach from the Canadian model of fixed-date election law. British constitutional historian Robert Hazell wrote on the deficiencies of the Canadian model in his submission to the British parliamentary committee studying the Fixed-Term Parliaments Bill; he described Canadian federal elections as "nominally fixed," precisely because the Harper Government's bill "preserved the prerogative powers of the Crown in order to avoid a constitutional amendment.",

\section{The Old Confidence Convention and the New Constructive Non-Confidence}

In Canada - and in the United Kingdom prior to the passage of the Fixed-Term Parliaments Act, 2011 - a vote of confidence falls under three broad categories: votes on the Address in the Reply to the Speech from the Throne and supply, a motion of want of confidence itself (i.e., "that this House has no confidence in the Government"), both of which are unambiguous votes of confidence, as well as any government bill that the government deems a matter of confidence. ${ }^{511}$ The Government may declare some of its bills matters of confidence before a vote, or the Government could treat the rejection of an important bill on policy as a loss of confidence because of the general principle that the Crown, through its ministers, controls the legislative agenda of the Commons. ${ }^{512}$ This category of confidence vote generated controversy in the recent series of minority parliaments in Canada between 2004 and 2011, where the Government often adopted the tactic of declaring key government bills, particularly those flowing from the Speech from the Throne, matters of confidence in order to provoke the Opposition into withdrawing confidence from the Government, which would in turn seek early dissolution and fresh elections. ${ }^{513}$ A Prime Minister can also acknowledge that the government has lost the confidence of the House of Commons if it has lost control of the legislative agenda.

Under the Canadian system and the British system pre-2011, once the Government has demonstrated that it commands the confidence of the Commons (such as through the Address in Reply to the Speech from the Throne or on any supply bill), it retains that confidence until the moment that the Commons decides to withdraw it in a subsequent formal vote in the chamber. ${ }^{514}$ The Commons expresses its confidence by passing supply and any other major government bill that the government deems a matter of confidence; the Commons can thus withdraw its confidence from the Government by refusing to pass supply or by voting down a bill that the Government has deemed a matter of confidence. Theoretically, the Government could accept the Opposition's amendments to decrease spending in a supply bill without violating the Royal Recommendation, and thus retain the confidence of the Assembly, but Governments in Canada since the $20^{\text {th }}$ century have generally considered any such amendment passed by the Commons tantamount to a loss of confidence. ${ }^{515}$ Generally, the Government judges when it has lost the confidence of the Commons on votes relating to government bills, the Government announces that it has lost the confidence of the Commons on and supply bills and the Address in Reply, but the Commons determines when it has withdrawn confidence from the Government on an unambiguous motion of want of confidence.

The Fixed-Term Parliaments Act, 2011 and constructive non-confidence eliminate two of those three categories of votes of confidence and ensure that the Government no longer possesses the discretion to determine when the Commons has withdrawn its confidence in it; only the Commons can withdraw confidence from the Government through a properly worded motion. In 
a pure constructive motion of non-confidence, the Commons would both withdraw its confidence from the current Government and then propose an alternative government in a single motion, as Canadian Liberal leader Stephane Dion moved on 28 November 2008:

That this House has lost confidence in the current government and is of the opinion that a viable alternative government can be formed within the present House of Commons. ${ }^{516}$

The new procedure under the Fixed-Term Parliaments Act, 2011 allows the Commons to separate the two parts of a pure motion of constructive non-confidence - first, the motion of want of confidence and second, a confirmation vote - and has fundamentally altered the confidence convention in the United Kingdom. Since the Address in Reply to the Speech from the Throne, supply bills, and government bills are no longer matters of confidence ${ }^{517}$, the Commons could vote down the Address in Reply or withhold supply without withdrawing its confidence in the Government. Instead, after voting against the Address in Reply or a supply bill, the Commons would have to pass a proper motion of non-confidence in order to withdraw its confidence from the Government. The Prime Minister can now no longer judge when his government has lost the confidence of the Commons and can therefore no longer advise early dissolution. Constructive non-confidence could not only force MPs to support a Ministry with which they disagree, but also facilitate great constitutional mischief. For instance, the Commons could defeat the Government on the Address in Reply or on a supply bill but still refuse to support a motion "that this House has no confidence in Her Majesty's Government." ${ }^{\text {,18 }}$

The Fixed-Term Parliaments Act, 2011 also sets out two procedures by which Parliament may dissolve itself before the scheduled elections. The first procedure does not touch upon whether the Government still commands the confidence of the Commons, and the second procedure sets out a form of constructive non-confidence. First, Parliament could pass a motion with a two-thirds super-majority in the form, "That there shall be an early parliamentary general election." While the dissolution itself would occur pursuant to the vote and without the involvement of the Crown, the Prime Minister would then have to advise the Queen to issue proclamations for the return of writs and the summoning of the next parliament. Second, the Commons could withdraw its confidence from the Government through a simple majority and properly worded motion, "That this House has no confidence in Her Majesty's Government." If an alternative Government cannot gain the support of the Commons within fourteen days through a confirmation vote on the motion, "That this House has confidence in Her Majesty's Government," then the Parliament dissolves automatically in order to break the impasse. ${ }^{519}$ The defeated government would remain in office but exercise restraint under the caretaker convention during the writ. ${ }^{520}$

As such, votes on the Address in Reply, supply, and major government bills no longer constitute votes of confidence; the Fixed-Term Parliaments Act, 2011 has abolished the old constitutional conventions surrounding questions of confidence and replaced them with new, codified procedures of constructive non-confidence and confirmation voting. The second procedure for early dissolution alludes to the old convention that if the Government loses the confidence of the Commons, the Prime Minister should first consider resignation and allow the Sovereign to commission a new Government that could command the confidence of the Commons, and only advise the early dissolution of the present parliament and the issuance of writs for a new general election as a last resort. ${ }^{521}$ However, it also imposes a variant of 
constructive non-confidence, which ensures that only the Commons possesses the discretion to declare when it has withdrawn its confidence from the Government. In other words, the Government no longer retains the discretion to judge that it has lost the confidence of the Commons; the Commons alone has become the sole arbiter of confidence.

\section{The Cabinet Manual and Fixed-Term Parliaments}

The Fixed-Term Parliaments Act, 2011 has replaced the standard confidence convention with something more similar to a Continental European-style constructive non-confidence. In Canada and in the United Kingdom pre-2011, votes on confidence include votes on the Address in Reply to the Speech from the Throne (or Queen's Speech, as the British call it), on supply bills, and on matters which the government deems a matter of confidence, which would usually be linked to a key policy bill derived from their campaign platform (or manifesto, as the British call it). The Ministry thereby possess some latitude and flexibility on questions of confidence, but the votes on the Address in Reply and supply are, as practical matters, almost automatically and necessarily votes of confidence. So if the Ministry loses such a vote, then the Prime Minister would either have to resign or advise an early dissolution, depending on the circumstances and whether an alternative government could be formed from within the same parliament.

But this is not the case under constructive non-confidence and confirmation voting. Under this system, pioneered in the former West Germany in 1949, the Ministry has no discretion whatever in deeming any vote a question of confidence. The elected assembly alone determines the votes which hold the authority to withdraw confidence in the Ministry, and in some jurisdictions, the assembly must also specify a potential alternative government in the same motion. Confirmation voting refers to the practice whereby the elected assembly votes directly on which individual should become Prime Minister; the Sovereign, President, or Speaker (depending on the country) would then be bound to appoint this person as Prime Minister. The Fixed-Term Parliaments Act draws upon these two Continental European methods in determining how the House of Commons can withdraw its confidence from Her Majesty's Government and replace it with a new set of ministers.

The Fixed-Term Parliaments Act allows only one possible method by which the Commons can withdraw its confidence from the Ministry: on a motion, which would have to pass by simple majority, "That this House has confidence in Her Majesty's Government." In other words, if the Commons in this minority $57^{\text {th }}$ Parliament had voted against the May government's first Queen Speech or supply bill, this would not have meant that the Commons has automatically withdrawn its confidence from the Conservative minority government. Instead, the Commons would then have to support, by simple majority, the aforesaid motion in a separate vote. There is no longer such a thing as automatic loss of confidence. If the Commons passes the motion "That this House has no confidence in Her Majesty's Government," then the Fixed-Term Parliaments Act gives MPs fourteen days in which to propose an alternative government and approve it through a motion worded "That this House has confidence in Her Majesty's Government." If the Commons fails to do so within 14 days, the Parliament will automatically dissolve in order to break the deadlock. This procedure essentially breaks the German-style constructive non-confidence into two steps. It sounds reasonable in principle, but it has never been tested in practice. 
The text of the Fixed-Term Parliaments Act and the procedure which it lays out suggests that the incumbent Prime Minister would first have to tender her resignation to the Queen and that the Queen would then have to appoint a new Ministry based on whatever agreements the relevant political parties can form. And only after the Queen appoints the new ministry would the Commons be able to hold the second vote on the motion "That his House has confidence in Her Majesty's Government." Logically, this is the only possible procedure for a mid-parliamentary change of government, because the Commons could not vote on the motion "That his House has confidence in Her Majesty's Government" with reference to the potential alternative Ministry before it takes office. Therefore, the procedure under the Fixed-Term Parliaments Act does not amount to a confirmation vote in the same way as the German method, because the order of events (parliamentary vote and appointment of a new Ministry) is reversed.

The President of Germany appoints the Chancellor of Germany in accordance with the confirmation vote of the Bundestag in accordance with Article 63 of the Basic Law. But in the United Kingdom, the incumbent Prime Minister would have to resign after losing the vote of confidence, the Queen would then have to appoint a new Prime Minister and ministry, and the House of Commons would, in turn, effectively ratify the new ministry through the motion "That this House has confidence in Her Majesty's Government." But if the Commons still refused to support this new Ministry, then the Parliament would be dissolved after fourteen days of the Commons having withdrawn its confidence in the first Ministry, and this new Ministry would then become a caretaker during the subsequent general election.

The Cabinet Manual outlines some of these scenarios very briefly, but it does not specify precisely how the order of events would take place. In fairness, this was probably intentional; the Cabinet Office did not design the Cabinet Manual as an exhaustive list of every possible permutation of events - which would, at any rate, have been impossible. But there is another scenario, to which the Cabinet Manual does allude. It is also possible that the incumbent Prime Minister would not resign immediately after losing the vote on the motion "That this House has no confidence in Her Majesty's Government" but would enter into negotiations with the other parties and form a supply agreement or coalition with one or more of them, at which point the Commons would signify its approval by voting in favour of the motion "That his House has confidence in Her Majesty's Government."

Change of Prime Minister or government during a Parliament

2.18 Where a Prime Minister chooses to resign from his or her individual position at a time when his or her administration has an overall majority in the House of Commons, it is for the party or parties in government to identify who can be chosen as the successor.

2.19 Under the Fixed-term Parliaments Act 2011, if a government is defeated on a motion that 'this House has no confidence in Her Majesty's Government', there in then a 14-day period during which an alternative government can be formed from the House of Commons as presently constituted, or the incumbent government can seek to regain the confidence of the House. If no government can secure the confidence of the House of Commons during that period, through the approval of a motion that 'this House has confidence in Her Majesty's Government', a general election will take place. Other decisions of the House of Commons which have previously been regarded as expressing 'no confidence' in the government no longer enable or require the Prime Minister to hold a general election. The Prime Minister is expected to resign where it is clear that 
he or she does not have the confidence of the House of Commons and that an alternative government does have the confidence. ${ }^{522}$

The last sentence of paragraph 2.19 means that the Prime Minister would not and should not put the Queen in a politically awkward position where she would not be able to uphold her primary duty of insuring that there is always a duly constituted Ministry in office to carry out the business of government. As such, incumbent governments must stay on until a viable government which the Queen can appoint as an alternative becomes clear. But under the FixedTerm Parliaments Act, it is now only clear that an incumbent government does not command the confidence of the Commons once the Commons withdraws its confidence from the government, and it is only clear that a potential alternative government could command the confidence of the Commons after it wins an affirmative vote of confidence.

The Cabinet Manual acknowledges the fact that the votes on the Address in Reply and on supply no longer amount to automatic votes of confidence, because the Commons can now only withdraw its confidence from the Ministry under the Fixed-Term Parliaments Act. The concluding sentence alludes to something akin to constructive non-confidence. The best interpretation is that the PM should only resign if an alternative government can be formed midparliament. In other words, the Prime Minister would resign after the Commons has passed the motion "That this House has no confidence in Her Majesty's Government" and where the incumbent government could not possibly regain the confidence of the Commons. The incumbent Prime Minister's resignation would thus pave the way for the Queen to appoint a new government and for the House of Commons to support the motion "That this House has confidence in Her Majesty's Government" within fourteen days.

Alternatively, the last sentence could plausibly be interpreted to mean that even this new system does not preclude the Prime Minister (and thus the Ministry as a whole) from resigning anyway if the House of Commons did vote down the Address in Reply to the Queen's Speech, a money bill, or a key policy bill. And such a course of action would only serve to highlight the redundancy of the Fixed-Term Parliaments Act, since governments would have resigned or advised early dissolution under those same circumstances before that legislation entered into force. On the other hand, the Government could also undertake a political response under the framework of the Fixed-Term Parliaments Act by tabling an affirmative motion "That this House has confidence in Her Majesty's Government" and daring the Commons to vote against it and precipitate an early dissolution.

In general, the Fixed-Term Parliaments Act also raises an interesting paradox about how a Ministry holds the confidence of the Commons under this new semi-Continental European system. The Act specifies the one condition upon which a Ministry can lose the confidence of Commons, and it spells out the means by which a new Ministry gains the confidence of the Commons. But it is silent on whether or how an incumbent government commands, loses, or gains the confidence of the Commons. The only logical conclusion is that the absence of nonconfidence now signifies confidence. This state of affairs reverses the onus and inverts the intent of the classical Westminster system wherein the government - incumbent or new - must affirmatively demonstrate that it commands the confidence of the Commons by winning crucial votes like that on the Address in Reply and supply. 
This paradox applied in the $56^{\text {th }}$ Parliament, elected in 2015 and dissolved in 2017. David Cameron's Conservatives and Nick Clegg's Liberal-Democrats formed a coalition government in 2010, before the Fixed-Term Parliaments Act entered into force. But after David Cameron led the Conservative and Unionist Party to an unexpected victory and parliamentary majority in 2015, his continuing tenure as Prime Minister did not depend in any way upon the House of Commons in the $56^{\text {th }}$ Parliament passing the motion "That this House has confidence in Her Majesty's Government." And since votes on the Address in Reply to the Queen's Speech and supply bills no longer constitute votes of confidence, the Cameron government never gained the confidence of the Commons through those old means either, as British governments did pre2011.

Theresa May now faces the same situation. Under May's incompetent leadership and disastrous campaign - the worst since Ted Heath's "Who Governs?" campaign of 1974 - the Conservatives lost the parliamentary majority that Cameron had won them in 2015 and now only command a plurality of seats. But even if May's minority government had lost votes on the Address in Reply to the Queen's Speech in 2017, this alone would not have automatically translated into a loss of the confidence of the Commons. Instead, the Commons would then have to take action and pass a motion of non-confidence under the Fixed-Term Parliaments Act. So the May government will command the confidence of the Commons unless and until the Commons expressly withdraws its confidence, even if the Ministry had lost crucial votes that used to be questions of confidence pre-2011.

\section{The Subversiveness of the Fixed-Term Parliaments Act}

This radical break with tradition would allow British MPs to vote against money bills but still formally retain their confidence in the Government. Such an arrangement would destroy Responsible Government by severing the link between the government, the parliament, and expenditures. Governments implement many of their policies by spending public money, so it would be inherently irresponsible and hypocritical for an MP to express confidence in the government but then vote against its main policies. In practice, the politics of consensus and coalition government would have to fill this void, but the United Kingdom lacks this continental European tradition. Bogdanor argued that constructive non-confidence could "make it difficult to remove a lame-duck government", even if a simple majority of MPs, but not a two-thirds supermajority, want an early dissolution. ${ }^{523}$

The House of Lords did not seem to appreciate the radicalism that the Cameron-Clegg Government had injected into the bill. In its report on the Fixed-Term Parliaments Bill, the Lords noted:

The Bill as drafted does not explicitly cover all motions of confidence (including defeats on key confidence issues such as the Queen's Speech or the Budget), nor situations where the government lose[s] a vote. Nor does it distinguish between votes of confidence and no confidence. The Government should bring forward amendments to clarify its precise scope. ${ }^{524}$

In its official response to the Commons and Lords committees, the Cameron-Clegg Government demonstrated a disturbing misinterpretation of its own legislation and also failed to grasp the extent of its radicalism: 
In the circumstances the Committee envisages, where a Government has been formed after a general election, or when a Prime Minister has been replaced mid-term, some form of motion which could be construed as a question of confidence will occur in the normal course of business.

For example, the debates on the Queen's Speech act effectively as an endorsement of a

Government's programme. The Bill does nothing to change this fact. ${ }^{525}$

Contrary to the Government's response, the Fixed-Term Parliaments Act has changed this fact. Its deliberately sets out a new procedure for constructive non-confidence and confirmation voting such that votes on the Address in Reply to the Queen's Speech and on supply bills are no longer automatically regarded as motions of confidence. In addition, this procedure has abolished the Government's authority to determine what qualifies as a vote of confidence outside of an express motion of non-confidence proposed by the Commons. ${ }^{526}$ As such, the Commons could vote against the Address in Reply or a supply bill without automatically withdrawing its confidence from the Government. Section 2 of the Fixed-Term Parliaments Act, 2011 makes clear that the Commons can only withdraw its confidence from the Government by passing a motion, "That this House has no confidence in Her Majesty's Government." The Commons could vote against the Address in Reply or a supply bill, but it would then also have to pass that unambiguous motion of non-confidence in order to oust the Government. What once happened efficiently and practically in one step now requires two officious, cumbersome stumbles.

The Government also made the extraordinary claim that the Fixed-Term Parliaments Act, 2011 does not alter the confidence convention - despite the fact that it has eliminated two categories of votes of confidence and replaced them with a codified procedure on constructive non-confidence, confirmation votes, and early dissolution:

The Bill is focussed on establishing fixed terms and the procedures for calling extraordinary elections. The aim of the Bill is not otherwise to interfere with the conventions which govern the position where the Government loses the confidence of the House. The Government considers that such matters are better left to convention. ${ }^{527}[\ldots]$

It is not easy to define precisely when, after the passing of a motion of no confidence in it, a Government should resign or remain to contest a general election. This is the reason why this matter is best left to convention.

In reality, the whole point of the Fixed-Term Parliaments Act is that it rejects the old practical constitutional conventions and imposes in their stead a new set of fussy procedures codified in statute. Even Bogdanor failed to fathom the radicalism of this provision:

It is, however, by no means always clear what is to count as a vote of confidence. Clearly an explicit vote of confidence or a defeat on the budget or the Queen's Speech must involve the government's resignation. But a government may choose to require a quite ordinary motion as a vote of confidence. ${ }^{528}$

In reality, the Fixed-Term Parliaments Act, 2011 has codified a new procedure for votes of non-confidence in order to deal with "calling extraordinary elections" and stabilize the lifecycle of parliament. Therefore, this statute does necessarily and deliberately "interfere with the conventions which government the position where the Government loses the confidence of the House," despite the Government's intention. Prior to the passage of this act, if the Commons had withdrawn its confidence from the Government, the Prime Minister could tender his resignation so that the Queen could appoint a new government; alternatively, the Prime Minister 
could advise the Queen to dissolve parliament. However, the Prime Minister can no longer exercise the latter option because the Fixed-Term Parliaments Act, 2011 has put the prerogative authority over dissolution into abeyance. Under the terms of the new law, the Government would remain in office for, at most, 14 days after losing a direct vote of non-confidence, during which time the Commons would attempt to form an alternative government. If the Commons could not support an alternative government from within the same Parliament after 14 days, then the Parliament would have to be dissolved in order to break the deadlock. The incumbent Government would remain in office during the writ and limit itself to a caretaker capacity, as it would have before the Fixed-Term Parliaments Act, 2011.

Contrary to the Government's claim, the Fixed-Term Parliaments Act has undoubtedly altered the established constitutional conventions on confidence matters. The Government no longer decides whether to "remain to contest a general election" because the Commons would now make that determination. The Cameron-Clegg Government made the mistake of appealing for protection to the very same constitutional conventions that the Fixed-Term Parliaments Act, 2011 has abolished or altered and replaced with a new system of codified rules. The CameronClegg Government's official response clearly illustrates that it did not fully comprehend the implications and radicalism of its own bill. In contrast, most Canadian governments overestimated the significance the reforms presented in their fixed-date election bills, which all preserved the established constitutional positions of the Governor and First Minister and the confidence convention.

The Government might have misinterpreted the provisions on constructive nonconfidence and what exactly constitutes a matter of confidence because of a particular amendment to the Fixed-Term Parliaments Bill. When Deputy Prime Minister Nick Clegg first introduced the bill in the House of Commons, section 2 made the two procedures for early dissolution subject to a Speaker's certificate, which would have officially designated, at the behest of the Commons, the votes on the early dissolution by super-majority and the strict motion of non-confidence as matters of confidence. The Government later removed this procedure on Speaker's certificates at the behest of the Clerk of the House and the parliamentary committees; the Fixed-Term Parliaments Act, 2011 now leaves these motions entirely up to the House of Commons itself. The Speaker's certificates would have "certif[ied] that the House has passed a motion that there should be an early parliamentary general election" and "that on a specified day the House passed a motion of no confidence in Her Majesty's Government (as then constituted)." ${ }^{, 529}$ This procedure of Speaker's certification might have allowed the Commons to withdraw its confidence from the Government by voting against the Address in Reply or a supply bill, provided that the Speaker certified such votes as motions of confidence. The Government seems to have taken this position in its official response to the Commons and Lords committees:

We recognise that there are a variety of means by which the House may move that it does not have confidence in the Government. The Bill provides that it will be for the Speaker to certify what passing a motion of non-confidence in a Government is, thus leaving the matter within the exclusive cognisance of the House. ${ }^{530}$ 
Without the procedure of Speaker's certificates, however, only a vote on a motion "That this House has no confidence in Her Majesty's Government" amounts to a vote of want of confidence.

The Political and Constitutional Reform Committee of the British House of Commons quite rightly also noted some other ambiguities contained in the partial codification in the FixedTerm Parliaments Act, 2011:

\begin{abstract}
Only if the House resolved specifically that if had no confidence in the Government would there be the possibility of an early general election. This could play into the hands of an Opposition wanting to force a minority government to resign without wanting to face the possibility of any early general election: it could simply make the Government's life impossible while avoiding tabling an explicit motion of no confidence. ${ }^{531}$
\end{abstract}

The Committee therefore recommended that the Fixed-Term Parliaments Act contain provisions specifying "the circumstances in which a government losing the confidence of the House could trigger an early general election, and those circumstances, if any, in which it could not." ${ }^{, 52}$ The Committee also noted that a single-party majority government could also take advantage of the Act "by tabling and voting for a motion of no confidence in itself in order to trigger an early general election," thus by-passing the alternative procedure for early dissolution that requires a supermajority of two-thirds. ${ }^{533}$ In practice, as we saw in 2017 , the incumbent government would use the other procedure for early dissolution and the opposition would lend its support to the two-thirds super-majority required for early dissolution without a vote of nonconfidence.

The Commons committee further observed that the Government could postpone or avoid the 14-day caretaker period through prorogation, which would ensure that the Commons could not sit and therefore could not carry out a vote of constructive non-confidence and confirmation vote for a new government. Labour MP Chris Bryant, then the Shadow Minister for Political and Constitutional Reform, proposed an amendment to the Fixed-Term Parliaments Bill that would have put the Crown's authority over prorogation into abeyance along with the Crown's authority over dissolution and substituted a new codified procedure whereby the Speaker would declare parliament prorogued based on a "resolution" of the House of Commons. ${ }^{534}$ Bryant agreed with the Political and Constitutional Reform Committee and suggested that under the procedures for constructive non-confidence and confirmation voting, the Government could seek prorogation in order to prevent an alternative government from being formed, and thus force an early dissolution. ${ }^{535}$ Bryant even cited Prime Minister Harper's tactical prorogations in 2008 and 2009 as evidence that a British Prime Minister might do the same!

In its official response, the Government accepted the premise of this argument and acknowledged that the Prime Minister could "frustrate attempts to form an alternative Government" by advising the Queen to prorogue parliament and that the prorogation "would not stop the clock on the 14-day government formation period, and an election would therefore result." ${ }^{, 536}$ But the Government rejected the view that the Crown's authority over prorogation should also be curtailed by appealing to the political enforceability of constitutional conventions: such "political gamesmanship [...] would result only in a damning verdict from the electorate." political safeguards in our constitution should not be underestimated" with respect to prorogation 
but on the other hand introduce a bill that puts the Crown's authority over dissolution into abeyance in order to "remove the right of a Prime Minister to seek the dissolution of Parliament for pure political gain." 538 Logically, if a Prime Minister who uses prorogation as a political tactic would face a "damning verdict from the electorate," then so too should a Prime Minister who uses dissolution and a snap election as a political tactic; in that case, the Fixed-Term Parliaments Act, 2011 itself, which now precludes the latter possibility, would amount to an over-reaction or a solution to a non-existent problem. Instead, the Government promoted the Fixed-Term Parliaments Act as "a significant and unprecedented surrender of executive power" that would ensure "greater stability in the political system.",539

In addition, the Government's response regarding the tactical use of prorogation overlooks some important considerations. If the Government lost the confidence of the Commons through a vote on the motion, "That this House has no confidence in Her Majesty's Government", as per the terms of the Fixed-Term Parliaments Act, 2011, then it could very well postpone or delay its defeat through prorogation. The Government argues that prorogation would not stop the clock on the 14-day timeframe in which the Commons could form a new government through a confirmation vote and that therefore the Parliament would dissolve automatically under the terms of the Act. But if the Parliament is prorogued, then the House of Commons could no longer convene within the 14-day period in order to hold the confirmation vote "That this House has confidence in Her Majesty's Government" for an alternative government and thus could no longer prevent the possibility of an early dissolution that occurs automatically after those 14 days elapse.

In short, a British Government could use prorogation as a tactic not merely to postpone a vote of confidence from within a new session of the same Parliament, as Prime Minister Harper did in 2008 and $2009^{540}$, but as a method of preventing a vote of confidence from a new session of the same Parliament. A defeat on the motion "That this House has no confidence in Her Majesty's Government" combined with a prorogation immediately thereafter would prevent the Commons from forming an alternative government and carrying out a confirmation vote within the 14-day period and would thus inevitably lead to an early dissolution. However, the FixedTerm Parliaments Act was designed to contain only one method of guaranteeing an early election, whereby at least two-thirds of MPs support a motion "That there shall be an early parliamentary general election." Ironically, the Fixed-Term Parliaments Act, by putting the Crown's authority over dissolution into abeyance but by explicitly preserving the Crown's authority over prorogation, has increased the political and tactical value of a well-timed prorogation.

\section{Analysis of the British Model of Fixed-Term Parliaments and the Political Motivation} Behind the Law

The Westminster Parliament first created the precedent for fixed-term parliaments and putting the Crown's authority over dissolution into abeyance through the Scotland Act, 1998, which created the devolved legislature for Scotland. The Scotland Act mandates that the Scottish Parliament dissolve and summon itself automatically every four years such that the elections occur on the first Thursday in May, and the new parliament convenes seven days later. ${ }^{541}$ This system of fixed-term parliaments obviates the need for dissolution as an executive prerogative. 
"Extraordinary general elections" can only take place if and only if two-thirds of MPs vote in favour of holding an early general election. The Scotland Act, 1998 also sets up a procedure of confirmation votes for the Scottish "First Minister." The parliament "nominates one of its members for appointment as First Minister," after which the Queen of the United Kingdom formally commissions that individual to form a government. The Scottish Parliament also relies on a system of fixed calendars, rather like the US House of Representatives, which obviates the need for prorogation altogether.

The Political and Constitutional Reform Committee of the British House of Commons pledged to "examine as part of a future inquiry the possibility of the House formally endorsing a new government, after a general election and in other circumstances." 542 In other words, the committee would support extending the principle of confirmation votes to all "new governments", while the current procedure only requires a confirmation vote through the motion "That this House has confidence in Her Majesty's Government" after a mid-parliamentary change of government. Taken together, these two measures would implement constructive nonconfidence as the general rule for all cases. The committee did not specify whether an incumbent government that retains its parliamentary majority from one parliament to another would also have to obtain a confirmation vote. The Political and Constitutional Reform Committee concluded its report on the Fixed-Term Parliaments Bill with a veiled threat against the Crown's prerogative authority in general: "We expect to consider the prerogative powers and Executive power more generally in the course of our scrutiny of wider constitutional issues." $" 543$

The British House of Commons might follow through on this threat and decide to put the prerogative authority over the summoning and prorogation of parliament into abeyance, either through fixed calendars or through an amendment to the Fixed-Term Parliaments Act, 2011 along the lines of Chris Bryant's model. The United Kingdom has set itself on a new course of Europeanizing its Crown by curtailing the executive prerogative authority and replacing it with codified statutory authority. This radicalism ultimately derives from New Labour and the Brown Government's Green Paper on The Governance of Britain from 2007, in which Prime Minister Gordon Brown and Lord Chancellor Jack Straw sought to "forge a new relationship between government and citizen, and begin the journey towards a new constitutional settlement - a settlement that entrusts Parliament and the people with more power." ${ }^{544}$ The Brown government argued:

For centuries the executive has, in certain areas, been able to exercise authority in the name of the Monarch without the people and their elected representatives in their Parliament being consulted. This is no longer appropriate in a modern democracy. The Government believes that the executive should draw its powers from the people, through Parliament. ${ }^{545}$

In 2010, the Labour Party followed through on the Governance of Britain and pledged to introduce "legislation to ensure [that] Parliament sit[s] for a fixed term." 546 The LiberalDemocrats and the Conservatives have since accepted the premise of that report, at least with respect to the prerogative authority over dissolution. In the 2010 election, the Liberal Democrats pledged to "introduce fixed-term parliaments to ensure that the Prime Minister of the day cannot change the date of an election to suit themselves [sic]." 547 The Conservative Party did not include such a commitment in its manifesto; however, David Cameron did advocate during that election for legislation that "require a general election within six months of a new party leader taking 
over as Prime Minister, following the death or resignation of the previous incumbent." Newfoundland and Labrador adopted precisely this model in its fixed-date election law in 2004. Perhaps Cameron advocated for the Newfoundland model because he had dared Gordon Brown to call an early election upon his appointment as Prime Minister in $2007 .{ }^{549}$ As shown in a previous section, opposition leaders in Canada have also called upon First Ministers appointed mid-parliament to ask for early elections.

The minority parliament elected in 2010 only gave the Conservatives a plurality of the seats, and the Conservatives and Liberal Democrats opted to form a coalition government. The Fixed-Term Parliaments Act, 2011 therefore provided a convenient political tool to ensure the survival of the Conservative-Liberal coalition government, as the two parties openly acknowledged in their initial governing agreement:

\section{We expect [the coalition government] to endure for the duration of the present Parliament. The Government will put a motion before the House of Commons in the first days of the Government stating its intention that, subject to Her Majesty The Queen's consent, the next General Election will be held on 7 May 2015, to be followed by legislation for fixed term Parliaments of five years. ${ }^{550}$}

The Liberal-Democrats considered a fixed-term parliament "an essential precondition of coalition." 551 Echoing the Canadian rationale for fixed-date election laws, the British House of Commons Standing Committee on Political and Constitutional Reform studied the Fixed-Term Parliaments Bill and declared, "it is wrong that a Prime Minister should be able to time a general election to his own partisan advantage., 552

Given the internal turmoil that the Cameron-Clegg government faced over issues such as the referendum on electoral reform and the contradictory Conservative and Liberal-Democratic positions on the United Kingdom's position in the European Union, the Fixed-Term Parliaments Act, 2011 almost certainly propped up the Cameron-Clegg Coalition, because an immediate early dissolution can now only occur if at least two-thirds of MPs vote in favour of a motion "That there shall be an early parliamentary general election." Therefore, like the Canadian laws, the British law has served primarily a political purpose. As Robert Blackburn argued, "The catalyst for the Fixed-Term Parliament Bill has been a mutual desire between the two Coalition government party leaders to fix the duration of their inter-party alliance." ${ }^{, 53}$ The LiberalDemocrats insisted on the Fixed-Term Parliaments Act so that Prime Minister Cameron could not advise an early dissolution when he thought that his Conservative Party would stand to gain a parliamentary majority. ${ }^{554}$ Jack Straw, a Labour cabinet minister under the Blair and Brown governments, stated in the Commons that the law would "serve as a form of constitutional handcuffs to prevent either of the coalition parties from assassinating the other."

Furthermore, the Fixed-Term Parliaments Act also largely insulated the Prime Minister May from the consequences of leading the Conservative and Unionist Party to a loss, from majority to plurality, and provided a secure foundation for the agreement with the Democratic Unionist Party. 


\section{The Early Dissolution and General Election of 2017}

$\underline{\text { Introduction }}$

On 18 April 2017, Prime Minister Theresa May announced that she would seek an early general election under the terms of the Fixed-Term Parliaments Act in order to reaffirm her mandate to manage the United Kingdom's secession from the European Union under Article 50 of the Treaty of Lisbon and the European Union (Notification of Withdrawal) Act. ${ }^{556}$ On 19 April, May tabled the motion "That there shall be an early parliamentary general election," and it won the support of $522 \mathrm{MPs}$, putting it well above the two-thirds super-majority that the FixedTerm Parliaments Act requires. As per usual British practice, the parliament entered a "wash up" phase, where it spends a week or so passing any remaining non-controversial and perfunctory legislation on which the government and opposition can agree. Finally, the $56^{\text {th }}$ Parliament dissolved on 3 May 2017 pursuant to section 2(2) of the Fixed-Term Parliaments Act, and the general election itself occurred on 8 June 2017 under section 3(1). ${ }^{557}$ The proclamation promulgated on 25 April 2017 merely recognizes that the Fixed-Term Parliaments Act itself caused parliament to be dissolved and that Prime Minister May only advised the Queen to formally summon the next parliament:

We in pursuance of section 2(7) of the Fixed-term Parliaments Act 2011, on the advice of Our Prime Minister, do hereby appoint Thursday the 8th day of June 2017 as the polling day for the next parliamentary general election. ${ }^{558}$

The British Prime Minister and Queen no longer play any role in promulgating dissolution into force; only the Fixed-Term Parliaments Act itself now does so. Prime Minister May acknowledged as much in the statement which she delivered outside of Number 10 Downing Street on 3 May:

I have just been to Buckingham Palace for an audience with Her Majesty the Queen to mark the dissolution of this parliament. The 2015 parliament is now at an end, and in 36 days, the country will elect a new government and choose the next Prime Minister. ${ }^{559}$

Their audience marked dissolution rather than having promulgated it.

Jeremy Corbyn and Jacob Rees-Mogg Expose the Futility of the Fixed-Term Parliaments Act

Two disarmingly simple comments by Conservative MP Jacob Rees-Mogg, who has consistently opposed the Fixed-Term Parliaments Act and voted against it in the $55^{\text {th }}$ Parliament (2010-2015), and Jeremy Corbyn, leader of the Labour Party, have exposed the futility of the Fixed-Term Parliaments Act. It does not create absolute certainty in the timing of general elections, and it does nothing to change the incentives that drive partisan politics. In fact, even Aucoin et al. have over-estimated what good a Canadian equivalent of the Fixed-Term Parliaments Act could do.

On 19 April 2017, during the debate over Prime Minister May's motion that there be an early general election, Conservative MP Peter Bone pointed out that the motion for an early general election had put the opposition in an intolerable political bind which would force them to vote in favour of said early general election: 
If the House does not agree to a general election, it will not happen and the Government will continue in office. Any Opposition Members who did not want a general election would be very strange creatures indeed. Any Opposition Members who sat on their hands and did not vote would be regarded as impotent Members of Parliament. ${ }^{560}$

Rees-Mogg then posed a rhetorical question to his Conservative colleague, revealing that he was right all along about this dreadful legislation:

But does this not demonstrate why the Fixed-term Parliaments Act can never work? No Opposition can sensibly say that they would prefer a Government they oppose to continue in office, rather than having a chance to defeat them. The Act does not therefore fit within our constitution, and it ought to go. ${ }^{561}$

Sadly, Peter Bone did not seem to grasp the significance and obviousness of Rees-Mogg's statement. He replied:

I rarely disagree with my hon. Friend, but I believe that these events are proof that the Act is working. I believe that we will have the required majority. [...] Despite the party politics, this is a great day for Parliament and a small step forward for parliamentary democracy. ${ }^{562}$

Rees-Mogg was not suggesting that the motion would fail to attain the required twothirds super-majority — to the contrary, he was saying that it would be inconceivable that such a motion would not meet that threshold. And this, in turn, exposes the Fixed-Term Parliaments Act's uselessness and futility as a means of preventing early general elections. While the legislation does make holding early elections slightly more difficult, the events of 2017 expose the fundamental flaw in the reasoning of proponents of the Fixed-Term Parliaments Act in the United Kingdom and proponents of peddling similar nonsense in Canada: they argue that making early elections subject to the approval of the opposition, by requiring a super-majority of MPs to vote in favour of one, would somehow prevent early dissolution and general elections from happening. Experience has now demonstrated that this view is false. Even the proponents of the Fixed-Term Parliaments Act unwittingly and directly address the simple reason why relying on the opposition to stop early elections is a fool's errand: opposition MPs could not plausibly oppose a motion to trigger an early general election without looking cowardly, weak, and ineffectual and without tacitly acknowledging that their parties could not do well enough at the polls to form government.

Labour Party Leader Jeremy Corbyn appeared on Andrew Marr's show on the BBC on 23 April 2017 and confirmed Rees-Mogg's interpretation. Marr pointed out that Corbyn's Labour Party could, in theory, have prevented this early general election from happening by voting against Prime Minister May's motion "That there be an early parliamentary election" and thereby denying the motion the two-thirds super-majority that it required. Marr asked, "You could have stopped it [the early election] happening though, and you didn't. Why?" Unusually for him, Corbyn gave a very simple and straightforward answer in an incredulous retort because this idea struck him as so obvious: "Because opposition parties want to be in government."563 Indubitably! In Westminster parliamentarism, Her Majesty's Loyal Opposition acts as an alternative government, or government-in-waiting, and thus seizes upon any opportunity to form government itself. Supporting Prime Minister May's motion for an early general election offered the Labour Party the best means of achieving its objective of forming government. The leader of 
Liberal-Democrats, Tim Farren, similarly expressed his support in principle for an early general election on social media right after May had first floated the idea. ${ }^{564}$

John Pepall advanced a similar argument in his under-rated book Against Reform: even Continental European-style fixed-term parliaments laws do not prevent a government, which is determined enough, from finding a way of defeating itself and obtaining the early general election that it so desires. Article 38 of Germany's Basic Law provides that elections to the Bundestag take place on fixed terms every four years. However, Articles 67 and 68 of the Basic Law provide a loophole similar to one of the procedures in section 2 of the Fixed-Term Parliaments Act (but not that which May used). Governments can be replaced mid-parliament only through votes of constructive non-confidence under Article 67. But under Article 68, the Chancellor can arrange for the defeat of his own government by ensuring that some of his own supporters abstain from a crucial vote and thereby produce an artificial defeat:

Where a motion of the Chancellor for a vote of confidence is not carried by the majority of the members of the House of Representatives [Bundestag], the President may, upon the proposal of the Chancellor, dissolve the House of Representatives [Bundestag] within twenty-one days. The right of dissolution lapses as soon as the House of Representatives [Bundestag] elects another Chancellor with the majority of its members. ${ }^{565}$

This is precisely what Helmut Kohl did in 1983 and what Gerhard Schroder did in $2005 .^{566}$ Kohl went on to serve as Chancellor of West Germany until 1990 and continued uninterrupted as Chancellor of the unified Federal Republic of Germany until 1998. Schroder soon found himself replaced by Angela Merkel. While Continental European-style fixed-term parliament laws, of which the Fixed-Term Parliament Act is an example, can make early dissolution more difficult in theory, they only make obtaining a dissolution slightly more difficult in practice. And in principle, they do nothing to change the incentives under which political parties operate in Westminster systems: the government wants to stay in government, and the opposition wants to become the government. The Canadian proponents of this legislation have failed to demonstrate that they appreciate and fully grasp that crucial point.

The Indecisive and Unclear Outcome of the Early General Election of 2017

The results of the British General Election of 2017 are strangely anti-climactic and mark a resurgence of the two-party system of Conservatives versus Labour. Both parties saw their share of the popular vote increase, Labour's by fully $9.5 \%$ and the Conservatives' by $5.5 \%$. The two-party system also made a comeback in Northern Ireland, where the more moderate Ulster Unionist Party (the Anglican party) lost two seats, and the more hardline Democratic Unionist Party (the Presbyterian party) picked up two seats; similarly, the Social Democratic and Labour Party lost three seats, and the left-wing and Catholic Irish nationalist Sinn Fein picked up three seats. ${ }^{567}$ But despite the gains in the popular vote, the Conservatives, overall, lost 18 seats. In the general election of 2015, the Conservatives won a narrow majority of 336 seats with $36.9 \%$ of the popular vote. ${ }^{568}$ In May's early election of 2017 , the Conservatives held on to only 318 seats — losing 21 in England and 3 in Wales, but gaining 12 in Scotland. ${ }^{569}$ Jeremy Corbyn, Labour's dour socialist ascetic leader, succeeded: he proved his critics wrong simply by not being a disaster and even managed to lead his party to an additional 29 seats, going from 232 in 2015 to 261 in 2017. He has gained political capital and secured his leadership of the Labour Party. 
A shell-shocked May spoke outside of Number 10 Downing Street on 9 June 2017 and

said:

I have just been to see Her Majesty the Queen, and I will now form a government. A government that can provide certainty and lead Britain forward at this critical time for our country. This government will guide the country through the crucial Brexit talks that begin in just 10 days and deliver on the will of the British people by taking the United Kingdom out the European Union. $[\ldots]$

\begin{abstract}
What the country needs more than ever is certainty. Having secured the largest number of votes and greatest number of seats in this election, it is clear that only the Conservative and Unionist Party has the legitimacy and ability to provide that certainty by commanding a majority in the House of Commons. As we do, we will continue to work with our friends and allies in the Democratic Unionist Party in particular. Our two parties have enjoyed a strong relationship over many years, and this gives me the confidence to believe that we will be able to work together in the interest of the whole United Kingdom. ${ }^{570}$
\end{abstract}

The Westminster Parliament consists of 650 seats, which makes winning 326 seats the threshold for forming a parliamentary majority. However, Sinn Fein MPs elected in Northern Ireland have consistently refused to take their seats at Westminster, because they refuse to swear the oath of allegiance to the Queen of the United Kingdom. In this respect, Sinn Fein MPs-elect are far more principled that Bloc Quebecois MPs here in Canada, who have shown no qualms with advocating socialism, secessionism, republicanism, and, to top it all off, an instrumental and gross hypocrisy by also swearing allegiance to the Queen of Canada. Sinn Fein won 7 of Northern Ireland's 18 seats. Subtracting 7 from 650 yields 643, and dividing that in half and rounding up the remainder means that in this $57^{\text {th }}$ Parliament, 322 seats constitute a majority. The Conservatives won 318, and the Democratic Unionist Party - the socially conservative, proBrexit, Presbyterian party of the late Ian Paisley, Sr. - won 10 seats in Northern Ireland and has, historically, supported its sister Conservative and Unionist Party of Great Britain. The May government therefore decided to enter into a formal supply agreement with the DUP, which would gave the government the support of $328 \mathrm{MPs}$, or a working majority of 6 - small even in the House of Commons of Canada amidst strong Canadian party discipline and very precarious indeed in the British House of Commons.

The Conservative and Unionist Party and the Democratic Unionist Party negotiated a supply agreement that would give May's minority government a parliamentary majority; the parties then released the Confidence and Supply Agreement between the Conservative Party and the DUP. ${ }^{571}$ It is reasonable to presume that this document would have been vetted by officials who understand the implications of the Fixed-Term Parliaments Act. This probably explains why the agreement separates "all motions of confidence" from the other categories of legislation which used to be automatic and de facto votes of confidence. It opts for, specifically, "motions of confidence" - not the more common phrasing "matters of confidence." Before the Fixed-Term Parliaments Act, such an accord in which one minor party agrees to support another larger party in government but without becoming part of the Ministry itself, would have been called a "confidence and supply agreement"; but this document is presented instead as "an agreement [...] on support for the government in parliament." The wording of the title - "Agreement between the Conservative and Unionist Party and the Democratic Unionist Party on Support for the Government in Parliament" — and the second paragraph allude to the inner workings of the Fixed-Term Parliaments Act. The second paragraph contains the crux of the agreement: 
The DUP agrees to support the Government on all motions of confidence; and on the Queen's Speech; the budget; finance bills; supply and appropriations legislation and Estimates.

Votes on the Address in Reply to the Queen's Speech and on supply bills no longer act as votes of confidence per se. So the Commons could still vote against the Queen's Speech or a budget, but that vote alone would no longer amount to an automatic withdrawal of confidence in the Ministry, and the Ministry would not be absolutely obliged to resign unless it lost a vote on the motion "That this House has no confidence in Her Majesty's Government." Yet, in a practical sense, the Prime Minister might choose to resign anyway, which would only expose the redundancy and stupidity of the Fixed-Term Parliaments Act. This is how the Fixed-Term Parliaments Act has tampered with and ruined the confidence convention and turned something eminently practical - and very British - into something absurd, codified, and officious, in other words, something very European.

While the May government can probably sustain a majority in this new Parliament, the results of this election have nevertheless severely undermined Theresa May's leadership. After all, May had premised this risky early dissolution and general election on the idea that the United Kingdom needed "strong leadership" during the negotiations with Brussels over the precise terms of the United Kingdom's exit from the European Union. She asserted that voters faced a choice between "strong leadership in the national interest" of the Conservatives and "a coalition of chaos." 572 By definition, May's high-risk gamble has failed, because it required a substantial increase in the Conservatives' parliamentary majority, not a small loss or stalemate. Britons now face a coalition of Dry Tories and sectarian Northern Irish Presbyterians. Prime Minister May learned a hard lesson. She proved unworthy of wielding the treacherous power of early dissolution and its alleged advantages to the incumbent government against Labour leader Jeremy Corbyn; the early election instead served its own ends. The Fixed-Term Parliaments Act has become May's Bane.

\section{The Potential Repeal of the Fixed-Term Parliaments Act}

The Conservative Manifesto of 2017 stated simply: "We will repeal the Fixed-term Parliaments Act." ${ }^{, 573}$ While it is unlikely that the May government would be able to carry out this pledge in a minority parliament, sections 7(4)-(6) of the statute already provides for its own review by a parliamentary committee in 2020 :

7 Final Provisions

(4) The Prime Minister must make arrangements-

(a) for a committee to carry out a review of the operation of this Act and, if appropriate in consequence of its findings, to make recommendations for the repeal or amendment of this Act, and (b) for the publication of the committee's findings and recommendations (if any).

(5) A majority of the members of the committee are to be members of the House of Commons.

(6) Arrangements under subsection (4)(a) are to be made no earlier than 1 June 2020 and no later than 30 November 2020 . $^{574}$

Under the old Common Law Abeyance Principle described earlier and demonstrated in the history of English and British parliamentarism, repealing the Fixed-Term Parliaments Act would have restored the British Crown's prerogative authority over dissolution. However, as Robert Craig explains, section 16 of the Interpretation Act, 1978 has put the Abeyance Principle 
itself into abeyance, which means that a "bare repeal" of the Fixed-Term Parliaments Act, 2011 would now not suffice to restore the prerogative status quo ante. ${ }^{575}$ At minimum, the repeal bill would also have to "revive the dissolution prerogative" through express wording. ${ }^{576}$ Logically, the Westminster Parliament would never have enacted this provision in the Interpretation Act unless an older principle prevailed at Common Law that the repeal of a statute would restore any prerogative that it had once displaced. ${ }^{577}$ But this raises an interesting metaphysical paradox about the nature of prerogative authority: if the Westminster Parliament would have to repeal the Fixed-Term Parliaments Act and also restore the prerogative which prevailed from 1661 to 2011 in statute, then this new legislation would provide a statutory basis, however vague, for a prerogative authority - even though prerogative, by definition, remains uncodified. Perhaps such an express revival of prerogative in statute could be viewed merely as referring to the existence of a prerogative authority rather than as codifying it per se.

The Fixed-Term Parliaments Act, 2011 repealed the provisions of the Septennial Act, 1715 and the Parliament Act, 1911 that set the maximum life of a parliament at seven, and subsequently five, years. Craig therefore argues that a bare repeal of the Fixed-Term Parliaments Act would leave these old provisions repealed and thus, in turn, give parliaments an unlimited legal lifespan - rather like the Long Parliament - and also fail to restore the Crown's prerogative authority over dissolution. ${ }^{578}$ In classic British understatement, he describes this scenario as "less than ideal." 579

Given that the Fixed-Term Parliaments Act repealed the Septennial Act, 1715 and that the Parliament Act, 1911 reduced the maximum lifespan of parliaments from seven to five years in wording which ties into the Septennial Act, the simple answer to the Bare Repeal Conundrum lies in passing a new Parliament Act. First, this new legislation would repeal the Fixed-Term Parliaments Act, 2011 outright; second, it would then explicitly restore the Crown's prerogative authority over dissolution through wording similar to the Septennial Act, 1715, such as: "Parliaments shall have Continuance for five Years, unless sooner dissolved by the Queen."580 Alternatively, the British Parliament could use section 50 of the Constitution Act, 1867 and section 4(1) of the Constitution Act, 1982 as inspiration: "Every House of Commons shall continue for five years from the return of writs for choosing the House (subject to be sooner dissolved by the Queen) and no longer."

Craig then over-complicates the former prerogative over dissolution (1661-2011) and claims that any statute repealing the Fixed-Term Parliaments Act should also not restore the former prerogative because it could put Her Majesty the Queen in a politically contentious role, and he cites the King-Byng Thing of 1926 in Canada and The Dismissal of 1975 in Australia; tellingly, he does not cite any British precedents but instead relies upon British hypotheticals and potentialities which have never happened in order to justify his claims. ${ }^{581}$ (The British early dissolution of 1974 is not comparable to the other two cases).

He then suggests that the Westminster Parliament should not seek to revive the former prerogative over dissolution but instead replace the Fixed-Term Parliaments Act with another statutory system even worse and even more convoluted. If Parliament did a bare repeal of the Fixed-Term Parliaments Act without reviving the prerogative, then the United Kingdom would return to a system analogous to the English precedents in the first Triennial Act, 1640 and the 
Long Parliament Act, 1641 where each individual parliament would have to dissolve itself through a statute ending its own life. ${ }^{52}$ This plan would also involve conjuring up a new convention by unilateral declaration that parliament would live no more than five years. Instead, Craig proposes "a better solution" through which Parliament would drive a wedge between the Queen and Prime Minister; it would repeal the Fixed-Term Parliaments Act and replace it with a new system where dissolutions could only occur statutorily and following three steps:

1. First, a simple majority in the House of Commons must support a motion "That this House believes that parliament should be dissolved immediately";

2. Second, the Prime Minister would then advise the Queen to dissolve Parliament; and

3. Third, the Queen would dissolve Parliament on and in accordance with the Prime Minister's advice, without any discretion to refuse dissolution. ${ }^{583}$

This system would therefore impose a distinction between a motion for early dissolution, to which the Prime Minister would, apparently, retain the discretion to ignore because Craig's motion only says that "parliament should be dissolved immediately" but not that it "must" be, and a motion of non-confidence, in response to which a Prime Minister could resign or table a dissolution motion himself. The act would "confer a general statutory power on Prime Ministers" which, in turn, they could "exercise at their discretion to seek a statutory dissolution from a monarch who has no discretion to refuse." ${ }^{, 584}$ Craig likens it to section 45 of the aforementioned Scotland Act, 1998, which establishes a procedure for confirmation votes similar to those used in Continental Europe and identical to that found in the Northwest Territories and Nunavut, where the Queen appoints Scotland's First Minister on and in accordance with the advice of the Scottish Parliament. ${ }^{585}$

Frankly, Craig's proposed new system, which would still formally preserve a role for both the Sovereign's primary constitutional advisor and the Sovereign but sunder the organic link between the two offices which had prevailed under the dissolution prerogative for centuries and replace it with a confusing three-stage statutory system, is the worst alterative - less desirable even than the Fixed-Term Parliaments Act that it would replace. Craig claims that his proposal would update his principles of "non-royal involvement" and "prioritise political flexibility over legal rigidity," Sovereign's prerogative authority over appointing Prime Ministers instead of replacing it with a new procedure on confirmation voting, which violates his first principle of keeping the Sovereign out of politics and harkens back to what he regards as the bad precedent from 1963 where Her Majesty appointed Sir Alec Douglas-Home as Prime Minister at her discretion only because the Conservative Party itself had failed to offer a viable candidate on its own. ${ }^{587}$ The Westminster Parliament, of course, could carry out Craig's idea of severing the link between the Queen and Prime Minister, unlike the Parliament of Canada or provincial legislatures, because it is not limited by a codified constitution. But this system would promote the irresponsibility of ministers of the Crown for what would remain, formally, an act of the Crown and thus contradict the principles of Responsible Government. If the Westminster Parliament does decide to repeal the Fixed-Term Parliaments Act, the best solution would be to restore the former prerogative in the repeal bill and the formerly well-established constitutional roles of the Queen and Prime Minister under Responsible Government. 


\section{XIII: Analysis and Conclusions}

\section{The Provinces Show the Futility of Fixed-Date Election Laws in Canada}

Generally, governments of all parties and ideological dispositions have supported fixeddate election laws. However, in all of these cases except Manitoba and New Brunswick, it was a new government which introduced fixed-date election legislation within the first two years of its first mandate. Ultimately, these parliamentary debates demonstrate that all fixed-date election bills must obtain the support of the government by Third Reading- and preferably, the government would table such bills itself and take full responsibility for them from the outset. The entire concept of fixed-date election laws therefore depends exclusively on the executive, which shows that fixed-date elections do not in principle favour the legislature at the expense of the executive, as their proponents used to claim. They are the kind of bills that would require Royal Consent if they did in fact fetter the Crown's authority over dissolution.

All federal and provincial fixed-date election laws preserve the Governors' authority over dissolution, through either an affirmation clause or a non-derogation clause; they contain slightly different wording but achieve the same outcome. The aforementioned legislatures have passed their fixed-date election legislation within either their Election Acts, Legislative Assembly Acts (or equivalent), or, as in British Columbia, a provincial Constitution Act.

Figure 4: Timeline of Enactment by Legislature

\begin{tabular}{|l|l|l|}
\hline \multicolumn{1}{|c|}{ Jurisdiction } & \multicolumn{1}{c|}{ Year of Enactment (and Amendment) } & \multicolumn{1}{c|}{ Party in Government } \\
\hline British Columbia & $\begin{array}{l}2001 \\
(2017)\end{array}$ & $\begin{array}{l}\text { BC Liberals } \\
\text { (New Democrats) }\end{array}$ \\
\hline \multirow{2}{*}{ Newfoundland \& Labrador } & $\begin{array}{l}\text { (2004 } \\
(2015)\end{array}$ & $\begin{array}{l}\text { Conservatives } \\
\text { (Conservatives) }\end{array}$ \\
\hline \multirow{2}{*}{ Ontario } & $\begin{array}{l}2005 \\
(2016)\end{array}$ & $\begin{array}{l}\text { Liberals } \\
\text { (Liberals) }\end{array}$ \\
\hline Northwest Territories & 2006 & Not applicable \\
\hline New Brunswick & 2007 & Conservatives \\
\hline Canada & 2007 & Conservatives \\
\hline Manitoba & 2008 & $\begin{array}{l}\text { New Democrats } \\
\text { (New Democrats) }\end{array}$ \\
\hline \multirow{2}{*}{ Saskatchewan } & $(2012)$ & $\begin{array}{l}\text { Saskatchewan Party } \\
\text { (Saskatchewan Party) }\end{array}$ \\
\hline Prince Edward Island & 2008 & $\begin{array}{l}\text { Liberals } \\
\text { (Liberals) }\end{array}$ \\
\hline Alberta & $(2012)$ & Conservatives \\
\hline Quebec & 2008 & Pequistes \\
\hline Nunavut & $(2013)$ & Not applicable \\
\hline
\end{tabular}


Figure 5: Form of the Clause Preserving the Governor's Authority

\begin{tabular}{|c|c|}
\hline Non-Derogation Clause & Affirmation Clause \\
\hline Alberta & British Columbia \\
\hline Saskatchewan & Quebec* (But Quebec's affirmative clause is distinct). \\
\hline Manitoba & \\
\hline Ontario & \\
\hline New Brunswick & \\
\hline Prince Edward Island & \\
\hline Newfoundland \& Labrador & \\
\hline Canada & \\
\hline Northwest Territories & \\
\hline Nunavut & \\
\hline
\end{tabular}

Figure 6: Statute Containing the Provisions for Fixed-Date Elections

\begin{tabular}{|l|l|l|}
\hline \multicolumn{1}{|c|}{ Elections Act } & \multicolumn{1}{|c|}{ Legislative Assembly Act } & \multicolumn{1}{c|}{ Constitution Act } \\
\hline Canada & New Brunswick & \multirow{3}{*}{ British Columbia } \\
\hline Alberta & Newfoundland \& Labrador & \\
\cline { 1 - 2 } Manitoba & Saskatchewan & \\
\cline { 1 - 2 } Ontario & Quebec & \\
\cline { 1 - 2 } Quebec & & \\
\cline { 1 - 2 } Prince Edward Island & & \\
\hline
\end{tabular}

Figure 7: Timing of the Next Scheduled Elections

\begin{tabular}{|l|l|}
\hline \multicolumn{1}{|c|}{ Jurisdiction } & \multicolumn{1}{c|}{ Month and Year } \\
\hline Canada & October 2019 \\
\hline British Columbia & October 2021 \\
\hline Alberta & Between March and May 2019 \\
\hline Saskatchewan & November 2020 (for April 2021?) \\
\hline Manitoba & October 2020 \\
\hline Ontario & June 2022 \\
\hline Quebec & September 2022 \\
\hline New Brunswick & September 2022 \\
\hline Prince Edward Island & October 2019 for April 2020 \\
\hline Newfoundland \& Labrador & October 2019 for November 2019 \\
\hline
\end{tabular}

Figure 8: The Trouble with Timing

\begin{tabular}{|l|}
\hline \multicolumn{1}{|c|}{ Legislatures Which Extended Their Lives } \\
\hline Newfoundland \& Labrador, 2015 \\
\hline Manitoba, 2016 \\
\hline Saskatchewan, 2016 \\
\hline British Columbia, 2017 \\
\hline Prince Edward Island, 2020? \\
\hline Saskatchewan, 2021? \\
\hline
\end{tabular}


Under the Thelen-Mahoney model, the Canadian model of fixed-date election laws provides a straightforward example of Layering onto that base: as their non-derogation clauses say, they deliberately did not replace the old system and instead merely added to existing rules. They preserved the authority of the Governor General to dissolve Parliament on the advice of the Prime Minister and of the Lieutenant Governors to dissolve legislatures on the advice of Premiers and the established constitutional positions of the Queen of Canada's representatives and Ministers of the Crown. However, early proponents of fixed-date election laws like Heard and Russell interpreted these conservative laws as radical and sought to present them as a form of Drift. When their first efforts failed, they attempted to force the Canadian fixed-date election laws as a form of Conversion and argued - incorrectly, as the facts and precedents show - that the statute laws had amended constitutional conventions, even though the latter are not justiciable and not codified.

The Canadian fixed-date election laws have become highly reactive and have remained at least one step behind all the relevant developments in a process that I would call - if I can myself layer on the Thelen-Mahoney Model - "compound layering." Each new change brings about a potential complication of its own and creates a potentially infinite series of necessary corrections, one correction begetting another. A quirk of Canadian federalism, with its separate federal and provincial party systems, serves as the primary causes of these woes. These overlapping federal and provincial elections would have created a logistical nightmare because the federal and provincial political parties rely on the same volunteers, even though only the New Democratic Party has integrated all its federal and provincial iterations into one organization. ${ }^{588}$

Prime Minister Harper met bilaterally and separately with Premier Wall of Saskatchewan, Premier Selinger of Manitoba, and Premier Ghiz of Prince Edward Island in 2011, 2012, and 2013; they determined that these provinces would all alter their fixed-date election laws in order to avoid conflict with the federal election. ${ }^{589}$ The impetus of these amendments to the provincial fixed-date election laws of Manitoba, Saskatchewan, and Prince Edward Island appears to have sprung from inter-governmental negotiations between First Ministers, which in turn raises the question as to why Prime Minister Harper and the Premiers should schedule the dates of provincial election in conjunction with one another. Premier Wall even attempted to persuade Prime Minister Harper to change the date of the federal election! ${ }^{590}$ In April 2014, Premier Ghiz reported to the assembly that Prime Minister Harper had told him in 2012 that he intended to alter the date of the next federal general election so that it did not overlap with all the provincial general elections that will take place in the fall of 2015, but that Harper had abandoned this idea in late 2011 after Ontarians elected a minority parliament. ${ }^{591}$ Those who promoted the fixed-date election laws as more democratic should baulk at the very undemocratic inter-governmental negotiation and executive federalism that directly resulted in the amendments to the fixed-date election laws of the three provinces. ${ }^{592}$

But the catalyst which exposed this fundamental flaw began in earnest as a consequence of the early federal election of May 2011, which the Canada Elections Act had originally scheduled for October 2012. The vote of non-confidence on which the Harper government fell in March 2011 had thus altered the timing of the next federal general election and placed it in October 2015, the same timeframe of the next scheduled general elections of five of the ten provinces. This was partially mitigated by Premier Wynne's early dissolution in Ontario in June 
2014, but that left Manitoba, Saskatchewan, Prince Edward Island, and Newfoundland and Labrador with scheduled provincial elections that would have overlapped with the federal writ. Manitoba led the way in 2012. Its legislature passed a Postponement Amendment, whereby the province would delay its scheduled provincial election by six months, from October until the following April, if it would have otherwise overlapped with a scheduled federal election. Saskatchewan and Prince Edward Island followed suit with almost identical legislation in 2013, though Prince Edward Island did not invoke it in the fall of 2015 because Premier MacLauchlan opted for early dissolution in the spring of 2015.

And the potential for compounded layering does not end there. Premier MacLauchlan's early dissolution in the spring of 2015 happened too early to alter Prince Edward Island's electoral calendar, which means that its scheduled election in the fall of 2019 will also overlap with the next scheduled federal election. This, in turn, would push the province's election to April 2020 - unless, of course, MacLauchlan goes early again. And because of the postponement of its previous election, Saskatchewan's next provincial election scheduled for November 2020 would overlap with scheduled municipal elections. Since Saskatchewan's fixed-date election law only allows the provincial election to be postponed if it would coincide with a federal election, this means that the legislature would have to amend the statute scheduling provincial elections or municipal elections, or allow the overlap to take place, or that Premier Moe would simply have to pursue an early dissolution.

In 2015, Newfoundland \& Labrador opted to delay its scheduled provincial election by only one month instead of five or six, from October to November. In 2017, British Columbia elected to do the opposite of Ontario and move its scheduled elections from May to October. In so doing, it built upon the precedents of Manitoba, Saskatchewan, Prince Edward Island, and Newfoundland and Labrador by doubling up the Postponement Clause and avoiding Saskatchewan's current predicament: the provincial election can be delayed if it would overlap with either the scheduled federal elections or scheduled municipal elections. Furthermore, this provision does not set a specific alterative date but instead allows the Premier to choose it in consultation with the Chief Electoral Officer of the province and the leaders of all recognized parties in the legislative assembly.

Finally, the Trudeau government recently introduced another form of compound layering as a direct response to the problems that the fixed-date election of October 2015 caused: long, increasingly structured pre-writ campaigning, as well as a long official writ. The Trudeau government's bill would therefore create and recognize an official pre-writ period encompassing the June and July in the year of a scheduled election and impose a maximum duration of 50 days to accompany the minimum of 36 days. In a venerable mark of distinction, Quebec got its fixeddate election law right the first time; by allowing its provincial general elections to be delayed if they would coincide with either scheduled federal or municipal elections, Quebec avoided the quagmire of compound layering that the other provinces had to muddle through.

The provincial fixed-date election laws rely on the maximum life of a provincial legislature as per the Constitution Act, 1982. Most of the laws shorten the maximum life of the legislature from five years to four years; however, the amended laws in Manitoba, Saskatchewan, and Prince Edward Island, Ontario, and British Columbia, along with Quebec's original law, 
have set a standard maximum of four years but a condition maximum of four and one-half years in the event that the provincial and federal general elections would otherwise have inconveniently overlapped with one another. These ad hoc amendments respond to one specific situation and have exposed the fundamental flaws in so-called "fixed-date elections:" they are "fixed" until the Premier says otherwise by advising an early dissolution, or until the assembly says otherwise by amending the statute.

\section{Snap Elections and When Early Dissolution is Just}

Based on the political usage of this term, a "snap election" occurs when a First Minister advises dissolution prior to the customary quadrennial interval and while his government still commands the confidence of the assembly. This definition therefore excludes the early dissolutions of 1926, 1963, 1974, 1979, 2005, and 2011, which came about because the House of Commons withdrew its confidence from the government. The Federal Court also endorsed this definition. ${ }^{593}$ However, a "snap election" could conceivably include another category, where a First Minister appointed mid-parliament wants to "seek a mandate" from the electorate and advises the dissolution of the parliament before the customary quadrennial interval. The first category would include the federal elections of 1911, 1958, 1965, 1974, 1997, 2000, and 2008, and the second category would include the federal elections of 1874, 1968, and 2004. But even these cases present considerable variation and ultimately illustrate that flexible dissolutions have served Canada well. Aside from snap elections, a First Minister leading a single-party minority government could also deliberately engineer the defeat of his own government by tabling legislation that the Opposition could not possibly support. The Assembly would then withdraw its confidence from the Government, thus precluding the executive initiative necessary for a true "snap election", but some observers would still regard such a course as "breaking the spirit" of the fixed-date elections law. The federal general elections of 1974 and 2011 could fall under this category.

In November 1873, Prime Minister Alexander Mackenzie had formed a Liberal ministry mid-parliament after Sir John A. Macdonald resigned the premiership amidst the Pacific Scandal. Prime Minister Mackenzie advised an early dissolution of this parliament in January 1874 (after it was elected in 1872), and the Liberals secured a fresh parliamentary majority and a mandate to vanquish the corruption of the Macdonald Ministry. In 1911, Prime Minister Sir Wilfrid Laurier advised an early dissolution in order to obtain a new mandate from the electorate on Reciprocity with the United States. Sir Robert Borden's Conservatives trounced the Liberals and secured a parliamentary majority.

In 1957, Prime Minister Diefenbaker came to office and led a single-party minority government. Prime Minister Louis St. Laurent had chosen to resign after the election rather than meeting the new Parliament and testing its confidence, and perhaps forming an alliance or formal coalition with the Cooperative Commonwealth Federation (the predecessor of the New Democratic Party) in order to overcome the Progressive Conservative plurality. An incumbent Prime Minister and Government may exercise this constitutionally legitimate option of testing the confidence of the Commons, rather than announcing their intention to resign, when they face a minority parliament because of the general principle that the Queen must never be left without a government. ${ }^{594}$ At the federal level thus far, only Prime Minister King exercised this right 
when his party did not win the plurality of seats, in $1925 .^{595}$ Premier Christie Clark of British Columbia pursued this option in 2017, as did Premier Frank Millar of Ontario in 1985. In both cases, these incumbent governments, reduced to mere single-party pluralities, lost their first votes on confidence on the Address in Reply to the Speech from the Throne; both Premiers also brazenly advised early dissolution, which the Lieutenant Governors refused, and thus both Premiers were forced to resign. These abrupt falls from grace perhaps explains why most Canadian First Ministers do not bother banking on this risky strategy and instead choose to resign if their parties go from majority to plurality.

In 1958, Diefenbaker advised an early dissolution after Liberal leader Lester Pearson had suggested that Diefenbaker should resign as Prime Minister and "let the Liberals resume their rightful place" as the natural governing party. ${ }^{596}$ This case also demonstrates the pattern where the Opposition wants an election and the Government might not want one. Diefenbaker's Conservatives won a massive parliamentary majority. In the general election of 1962 , Diefenbaker's Conservatives lost their majority but retained a plurality. In the general election of 1963, the Liberals won the plurality of seats; while Diefenbaker mused about staying on and meeting the new Commons, he ultimately resigned just as St. Laurent did in 1957. ${ }^{597}$

In 1965, Lester Pearson sought to increase his Liberal plurality and minority government to a parliamentary majority. However, the election of 1965 produced a similar result to the election of 1963, and Pearson's Liberals merely maintained their parliamentary plurality. Pearson stepped down from the Liberal leadership and resigned the Premiership in 1968. The Governor General then appointed Pierre Trudeau as Prime Minister on 20 April 1968, and he advised dissolution on 23 April 1968 in order to seek a new mandate for his "Just Society."

In 1997, Prime Minister Jean Chretien advised an early dissolution, ostensibly in order to seek a new mandate on what the government should do after having eliminated the deficit and how it should deal with the upcoming surplus. The Liberals retained their parliamentary majority, though by a slim margin. Curiously, Prime Minister Chretien may have inadvertently taken a plank from the Reform Party's platform of 1993, which stated that the Government of Canada should "balance the budget in each three-year period or to be obliged to call an election on the issue." ${ }^{, 598}$ On 22 October 2000, Prime Minister Chretien advised another early dissolution after weeks of speculation; Hansard clearly shows that as early as 25 September 2000, MPs of all parties either welcomed or accepted the "coming election." ${ }^{, 599}$ Stockwell Day, the Leader of the Opposition and Canadian Alliance, even dared Prime Minister Chretien to advise an early dissolution and lent new credibility to the cliché that one should be careful what one wishes for. $^{600}$

Mr. Stockwell Day (Leader of the Opposition, Canadian Alliance): Will the Prime Minister, who disagrees with his finance minister on the high marginal rates of taxes and who now disagrees with his MPs, do one of two things? Will he either resign because he has no support over there or call an election based on his record of being the highest taxing leader in the G-7 countries?

Right Hon. Jean Chretien (Prime Minister, Lib.): Mr. Speaker, two weeks ago he was for an early election. Over the weekend he was not for an early election. Now he is for an early election again. This gentleman flip-flops so much that we are having fun on this side. 
On 19 October 2000, Prime Minister Chretien confirmed before the Commons that he would advise an early dissolution, declaring: "We are going into an election," ostensibly in order to obtain another mandate on how to spend the new surplus, whether on tax cuts, paying down the debt, or spending more on social programs. ${ }^{601}$ Chretien implies this motivation in the same statement where he declared that he would seek an early dissolution:

\begin{abstract}
Right Hon. Jean Chretien (Prime Minister, Lib.): Mr. Speaker, when we returned in September the first question raised in the House was about having a mini-budget. They wanted the Minister of Finance to say what he would do with the great results he was having in terms of surpluses and so on. We obliged. We told the Canadian people that because of the good management we have provided to the country over the last seven years there was some money available. We were delighted to return some of it in the form of tax reductions and at the same time investments in education, research, Medicare, and so on. I am sure the people of Canada will recognize that they have been extremely well served in the last seven years.
\end{abstract}

Chretien was right, and the Liberals increased their parliamentary majority in the 2000 election. Within the life of the $37^{\text {th }}$ Parliament, Chretien announced his intention to resign, and the Liberal Party elected Paul Martin as its new leader. The Governor General invited Paul Martin to form a government on 12 December 2003, and he advised dissolution on 23 May 2004. The Liberals lost their parliamentary majority, but retained a plurality; Martin continued to lead a single-party minority government for the life of the $38^{\text {th }}$ Parliament (2004-2005).

In 2008, Prime Minister Harper advised an early dissolution of the $39^{\text {th }}$ Parliament because he judged, after meeting with two of the three other party leaders, that his single-party minority government would soon lose control of the parliamentary agenda and thus the confidence of the Commons. This is most similar to Diefenbaker's early dissolution in 1958 and Pearson's in 1963. Harper also sought an elusive parliamentary majority after the $39^{\text {th }}$ Parliament had survived as the longest continuous minority parliament up to that point in Canadian history. Instead, the Conservatives retained their parliamentary plurality, though they did increase their number and share of seats in the $40^{\text {th }}$ Parliament.

Adam Dodek, Professor of Constitutional Law at the University of Ottawa, points out that dissolution is unique among the Crown's authorities because the electorate can hold the Prime Minister to account, "directly and immediately," for this particular exercise of judgement, unlike, say, for appointments, deployment of troops, negotiation of treaties, or cabinet shuffles. ${ }^{602}$ This applies especially perhaps to early dissolution.

Of these nine "snap elections" since Confederation, five undoubtedly favoured the Government, which either retained or increased its majority $(1874,1958,1968,1997$, and 2000). In two, minority governments succeeded only in retaining their parliamentary plurality (1965 and 2008) when Pearson and Harper sought parliamentary majorities. In 1911, Laurier's Liberals suffered a crushing defeat. The election of 2004 reduced Martin's Liberals from a parliamentary majority to a plurality. Five of these "snap elections" (those of 1874, 1911, 1997, 2000, and 2004) involved the early dissolution of majority parliaments that supported single-party majority governments; therefore, no possible alternative governments existed within those parliaments, and under those conditions the Governor General had no choice but to dissolve in accordance with Prime Ministerial advice. In the minority parliaments of 1958, 1963, 1965, the Opposition 
parties demonstrated by their own statements that they preferred an early election instead of attempting to form government themselves within the existing parliament.

Figure 9: How Federal Snap Elections Affected the Incumbent Government

\begin{tabular}{|l|l|}
\hline \multicolumn{1}{|c|}{ Snap Elections } & \multicolumn{1}{c|}{ How They Affected the Incumbent } \\
\hline 1874 & Win: The Liberals expanded their parliamentary majority \\
\hline 1911 & Loss: Laurier ended 15 years of Liberal government \\
\hline 1958 & Win: Conservatives went from plurality to majority \\
\hline 1965 & Draw: Liberals went from plurality to plurality \\
\hline 1968 & Win: Liberals went from plurality to majority \\
\hline 1997 & Win: Liberals went from majority to majority \\
\hline 2000 & Win: Liberals went from majority to majority \\
\hline 2004 & Loss: Liberals went from majority to plurality \\
\hline 2008 & Draw: Conservatives went from plurality to plurality \\
\hline
\end{tabular}

That comes to 5 wins, 2 loses, and 2 draws. The incumbent federal government came out ahead most of the time, though success is still not guaranteed.

Alpheus Todd outlined four situations where the Prime Minister could, and even should, advise a dissolution of parliament and "an appeal to the constituent body" - the Canadian people. ${ }^{603}$ First, an early dissolution could take place in order to validate the Sovereign's dismissal of one Ministry and appointment of another, as George III did in 1783 and 1807, and as William IV did in $1834 .{ }^{604}$ A modified version of this category applies in Canada, where Governors have rarely actively dismissed Ministries since the grant of Responsible Government, with the exceptions in New Brunswick in 1855 and 1866, where the Governor insisted upon early dissolutions against the advice of his ministers, thus forcing them to resign ${ }^{605}$ and Quebec in 1878 and 1891, where the Lieutenant-Governor outright dismissed his ministers. ${ }^{606}$ Instead, Governors usually dismiss, or force the resignations of, First Ministers by refusing to implement their constitutional advice.

Such instances occurred in 1896, when the Earl of Aberdeen refused to promulgate Sir Charles Tupper's advice to summon several Senators and appoint several judges during the caretaker period and in 1926 when Lord Byng refused to dissolve Parliament upon Prime Minister King's advice. ${ }^{607}$ In 1900, Prime Minister Sir Wilfrid Laurier threatened to resign if Lord Minto refused to accept his government's constitutional advice to dismiss General Hutton as the General Officer Commanding Her Majesty's troops in British North America; Minto ultimately acquiesced. ${ }^{608}$ Second, an early dissolution could break the deadlock between the two Houses of Parliament. Third, the First Minister could seek an early dissolution due to "some question of public policy upon which ministers of the Crown and the House of Commons are at issue" or to obtain a mandate from the electorate, and thus validate the Governor's confidence in him as his First Minister of the Crown and principle constitutional advisor. ${ }^{609}$ Fourth, an early dissolution should occur if "the House of Commons does not correctly represent the opinions and wishes of the nation."

Canadian constitutional historian D. Michael Jackson has argued that the Prime Minister can advise dissolution - or at least threaten it - in order to deal with a split in the Cabinet, ${ }^{611}$ as Premier Romanow of Saskatchewan considered, but did not undertake, in $1994 .{ }^{612}$ British 
constitutional historian Vernon Bogdanor has also argued that "there are a number of respectable reasons for an early dissolution" ${ }^{, 13}$ and lists four such scenarios: first, when a Prime Minister appointed mid-parliament "seeks a personal mandate" from the electorate; second, when a Prime Minister, irrespective of when he was appointed, "seek[s] a mandate for a new policy"; third, when the current parliament has become deadlocked and cannot support any viable government; and fourth, when the Prime Minister wants the electorate "to validate a change of coalition partners." 614

Todd's fourth category would imply that both the Government and any potential alternative government within the existing assembly would be at variance with the opinions and wishes of the electorate. The Canadian federal elections of 1911 and 1988 certainly fall under Todd's third category, and the election of 1988 probably also falls under Todd's second category, because the Liberals used their majority in the Senate to block the Conservative Mulroney government's free-trade implementation bill. Todd adds that the Prime Minister should only advise an early dissolution if "he has a reasonable prospect" of winning a parliamentary majority in the general election. ${ }^{615}$ In 1997 and 2000, Prime Minister Chretien believed that his appeal to the constituent body of the body politic of the Realm would sustain his government - and he was correct on both occasions. Shortly after advising and receiving early dissolution on 22 October 2000, Chretien emerged from Rideau Hall and said to the press: "It's very important for Canadians, in my judgement, that we [the Liberals] win. You know, I'm not going to go to the people and say to them, I'd like somebody else to win. So of course, I'm calling an election to win." ${ }^{, 616}$ And he did indeed lead the Liberals to an increased parliamentary majority.

Chretien also sought new mandates in both 1997 and 2000 on the question of Canada's public finances and how the Government should deal with budgetary deficits and surpluses, which would fall under Todd's third category. There are various legitimate reasons to allow for early dissolution. Bogdanor's fourth category could have applied in Canada in 2008 to the $40^{\text {th }}$ Parliament. Bogdanor argues that it would be not be in accord with "democratic principles" if the parties "form a coalition after an election which the voters had no chance to endorse" or if the government "swaps coalition partners in the middle of a parliament without securing popular endorsement for this change." ${ }^{617}$ Bogdanor concludes that in a multi-party system, dissolution can act as "an essential weapon for voters," who could wield it "to prevent inter-party manoeuvring and coalition deals organised behind closed doors after the votes have been counted." ${ }^{\prime 618}$ Todd's third category and Bogdanor's first category, that a First Minister appointed mid-parliament may endeavour to seek his own mandate from the electorate, corresponds in principle to the defunct practice of ministerial by-elections, where previously in both Canada and the United Kingdom, any MP appointed to the Privy Council had to resign his seat and seek reelection in a by-election. ${ }^{619}$

\section{The Failure of the Canadian Fixed-Date Election Laws}

The Canadian model of fixed-date elections makes no difference in a majority parliament, where no alternative government could possibly be formed. The Governor General could only enforce a contrived constitutional convention and reject a Prime Minister's advice to dissolve, thereby forcing his resignation, and appoint a new Prime Minister to take responsibility 
for the resignation of his predecessor in a minority parliament that could in turn sustain a new alternative government. If the Governor General ever attempted to dismiss a Prime Minister whose single-party majority government commanded the confidence of the Commons, Canada would be left without a functioning government, and the Governor General thus would have violated his primary constitutional duty - to ensure that there is always a duly constituted Ministry in office. ${ }^{620}$ In so doing, the Governor General would also precipitate a constitutional crisis and provoke the Prime Minister to advise the Queen to dismiss him.

Consequently, John Pepall has argued that fixed-date elections "solve a problem that does not exist." ${ }^{21}$ Given that Chretien's Liberals faced a right-wing divided between two political parties hostile to one another in 1997 and 2000, as Pepall points out, if he had waited an additional six to twelve months in either case, the Liberals would probably have retained their parliamentary majorities, or at the very least would have formed strong pluralities. ${ }^{622}$ Bogdanor has made the same argument in the British context and noted that, in particular, Thatcher's Conservatives and Blair's Labourites would have won elections whether they went to the country after four years or five years. ${ }^{623}$

Much to their consternation, fixed-date elections would not have helped the right-wing parties form government in Canada in the 1990s; only "uniting the right" into one political national party could and did achieve that goal. As the Government argued in the Conacher cases, "a Prime Minister's power to request a dissolution of Parliament and the timing of an election does not invariably confer an electoral advantage on the governing party."624 The aforesaid analysis of "snap elections" in Canada since 1867 validates the Government of Canada's arguments. In addition, the minimum length of a federal general election of 36 days provides sufficient time in which the various parties can present their candidates and platforms and in which voters may decide how to cast their ballots. ${ }^{625}$ In short, electoral campaigns matter; the governing party's victory is not guaranteed at the end of the writ simply because the public opinion polls favour the government before the writ is drawn up.

Pepall highlights the absurdity of the Harper government's position in 2007 that the date of the election is "fixed" unless the Opposition withdrew its confidence from the Government because this formulation could just as easily have described the Canadian system prior to the enactment of fixed-date election laws. In addition, the Canadian model of fixed-date elections would merely transfer the control of an early dissolution from the Government to the Opposition; it therefore does not, in principle or in fact, create true fixed-term parliaments. ${ }^{626}$ If the Opposition can precipitate an early election, then the Government should be able to do the same.

Proponents of the Canadian model of fixed-date election laws argued that they would ensure "fairness, transparency and predictability, improved governance, and increased voter turnout." 627 While the first three are more difficult to quantify, as of 2018, there is absolutely no doubt that fixed-date election laws have utterly failed to arrest the decline of voter turnout in any province or at the federal level. ${ }^{628}$ Peter Russell argued that fixed-date elections would "decrease the possibility of snap elections," which in turn "should also make both the government and opposition more careful about the votes they treat as confidence matters." ${ }^{29}$ Russell also predicted that the fixed-date elections would "lead to a relaxation of strict party discipline." 
The exact opposite trend emerged in practice: the exigencies of a minority parliament required an entrenchment of party discipline as the Government deemed its policy bills, which flow from the Speech from the Throne, matters of confidence. Russell concluded that fixed-date election laws "extend the norm" of quadrennial parliaments to minority parliaments because "the government and opposition parties will be under pressure to work out legislative strategies that will enable Parliament to get some substantial work done without being constantly on the brink of dissolution." ${ }^{, 630}$ Russell also presumes that voters would necessarily punish the parties in Government and Opposition for precipitating an early election. ${ }^{631}$ However, the historical record shows mixed results; voters rewarded Prime Minister Harper in 2008, Premier Wynne in 2014, and Premier MacLauchlan in 2015 but punished Premier Marois in 2014 and Premier Prentice in 2015.

The proponents of fixed-date election laws in Canada used to argue that they would impose certainty in the timing of general elections and ensure that parliaments lasted a regular four years. ${ }^{632}$ In principle, this argument flowed from a fundamental misreading of how our system of government works, and, in practice, precedents have disproven it time and again. The various federal and provincial fixed-date election laws failed to achieve that objective because they all deliberately preserved the authority of the Governor General and Lieutenant Governors to dissolve the House of Commons and legislative assemblies, thereby also preserving the established constitutional positions of the governors and the First Ministers, including the authority of the First Ministers to advise snap elections. Since 2008, five First Ministers have advised early dissolutions without first having lost the confidence of the assembly: Prime Minister Stephen Harper in 2008, Premier Pauline Marois of Quebec in 2013, Premier Kathleen Wynne of Ontario in 2014, Premier Jim Prentice of Alberta in 2015, and Premier Wade MacLauchlan of Prince Edward Island in 2015. Even Andrew Heard would therefore have to grudgingly accept that this practice has become a convention. ${ }^{633}$

Figure 10: The Consequences of Snap Elections Under Fixed-Term Election Laws

\begin{tabular}{|l|l|}
\hline \multicolumn{1}{|c|}{ First Ministers Who Elected to Go Early } & \multicolumn{1}{c|}{ Result for the Incumbent Government } \\
\hline Harper (Canada), 2008 (Minority Parliament) & $\begin{array}{l}\text { Draw: (Conservatives expanded their plurality but failed to } \\
\text { secure a majority) }\end{array}$ \\
\hline Marois (Quebec), 2014 (Minority Parliament) & $\begin{array}{l}\text { Loss: (The incumbent PQ lost and the rival Liberals won a } \\
\text { majority) }\end{array}$ \\
\hline Wynne (Ontario), 2014 (Minority Parliament) & $\begin{array}{l}\text { Win: (The incumbent Liberals went from a plurality to a } \\
\text { majority) }\end{array}$ \\
\hline Prentice (Alberta), 2015 (Majority Parliament) & Loss: (The rival New Democrats won a majority) \\
\hline MacLauchlan (PEI), 2015 (Majority Parliament) & Win (The Liberals expanded their majority) \\
\hline
\end{tabular}

In reality, a fixed-date election law did not alter the adversarial system where the Government and Opposition oppose one another within the House of Commons. As Pepall points out, the Opposition's duty and responsibility is not to be "constructive", but rather to oppose the Government within the Commons and replace the Government following an election. ${ }^{634}$ Only the imposition of constructive non-confidence could force the Opposition and Government to act constructively. The Library of Parliament touted the fixed-date election law in a similar manner to Russell and argued that it would "remove an element of unpredictability from Canada's 
political system, and provide a degree of security of tenure for the House of Commons and the government" and that "opposition parties, knowing that the government has a fixed term of office, might be more constructive in their criticism.",635

The Opposition does not need to abide by constructive non-confidence and only withdraw its confidence from the Government in a minority parliament if it wants to assume office without an election; in most cases, the Opposition would prefer to force an early election and win enough seats to form Government. I have highlighted several examples of this phenomenon in previous sections. Ultimately, they reveal the false premise on which Russell and others based their claim: that the self-interested Government seeks to entrench its hold on power and that the altruistic Opposition holds the public interest at heart. This is manifestly false; the Government wants to remain the Government, and the Opposition seeks to become the Government.

\section{Fixed-Date Election Laws Set A New Baseline for Dissolution by Efflux of Time}

Fixed-date election laws therefore do not - either in principle or in practice - prevent First Ministers from calling early elections because they do not impose a minimum lifespan of a parliament or legislature. However, one of the few concrete effects of these laws is that they do reduce the maximum lifespan of a parliament or legislature from five years to something between four and five years. ${ }^{636}$ These statutes have thus become the new points of reference for the automatic dissolution of a parliament or legislature once it reaches its maximum life.

Section 50 of the Constitution Act, 1867 set the maximum lifespan of the Parliament of Canada at five years:

Every House of Commons shall continue for Five Years from the Day of Return of the Writs for choosing the House (subject to be sooner dissolved by the Governor General), and no longer.

Section 4(1) of the Constitution Act, 1982 reaffirms the aforesaid section 50 and applies the same five-year maximum lifespan to the provincial legislative assemblies:

No House of Commons and no legislative assembly shall continue for longer than five years from the date fixed for the return of the writs at a general election of its members.

Section 56.1 of the Canada Elections Act contains the federal fixed-date elections law:

56.1 (1) Nothing in this section affects the powers of the Governor General, including the power to dissolve Parliament at the Governor General's discretion.

(2) Subject to subsection (1), each general election must be held on the third Monday of October in the fourth calendar year following polling day for the last general election, with the first general election after this section comes into force being held on Monday, October 19, 2009.

This is because statute law can exceed the minimum standards that the Constitution Acts set as supreme law; in this case, the minimum threshold is a maximum lifespan, and the fixeddate election statutes lower the maximum life of the parliament. In contrast, increasing the maximum life of the parliament would require a constitutional amendment to section 50 of the Constitution Act, 1867 . The new maximum life of a parliament cannot be defined precisely as four years, but rather only on a range of four to five years, because the fixed-date election 
provision of the Canada Elections Act mandates that the election occur every fourth October, and not precisely every four years down to the month of the previous writs of election. For instance, the $41^{\text {st }}$ Parliament lived from May 2011 to August 2015. But if the fixed-date election law did set the date of the next election precisely four years after the writs for the previous general election, then the $42^{\text {nd }}$ general federal election would, by necessity, have occurred in May 2015 instead of in October 2015.

The next possible dissolution of the Parliament of Canada by efflux of time could occur in 2019. For instance, if Prime Minister Trudeau forgot to advise the Governor General to dissolve the $42^{\text {nd }}$ Parliament with respect to the election currently scheduled for 21 October 2019, then, under the current statute, the $42^{\text {nd }}$ Parliament would dissolve by efflux of time on Sunday, 19 September 2019 so that the writ would last for the minimum 36 days. Cabinet would then have to remind him that they must present an Order-in-Council to the Governor General, who would then issue a proclamation on their advice promulgating the writs of election. (At this stage, Cabinet would no longer be able to choose a longer writ!) The Prime Minister would then have to advise the Governor General to summon the $43^{\text {rd }}$ Parliament pro forma on a date of his choice.

No First Minister has over attempted to advise a late dissolution relative to a fixed-date election law on the authority of the Constitution Acts, though we have of course seen five instances where the First Minister has advised an early dissolution relative to the next general election scheduled by fixed-date election laws.

\section{Fixed-Date Elections and the Transformation of Westminster Parliamentarism}

Ultimately, the debate on fixed-date elections derives from a more fundamental debate over interpretations of Responsible Government itself and the constitutional position of the Prime Minister within that system. It also relates to two "competing conceptions of the state: mechanistic and organic." ${ }^{\text {, }} 37$ Under the $18^{\text {th }}$-century Balanced Constitution in the United Kingdom, the King and Commons formed an inter-institutional opposition between Crown and Parliament and stricter separation of powers from which the American system of government developed. Responsible Government, which emerged in the United Kingdom after the Reform Act of 1832 and which the Colonial Office in turn granted to British North America in 1848, converted that inter-institutional opposition and wide separation of executive and legislative powers into an intra-institutional opposition between the Government and Opposition, both within the House of Commons, and made the executive subject to the confidence of the legislature. The Government and Opposition both reside within the Commons, and Her Majesty's Loyal Opposition aims to become Her Majesty's Government. This entails a narrow separation of powers. However, the Fixed-Term Parliaments Act, 2011 harkens back to the Balanced Constitution, by putting the Crown's authority over dissolution into abeyance, and reasserts a variant of the $18^{\text {th }}$-century constitution on contemporary Westminster parliamentarism.

Under Responsible Government, the Opposition and the Commons should not seek to reduce the executive authority of the Government; instead, the Opposition should aim to replace the Government so that it could then use the executive authority of the Crown and introduce and enact the policies that it believes would best serve the public interest. Even in a series of three 
consecutive minority parliaments in Canada between 2004 and 2011, the Opposition never made any serious attempts to regulate or limit the authority of the Crown on dissolution when they could plausibly have done so. ${ }^{638}$ Even though any bill that purports to regulate a constitutionally entrenched authority of the Crown would require Royal Consent, which the Governor General gives on and in accordance with the advice of the Prime Minister by Third Reading, the Opposition could have attempted to negotiate and leverage their support for a budget or a major government bill in exchange for Royal Consent to a private member's bill regulating the summoning, prorogation, or dissolution of parliament.

Instead, rather than limiting the executive authority of the Government, the Liberals and New Democrats sought to form Government, and thus exercise that executive authority themselves. The Fixed-term Parliaments Act, 2011 and like-minded reform proposals in Canada stem from the presumption that executive discretion is inherently bad and that restricting the executive's discretionary authority is therefore inherently good and "democratic." But as Alan Hamlin, Professor of Political Theory at the University of Manchester, points out, "While it may be that restricting the discretionary power of the government has appeal in at least some cases, it can be no guarantee of better government [...]." ${ }^{\circ 39}$ If anything, the opposite is true. The traditional Westminster and Canadian system, in which the incumbent First Minister can wield the threat of dissolution over the head of the opposition like the Sword of Damocles, forces the opposition to improve its effectiveness continuously and always present itself as the alternative government - which benefits Westminster parliamentarism overall. ${ }^{640}$

The current Canadian model of fixed-date elections, which attempted - and failed - to create a contrived constitutional convention ex nihilo as a means of by-passing the written constitution, never even occurred to Eugene Forsey and Graham C. Eglington in 1985. In their study on The Question of Confidence in Responsible Government, they argued, correctly, that fixed-term parliaments would necessitate "abolishing the power of the Crown to dissolve Parliament, either in all circumstances or except in limited circumstances" and therefore a constitutional amendment under section 41(a) of the Constitution Act, 1982, because the Crown's authority over dissolution forms part of the "office of the Governor General." ${ }^{, 641}$ Forsey and Eglington also portrayed the proponents of fixed-term parliaments as usurpers of the confidence convention who "see the periodic elections to the House of Commons through popular eyes as "the election of a government.", 642 They also argued that fixed-term parliaments would threaten the independence of the Member of the Parliament, rob him of his authority to force the Government to face the electorate, and "place the House more and more under the yoke of executive domination." 643

They further noted that constructive non-confidence would involve a constitutional amendment under section 41(a) of the Constitution Act, 1982 and would "require the complete codification of rules governing a change in government" and put the Governor General in the position of exercising a greater "deliberative judgement" and discretion on evaluating whether his Prime Minister had lost the confidence of the Commons and whether he should grant him an early dissolution or dismiss him from office. ${ }^{644}$ Fixed-term parliaments and constructive nonconfidence would alter the balance of the constitution and limit the power of individual MPs by forcing them either to support the current Ministry or an alternative Ministry. ${ }^{645}$ For instance, the British Fixed-Term Elections Act provides that fully two-thirds of MPs must support a motion for 
an early dissolution, where before a simple majority of MPs could force the Government to face the electorate. Forsey and Eglington concluded:

the necessary right of the Crown to dissolve the Legislature bear[s] witness to that responsibility of the Executive to the people and its right in proper circumstances to appeal to the people against an unworkable Legislature, an appeal which in the modern world alone affords to our system of government its acceptance by the governed, an acceptance without which it cannot survive. ${ }^{646}$

This covers the history, supposed intent, and concrete effects of Canada's fixed-date election laws. But, ultimately, this project of political reform flows from a simple fear of executive authority as well as a radical desire to uproot centuries of organic growth of the conventional constitution and parliamentary government and to replace it with a rationalized, mechanical artifice. While Responsible Government works in practice, it has committed the grave offence of not working in theory. And modish academics worth their salt cannot let such an affront to rationalism continue to exist.

That "the Prime Minister has too much power" has become an article of faith amongst political activists and a truism amongst university undergraduates - especially when they disagree with the policies of the incumbent Prime Minister. Proponents of fixed-term parliaments also tend believe that the Prime Minister wields a prodigious, undemocratic amount of power and regard fixed-term parliaments as a remedy.

No authors advanced this viewpoint more vociferously than Aucoin, Jarvis, and Turnbull in Democratizing the Constitution: Reforming Responsible Government. They frequently invoke the phrase, "The logic of responsible government" throughout the book and couch their arguments and proposals for reform as fulfilling "the logic of responsible government." They see "the logic of responsible government" as an ideal which our political institutions never managed to attain, as if it were an incomplete or unfinished revolution from the emergence of Responsible Government in the 1840s. They see the Prime Minister's exercise of executive authority as the single greatest impediment to achieving that ideal. For instance, they assert that "The reality of the prerogative powers reverses and perverts the logic of responsible, which dictates that the House of Commons is supreme." "647 The idea that "the reality" of the Crown's executive authority forms an integral part of Responsible Government never occurred to them.

They further believe that "the logic of responsible government" leads inexorably to Continental European-style parliamentarism: codified constitutions, fixed-term parliaments, confirmation voting, and constructive non-confidence. They argue:

The logic of responsible government holds that the people's elected representatives in the

House, rather than the Governor General or the Prime Minister, determine:

- who should form the government after a general election;

- when the government has lost the confidence of the House; and,

- whether there should be a change of government without an election after the government has lost confidence or whether an election should be held. ${ }^{648}$

They have got it all backwards. What they lament as executive domination and an aberration which deviates from the ideal type is, in fact, a key and necessary feature of Responsible Government. They make the same mistake as Peter Russell, who insists that "Prime 
Ministers must not become kings!"649 In fact, Canadian Prime Ministers have always centralized executive authority, as Canadian political scientist Patrice Dutil has demonstrated in his new book, Prime Ministerial Power in Canada: Its Origins Under Macdonald, Laurier, and Borden. ${ }^{650}$

Canadian Prime Ministers have formally centralized cabinet authority in themselves since at least 1896 - and even then, by building upon and codifying what Sir John A. Macdonald had already pioneered informally. Tupper and Laurier in 1896, Borden in 1911, Meighen in 1920, Bennett in 1930, and King in 1935 all issued virtually identical Orders-in-Council outlining the "Special Prerogatives of the Prime Minister." 651 The Prime Minister claimed the authority to nominate persons for several key offices unilaterally, including those of the Governor General and Lieutenant Governors. He also claimed the unilateral authority to advise the Governor General on summoning, proroguing, and dissolving Parliament. Furthermore, these Memorandums on the Special Prerogatives of the Prime Minister also defined and reaffirmed the quorum for Cabinet as the operative part of the Privy Council as four, which means that Cabinet can only submit Orders-in-Council for the Governor General's approval upon the deliberation of at least four Privy Councillors.

As such, even these sweeping memorandums nominally constrained the Prime Minister for the first half of the $20^{\text {th }}$ century from acting without at least consulting cabinet: he still had to discuss matters like the summoning, proroguing, and dissolution parliament with at least three other ministers because he advised the Governor General to promulgate those acts of the Crown via an Order-in-Council. This changed in 1953 under Prime Minister St. Laurent. The Privy Council Office created a new type of executive instrument called the "Instrument of Advice," through which the Prime Minister can by-pass Cabinet and present binding constitutional advice to the Governor General of Canada or Queen of Canada on matters within his purview -including dissolution -- directly and unilaterally. ${ }^{652}$ The Privy Council Office saw a logical progression between the memorandums regarding certain of the functions of the Prime Minister on the one hand and the instrument of advice on the other:

The order-in-council, an emanation of the Committee of the Privy Council, which has been used in the past, was considered inappropriate for this purpose, since it is the sole prerogative of the Prime Minister, and not of the Committee of the Privy Council, to advise the Governor General on these matters. ${ }^{653}$

Aucoin et al. have advocated for a reformed Canadian system virtually identical to that which the Fixed-Term Parliaments Act, 2011 has created in the United Kingdom. They advocate a constitutional amendment that would eliminate the Crown's authority over dissolution altogether such that a fixed-term parliament would dissolve automatically after four years, unless a super-majority of two-thirds of MPs vote in favour of early dissolution. ${ }^{654}$ In addition, new constitutional provisions on constructive non-confidence would replace the current conventions on confidence, thus encouraging mid-parliamentary transitions between governments and discouraging early dissolutions; other constitutional amendments still would restrict the Crown of Canada's authority over prorogation and require that parliament be summoned within 30 days after a general election. ${ }^{655}$ 
However, Aucoin et al. deviated from the British model and borrowed from

Newfoundland's fixed-date election law, which expressly mandates that the Premier must advise early dissolution under some circumstances. They acknowledge, "a change in the leader of the party that forms the government could also be a valid reason for an early dissolution," "656 even though such a proviso would contradict the intent of fixed-term parliaments and constructive non-confidence: to maintain the fixed timetable. As they emphasize, since voters elect members of parliaments and not governments, a mid-parliamentary change of government should not in and of itself justify an early dissolution. Under this reformed and "democratized" system, the initiative of dissolution "would have to come from the House, not the Prime Minister alone." Strictly speaking, however, the Commons would only initiate an early dissolution, because regular dissolutions under a fixed-term parliament would only occur on the authority of the new constitutional provision - supreme law - and not from the parliamentary privilege of the House of Commons as a chamber or of individual members, which can be exercised ad hoc and independent of a particular statutory or constitutional law. They further argue that British-style fixed-term parliaments would also prevent a Prime Minister from "capitalizing" on the "ignorance" of voters or the weakness of the Opposition. ${ }^{658}$

Finally, they argue, "Snap elections carry no benefit for the public and have been far too common in Canadian history." "659 Presumably, they would not consider an election that comes after an intra-party, mid-parliamentary change of government a snap election, because they regard early dissolution for that purpose as legitimate and even beneficial. At most, only 10 out of 42 general federal elections since 1867 could be regarded as "snap elections" (those where the Prime Minister advises early dissolution without first having lost a vote of confidence in House of Commons) - hardly a cancer on the body politic. In any case, snap elections are not aberrant broken cogs in a machine; they instead form a natural part of a healthy organism and show that things are working normally and as they should.

\section{Prospects for Reform}

Any parliament (though perhaps more likely a minority parliament) could achieve some feasible reforms in order to advance some of the same goals that Aucoin et al., Russell, and Heard set out. If a statute purports to limit how the Prime Minister can exercise the discretion to advise and take responsibility for the summoning, prorogation, or dissolution of Parliament, then it also necessarily limits how the Governor General acts on and promulgates that advice because of the foundational conventions of Responsible Government. Such a statute would therefore limit and abridge the authority of the Crown over prorogation and dissolution, which derives from sections 9 and 38 (for summoning and prorogation) and 9 and 50 (for dissolution) of the Constitution Act, 1867, and would be unconstitutional, because only an amendment under section 41(a) of the Constitution Act, 1982 can change anything "in relation to the office of the Governor General."

The best approach would be to regulate the exercise of the executive authority but without substantially restricting it or attempting to abolish it, as Anne Twomey noted in the Australian case based on precisely the same criteria that Paul Lordon set out in the Canadian case. For instance, Parliament or a provincial legislature could pass a statute requiring that it must meet at least once every, say, four to six months. Since this statutory requirement would 
exceed the minimum standard contained in section 5 of the Constitution Act, 1982 that Parliament or the legislature must meet at least every 12 months, it would not even need to be presented as a constitutional amendment passed under Section 44 Amending Formula, at the federal level, or under the comparable Section 45 Amending Formula in the provinces, though such legislation would serve as de facto constitutional amendments. ${ }^{660}$ In contrast, lengthening the maximum time that can elapse between sittings of parliament beyond 12 months certainly would require a constitutional amendment under the General Amending Formula. This proposal would leave intact the Governor General's authority to summon parliament under sections 9 and 38 of the Constitution Act, 1867 and would thus not run afoul of section 41(a) of the Constitution Act, 1982.

Parliament could also require that the first session of a new parliament after an election be summoned within a specific number of days, such as, say, 30. Parliament could probably also limit the duration of prorogations, within a reasonable timeframe that does not deviate too far from existing practice, without running afoul of section 41(a). Currently, proclamations of prorogation can state that Parliament will reconvene for despatch of business at a pro forma date, which the Prime Minister can decide to extend by advising the Governor General to issue a subsequent proclamation that extends the intersession. Such a statute could attempt to limit the intersession to, say, an absolute maximum of 60 or 70 days, or perhaps something even shorter. Similarly, Parliament has already regulated dissolution at the margins by reducing the maximum life of an individual parliament from five years to something between four and five years through the fixed-date election provision in the Canada Elections Act. Parliament could also take the approach that Stephen Harper, as Leader of the Opposition, advocated in 2004 by amending section 50 of the Constitution Act, 1982 in order to limit the maximum lifespan of the parliament directly.

In general, concrete reforms to regulate executive authority over summoning, proroguing, and dissolving parliament are more likely to be enacted in a minority parliament, over the government's initial objections but as part of a grand bargain that keeps the incumbent Ministry in office, than introduced as government legislation in a majority parliament. After all, governments are reticent to relinquish or limit their own authority, especially when it gives them a political or tactical advantage over the opposition. However, any statute or constitutional amendment designed to regulate the exercise of prorogation would require Royal Consent by Third Reading, since such legislation would directly affect an established executive prerogative authority; and, like Royal Recommendation, the Governor General grants Royal Consent only on and in accordance with the advice of the executive. ${ }^{661}$ The most likely scenario for enacting such a statute would be where a minority parliament extracts this concession from a single-party minority government as part of a larger bargain, like support for a supply bill in order to stave off an early dissolution. In other words, the Liberals, New Democrats, and Bloc Quebecois squandered their best chance at enacting this reform from the Harper government at some time between January 2009 and March 2011. However, Canadian political history shows that minority parliaments tend to cluster together (1957, 1962-1968; 1972-1974, 1979; and 2004-2011), so it stands to reason that Canadian politicians will someday have the chance to pursue this strategy once again. 


\section{Conclusion}

Sections 9 through 15 of the Constitution Act, 1867 entrench the Crown of Canada's executive authority; they are now subject to section 41(a) of the Constitution Act, 1982, which states:

An amendment to the Constitution of Canada in relation to [the office of the Queen, the Governor General and the Lieutenant Governor of a province] may be made by proclamation issued by the Governor General under the Great Seal of Canada only where authorized by resolutions of the Senate and House of Commons and of the legislative assembly of each province.

Since the "office" includes the powers and authorities of the Crown, ${ }^{662}$ only a constitutional amendment pursuant to this unanimity formula could impose an effective fixeddate elections law in Canada which mimics the British Fixed-Term Parliaments Act, 2011 and eliminates the Crown's authority over dissolution. In other words, if the House of Commons wanted to impose a British-style Fixed-term Parliaments Act, it would need the approval of the legislative assemblies of all ten provinces, and any one of those ten assemblies could prevent the House of Commons from obtaining its desired policy. (The House of Commons could wait out the Senate's suspensive veto). Similarly, if any province wanted to enact similar reforms to limit the authority of its Lieutenant-Governor, it would also need the consent of every other province. This procedure might seem like an inherently unfair and arbitrary infringement on selfgovernment, federalism, and the division of powers, but it does in fact rest on solid ground. Section 41(a) places the offices of Queen, Governor General, and the Lieutenant Governors in the same section because even though there are 11 constitutionally entrenched executives and legislatures within Canada, there is only one indivisible Crown of Canada, and thus only one source of executive authority in and over Canada, which acts, as the case may be, as the Crown of Canada in right of the Dominion of Canada, and as the Crown of Canada in right of each of the ten provinces. ${ }^{663}$ Therefore, in a highly unlikely event that the political will to implement a British-style Fixed-Term Parliaments Act in Canada ever emerged, it is possible that one constitutional amendment would have to abolish the Crown's executive authority over dissolution in Canada and all the provinces.

The British Fixed-Term Parliaments Act, 2011 clearly follows the model of putting the prerogative of dissolution into abeyance. In contrast, the Parliament of the Commonwealth of Australia and the Parliament of New Zealand both maintain classical Responsible Government and the alignment between the Governor General and the Prime Minister and operate on fixed terms of three years. The triennial maximum makes early dissolutions practically redundant, given that the average minority parliament that supports single-party minority government in Canada lives for around two years.

Decreasing the maximum life of a parliament does not fall under section 41(a) of the Constitution Act, 1982, since increasing or decreasing the life of a parliament does not derogate from the Governors' authority over dissolution, but instead under section 44 for Ottawa and section 45 for the provinces of the Constitution Act, 1982. Conversely, increasing the maximum life of the Parliament of Canada or a provincial legislature would require a constitutional amendment under the General Amending Formula to section 4(1) of the Constitution Act, 1982. But in either case, the maximum life of the legislature and the means of its dissolution are two separate questions, and the Crown could still possess the authority to dissolve parliament 
whether its maximum lifespan were three years (as in Australia at the federal level and New Zealand), or four years, or five years. The Canadian statutes have at most only limited the maximum life of a parliament to somewhere between four and five years.

Dissolution and fixed-term parliaments provide an ideal case study on the nature of the Crown and the sources executive authority in Canada versus in the United Kingdom; Canada and the United Kingdom might diverge even further on these issues, if only because the United Kingdom continues to change while Canada will remain intact and locked into the Patriation Settlement of 1982, absent a constitutional amendment. For instance, the Westminster Parliament set the first contemporary precedent for the Fixed-Term Parliaments Act, 2011 in the Scotland Act, 1998 and the Government of Wales Act, 1998 and might derive more inspiration from these devolved legislatures by eliminating prorogation and replacing it with fixed calendars, and by adopting confirmation votes for the nomination of the Prime Minister.

This comparison of the Canadian fixed-date election laws (at both the federal and provincial levels) to the British Fixed-Term Parliaments Act, 2011 highlights important differences between the British and Canadian constitutions. A proper grounding in the debate on fixed-date elections depends upon an understanding of how the Crown of Canada has evolved along a distinct path from the British Crown, particularly since 1931. The Crown of Canada derives its authority from four sources - the constitutionally entrenched authority under sections 9 to 15 of the Constitution Act, 1867, the other provisions of the Constitution Act, 1867 that confer specific authorities on the Queen or Governor General, the statutory authority that Parliament provides through delegated legislation, and the authorities that the Crown of Canada possesses as a corporation sole and legal person. In contrast, the Crown of the United Kingdom only derives its authority from three sources because the United Kingdom lacks a codified constitution: prerogative, statute, and Crown's capacity as a corporation sole and legal person.

In addition, Canadian courts might yet have to sort out the "laws of the constitution" versus the "rules of the constitution," as well as the extent to which the Parliament of Canada and provincial legislatures may regulate the authorities of the Crown that derive from either of the two constitutionally entrenched sources- like the summoning, prorogation, and dissolution of parliament - without infringing upon the offices of Queen, Governor General, and Lieutenant Governor under section 41(a) of the Constitution Act, 1982. They shall likewise also have to come to terms with the fact that perhaps contrary to its intent, the Constitution Act, 1982 has rendered Canada the most institutionally conservative of the Commonwealth Realms and as inert as a Noble Gas; in contrast, Australia and New Zealand have both innovated and deviated more widely from our British ancestor-system, and ironically, even the United Kingdom itself has of late becoming more reform-minded. The Crown of Canada's executive authority now represents a Hartzian fragment and offshoot of mid-19 $9^{\text {th }}$-century British parliamentarism, which the Constitution Act, 1982 has since ossified in place. Where the British law put the prerogative of dissolution into abeyance, the Canadian laws deliberately preserve the Crown's power of dissolution in order to avoid the political fallout associated with "opening the Constitution" of Canada; the Canadian laws have therefore largely preserved the status quo. Generally, British parliamentarians have underestimated the radicalism of the Fixed-Term Parliaments Act, 2011, while Canadian parliamentarians have downplayed the conservatism of the various federal and provincial fixed-date election laws - both for political reasons. 


\section{Endnotes}

${ }^{1}$ Peter Aucoin, Mark Jarvis, and Lori Turnbull, Democratizing the Constitution: Reforming Responsible Government (Toronto: Emond Montgomery Publications, 2011), 62-65, 81-86.

2 Adam Dodek, "The Past, Present and Future of Fixed Election Dates in Canada," Journal of Parliamentary and Political Law 4 (2010): 215-238.

${ }^{3}$ While the New Democratic MPs tabled four bills in the 1970s on fixed-term parliaments, none went beyond First Reading; they therefore failed to achieve any substantive political goal or alter public perception of the issue.

${ }^{4}$ Aucoin, Jarvis, and Turnbull 2011, 61-70. Throughout this paper, I use "Governor" and "First Minister" as generic terms that cover both the Governor General and Prime Minister at the federal level and Lieutenant Governor and Premier at the provincial level.

${ }^{5}$ Peter H. Russell, Two Cheers for Minority Government: The Evolution of Canadian Parliamentary Democracy (Toronto: Emond Montgomery Publications Limited, 2008): 134-142; Henry Milner, "Fixing Canada's Unfixed Election Dates," Institute for Research on Public Policy: Policy Matters 6, no. 6 (December 2005): 3.

${ }^{6}$ Adam Dodek, "The Past, Present and Future of Fixed Election Dates in Canada," Journal of Parliamentary and Political Law 4 (2010): 233.

${ }^{7}$ However, this paper does not venture into the discretionary authority of the Governor and the exceptional circumstances under which he should reject ministerial advice to dissolve parliament.

${ }^{8}$ James Mahoney and Kathleen Thelen, "A Theory of Gradual Institutional Change," in Explaining Institutional Change: Ambiguity, Agency, and Power, edited by James Mahoney and Kathleen Thelen, 1-37 (Cambridge: Cambridge University Press, 2010): 1.

${ }^{9}$ Mahoney and Thelen 2010, 4. Original emphasis

${ }^{10}$ Ibid., 9.

${ }^{11}$ Ibid., 2.

${ }^{12}$ Ibid., 5.

${ }^{13}$ Ibid., 3 .

${ }_{15}^{14}$ Ibid., 9.

${ }^{15}$ Ibid., 8.

${ }^{16}$ Ibid., 15.

${ }^{17}$ Ibid., 14.

${ }^{18}$ Ibid., 4.

${ }^{19}$ Ibid., 15-16.

${ }^{20}$ Ibid., 16.

${ }^{21}$ Ibid., 16.

${ }^{22}$ Ibid., 16.

${ }^{23}$ Ibid., 16.

${ }^{24}$ Ibid., 17.

${ }^{25}$ Ibid., 19.

${ }^{26}$ Ibid., 18-19.

${ }^{27}$ Ibid., 19, 22-28.

${ }^{28}$ Ibid., 20. 
29 John Van der Kiste, George II and Queen Caroline (Stroud, Gloucestershire: Sutton Publishing, 1997), 71, 118, 126, 139.

${ }^{30}$ David Starkey, Crown \& Country-The Kings \& Queens of England: A History (London: HarperPress, 2010), 419-423.

${ }^{31}$ Sebastian Payne, "The Royal Prerogative," In The Nature of the Crown: A Legal and Political Analysis, edited by Maurice Sunkin and Sebastian Payne, 77-110. (Oxford: Oxford University Press, 1999), 78.

${ }^{32}$ Paul Lordon, Crown Law (Ottawa: Ministry of Supply and Services, 1991), 65; Margit Cohn, "Medieval Chains, Invisible Inks: On Non-Statutory Powers of the Executive," Oxford Journal of Legal Studies 25, no. 1 (2005): 105.

${ }^{33}$ Peter Hogg, Constitutional Law of Canada. $5^{\text {th }}$ Edition Supplemented (Toronto: Thomson Reuters, 2011): 1-18.

34 Payne 1999, 79.

35 Payne 1999, 106-107.

${ }^{36}$ Anne Twomey, "Pushing the Boundaries of Executive Power - Pape, the Prerogative and Nationhood Powers," Melbourne University Law Review 34 (2010): 325.

${ }^{37}$ Ibid., [my emphasis].

${ }^{38}$ A.V. Dicey, Introduction to the Study of the Laws of the Constitution, ed. Roger E. Michener (Indianapolis: Liberty Fund 1982), 282; Peter Hogg, Constitutional Law of Canada. $5^{\text {th }}$ Edition Supplemented. (Toronto: Thomson Reuters, 2011): 1-18.

${ }^{39}$ Hogg 2011, 1-19.

${ }^{40}$ Margit Cohn, "Medieval Chains, Invisible Inks: On Non-Statutory Powers of the Executive," Oxford Journal of Legal Studies 25, no. 1 (2005): 104.

${ }^{41}$ Sir William Blackstone, Commentaries on the Laws of England in Four Books. Notes selected from the editions of Archibald, Christian, Coleridge, Chitty, Stewart, Kerr, and others, Barron Field's Analysis, and Additional Notes, and a Life of the Author by George Sharswood. In Two Volumes, Volume 1, Books I \& II, edited by George Sharswood (Philadelphia: J.B. Lippincott Co., 1893), 475, 469; Philippe Lagassé, "The Crown's Power of Command-in-Chief: Interpreting Section 15 of Canada's Constitution Act, 1867," Review of Constitutional Studies 18, no. 2 (2013): 195.

${ }^{42}$ Blackstone 1893, 238.

${ }^{43}$ B.S. Markensinis, "The Royal Prerogative Revisited," Cambridge Law Journal 32, no. 2 (November 1973): 287; Attorney-General v De Keyser's Royal Hotel Ltd. 1920 A.C. 508 at 526; Burmah Oil Co Litd. V Lord Advocate [1965] A.C. 75 at 99; Khadr v. Canada (Attorney General) (F.C.), 2006 FC 727, at para 87; Blackv Canada (Jean Chretien and the Attorney General), 2001 DLR $\left(4^{\text {th }}\right) 228$, at para 25.

${ }^{44}$ Margit Cohn, "Medieval Chains, Invisible Inks: On Non-Statutory Powers of the Executive," Oxford Journal of Legal Studies 25, no. 1 (2005): 104.

${ }^{45}$ Payne 1999, 86.

${ }^{46}$ Cohn 2005, 104.

${ }^{47}$ Robert Craig, "Restoring Confidence: Replacing the Fixed-Term Parliaments Act, 2011" The Modern Law Review 81, no.3 (2018), 497.

${ }^{48}$ B.V. Harris, "The 'Third Source' of Authority for Government Action," The Law Quarterly Review 109 (October 1992) 
${ }^{49}$ The Crown of New Zealand is like the Crown of the United Kingdom because both countries operate on uncodified constitutions, while the Crown of Australia is like the Crown of Canada because both of these federal constitutional monarchies possess hybrid constitutions consisting of both codified and uncodified components. The Crown of Zealand therefore also draws on this "third source," while the Crown of Australia counts it as the "fourth source." However, the fourth source of authority of the Crown of Canada is probably more limited than that of the Crown of Australia because the Charter of Rights and Freedoms imposes clear limitations on the executive governments and legislatures in Canada, at both the federal and provincial levels. In contrast, Australia lacks an entrenched bill of rights.

${ }^{50}$ Harris 1992, 650.

${ }^{51}$ Twomey 2010, 326.

${ }^{52}$ Cohn 2005, 110. Cohn cites HL Debates, vol. 645, col. WA 12 (25 February 2003).

${ }^{53}$ Harris 1992, 626-627.

${ }^{54}$ Harris 1992, 627.

${ }^{55}$ Harris 1992, 647.

${ }^{56}$ Harris 1992, 645.

57 Twomey 2010, 326.

${ }^{58}$ United Kingdom, Parliament of the United Kingdom. Regency Act, 1937, chapter 16, 1 Edward VIII and 1 George VI. Section 8 of the Act defines "royal functions" as "all powers and authorities belonging to the Crown, whether prerogative or statutory." This statute omits any mention of the Ram Doctrine and the Crown's powers as a legal person because Ram did not write his legal brief until the 1940s.

${ }^{59}$ Lordon, 1991, 67.

${ }^{60}$ Ibid.

${ }^{61}$ Philippe Lagassé, “The Crown's Power of Command-in-Chief: Interpreting Section 15 of Canada's Constitution Act, 1867," Review of Constitutional Studies 18, no. 2 (2013): 195.

${ }^{62}$ Payne 1999, 108.

${ }^{63}$ Robert Craig, "Restoring Confidence: Replacing the Fixed-Term Parliaments Act, 2011" The Modern Law Review 81, no.3 (2018)

${ }^{64}$ Lordon 1991, 17. Lordon says, "The executive may act pursuant to specific constitutional or statutory authority, pursuant to common law or prerogative authority, or in ways that are purely incidental to the Crown's status as a person or a corporation sole."

${ }^{65}$ Henri Brun, Guy Tremblay, and Eugénie Brouillet, Droit constitutionnel. 5th Ed. (Montréal : Éditions Yvon Blais, 2008): 364. « Les actes que sont appelés à poser le gouverneur général et le lieutenant-governeur résultent soit de la Constitution, soit de prérogatives coutumières, soit de délégations qui leur soit faites par voie législative. Mais selon les selon les conventions constitutionnelles, de tels actes sont posés conformément à l'avis reçu des gouvernements en fonction. "

${ }^{66}$ Philippe Lagassé, "Canadian Command-in-Chief: Executive Power and Section 15 of Canada's Constitution Act, 1867," paper presented at the Canadian Political Science Association's Annual Conference, 5 June 2013.

${ }^{67}$ Operation Dismantle v. The Queen [1985] 1 S.C.R. 441, at para. 63.

${ }^{68}$ Ibid. 
${ }^{69}$ Warren J. Newman, “Of Dissolution, Prorogation, and Constitutional Law, Principle and Convention: Maintaining Fundamental Distinctions During a Parliamentary Crisis," National Journal of Constitutional Law 27 (2009): 219.

${ }^{70}$ Christopher McCreery, "Myth and Misunderstanding: The Origins and Meaning of the Letters Patent Constituting the Office of the Governor General 1947," Chapter 3 in The Evolving Canadian Crown, edited by Jennifer Smith and D. Michael Jackson, 31 -56 (Montreal-Kingston: McGill-Queen's University Press, 2011), 32. As McCreery shows, the Queen of the Canadanot the Governor General - remains the source of the constitutional powers and authorities by virtue of section 9 of the Constitution Act, 1867. This is why Letters Patent have delegated, not transferred, authority from the Queen, who personifies the Crown, to the Governor General, who represents the Queen.

${ }^{71}$ Newman 2009, 229.

72 Newman 2009, 222.

${ }^{73}$ Janet Ajzenstat, The Once and Future Canadian Democracy (Montreal-Kingston: The McGill-Queen's University Press, 2003), 64.

${ }^{74}$ Lordon 1991, 61-62.

${ }^{75}$ Arthur Berridale Keith, Responsibility Government in the Dominions, Volume 3 (Oxford: Clarendon Press, 1912), 1562. Summoning opens a session, and prorogation ends a session. Until the early $20^{\text {th }}$ century, the Governor General both opened (summoned) and closed (prorogued) a session of Parliament by a speech from the throne.

${ }^{76}$ Lordon 1991, 5.

${ }^{77}$ Ibid.

${ }^{78}$ Newman 2009, 219.

${ }^{79}$ Twomey 2010, 324.

80 Ibid.

${ }^{81}$ Ibid. In Australia, "statute may also abrogate equivalent prerogative powers," but only through express, clear intent. ${ }^{81}$ The Commonwealth of Australia Constitution Act does not contain a provision equivalent to section 41(a) of the Constitution Act, 1982; the offices of the Queen of Australia and Governor General of Australia are therefore not necessarily subject to alteration only through constitutional amendment, as they are in Canada.

${ }^{82}$ Philippe Lagassé, "Canadian Command-in-Chief: Executive Power and Section 15 of Canada's Constitution Act, 1867," paper presented at the Canadian Political Science Association's Annual Conference, 5 June 2013.

${ }^{83}$ D. Michael Jackson, The Crown and Canadian Federalism (Toronto: Dundurn, 2013), 57-58. In Operation Dismantle, Justice Wilson refers only to Cabinet decisions based on prerogative and statute. Operation Dismantle v. The Queen [1985] 1 S.C.R. 441, at para 50.

${ }^{84}$ Peter W. Hogg, Patrick J. Monahan, and Wade K. Wright, Liability of the Crown, $4^{\text {th }}$ Edition (Toronto: Carswell, 2011), 18.

${ }^{85}$ Ibid.

${ }^{86}$ Ibid., 19.

${ }^{87}$ Khadr v. Canada (Prime Minister), 2010 FC 715, [2010] 4 F.C.R. 36, at para. 59.

${ }^{88}$ David E. Smith, The People's House of Commons: Theories of Democracy in Contention (Toronto: University of Toronto Press, 2007): 29; Robert Macgregor Dawson, "The Constitutional Question," Dalhousie Review VI, no. 3 (October 1926): 333. 
${ }^{89}$ Philippe Lagassé, "Parliamentary and Judicial Ambivalence Toward Executive Prerogative Powers in Canada," Canadian Public Administration 55, no. 2 (June 2012): 157-180.

${ }^{90}$ Khadr v. Canada (Attorney General) (F.C.), 2006 FC 727, at para 79.

${ }^{91}$ Ibid., at para 87.

${ }^{92}$ Ibid., at para 88.

93 Ibid., at para 88 .

${ }^{94}$ Black v Canada (Jean Chretien and the Attorney General), 2001 DLR (4 ${ }^{\text {th }}$ ) 228, at para 39.

${ }^{95}$ Canada. Privy Council Office, Manual of Official Procedure of the Government of

Canada, Henry F. Davis and André Millar. (Ottawa: Government of Canada, 1968): 93.

${ }^{96}$ Conacher v. Canada (Prime Minister), 2009 FC 920, at para 10.

${ }^{97}$ Ibid., at para 25.

${ }^{98} \mathrm{Ibid} .$, , at para 25.

99 Ibid., , at para 26.

${ }^{100}$ Ibid., , at para. 26.

${ }^{101}$ Ibid., , at para. 68.

${ }^{102}$ Ibid., , at para. 53.

${ }^{103}$ Conacher v. Canada (Prime Minister), 2009 FC 920 (Memorandum of Fact and Law of the Respondent at para 43).

${ }^{104}$ A.V. Dicey, Introduction to the Study of the Laws of the Constitution, ed. Roger E. Michener (Indianapolis: Liberty Fund 1982), 282.

${ }^{105}$ Dale Gibson, "Monitoring Arbitrary Government Authority: Charter Scrutiny of

Legislative, Executive, and Judicial Privilege," Saskatchewan Law Review 61 (1998): 306-310.

${ }^{106}$ Re Initiative and Referendum Act, [1919] A.C. 935 (P.C.), at para. 7.

107 Ibid.

${ }^{108}$ Ibid., at para. 3.

${ }^{109}$ Re Initiative and Referendum Act, [1919] A.C. 935 (P.C.), at para. 11; Gibson 1998, 308-309.

${ }^{110}$ Re Manitoba Language Rights, [1985] 1 S.C.R. 721, at para. 135

111 Gibson 1998, 307.

${ }^{112}$ Warren J. Newman and Robert Nicholson in Canada, Senate, Minutes of the

Proceedings of the Standing Committee on Legal and Constitutional Affairs, 21 March 2013.

${ }^{113}$ Canada, Parliament, Senate. Minutes of the Proceedings of the Standing Committee

on Legal and Constitutional Affairs, 21 March 2013. Warren J. Newman and Minister Rob

Nicholson appeared before the committee on the Succession to the Crown Bill; at various times, they defined "Office of Queen" as the "powers," "rights," "prerogatives," and "constitutional status" of the Queen.

${ }^{114}$ Newman 2009, 223.

${ }^{115}$ New Brunswick Broadcasting Co. v. Nova Scotia (Speaker of the House of Assembly),

[1993] 1 S.C.R. 319

${ }^{116}$ Ibid., at 85.

${ }^{117}$ Reference re Remuneration of Judges of the Provincial Court (P.E.I.), [1997] 3 S.C.R. 3, at paras. 108, 139.

${ }^{118}$ Lagassé 2013, 189-220; Gibson 1998, 297-321. 
${ }^{119}$ Barry Strayer, Canada's Constitutional Revolution (Edmonton: University of Alberta Press, 2013), 163-164.

${ }^{120}$ Gibson 1998,: 309.

${ }^{121}$ Strayer 2013, 179-180 and 204-206.

${ }^{122}$ Newman 2009, 222.

${ }^{123}$ Strayer, 2013, 163-164.

${ }^{124}$ Lagassé 2013, 195; Philippe Lagassé and James W.J. Bowden, “The Crown as Corporation Sole and the Royal Succession: A Critique of Canada's Succession to the Throne Act, 2013," Constitutional Forum 23, no. 1 (April 2014), 17-26; Lordon 1991, 5.

${ }^{125}$ William Renwick Riddell, "Lecture II: The Written Constitution," in The Constitution of Canada in Its History and Practical Workings. (New Haven, CT: Yale University Press, 1917), 52. The "Supreme Court of Ontario" has since been reorganized and renamed the "Superior Court of Ontario."

${ }^{126}$ For instance, it would be unconstitutional (in the English sense), but not illegal, if the Governor were to act unilaterally and independent of any ministerial advice.

${ }^{127}$ Russell Kirk, The Roots of American Order, 4th Edition (Wilmington, Delaware: Isi Books, 2003), 66, 83.

${ }^{128}$ Martin A. Rogoff, "A Comparison of Constitutionalism in France and the United States," Maine Law Review 49, no. 21 (1997): 22-83.

${ }^{129}$ Nicholas A. MacDonald, "The Expanding Constitution of Canada”, forthcoming project

${ }^{130}$ Re: Resolution to Amend the Constitution [1981] 1 S.C.R., at para 874.

${ }^{131}$ Ibid., at para 883-884.

${ }^{132}$ Nicholas A. MacDonald, "The Expanding Constitution of Canada", forthcoming project; Nicholas A. MacDonald, conversation with author, September 2013.

${ }^{133}$ Conacher v. Canada (Prime Minister), 2009 FC 920, at para. 59.

${ }^{134}$ Re: Resolution to Amend the Constitution [1981] 1 S.C.R., at pages 876-878

${ }^{135}$ Nicholas A. MacDonald, "The Expanding Constitution of Canada", forthcoming project; Nicholas A. MacDonald, conversation with author, September 2013.

${ }^{136}$ Re: Resolution to Amend the Constitution [1981] 1 S.C.R., at pages 883-884

${ }^{137} \mathrm{Re}$ : Reference re Secession of Quebec, [1998] 2 S.C.R. 217, at para. 148

${ }^{138}$ Reference re Senate Reform, 2014 SCC 32 at para 23, [2014] 1 SCR 704, citing:

Reference re Secession of Quebec, [1998] 2 SCR 217, 161 DLR (4th) 385 at paras 32 and 70-78 [cited to SCR]; Reference re Remuneration of Judges of the Provincial Court (P.E.I.), [1997] 3 SCR 3, 150 DLR (4th) 577 at para 108 [cited to SCR]; Constitution Act, 1982, being Schedule B to the Canada Act 1982 (UK), 1982, c 11, s 52(1); Supreme Court Act Reference, 2014 SCC 21 at para 89 [Citations omitted].

139 Ibid., at para 25, citing Secession Reference, at para. 32; Secession Reference; Provincial Court Judges Reference; New Brunswick Broadcasting Co. v. Nova Scotia (Speaker of the House of Assembly), [1993] 1 S.C.R. 319; Reference re Manitoba Language Rights, [1985] 1 S.C.R. 721 [Citations omitted].

${ }^{140}$ Ibid., at para 26.

141 Ibid., at page 27.

${ }^{142}$ Reference re Senate Reform, 2014 SCC 32, at para. 24, citing Supreme Court Act Reference, 2014 SCC 21 at paras. 97-100; Secession Reference, at para. 32 [Citations omitted]. 
${ }^{143}$ Heather MacIvor, "Unwritten Constitutional Principles," Journal of Parliamentary and Political Law 6, no. 2 (August 2012): 339.

${ }^{144}$ Dennis Baker, Not Quite Supreme: The Courts and Coordinate Constitutional Interpretation (McGill-Queen's University Press, 2010), 61-63; Philippe Lagassé, conversation with author, November 2012.

${ }^{145}$ Lise Trudel Thibeault v. Sa Majesté la Reine [2013] R.J.Q. 1, at para. 10.

${ }^{146}$ Sir John George Bourinot, Parliamentary Procedure and Practice, $4^{\text {th }}$ ed. (Montreal:

Dawson Brothers Publishing, 1916): 102.

${ }^{147}$ Newman 2009, 225; Bourinot 1916, 102; Conacher v. Canada (Prime Minister), 2009

FC 920 (Memorandum of Fact and Law of the Respondent at para. 13).

${ }^{148}$ R. Macgregor Dawson, The Government of Canada. $5^{\text {th }}$ ed. (1970), revised by

Norman Ward (Toronto: University of Toronto Press, 1947): 175.

${ }^{149}$ Sir John George Bourinot, Parliamentary Procedure and Practice. $1^{\text {st }}$ ed. (Montreal:

Dawson Brothers Publishing, 1884): 58.

${ }^{150}$ Eugene Forsey and Graham C. Eglington, The Question of Confidence in Responsible Government (Ottawa: Parliament of Canada, 1985), 13-14.

${ }^{151}$ Newman 2009, 222; Richard Berthelsen, correspondence with author, 4 August 2012.

${ }^{152} R e$ : Resolution to Amend the Constitution [1981] 1 S.C.R., at para 883-884; Re:

Reference re Secession of Quebec, [1998] 2 S.C.R. 217, at para. 148; Reference re Senate

Reform, 2014 SCC 32 at para 23; Adam Dodek, The Canadian Constitution (Toronto: Dundurn, 2013), 17-18.

${ }^{153}$ Warren Newman, "Constitutional Amendment by Legislation," chapter 5 in

Constitutional Amendment in Canada, edited by Emmett Macfarlane, 105-125 (Toronto:

University of Toronto Press, 2016): 105.

${ }^{154}$ Objection by Quebec to a Resolution to amend the Constitution, [1982] 2 S.C.R. 793, at page 806; Hogan v. Newfoundland (Attorney General), 2000 NFCA 12 at para. 64, 73.

${ }^{155}$ Russell 2003, 52.

${ }^{156}$ Ibid., $52-53$.

${ }^{157}$ Newman 2016, 105.

${ }^{158}$ Canada, Department of Justice, A Consolidation of the Constitution Acts, 1867 to 1982

(Ottawa: Her Majesty the Queen in Right of Canada, 1 January 2001), 74.

${ }^{159}$ Newman 2016, 106.

${ }^{160}$ Newman 2016, 112-115.

${ }^{161}$ Peter Aucoin, Mark Jarvis, and Lori Turnbull, Democratizing the Constitution: Reforming Responsible Government (Toronto: Emond Montgomery Publishing, 2011), 26.

${ }^{162}$ Christopher McCreery, "Myth and Misunderstanding: The Origins and Meaning of the Letters Patent Constituting the Office of the Governor General 1947," Chapter 3 in The Evolving Canadian Crown, edited by Jennifer Smith and D. Michael Jackson, 31-56 (Montreal-Kingston: McGill-Queen's University Press, 2011), 32. As McCreery shows, the Queen of the Canada not the Governor General - remains the source of the constitutional powers and authorities by virtue of section 9 of the Constitution Act, 1867. This is why the Letters Patent have delegated, not transferred, authority from the Queen, who personifies the Crown, to the Governor General, who represents the Queen.

${ }^{163}$ Sir John George Bourinot, Parliamentary Procedure and Practice, $4^{\text {th }}$ ed. (Montreal: Dawson Brothers Publishing, 1916): 102. 
${ }^{164}$ Canada. Privy Council Office, Manual of Official Procedure of the Government of Canada, Henry F. Davis and André Millar. (Ottawa, Government of Canada, 1968): 77-79. ${ }^{165}$ Canada, Department of Canadian Heritage, Ceremonial and Protocol Handbook. (Ottawa: Government of Canada, c. 1998): G.4-2; Henri Brun, Guy Tremblay, and Eugénie Brouillet, Droit constitutionnel. 5th Ed. (Montreal : Éditions Yvon Blais, 2008): 371. ${ }^{166}$ Robert Macgregor Dawson, "The Constitutional Question," Dalhousie Review VI, no. 3 (October 1926): 332-337; Eugene Forsey and Graham C. Eglington, The Question of Confidence in Responsible Government (Ottawa: Parliament of Canada, 1985), 16-17. ${ }^{167}$ Bourinot 1916, 102; R. Macgregor Dawson, The Government of Canada. $5^{\text {th }}$ ed. (1970), revised by Norman Ward (Toronto: University of Toronto Press, 1947): 175.

${ }^{168}$ Incidentally, this system also follows Machiavelli's advice in Chapter 19 of The Prince of delegating bad tasks to ministers. See: Niccoli Machiavelli, The Prince, translated by Harvey C. Mansfield, Jr. (Chicago: The University of Chicago Press, 1985), 75. And the principle of the inviolability of the Sovereign apply to the Glorious Revolution, too: even in the Bill of Rights, 1689, the Convention Parliament assiduously avoids blaming the person of the King which it just deposed, instead assigning responsibility to the "diverse evill Councellors Judges and Ministers imployed by him."See: 1688 Chapter 2, 1 William and Mary Session 2.

${ }^{169}$ Sir John George Bourinot, Parliamentary Procedure and Practice. $1^{\text {st }}$ ed. (Montreal: Dawson Brothers Publishing, 1884): 58.

${ }^{170}$ Alpheus Todd, Parliamentary Government in the British Colonies, $2^{\text {nd }}$ Edition (London: Longmans, Green, and Co., 1894), 760-761.

${ }^{171}$ Seals Act, R.S.C., 1985 , c. S-6.

${ }_{172}$ Aucoin et al. 2011, 217.

${ }^{173}$ Hogg et al. 2011, 25.

${ }^{174}$ Janet Ajzenstat, The Once and Future Canadian Democracy: An Essay in Political Thought (McGill-Queen's University Press, 2003), 64, 66-67.

${ }^{175}$ Canada. Privy Council Office, "Order-in-Council Regarding Prerogatives of the Prime Minister," Manual of Official Procedure of the Government of Canada: Appendices, Henry F. Davis and André Millar.(Ottawa, Government of Canada, 1968): 717; Canada. Privy Council Office, Access to Information Request on Instruments of Advice, A-2015-00504, page 1; Canada. Privy Council Office, Access to Information Request on Instruments of Advice, A2015-00304, page 4 .

176 Janet Ajzenstat, The Once and Future Canadian Democracy: An Essay in Political Thought (McGill-Queen's University Press, 2003), 65-67; Dennis Baker, “"The Real Protection of the People': The Royal Recommendation and Responsible Government," Journal of Parliamentary and Political Law 4 (2010); Dennis Baker, Not Quite Supreme: The Courts and Coordinate Constitutional Interpretation (McGill-Queen's University Press, 2010), 61.

${ }^{177}$ John Lambton (The Earl of Durham), The Report and Despatches of the Earl of Durham, Her Majesty's High Commissioner and Governor-General of British North America (London: Ridgways, 1839), 211.

${ }^{178}$ David E. Smith, The Invisible Crown: The First Principle of Canadian Government (Toronto: University of Toronto Press, 1995), 66.

${ }^{179}$ Ibid., 122. 
${ }^{180}$ Dennis Baker, “'The Real Protection of the People': The Royal Recommendation and Responsible Government," Journal of Parliamentary and Political Law 4 (2010): 213.

${ }^{181}$ Ibid., 207.

182 Dennis Baker, “"The Real Protection of the People': The Royal Recommendation and Responsible Government," Journal of Parliamentary and Political Law 4 (2010): 207; Janet Ajzenstat, The Once and Future Canadian Democracy (Montreal-Kingston: The McGillQueen's University Press, 2003), 65.

${ }^{183}$ Dennis Baker, Not Quite Supreme: The Courts and Coordinate Constitutional Interpretation (McGill-Queen's University Press, 2010), 62.

${ }^{184}$ Eugene Forsey, How Canadians Govern Themselves $7^{\text {th }}$ Ed (Ottawa: Her Majesty the Queen in Right of Canada, 2007), 25-27.

${ }^{185}$ Daniel Hannan, "David Cameron Should Give Scotland Full Fiscal Autonomy Immediately," Cap X Author, 8 May 2015.

${ }^{186}$ Peter Neary, “Confidence: How Much Is Enough?” Constitutional Forum constitutionnel 18, no. 1 (2009): 51-54; United Kingdom. Cabinet Office, The Cabinet Manual - Draft: A Guide to Laws, Conventions and the Rules on the Operations of Government (London: Crown Copy-right, December 2010): 25.

${ }^{187}$ Philip Norton, "Government Defeats in the House of Commons: The British Experience," Canadian Parliamentary Review (Winter 1985-1986): 6.

${ }^{188}$ Kenneth Newton and Jan W. Van Deth, Foundations of Comparative Politics: Democracies in the Modern World, 2nd Edition (Cambridge University Press, 2010), 100; David Judge and David Earnshaw, The European Parliament, 2nd Edition (Hampshire: PalgraveMacmillian, 2008), 16. Mark Kesselman et al, Introduction to Comparative Politics: Political Challenges and Changing Agendas, 7th Edition (Boston: Cengage Learning, 2016), 99; Alan Fenna et al., Government and Politics in Australia (Frenchs Forest, New South Wales: Pearson Australia), 15; Mark Garnett and Philip Lynch, Exploring British Politics, 4th Edition (London: Routledge, 2016), page number not provided for some daft reason; Ronald L. Watts, Executive Federalism: A Comparative Analysis (Kingston, Ontario: Queen's University, Institute of Intergovernmental Relations, 1989), 7.

${ }^{189}$ Alpheus Todd, Parliamentary Government in the British Colonies, 2nd Edition (London: Longmans, Green, and Co., 1894), 26.

${ }^{190}$ Rod Hague and Martin Harrop, Political Science: A Comparative Introduction, 5th Edition. (New York: Palgrave-MacMillan, 2007), 336.

${ }^{191}$ Janet Ajzenstat, "Bicameralism and Canada's Founders: The Origins of the Canadian Senate," in Protecting Canadian Democracy: The Senate You Never Knew, ed. Serge Joyal (Toronto: University of Toronto Press, 2003): 3, 7.

${ }^{192}$ Ibid., 7.

${ }^{193}$ Sir William Blackstone, Commentaries on the Laws of England in Four Books. Notes selected from the editions of Archibald, Christian, Coleridge, Chitty, Stewart, Kerr, and others, Barron Field's Analysis, and Additional Notes, and a Life of the Author by George Sharswood. In Two Volumes, Volume 1, Books I \& II, edited by George Sharswood (Philadelphia: J.B. Lippincott Co., 1893), 187.

194 Sir John George Bourinot, Parliamentary Procedure and Practice, $4^{\text {th }}$ ed. (Montreal: Dawson Brothers Publishing, 1916): 102. 
${ }^{195}$ R. Macgregor Dawson, The Government of Canada. $5^{\text {th }}$ ed. (1970), revised by

Norman Ward (Toronto: University of Toronto Press, 1947): 175.

196 "No House of Commons and no legislative assembly shall continue for longer than

five years from the date fixed for the return of the writs at a general election of its members."

${ }^{197}$ Constitutional Act, 179131 George III, chapter 31, section 27; Act of Union, 18413 \&

4 Victoria, chapter 35, section 31.

198 Janet Ajzenstat, The Canadian Founding: John Locke and Parliament (Montreal-

Kingston: McGill-Queen's University Press, 2007), 120.

199 The Clergy Endowments (Canada) Act 1791, (31 George 3, c. 31)

${ }^{200}$ British North America Act, 1840, (3 \& 4 Victoria, c.35).

${ }^{201}$ Canada. Privy Council Office, Manual of Official Procedure of the Government of

Canada, Henry F. Davis and André Millar. (Ottawa: Government of Canada, 1968): 407.

${ }^{202}$ Canada Gazette, "Proclamation Dissolving Parliament," 28 March 2011; Canada

Gazette, "Proclamation Issuing Writs of Election," 28 March 2011; Canada

Gazette, "Proclamation Summoning Parliament to Meet on 31 May 2011," 28 March 2011.

${ }_{203}$ Canada Gazette, "Proclamation Dissolving Parliament," 28 March 2011.

${ }^{204}$ Canada Gazette, "Proclamation Issuing Writs of Election," 28 March 2011.

${ }^{205}$ Canada Gazette, "Proclamation Summoning Parliament to Meet on 31 May 2011," 28

March 2011.

${ }^{206}$ Geoffrey Elton, The Tudor Revolution in Government: Administrative Changes in the

Reign of Henry VIII (Cambridge University Press, 1953).

${ }^{207}$ Audrey O'Brien and Marc Bosc, House of Commons Procedure and Practice, 2nd Ed.

(Ottawa: House of Commons and Editions Yvon Blais, 2009), 386.

${ }^{208}$ Blackstone 1893, 469.

${ }^{209}$ In contrast, the Sovereign owns certain properties like Sandringham and Balmoral in his or her natural capacity, so they do not automatically transfer to the Sovereign's heirs and successor's upon a demise of the Crown, but instead in accordance with standard laws on wills and inheritance of property.

${ }^{210}$ United Kingdom, The Gazette: London Gazette, "Dissolution Proclamation," (London: Crown Copyright, 12 April 2010), issue 59388, page number 6393.

${ }^{211}$ United Kingdom, Prime Minister's Office, 10 Downing Street, "Press Release: State Opening of Parliament to Take Place on 27 May 2015," 26 March 2015.

${ }^{212}$ United Kingdom, The Gazette: London Gazette, "Proclamations: By the Queen A Proclamation For Declaring the Calling of a New Parliament," (London: Crown Copyright, 31 March 2105), issue 61188, page number, 6014.

${ }^{213}$ William Arnold Peters, in Canada, House of Commons, Bill C-112: An Act to amend the British North America Acts, 1867 to 1965, (duration of House of Commons), 28 ${ }^{\text {th }}$ Parliament, $4^{\text {th }}$ Session, 25 February 1972.

${ }^{214}$ William Arnold Peters, in Canada, House of Commons, Bill C-112: An Act to amend the British North America Acts, 1867 to 1965, (duration of House of Commons), $28^{\text {th }}$ Parliament, $4^{\text {th }}$ Session, 25 February 1972.

215 Douglas Rowland, in Canada, House of Commons, Bill C-123: An Act to amend the British North America Acts, 1867 to 1965, (duration of House of Commons), $28^{\text {th }}$ Parliament, $4^{\text {th }}$ Session, 25 February 1972.

216 Ibid. 
${ }^{217}$ As Schwartz and Buck point out, "the most significant change created by the fixed date election legislation is the reduction of Parliament's maximum duration from five years to four years." Bryan Schwartz and Andrew Buck, "Fixed Date Elections," Manitoba Law Journal 5 (2008): 7.

${ }^{218}$ Bryan Schwartz and Andrew Buck, "Fixed Date Elections," Manitoba Law Journal 5 (2008): 1 .

219 Ibid.

${ }^{220}$ Ibid., 9.

${ }^{221}$ Dodek 2010, 233.

${ }^{222}$ Preston Manning, 56 Reasons Why You Should Support the Reform Party of Canada (Calgary: Reform Party of Canada, 1992).

${ }^{223}$ Reform Party of Canada, Platform of Statements and Principles (Calgary: Reform Party of Canada, 1988), 9.

${ }^{224}$ Canadian Alliance, A Time for Change: An Agenda of Respect for All Canadians The Plan (Calgary: Canadian Alliance, 2000), 19-20.

${ }^{225}$ Eugene A. Forsey, How Canadians Govern Themselves, $8^{\text {th }}$ Ed. (Ottawa: Her Majesty the Queen in Right of Canada, 2007), 5.

${ }^{226}$ Canada. Privy Council Office, Manual of Official Procedure of the Government of Canada, Henry F. Davis and André Millar.(Ottawa, Government of Canada, 1968): 407; Guy Tremblay and Hubert Cauchon, "Étude détaillée du projet de loi no 3, Loi modifiant la Loi électorale afin de prévoir des elections à date fixe." In Quebec, National Assembly, Journal des débats de la Commission des institutions 43, no. 62, 5 June 2013.

${ }^{227}$ Conservative Party of Canada, Demand Better: Platform, 2004 (Ottawa: Conservative Party of Canada, 2004), 12.

${ }^{228}$ Robert Macgregor Dawson. "The Constitutional Question." Dalhousie Review VI, no. 3 (October 1926): 332-337; Eugene Forsey and Graham C. Eglington, The Question of Confidence in Responsible Government (Ottawa: Parliament of Canada, 1985), 16-17.

${ }^{229}$ Canada, House of Commons, An Act to provide fixed dates for the election of members to the House of Commons and to amend the Constitution Act, 1867. Bill C-512, 37 $7^{\text {th }}$ Parliament, $3^{\text {rd }}$ Session, 2004.

${ }^{230}$ Conservative Party of Canada, Stand Up For Canada: Federal Election Platform, 2006 (Ottawa: Conservative Party of Canada, 2006), 44.

${ }^{231}$ Canada, House of Commons, An Act to amend the Canada Elections Act. Bill C-16, $39^{\text {th }}$ Parliament, $1^{\text {st }}$ session, 2006.

${ }^{232}$ Conacher v Canada (Prime Minister), 2009 FC 920 (Memorandum of Fact and Law of the Respondent at para 16).

${ }^{233}$ Robert Nicholson, in Canada, House of Commons, Evidence, Standing Committee on Procedure and House Affairs, $39^{\text {th }}$ Parliament, $1^{\text {st }}$ Session, No. 18, Tuesday, 26 September 2006 (Ottawa: Parliament of Canada, 2006), 2.

${ }^{234}$ Ibid.

235 Ibid., 11.

${ }^{236}$ Ibid., 21:48.

${ }^{237}$ CBC News, "Layton Predicts Fall Election Call After Meeting with Harper," 30 August 2008. 
${ }^{238}$ Juliet O’Neill, “PM Not Bound By Election Date Law; Harper May Push for New Mandate," The Windsor Star, 21 August 2008, A10.

${ }^{239}$ Les Whittington, "Bring On Fall Elections, Liberals Say; Party Increasingly Confident It's in Good Position As Tories Deal With Scandals, Stagnant Popularity," The Toronto Star, 2 August 2008, A17; Juliet O’Neill, “Harper, Dion Skirmish over Fall Election; PM Plans to Meet With All Three Opposition Party Leaders to Find Out Whether a 'Productive' Session Is Possible," The Vancouver Sun, 20 August 2008, A4; Allan Woods, "PM to Meet with Duceppe, Layton As Vote Call Looms; Launch of Election Campaign Expected As Early As Next Week, Pre-empting Three By-Elections," The Toronto Star, 29 August 2008, A19.

${ }^{240}$ Chantal Hebert, "PM Will Get His Wish," Telegraph-Journal, 28 August 2008, A7.

${ }^{241}$ Errol Mendes, “Harper's Snap Election Call Would Violate 'Principle' He Fought

For; It Will Take Some Twisted Rhetoric to Justify Breaking With Fixed Election Date," Edmonton Journal, 29 August 2008, A16; Michael Behiels, "Prime Minister Dancing With The Law," Prince Albert Daily Herald, editorial, 6 September 2008, A4; Trish Audette, "Dion Launches Liberal Election Campaign in Alberta; "Some Constitutional Experts Are Saying This Election Will Be Illegal,' Leader Says,” The Ottawa Citizen, 6 September 2008, A7; Richard Brennan, "PM Changes Tune on Need for Fixed Date," Toronto Star, 4 September 2008, A16; Clark Campbell, Bill Currey, and Murray Campbell, "Be Ready For Fall Election, Harper Warns," The Globe and Mail, 20 August 2008, A1; Denis Smith, "Is The Fix in on Fixed Election Law?" The Globe and Mail, 21 August 2008, A17; Andrew Dreschel, "PM's Poll Talk Sounds Like Hypocrisy; Fall Vote Would Contradict Tories' Fixed Election Date Law," The Hamilton Spectator, 27 August 2008, A17; Prince Albert Daily Herald, editorial, Dancing Through the Fixed-Election Loophole, 13 September 2008, 4; Peter Rosenthal, "The Case that Tuesday's Vote Is Illegal; The Group Challenging the PM's Election Call Says It's More Than a Flip-Flop From His Own Law Fixing Election Dates. It's A Transgression The Courts Must Reckon With," The Toronto Star, 11 October 2008; Jeffrey Simpson, "The Advantage - and Risk - Is Harper's," The Globe and Mail, 8 September 2008, A1; Paul Wells, "We Oppose LateTerm Abortions, Er, Rather, Elections," Maclean's, volume 121, issue 35-36 (8 September 2008), 15 .

${ }^{242}$ L. Ian MacDonald, "Harper Has An Out; A Clause in the Fixed-Date Election Law Allows the Prime Minister to Call An Election Whenever He Chooses," Montreal Gazette, 18 August 2008, A17; Denis Smith, "Is The Fix in on Fixed Election Law?" The Globe and Mail, 21 August 2008, A17; Juliet O’Neill, "PM Not Bound By Election Date Law; Harper May Push for New Mandate," The Windsor Star, 21 August 2008, A10; Chantal Hebert, "PM Will Get His Wish," Telegraph-Journal, 28 August 2008, A7.

${ }^{243}$ Andrew Heard, "Conacher Missed the Mark on Constitutional Conventions and Fixed Election Dates," Constitution forum constitutionnel 19, no. 1 (2010): 21-32; Andrew Heard, "Constitutional Conventions: The Heart of the Living Constitution," Journal of Parliamentary and Political Law 6, no. 2 (August 2012): 319-338; Peter H. Russell, Two Cheers for Minority Government: The Evolution of Canadian Parliamentary Democracy (Toronto: Emond Montgomery Publications Limited, 2008), 139. Russell wrote this book before Harper's early dissolution and argued, "Prime Minister Harper seems inclined to abide by what should now be regarded as a convention of the constitution and not request dissolution merely for partisan advantage." Democracy Watch quoted Peter Russell in Conacher v. Canada (Prime Minister), 2009 FC 920 (Memorandum of Fact and Law of the Respondent at para. 50). 
${ }^{244}$ Susan Delacourt, “Anyone in the Mood for a Summer Election?” iPolitics, 12 June 2018; Andrew Coyne, "A Snap Election? Unlikely, But with the Obstacles Ahead, Liberals May Be Tempted," National Post, 22 June 2018; Chantal Hebert, "Why Canadians Deserve a Federal Election This Fall," The Toronto Star, 13 August 2018; Susan Delacourt, "Conditions Are Almost Perfect for a Snap Election," iPolitics, 15 August 2018; Robin Sears, "Early Federal Election Rumours Build," The Toronto Star, 8 September 2018.

${ }^{245}$ James W.J. Bowden and Nicholas A. MacDonald, "Writing the Unwritten: The Officialization of Constitutional Conventions in Canada, the United Kingdom, New Zealand, and Australia," Journal of Parliamentary and Political Law 6, no 2 (August 2012): 367.

${ }^{246}$ Bowden and MacDonald 2012, 367; James W.J. Bowden and Nicholas A.

MacDonald, "Cabinet Manuals and the Crown," Chapter 12 in Canada and the Crown: Essays on Constitutional Monarchy, edited by D. Michael Jackson and Philippe Lagassé, 179-195.

(Kingston-Montreal: Queen's-McGill University Press, 2013), 180.

${ }^{247}$ Bowden and MacDonald 2012, 368; Brian Slattery, "Why the Governor General

Matters," in Parliamentary Democracy in Crisis, edited by Peter Russell and Lorne Sossin (Toronto: University of Toronto, 2009): 85.

${ }^{248}$ Bowden and MacDonald 2012, 368.

${ }^{249}$ Andrew Heard, "Constitutional Conventions and Parliament." Canadian

Parliamentary Review (Summer 2005): 20.

${ }^{250}$ Conacher v. Canada (Prime Minister), 2009 FC 920

${ }^{251}$ Conacher v Canada 2011 FCA 131

${ }^{252}$ Conacher v. Canada (Prime Minister), 2009 FC 920 (Memorandum of Fact and Law

of the Applicant at para. 37).

${ }^{253}$ Dodek 2010, 215-238.

${ }^{254}$ Conacher v. Canada (Prime Minister), 2009 FC 920 (Memorandum of Fact and Law

of the Applicant at para. 63).

${ }^{255} \mathrm{Ibid}$., at para. 55).

${ }^{256}$ Dodek 2010, 226

${ }^{257}$ Heard 2010, 21-22.

${ }^{258}$ Dodek 2010, 227.

${ }^{259}$ Adrienne Clarkson, Heart Matters (Toronto: Viking Canada, 2006), 192.

${ }^{260}$ Dodek 2010, 228.

${ }^{261}$ Russell 2008, 140.

${ }^{262}$ Conacher v. Canada (Prime Minister), 2009 FC 920 (Memorandum of Fact and Law

of the Respondent at para. 50).

${ }^{263}$ Ibid., at para. 51).

${ }^{264}$ Corbett Haselgrove Spurin, "Chapter 5: Constitutional Conventions," in

Constitutional and Administrative Law (Corbett Haselgrove Spurin, 2004), 3.

${ }^{265}$ Heard 2010, 26.

${ }^{266} \mathrm{Ibid}$.

${ }^{267}$ Forsey and Eglington 1985, 18-19.

${ }^{268}$ Dodek 2010, 228;

${ }^{269}$ Conacher v. Canada (Prime Minister), 2009 FC 920 (Memorandum of Fact and Law of the Respondent at para. 12).

${ }^{270}$ Ibid., at para. 13). 
${ }^{271}$ Ibid., at para. 16).

272 Ibid., at para. 24).

${ }^{273}$ Conacher v. Canada (Prime Minister), 2009 FC 920 (Memorandum of Fact and Law of the Applicant at paras. 3-10).

${ }^{274}$ Conacher v. Canada (Prime Minister), 2009 FC 920, para 55.

${ }^{275}$ Andrew Heard, "Constitutional Conventions: The Heart of the Living Constitution," Journal of Parliamentary and Political Law 6, no. 2 (August 2012):319-338.

${ }^{276}$ For a fuller description, see James W.J. Bowden and Nicholas A. MacDonald, "Writing the Unwritten: The Officialization of Constitutional Convention in Canada, the United Kingdom, New Zealand, and Australia," Journal of Parliamentary and Political Law 6 no. 2 (August 2012), 367-372.

277 Conacher v. Canada (Prime Minister), 2009 FC 920, at para. 47.

${ }^{278}$ Prime Minister R.B. Bennett, "The Statute of Westminster" in Canada, House of

Commons, House of Commons Debates (Hansard), $17^{\text {th }}$ Parliament, $2^{\text {nd }}$ Session (30 June 1931), 3191-3224.

${ }^{279}$ Andrew Heard, "Constitutional Conventions: The Heart of the Living Constitution," Journal of Parliamentary and Political Law 6, no. 2 (August 2012): 333.

280 Ibid., 335.

${ }^{281}$ Ibid., $327,337$.

${ }^{282}$ Forsey and Eglington 1985, 16.

${ }^{283}$ Heard 2010, 21.

${ }^{284}$ Ibid., 31.

285 Dodek 2010, 227

${ }^{286}$ Susana Mas, "Conservative Nominations Raise Odds of Early 2015 Election: NDP Lags Liberals, Tories in Party Nominations in Advance of Next Election," CBC News, 20 June 2014 http://www.cbc.ca/news/politics/conservative-nominations-raise-odds-of-early-2015election-1.2640482; Mia Rabson, "Will He Or Won't He? Election Speculation Continues in Ottawa," Winnipeg Free Press, 3 October 2014 http://www.winnipegfreepress.com/opinion/columnists/will-he-or-wont-he-277986761.html; Lawrence Martin, "Harper's Election Timing? Expect the Unexpected," The Globe and Mail, 30 September 2014 http://www.theglobeandmail.com/globe-debate/harpers-election-timing-expectthe-unexpected/article20842873/; Abbas Rana, "PM Harper Could Justify Calling An Early Election, Say Former PMO Advisors," The Hill Times, 13 October 2014 http://www.hilltimes.com/news/news/2014/10/13/pm-harper-could-justify-calling-an-earlyelection-say-former-pmo-advisers/39895; R. Michael Warren, "Why Stephen Harper Will Call an Early Election," Toronto Star, 9 November 2014 http://www.thestar.com/opinion/commentary/2014/11/09/why_stephen_harper_will_call_an_earl y_election.html. 2016.

${ }^{287}$ Parliament of Canada, ParlInfo, “Length of Federal Election Campaigns," 26 August

${ }^{288}$ Canada Elections Act (S.C. 2000, c. 9)

${ }^{289}$ Parliament of Canada, ParlInfo, "Length of Federal Election Campaigns," 26 August 2016. As ParlInfo shows, the $42^{\text {nd }}$ general election lasted the longest of all elections on which the writs for all ridings were made returnable on the same day; the only general election that went on longer occurred in 1872 (up to 89 days), when the Governor General's proclamation specified 
that the return of writs for the remote northern ridings of Algoma and Saguenay would occur later than those in the rest of the country.

${ }^{290}$ Alaister MacGregor, ["Bill C-279, An Act to Amend the Canada Elections Act (length of election period)"], Canada, Parliament of Canada, 42nd Parliament, 1st Session, 31 May 2016. ${ }^{291}$ Canada, House of Commons. Bill C-76, An Act to Amend the Canada Elections Act and Other Acts and to Make Certain Consequential Amendments, $42^{\text {nd }}$ Parliament, $1{ }^{\text {st }}$ Session, 64-65-66-67 Elizabeth II, 2015-2016-2017-2018, 30 April 2018, page 26.

${ }^{292}$ Canada, House of Commons. Bill C-76, An Act to Amend the Canada Elections Act and Other Acts and to Make Certain Consequential Amendments, $42^{\text {nd }}$ Parliament, ${ }^{\text {st }}$ Session, 64-65-66-67 Elizabeth II, 2015-2016-2017-2018, 30 April 2018, page 5.

${ }^{293}$ Canada. Privy Council Office, Manual of Official Procedure of the Government of Canada, Henry F. Davis and André Millar. (Ottawa, Government of Canada, 1968): 89-90. Nicholas MacDonald and I have written on this subject at greater length in another article. The Manual of Official Procedure of the Government of Canada also treats the issue as "the Principle of Restraint."

${ }^{294}$ Canada. Privy Council Office, Guidelines on the Conduct of Ministers, Secretaries of State, Exempt Staff and Public Servants During An Election. (Ottawa: Her Majesty the Queen in Right of Canada, 2008): 1.

${ }^{295}$ Carl Baar and Peter Russell, "Why Won't the Liberals Act on Harper's Overreach on Appointments?" Globe and Mail, 28 March 2016.

${ }^{296}$ New Zealand, Cabinet Office, Department of the Prime Minister and Cabinet, Cabinet Manual (Wellington: Her Majesty the Queen in Right of New Zealand, 2008), 76-77.

${ }^{297}$ Ibid.

${ }^{298}$ British Columbia, Constitution Act, RSBC 1996, Chapter 66.

${ }^{299}$ British Columbia, Legislature of British Columbia, Hansard, 37th Parliament, $2^{\text {nd }}$ Session, Volume 2, no. 21, Monday, 20 August 2001.

${ }^{300}$ Ibid.

301 Ibid.

${ }^{302}$ Kenyon Wallace, "BC Premier Gordon Campbell Resigns," National Post, 3

November 2010.

${ }^{303}$ Leonard Korg ["Election"] In British Columbia, Legislature of British Columbia, Hansard, 39th Parliament, $3^{\text {rd }}$ Session, Volume 20, no. 8, Wednesday, 27 April 2011.

${ }^{304}$ Norm Macdonald, ["Election"] In British Columbia, Legislature of British Columbia, Hansard, 39th Parliament, $3^{\text {rd }}$ Session, Volume 20, no. 3, Tuesday, 15 February 2011.

${ }^{305}$ Bob Simpson, ["Bill M-204: Fall Fixed-date elections Amendment Act, 2011"] In British Columbia, Legislature of British Columbia, Hansard, 39th Parliament, $3^{\text {rd }}$ Session, Volume 21, no. 2, Thursday, 5 May 2011.

${ }^{306}$ EKOS Politics and iPolitics, "BC NDP Currently Poised to Form Next Provincial Government," 14 February 2013. This study included an EKOS Poll conducted in late 2012, near when the New Democrats wanted an election, showed that the Liberals only commanded the support of $23 \%$ of British Columbians and would therefore have lost power.

${ }^{307}$ David Elby in ["Bill 5 - Constitution Amendment Act, 2017'] in British Columbia, Legislative Assembly, Hansard, $41^{\text {st }}$ Parliament, $2^{\text {nd }}$ Session, no. 29, 4 October 2017, 794.

${ }^{308}$ David Elby in [“Bill 5 - Constitution Amendment Act, 2017”] in British Columbia, Legislative Assembly, Hansard, $41^{\text {st }}$ Parliament, $2^{\text {nd }}$ Session, no. 36, 18 October 2017, 1106. 
${ }^{309}$ Lisa Beare in ["Bill 5 - Constitution Amendment Act, 2017”] in British Columbia, Legislative Assembly, Hansard, $41^{\text {st }}$ Parliament, $2^{\text {nd }}$ Session, no. 36, 18 October 2017, 1109. ${ }^{310}$ Andrew Wilkinson in ["Bill 5 - Constitution Amendment Act, 2017"] in British Columbia, Legislative Assembly, Hansard, $41^{\text {st }}$ Parliament, $2^{\text {nd }}$ Session, no. 36, 18 October 2017, 1106.

${ }^{311}$ Andrew Wilkinson in ["Bill 5 - Constitution Amendment Act, 2017"] in British Columbia, Legislative Assembly, Hansard, $41^{\text {st }}$ Parliament, $2^{\text {nd }}$ Session, no. 36, 18 October 2017, 1107.

312 Ibid., 1109.

${ }^{313}$ Andrew Weaver in ["Bill 5 - Constitution Amendment Act, 2017"] in British Columbia, Legislative Assembly, Hansard, $41^{\text {st }}$ Parliament, $2^{\text {nd }}$ Session, no. 36, 18 October 2017, 1113.

${ }^{314}$ John Rustad in ["Bill 5 - Constitution Amendment Act, 2017'] in British Columbia, Legislative Assembly, Hansard, 41 ${ }^{\text {st }}$ Parliament, $2^{\text {nd }}$ Session, no. 41, 24 October 2017, 1307.

${ }^{315}$ David Elby in ["Bill 5 - Constitution Amendment Act, 2017'] in British Columbia, Legislative Assembly, Hansard, $41^{\text {st }}$ Parliament, $2^{\text {nd }}$ Session, no. 41, 24 October 2017, 1300. ${ }^{316}$ Andrew Wilkinson in ["Bill 5 - Constitution Amendment Act, 2017"] in British Columbia, Legislative Assembly, Hansard, $41^{\text {st }}$ Parliament, $2^{\text {nd }}$ Session, no. 36, 18 October 2017, 1107.

${ }^{317}$ Lisa Beare in ["Bill 5 - Constitution Amendment Act, 2017"] in British Columbia, Legislative Assembly, Hansard, $41^{\text {st }}$ Parliament, $2^{\text {nd }}$ Session, no. 36, 18 October 2017, 1109. 318 Justin McElroy, "BC Green Party Agrees to Support NDP in the Legislature," CBC News, 29 May 2017;

$<$ http://www.cbc.ca/news/canada/british-columbia/bc-ndp-green-agreement-1.4136539>

BC Green Caucus and BC New Democrat Caucus, 2017 Confidence and Supply Agreement Between the BC Green Caucus and the BC New Democratic Caucus, 29 May 2017, 2.

$<$ http://bcndpcaucus.ca/wp-content/uploads/sites/5/2017/05/BC-Green-BC-NDPAgreement_vf-May-29th-2017.pdf>

${ }^{319}$ David Elby in [“Bill 5 - Constitution Amendment Act, 2017”] in British Columbia, Legislative Assembly, Hansard, $41^{\text {st }}$ Parliament, $2^{\text {nd }}$ Session, no. 41, 24 October 2017, 1317.

${ }^{320}$ Newfoundland and Labrador, House of Assembly Act, RSNL1990, Chapter H-10.

${ }^{321}$ Newfoundland and Labrador, House of Assembly. An Act to Amend the House of Assembly Act and the Elections Act, 1991, 45 ${ }^{\text {th }}$ General Assembly, $1^{\text {st }}$ Session, 53 Elizabeth II, 2004.

${ }^{322}$ Newfoundland and Labrador, House of Assembly. Bill 40: An Act to Amend the House of Assembly Act and the Elections Act, 1991, 45 ${ }^{\text {th }}$ General Assembly, ${ }^{\text {st }}$ Session, 53 Elizabeth II, 2004.

${ }^{323}$ Ed Byrne, in ["Fixed Election,"] In Newfoundland and Labrador, House of Assembly, Hansard, $35^{\text {th }}$ General Assembly, $1^{\text {st }}$ Session, Volume 45, no. 53, 7 December 2004.

${ }^{324}$ Jack Harris, in ["Fixed-date elections"] In Newfoundland and Labrador, House of Assembly, Hansard, $35^{\text {th }}$ General Assembly, $1^{\text {st }}$ Session, Volume 45, no. 53, 7 December 2004.

${ }^{325}$ Interpretation Act, R.S.C. 1985, c. I-21; Ruth Sullivan, Statutory Interpretation (Toronto: Irwin Law, 2007), 73.

${ }^{326}$ John Pepall, Against Reform (Toronto: University of Toronto, 2010), 155. 
327 Ibid.

${ }^{328}$ Ibid.

${ }^{329}$ CBC News, "Tom Marshall Sworn in as $11^{\text {th }}$ Premier," 24 January 2014.

${ }^{330}$ Globe and Mail, "Newfoundland Tories Re-Start Leadership Contest with September 13 Vote," 20 June 2014. http://www.theglobeandmail.com/news/politics/newfoundland-toriesrestart-leadership-contest-with-sept-13-vote/article19257468/.

${ }^{331}$ Sue Baily, "Paul Davis to Become Next Premier of Newfoundland and Labrador," Globe and Mail, 13 September 2014.

http://www.theglobeandmail.com/news/politics/newfoundlands-pc-leadership-vote-heads-tothird-ballot/article20593075/\#dashboard/follows/.

${ }^{332}$ Sue Baily, "New Newfoundland and Labrador Premier Vows Action on Crime and Mental Health," Globe and Mail, 26 September 2014 http://www.theglobeandmail.com/news/politics/newfoundlands-new-premier-vows-action-oncrime-mental-health/article20815567/\#dashboard/follows/.

${ }^{333}$ Victor Power, Letter to Dwight Ball, Paul Davis, and Earle McCurdy, 13 May 2015.

${ }^{334}$ Ibid.

${ }^{335}$ Ibid.

${ }^{336}$ Dwight Ball, ["Oral Questions"] in Newfoundland and Labrador, House of Assembly, Hansard, 47th General Assembly, 4th Session, Volume XLVII, No. 26 (4 June 2015), 1258.

${ }^{337}$ Premier Davis, ["Oral Questions"] in Newfoundland and Labrador, House of Assembly, Hansard, 47th General Assembly, 4th Session, Volume XLVII, No. 26 (4 June 2015), 1258-1259.

${ }^{338}$ Dwight Ball, ["Oral Questions"] in Newfoundland and Labrador, House of Assembly, Hansard, 47th General Assembly, 4th Session, Volume XLVII, No. 26 (4 June 2015), 1260.

${ }^{339}$ Newfoundland and Labrador, House of Assembly, An Act to Amend the House of Assembly Act, Bill 13, 47th Legislature, 4th Session, Volume XLVII, No. 28 (9 June 2015), 1389; Newfoundland and Labrador, House of Assembly, An Act to Amend the House of Assembly Act, Bill 13, 47th Legislature, 4th Session, Volume XLVII, No. 32 (16 June 2015), 1606.

${ }^{340}$ James Bennett, ["Second Reading, Bill 13"] in Newfoundland and Labrador, House of Assembly, Hansard, 47th General Assembly, 4th Session, Volume XLVII, No. 32 (16 June 2015), 1606.

${ }^{341}$ Ibid., 1608.

${ }^{342}$ Ibid., 1609.

${ }^{343}$ Newfoundland and Labrador, House of Assembly, An Act to Amend the House of Assembly Act, Bill 13, 47th Legislature, 4th Session, Volume XLVII, No. 28, 2015.

${ }^{344}$ Ontario, Legislative Assembly. An Act to Amend the Elections Act, The Election Finances Act, and the Legislative Assembly Act, to Repeal the Representation Act, 1996, and to Enact the Representation Act, 2005. Bill 176, 38 ${ }^{\text {th }}$ Legislature, $1^{\text {st }}$ Session, 2005.

${ }^{345}$ Michael Bryant, ["Election Statute Law Amendment Act, 2005,"] In Ontario, Legislative Assembly of Ontario, Hansard, $38^{\text {th }}$ Legislature, $1^{\text {st }}$ Session, Thursday, 5 May 2005. ${ }^{346}$ Peter Kormos, [“Election Statute Law Amendment Act, 2005,"] In Ontario, Legislative Assembly of Ontario, Hansard, $38^{\text {th }}$ Legislature, $1^{\text {st }}$ Session, Thursday, 5 May 2005. ${ }^{347}$ CBC News, "Wynne Says Ontario Could See Election If Bills are Blocked," 9 September 2013. 
${ }^{348}$ Ibid.

349 Ibid.

${ }^{350}$ Richard Brennan and Robert Benzie, "Kathleen Wynne Promises No Snap Election If Tories Hold Leadership Race," Toronto Star, 20 September 2013.

351 Ontario, Lieutenant Governor of Ontario, "Constitutional Role: Prorogation and Dissolution," (Toronto: Queen's Printer for Ontario, 2014).

${ }^{352}$ Robert Benzie and Rob Ferguson, "Ontario heading for election next month as NDP rejects budget: A June election is a certainty after NDP Leader Andrea Horwath said her party could not support the budget tabled by Premier Kathleen Wynne's minority," Toronto Star, 2 May 2014. http:/www.thestar.com/news/queenspark/2014/05/02/ontario heading_for_election_next month as ndp rejects budget.html

${ }^{353}$ CBC News, "Ontario Election 2014: Wynne Vows to Reintroduce Budget - Kathleen Wynne Granted Late Spring Election by Lt.-Gov. David Onley," 2 May 2014. I obtained the Premier's statement from the video link embedded in the article.

$<$ http://www.cbc.ca/news/canada/toronto/ontario-election-2014-wynne-vows-to-re-introducebudget-1.2629948>

${ }^{354}$ Ontario, Legislative Assembly. An Act to Amend the Elections Act, The Election Finances Act, and the Legislative Assembly Act, to Repeal the Representation Act, 1996, and to Enact the Representation Act, 2005; Office of the Premier, "Ontario Election on June 2 ${ }^{\text {nd }}, 2014$," 2 May 2014 http://www.premier.gov.on.ca/en/news/29476.

${ }^{355}$ Elections Ontario, Ready, Set, Go! Managing Ontario's 41st General Election (Toronto: Queen's Printer, 2014), 16.

${ }^{356}$ Ontario, Newsroom, "Government Introduces Election Reform Legislation to Ensure Fair Representation: Proposed Measures Would Increase Number of Ontario Ridings to 122," 4 June 2015. <https://news.ontario.ca/opo/en/2015/06/government-introduces-election-reformlegislation-to-ensure-fair-representation.html $>$

357 Yasir Naqvi, ["First Reading: Bill 45"] in Ontario, Legislative Assembly of Ontario, Official Report of Debates (Hansard), 41st Parliament, 2nd Session, No. 17, 19 October 2016, 850; Lieutenant Governor Dowdeswell, ["Royal Assent"], in Ontario, Legislative Assembly of Ontario, Official Report of Debates (Hansard), 41st Parliament, 2nd Session, No. 42, 8 December 2016, 2240.

${ }^{358}$ Keith Leslie and Allison Jones, "Wynne Shuffles Cabinet Halfway Through Mandate to Put Fresh Face on Government," Canadian Press, 16 June 2016. $<$ https://www.nationalnewswatch.com/2016/06/13/wynne-shuffles-cabinet-halfway-throughmandate-to-put-fresh-face-on-government/\#.WwNwFe4vzIW>; Steve Paikin, "You Don't Have to Wait Until 2018 to See Provincial Election Campaigns," Steve Paikin's Blog, 20 September 2016. <https://tvo.org/blog/current-affairs/you-dont-have-to-wait-till-2018-to-see-provincialelection-campaigns $>$; Robert Benzie and Robert Ferguson, "Kathleen Wynne Prorogues Legislature for Throne Speech Monday," Toronto Star, 8 September 2016. $<$ https://www.thestar.com/news/queenspark/2016/09/08/wynne-to-prorogue-the-legislature-forthrone-speech-monday.html $>$.

${ }^{359}$ Steve Paikin, Tweet to James W.J. Bowden, 22 September 2016.

$<$ https://twitter.com/spaikin/status/778930916349644800> 
${ }^{360}$ France Gelinas, ["Second Reading: Bill 45"] in Ontario, Legislative Assembly of Ontario, Official Report of Debates (Hansard), 41st Parliament, 2nd Session, No. 23, 31 October 2016, 1200.

${ }^{361}$ Attorney General Naqvi, ["Second Reading: Bill 45"] in Ontario, Legislative Assembly of Ontario, Official Report of Debates (Hansard), 41st Parliament, 2nd Session, No. 22, 27 October 2016, 1101.

${ }^{362}$ Victor Fedeli, ["Second Reading: Bill 45"] in Ontario, Legislative Assembly of Ontario, Official Report of Debates (Hansard), 41st Parliament, 2nd Session, No. 25, 2 November 2016, 1285.

363 Julia Munro, ["Second Reading: Bill 45"] in Ontario, Legislative Assembly of Ontario, Official Report of Debates (Hansard), 41st Parliament, 2nd Session, No. 26, 3 November 2016, 1344.

364 Tim Arnott, ["Second Reading: Bill 45"] in Ontario, Legislative Assembly of Ontario, Official Report of Debates (Hansard), 41st Parliament, 2nd Session, No. 26, 3 November 2016, 1336.

${ }^{365}$ Ibid.

${ }^{366}$ Bev Harrison, [“First Reading: Bill 11"] in New Brunswick, Legislative Assembly. Journal of Debates (Hansard), $56^{\text {th }}$ Assembly, $1^{\text {st }}$ Session, 9 February 2007 (Fredericton: New Brunswick Legislative Assembly, 2007), 30.

${ }^{367}$ Bev Harrison, ["Second Reading: Bill 11"] in New Brunswick, Legislative Assembly. Journal of Debates (Hansard), $56^{\text {th }}$ Assembly, $1^{\text {st }}$ Session, 13 February 2007 (Fredericton: New Brunswick Legislative Assembly, 2007), 67.

${ }^{368}$ Stuart Jamieson, [“First Reading: Bill 75”] in New Brunswick, Legislative Assembly. Journal of Debates (Hansard), 56 ${ }^{\text {th }}$ Assembly, $1^{\text {st }}$ Session, 29 May 2007 (Fredericton: New Brunswick Legislative Assembly, 2007), 30.

${ }^{369}$ Stuart Jamieson, ["Second Reading: Bill 75"] in New Brunswick, Legislative Assembly. Journal of Debates (Hansard), 56 ${ }^{\text {th }}$ Assembly, $1^{\text {st }}$ Session, 30 May 2007 (Fredericton: New Brunswick Legislative Assembly, 2007), 37.

370 Ibid.

${ }^{371}$ Paul Robichaud, ["Seconds Reading: Bill 75"] in New Brunswick, Legislative Assembly. Journal of Debates (Hansard), 56 ${ }^{\text {th }}$ Assembly, $1^{\text {st }}$ Session, 30 May 2007 (Fredericton: New Brunswick Legislative Assembly, 2007), 37-38.

372 James W.J. Bowden, "When the Bell Tolls for Parliament: Dissolution by Efflux of Time," Journal of Parliamentary and Political Law 11, no. 1 (2017): 129-144.

${ }^{373}$ Paul Robichaud, ["Seconds Reading: Bill 75"] in New Brunswick, Legislative Assembly. Journal of Debates (Hansard), 56 ${ }^{\text {th }}$ Assembly, $1^{\text {st }}$ Session, 30 May 2007 (Fredericton: New Brunswick Legislative Assembly, 2007), 38.

${ }^{374}$ Lieutenant-Governor, ["Royal Assent"] in New Brunswick, Legislative Assembly. Journal of Debates (Hansard), 56 ${ }^{\text {th }}$ Assembly, $1^{\text {st }}$ Session, 26 June 2007 (Fredericton: New Brunswick Legislative Assembly, 2007), 57.

${ }^{375}$ New Brunswick, Legislative Assembly. An Act to Amend the Legislative Assembly Act. Bill 75, 56 ${ }^{\text {th }}$ Legislature, $1^{\text {st }}$ Session, 2007.

${ }^{376}$ New Brunswick, Chapter E-3, Elections Act (Fredericton: Queen's Printer for New Brunswick, 2015), 25. 
${ }^{377}$ New Brunswick, The Royal Gazette, volume 172 (Fredericton: the Queen's Printer, Wednesday, 3 September 2014), 1575-1576.

${ }^{378}$ New Brunswick, Executive Council Office, Order-in-Council 2014-346, 13 August 2014.

${ }^{379}$ Manitoba, Legislative Assembly. An Act to Amend the Elections Act, $39^{\text {th }}$ Legislative Assembly, 2008

${ }^{380}$ Glen Cummings ["Bill 205-The Legislative Assembly Amendment Act (Set Date Elections)"], Manitoba, Legislative Assembly, Debates and Proceedings: Official Report (Hansard), $38^{\text {th }}$ Legislature, $3^{\text {rd }}$ Session, Vol. LVI No. 41, (Winnipeg: Legislative Assembly of Manitoba): 2304.

${ }^{381}$ Manitoba, Legislative Assembly. The Legislative Assembly Amendment Act (Set Date Elections), Bill 205, $38^{\text {th }}$ Legislature, $3^{\text {rd }}$ Session, 2005.

${ }^{382}$ Stephen Clarkson, "Securing Their Future Together: The Liberals in Action," Chapter 3 in The Canadian General Election of 1997, edited by Alan Frizzell and Jon H. Pammett, 39-70 (Toronto: Dundurn Press, 1997), 43.

383 Ibid

${ }^{384}$ Steve Ashton, [“Bill 37'], Manitoba, Legislative Assembly, Debates and Proceedings: Official Report (Hansard), $39^{\text {th }}$ Legislature, $2^{\text {nd }}$ Session, Vol. LX, No. 39 (Winnipeg: Legislature of Manitoba): 2051.

${ }^{385}$ Manitoba, Legislative Assembly. The Elections Amendment Act, Bill 37, 39 ${ }^{\text {th }}$ Legislature, $2^{\text {nd }}$ Session, 2008.

${ }^{386}$ Kevin Lamoureux, [“Bill 37”], Manitoba, Legislative Assembly, Debates and Proceedings: Official Report (Hansard), $39^{\text {th }}$ Legislature, $2^{\text {nd }}$ Session, Vol. LX, No. 39 (Winnipeg: Legislature of Manitoba, 12 May 2008): 2052.

${ }^{387}$ Gerald Hawranik and Larry Maguire, [“Bill 37”], Manitoba, Legislative Assembly, Debates and Proceedings: Official Report (Hansard), $39^{\text {th }}$ Legislature, $2^{\text {nd }}$ Session, Vol. LX, No. 39 (Winnipeg: Legislature of Manitoba, 12 May 2008): 3134-3136.

${ }^{388}$ Larry Maguire, ["Bill 37"], Manitoba, Legislative Assembly, Debates and Proceedings: Official Report (Hansard), $39^{\text {th }}$ Legislature, $2^{\text {nd }}$ Session, Vol. LX, No. 39 (Winnipeg: Legislature of Manitoba, 12 May 2008): 3135.

${ }^{389}$ Larry Maguire, ["Bill 37"], Manitoba, Legislative Assembly, Debates and Proceedings: Official Report (Hansard), $39^{\text {th }}$ Legislature, $2^{\text {nd }}$ Session, Vol. LX, No. 81B (Winnipeg: Legislature of Manitoba, 7 October 2008): 3832-3833.

${ }^{390}$ Leonard Derkach, ["Bill 37"], Manitoba, Legislative Assembly, Debates and

Proceedings: Official Report (Hansard), $39^{\text {th }}$ Legislature, $2^{\text {nd }}$ Session, Vol. LX, No. 81B

(Winnipeg: Legislature of Manitoba, 7 October 2008): 3846.

${ }^{391}$ Manitoba, Legislative Assembly. The Election Financing Act and Elections Amendment Act. Bill 33, 40 ${ }^{\text {th }}$ Legislature, $1^{\text {st }}$ session, 2012.

${ }^{392}$ Kelvin Goertzen, ["Bill 33 - The Election Financing Act and Elections Amendment Act"], in Manitoba, Legislative Assembly, Debates and Proceedings: Official Report (Hansard), $40^{\text {th }}$ Legislature, $1^{\text {st }}$ Session, 7 June 2012 Vol. LXIV, No. 47B (Winnipeg: Legislature of Manitoba, 2012), 2266.

${ }^{393}$ Mavis Taillieu, ["Bill 33 - The Election Financing Act and Elections Amendment Act”], in Manitoba, Legislative Assembly, Debates and Proceedings: Official Report (Hansard), 
$40^{\text {th }}$ Legislature, $1^{\text {st }}$ Session, 7 June 2012 Vol. LXIV, No. 51B (Winnipeg: Legislature of Manitoba, 2012), 2505. (emphasis added)

${ }^{394}$ Jennifer Howard, ["Bill 33 - The Election Financing Act and Elections Amendment Act"], in Manitoba, Legislative Assembly, Debates and Proceedings: Official Report (Hansard), $40^{\text {th }}$ Legislature, $1^{\text {st }}$ Session, 7 June 2012 Vol. LXIV, No. 51B (Winnipeg: Legislature of Manitoba, 2012), 2506.

395 Jennifer Howard, ["Bill 33 - The Election Financing Act and Elections Amendment Act"], in Manitoba, Legislative Assembly, Debates and Proceedings: Official Report (Hansard), $40^{\text {th }}$ Legislature, $1^{\text {st }}$ Session, 7 June 2012 Vol. LXIV, No. 51B (Winnipeg: Legislature of Manitoba, 2012), 2506.

${ }^{396} \mathrm{Ibid}$.

${ }^{397}$ Ibid.

${ }^{398}$ Elections Manitoba, "Manitoba's Set Date Election Moves to April 2016," 5 January 2015.

${ }^{399}$ Elections Manitoba, "Manitoba's Set Election Date Moves to April 2016," 5 January

2015. <http://www.electionsmanitoba.ca/downloads/Change_to_set_date_NR.pdf $>$

${ }^{400}$ Saskatchewan, Legislative Assembly. An Act to Amend the Legislative Assembly and

Executive Council Act. Bill 4, $26^{\text {th }}$ Legislature, $1^{\text {st }}$ Session, 2008.

${ }^{401}$ Darcy McGovern, ["Fixed Election Dates"] In Saskatchewan, Legislative Assembly.

Hansard Verbatim Report, Standing Committee on Intergovernmental Affairs and Justice, $26^{\text {th }}$

Legislature, $1^{\text {st }}$ Session, No. 6, 21 April 2008 (Regina: Legislative Assembly of Saskatchewan, 2008), 106-107.

${ }^{402}$ Don Morgan ["Fixed Election Dates"] In Saskatchewan, Legislative Assembly.

Hansard Verbatim Report, Standing Committee on Intergovernmental Affairs and Justice, $26^{\text {th }}$

Legislature, $1^{\text {st }}$ Session, No. 6, 21 April 2008 (Regina: Legislative Assembly of Saskatchewan, 2008), 107.

${ }^{403}$ Saskatchewan, Legislative Assembly. An Act to Amend the Legislative Assembly and

Executive Council Act, 2007. Bill 35, 27 ${ }^{\text {th }}$ Legislature, $1^{\text {st }}$ Session, 2012.

${ }^{404}$ Don Morgan, ["Bill No. 35 - An Act to Amend the Legislative Assembly and Executive

Council Act, 2007'] In Saskatchewan, Legislative Assembly. Hansard Verbatim Report,

Standing Committee on Intergovernmental Affairs and Justice, $27^{\text {th }}$ Legislature, $1{ }^{\text {st }}$ Session, No.

10, 8 May 2012 (Regina: Legislative Assembly of Saskatchewan, 2008), 208.

${ }^{405}$ Saskatchewan, The Legislative Assembly Act, 2007, Chapter L-11.3 (Regina: The

Queen's Printer, 2017), 7-8.

$<$ http://www.publications.gov.sk.ca/freelaw/documents/English/Statutes/Statutes/L11-

3.pdf $>$

${ }^{406}$ Joe Couture, "Wall to Seek Third Term," The Star Phoenix, 26 February 2014.

${ }^{407}$ Murray Mandryk, "Premier Messing With Election Date," The Leader-Post, 14

January 2014.

${ }^{408}$ Michael Boda, Chief Electoral Officer's Discussion Paper: Resolving the Municipal-

Provincial Election Timing Problem in Saskatchewan (Regina: Elections Saskatchewan, April

2017), 1.

${ }^{409}$ Ibid., 4.
${ }^{410}$ Ibid., 6. 
${ }^{411}$ CBC News, “A Very Difficult Decision': Premier Scott Moe Unveils New Cabinet," 2 February 2018 [accessed 24 May 2018]. <http://www.cbc.ca/news/canada/saskatoon/premierscott-moe-sworn-in-sask-1.4516424>

412 CBC News, "Premier Shouldn't Wait Until 2020 to Call Election: Saskatchewan NDP Leader," 9 March 2018 [accessed 24 May 2018].

$<$ http://www.cbc.ca/news/canada/saskatchewan/saskatchewan-general-election-ryan-meili-scottmoe-1.4570783>

${ }^{413}$ Prince Edward Island, Legislative Assembly. An Act to Amend the Elections Act. Bill 9, $63^{\text {rd }}$ General Assembly, $2^{\text {nd }}$ Session, 2008.

${ }^{414}$ Premier Robert Ghiz, ["Oral Questions: Provincial Election Date"] in Prince Edward Island, Legislative Assembly. Hansard, $64^{\text {th }}$ General Assembly, $4^{\text {th }}$ Session, 3 December 2013 (Charlottetown: Prince Edward Island Legislative Assembly, 2013), 658.

${ }^{415}$ Opposition Leader Olive Crane, [“Oral Questions: Provincial Election Date”] in Prince Edward Island, Legislative Assembly. Hansard, $64^{\text {th }}$ General Assembly, $4^{\text {th }}$ Session, 3 December 2013 (Charlottetown: Prince Edward Island Legislative Assembly, 2013), 658.

${ }^{416}$ Premier Robert Ghiz, ["Oral Questions: Provincial Election Date"] in Prince Edward Island, Legislative Assembly. Hansard, $64^{\text {th }}$ General Assembly, $4{ }^{\text {th }}$ Session, 3 December 2013 (Charlottetown: Prince Edward Island Legislative Assembly, 2013), 658.

${ }^{417}$ Premier Robert Ghiz, ["Orders of the Day (Government)"] in Prince Edward Island, Legislative Assembly. Hansard, 64 ${ }^{\text {th }}$ General Assembly, $4^{\text {th }}$ Session, 4 April 2014

(Charlottetown, Prince Edward Island Legislative Assembly, 2014), 1013.

${ }^{418}$ Ibid.

419 Ibid.

${ }^{420}$ Prince Edward Island, Legislative Assembly. An Act to Amend the Election Act. Bill 34, $64^{\text {th }}$ General Assembly, $4^{\text {th }}$ Session, 2014.

${ }^{421}$ Prince Edward Island, Election Act, Chapter E-1.1, 23 December 2017.

422 Andrew Vaughan, "Wade MacLauchlan Officially Takes Helm as PEI Premier," The

Globe and Mail, 23 February 2015 [accessed 24 May 2018].

$<$ https://www.theglobeandmail.com/news/national/wade-maclauchlan-officially-takes-the-helmas-pei-premier/article23149605/>

${ }^{423}$ Elections Prince Edward Island, Report of the Chief Electoral Officer for the

Provincial General Election, May 4, 2015 (Charlottetown: Legislative Assembly, 7 October 2015), 7.

${ }^{424}$ CBC News, "P.E.I. Premier Says There Will Be No Spring Election,” 7 April 2018 [accessed 24 May 2018]. <http://www.cbc.ca/news/canada/prince-edward-island/premier-wademaclauchlan-p-e-i-election-liberals-speculation-1.4610016>

${ }^{425}$ Cody MacKay, "Timeline for Next Election Remains Murky as Green MLA Presses Premier," CBC News, 19 May 2018 [accessed 23 May 2018].

$<$ http://www.cbc.ca/news/canada/prince-edward-island/pei-greens-ask-premier-about-provincialelection-timeline-1.4670672>

${ }^{426}$ Alberta, Legislative Assembly. An Act to Amend the Election Act, Bill 21. $27^{\text {th }}$ Legislature, $4^{\text {th }}$ Session, 2011.

${ }^{427}$ Verlyn Olsen, ["Bill 21: Election Amendment Act, 2011"], Alberta, Legislative Assembly, Alberta Hansard, $27^{\text {th }}$ Legislature, $4^{\text {th }}$ Session, Issue 38 (Edmonton: Legislature of Alberta, 22 November 2011): 1240. 
${ }^{428}$ Ibid.

429 Ibid.

${ }^{430}$ Harry Chase, ["Bill 21: Election Amendment Act, 2011”], Alberta, Legislative Assembly, Alberta Hansard, $27^{\text {th }}$ Legislature, $4^{\text {th }}$ Session, Issue 38 (Edmonton: Legislature of Alberta, 29 November 2011): 1501.

${ }^{431}$ Rachel Notley, [“Bill 21: Election Amendment Act, 2011"], Alberta, Legislative

Assembly, Alberta Hansard, $27^{\text {th }}$ Legislature, $4^{\text {th }}$ Session, Issue 38 (Edmonton: Legislature of Alberta, 29 November 2011): 1508.

${ }^{432}$ Ibid.

${ }^{433}$ Gary Mason, "Premier Jim Prentice Shrinks Alberta Cabinet, Appoints Two Outsiders," Globe and Mail, 15 September 2014.

${ }^{434}$ iPolitics, "'We'll Get Through This' - Jim Prentice in Conversation," 8 March 2015. http://www.ipolitics.ca/2015/03/08/we-will-get-through-this-jim-prentice-in-conversation/

${ }^{435}$ Matt Dykstra, “Alberta's Lt-Gov. Donald Ethell Talks About Budget 2015, Looming

Election," Edmonton Sun, 9 March 2015. http://www.edmontonsun.com/2015/03/09/albertas-ltgov-donald-ethell-talks-about-budget-2015-looming-election

${ }^{436}$ Parti québécois, "L’avenir du Québec est entre vos mains : la plateforme électorale du Parti Québécois,” 4 August 2012.

${ }^{437}$ Quebec, National Assembly. Loi modifiant la Loi électorale afin de prévoir des élections à date fixe, Bill 3. 40 ${ }^{\text {th }}$ Legislature, $1^{\text {st }}$ Session, 2013.

${ }^{438}$ Quebec, La loi électorale, chapitre E-3.3.

${ }^{439}$ Quebec, La loi sur l'assemblée national, chapitre A-23.1.

${ }^{440}$ Quebec, La loi électorale, chapitre E-3.3.

${ }^{441}$ Christine St-Pierre, "Étude détaillée du projet de loi no 3, Loi modifiant la Loi électorale afin de prévoir des élections à date fixe." In Quebec, National Assembly, Journal des débats de la Commission des institutions 43, no. 61, 4 June 2013.

${ }^{442}$ Ibid.

${ }^{443}$ Ibid. [Author's translation].

${ }^{444}$ Ibid. [Author's translation].

${ }^{445}$ Ibid.

${ }^{446}$ Guy Tremblay, "Étude détaillée du projet de loi no 3, Loi modifiant la Loi électorale afin de prévoir des elections à date fixe." In Quebec, National Assembly, Journal des débats de la Commission des institutions 43, no. 62, 5 June 2013. <http://www.assnat.qc.ca/fr/travauxparlementaires/commissions/ci-40-1/journal-debats/CI-130605.html>

${ }^{447}$ Ibid., author's translation

${ }^{448}$ Charles Lecavalier, "Élections provinciales: Marois ouvre la porte," Agence QMI, 6

February 2014. http://tvanouvelles.ca/lcn/infos/national/archives/2014/02/20140206-

163327.html

449 Ibid.

${ }^{450}$ Ibid

${ }^{451}$ Nova Scotia, General Assembly. An Act to Amend Chapter 140 of the Revised

Statutes, 1989, the Elections Act, Bill no. 74, 60 ${ }^{\text {th }}$ General Assembly, $2^{\text {nd }}$ Session, 2007. 452 Ibid.

${ }^{453}$ Nova Scotia, General Assembly. An Act to Amend Chapter 140 of the Revised

Statutes, 1989, the Elections Act, Bill No. 26, $61^{\text {st }}$ General Assembly, $2^{\text {nd }}$ Session, 2010. 
${ }^{454}$ Nova Scotia, General Assembly. An Act to Amend Chapter 5 of the Acts of 2011, the Elections Act, Bill no. 6, 62 ${ }^{\text {nd }}$ General Assembly, $1^{\text {st }}$ Session, 2013.

${ }^{455}$ CBC News, "Premier Stephen McNeil eyes fixed election dates: Progressive Conservative Leader Jamie Baillie calls for four-year terms," 3 December 2013. http://www.cbc.ca/news/canada/nova-scotia/premier-stephen-mcneil-eyes-fixed-election-dates1.2448576; Michael Lighthouse, "Nova Scotia Should Move to Adopt Fixed Election Dates, Says Report," Herald News, 29 April 2014 , http://thechronicleherald.ca/novascotia/1204017nova-scotia-should-move-to-adopt-fixed-date-elections-report-says

${ }^{456}$ Diana Whalen, [“Bill no. 6”], Nova Scotia, General Assembly, Hansard, $62^{\text {nd }}$

Assembly, $1^{\text {st }}$ Session, 13-06 (Halifax: General Assembly, 4 December 2013), 363. ${ }^{457}$ Ibid.

${ }^{458}$ Gordie Gosse, ["Bill no. 6"], Nova Scotia, General Assembly, Hansard, $62^{\text {nd }}$

Assembly, $1^{\text {st }}$ Session, 13-06 (Halifax: General Assembly, 4 December 2013), 367.

${ }^{459}$ Ibid., 368.

${ }^{460}$ Ibid., 372.

${ }^{461}$ Nova Scotia, General Assembly. An Act to Amend Chapter 5 of the Acts of 2011, the Elections Act, Bill No. 57, 62 ${ }^{\text {nd }}$ General Assembly, $2^{\text {nd }}$ Session, 24 October 2014.

462 John Lohr, ["Bill No. 57, Elections Act"], Nova Scotia, General Assembly. An Act to Amend Chapter 5 of the Acts of 2011, the Elections Act, Bill No. 57, $62^{\text {nd }}$ General Assembly, $2^{\text {nd }}$ Session, 12 November 2014, 2461-2464.

${ }^{463}$ John Lohr, ["Bill No. 57, Elections Act"], Nova Scotia, General Assembly. An Act to Amend Chapter 5 of the Acts of 2011, the Elections Act, Bill No. 57, 62 ${ }^{\text {nd }}$ General Assembly, $2^{\text {nd }}$ Session, 12 November 2014, 2462.

${ }^{464}$ John Lohr, ["Bill No. 57, Elections Act"], Nova Scotia, General Assembly. An Act to Amend Chapter 5 of the Acts of 2011, the Elections Act, Bill No. 57, $62^{\text {nd }}$ General Assembly, $2^{\text {nd }}$ Session, 12 November 2014, 2463.

${ }^{465}$ Maureen MacDonald, [“Bill No. 57, Elections Act”], Nova Scotia, General Assembly. An Act to Amend Chapter 5 of the Acts of 2011, the Elections Act, Bill No. 57, 62 ${ }^{\text {nd }}$ General Assembly, $2^{\text {nd }}$ Session, 12 November 2014, 2468.

${ }^{466}$ Ibid.

${ }^{467}$ Nova Scotia. Elections Nova Scotia. Report on the Conduct of the October 8, 2013

Provincial General Election and Recommendations for Legislative Change, Volume II, written by Richard Temporale, Chief Electoral Officer (Halifax: Chief Electoral Officer, April 2014), 31-32.

468 Ibid., 32.

${ }^{469}$ CBC News, "Nova Scotia Balks at Fixed Election Date: Stephen McNeil Says that

Fixed Election Dates Don't Work," 9 April 2015 [accessed 24 May 2018].

$<$ http://www.cbc.ca/news/canada/nova-scotia/nova-scotia-government-balks-at-fixed-electiondate-1.3025236>

${ }^{470}$ Arthur Berridale Keith, Responsibility Government in the Dominions, Volume 1 (Oxford: Clarendon Press, 1912), 83; Alpheus Todd, Parliamentary Government in the British Colonies, $2^{\text {nd }} E d$ (London: Longman's, Green, and Co., 1894), 107.

${ }^{471}$ Alpheus Todd, Parliamentary Government in the British Colonies, $2^{\text {nd }}$ Edition

(London: Longmans, Green, and Co., 1894), 78. 
${ }^{472}$ Canada, Privy Council Office, Order-in-Council PC 2010-0566: “Appointment of George Tuccaro of Yellowknife, Northwest Territories, To Be Commissioner of the Northwest Territories and to Hold Office During Pleasure for a Term of Five Years," 11 May 2010; Canada, Privy Council Office, Order-in-Council PC 2015-0086: "Reappointment of George Tuccaro of Yellowknife, Northwest Territories To Hold Officer During Pleasure for A Term of One Year, Effective, May 11, 2015,” 2 February 2015.

${ }^{473}$ Canada, Department of Indian and Northern Affairs, Commissioners of the Territories (Ottawa: Her Majesty the Queen in Right of Canada, 2000);

${ }^{474}$ John Duncan, Minister of Indian and Northern Affairs, Letter of Instructions to George Tuccaro, Commissioner of the Northwest Territories, 6 October 2010.

${ }^{475}$ Patrick Barthold, Director of the Northern Governance and Partnerships Directorate, e-mail correspondence with author, 22 June 2017.

${ }^{476}$ Rosemary Cairns, "Becoming Master in Its Own House: The Story of the NWT Legislative Assembly," Canadian Parliamentary Review 5, no. 2 (1982): 3-5; Gurston Dacks, "Politics on the Last Frontier: Consociationalism in the Northwest Territories," Canadian Journal of Political Science 19, no. 2 (June 1986): 345-361; Brian Lewis, "The Development of Responsible Government in the Northwest Territories, 1976-1998," Canadian Parliamentary Review 21, no. 2 (Summer 1998): 12-17; Chris Pearson, "Yukon's Responsible Government," Canadian Parliamentary Review 3, no. 1 (1980): 21-26.

${ }^{477}$ Jane Groenewegen in ["Motion 8-16(3) - Revocation of Appointments of the Premier and Executive Council"] in Northwest Territories, Legislative Assembly, Hansard, $16^{\text {th }}$ Assembly, $3^{\text {rd }}$ Session, 6 February 2009, 2033-2056.

${ }^{478}$ John Main in ["Motion 009-5(2): Removal of the Member for Aggu from the Executive Council of Nunavut," in Nunavut, Legislative Assembly, Nunavut Hansard, $5^{\text {th }}$ Assembly, $1^{\text {st }}$ Session, 14 June 2018, 45-60.

${ }^{479}$ The Honourable Michael Ignatieff in [Business of Supply: Opposition Motion Confidence in the Government"] in Canada, House of Commons, Hansard (Debates), $40^{\text {th }}$ Parliament, $3^{\text {rd }}$ Session, volume 145, no. 149, 25 March 2011, 9246; The Honourable Stephen Harper in [Government Orders (Supply): Opposition Motion - Confidence in the Government"] in Canada, House of Commons, Hansard (Debates), $38^{\text {th }}$ Parliament, $1{ }^{\text {st }}$ Session, volume 140, no. 157,24 November $2005,10073$.

${ }^{480}$ Jack Hicks and Graham White, Made in Nunavut: An Experiment in Decentralized Government (Vancouver: University of British Columbia Press, 2015), 8.

${ }^{481}$ Elections and Plebiscites Act, S.N.W.T. 2006, c.15.

${ }^{482}$ Northwest Territories Act, R.S.C., 1985, c. N-27.

${ }^{483}$ David Ramsey in ["Item 19: Consideration in Committee of the Whole of Bill 15"] in Northwest Territories, Legislative Assembly, Hansard, $15^{\text {th }}$ Assembly, $5^{\text {th }}$ Session, 30 October 2006, 584.

${ }^{484}$ Sandy Lee in ["Item 19: Consideration in Committee of the Whole of Bill 15"] in Northwest Territories, Legislative Assembly, Hansard, $15^{\text {th }}$ Assembly, $5^{\text {th }}$ Session, 30 October 2006, 585.

${ }^{485}$ Nunavut Act, S.C. 1993, c. 28.

${ }^{486}$ Nunavut Elections Act, S.Nu. 2002, c.17. 
${ }^{487}$ The Honourable George Qulaut in ["Bill 01 - An Act to Provide for a Fixed Election Date - Consideration in Committee "] in Nunavut, Legislative Assembly, Nunavut Hansard, $4^{\text {th }}$ Assembly, $1^{\text {st }}$ Session, 6 March 2014, 79.

${ }^{488}$ The Honourable George Qulaut in ["Bill 01 - An Act to Provide for a Fixed Election Date - Consideration in Committee "] in Nunavut, Legislative Assembly, Nunavut Hansard, $4^{\text {th }}$ Assembly, $1^{\text {st }}$ Session, 6 March 2014, 79.

${ }^{489}$ Jennifer Loach, Parliament Under the Tudors (Oxford: Clarendon Press, 1991), 5.

${ }^{490}$ Peter H. Russell, "Prorogation - Prime Ministers Must Not Become Kings," Canada

Watch (Spring 2011): 17.

${ }^{491}$ Loach 1991, 5.

${ }^{492}$ Ibid., x.

${ }^{493}$ David Starkey, Crown \& Country -The Kings \& Queens of England: A History. (London: HarperPress, 2010), 332-333.

${ }^{494}$ Ibid., 330-335. In 1625, Charles I dissolved the "Useless Parliament" - so called because it had passed no supply -after it had sat for two months. In 1626, he dissolved his second parliament in order to prevent it from impeaching Lord Buckingham. He summoned his third parliament in 1628 and dissolved it in 1629.

${ }^{495}$ Ibid., 330-335.

${ }^{496}$ Samuel Rawson Gardiner, Constitutional Documents of the Puritan Revolution, 16281660 (Oxford: Clarendon Press, 1889), 74.

${ }^{497}$ Ibid., 74-84. In this era, the King could still adjourn each House himself. Later the Commons and the Lords claimed the authority to govern their own proceedings as part of parliamentary privilege.

${ }^{498}$ Ibid., 87.

${ }^{499} \mathrm{Ibid}$.

${ }^{500}$ Blackstone 1893, 187.

${ }^{501}$ British History Online, "An Act for the assembling and holding of Parliaments once in Three yeares at the least, And for the repeale of an Act entituled An Act for the preventing of Inconveniencies happening by the long Intermission of Parliaments," Statutes of the Realm,

Volume 5: 1628-1680.

${ }^{502}$ Ibid.

${ }^{503}$ James Mahoney and Kathleen Thelen, "A Theory of Gradual Institutional Change," in Explaining Institutional Change: Ambiguity, Agency, and Power, edited by James Mahoney and Kathleen Thelen, 1-37 (Cambridge: Cambridge University Press, 2010): 4.

${ }^{504}$ British History Online, "An Act for the frequent meeting and calling of parliaments,"

Statutes of the Realm, Volume 6: 1685-1694.

${ }^{505}$ Hogg et al. 2011, 22.

${ }^{506}$ Robert Craig, "Restoring Confidence: Replacing the Fixed-Term Parliaments Act, 2011" The Modern Law Review 81, no.3 (2018), 496.

${ }^{507}$ Ibid., 494.

${ }^{508}$ United Kingdom. Parliament of the United Kingdom, Fixed-Term Parliaments Act, 2011 (London: Parliamentary Copyright, 2011), 1-4. British statues normally delegate authority to an individual minister rather than to Her Majesty-in-Council, which in practice means the Cabinet acting collectively. In contrast, the Parliament of Canada normally delegates authority to the Governor-in-Council. 
${ }^{509}$ United Kingdom. Cabinet Office, The Cabinet Manual: A Guide to Laws, Conventions and the Rules on the Operations of Government. 1st Ed. (London: Crown Copyright, October 2011): 13.

${ }^{510}$ United Kingdom, House of Commons, Written Evidence Submitted by Professor Robert Hazell, Standing Committee on Procedure and House Affairs (London: Parliament of the United Kingdom, 9 September 2010), Ev 34, Ev 42.

511 Ibid., 24-25.

512 Philip Norton, "Government Defeats in the House of Commons: The British Experience," Canadian Parliamentary Review (Winter 1985-1986): 6.

513 Ottawa Citizen, "Tories Declare Another Confidence Test As Parliamentary Staredown Continues," 7 February 2008.

${ }^{514}$ Peter Neary, “Confidence: How Much Is Enough?” Constitutional Forum constitutionnel 18, no. 1 (2009): 51-54; United Kingdom. Cabinet Office, The Cabinet Manual - Draft: A Guide to Laws, Conventions and the Rules on the Operations of Government. (London: Crown Copy-right, December 2010): 25.

${ }^{515}$ Eugene Forsey, "Government Defeats in the House of Commons, 1867-1873," The Canadian Journal of Economics and Political Science 29, no. 3 (August 1963): 364-367. ${ }^{516}$ Andrew Heard, "The Governor General's Decision to Prorogue Parliament: A Chronology and Assessment," Constitutional Forum (2009-2010): 3; Canada, House of Commons, Notice Paper, 40th Parliament, 1st session., No. 10 (1 December 2008)

${ }^{517}$ Aucoin et al. 2011, 222.

${ }^{518}$ United Kingdom, House of Lords, $8^{\text {th }}$ Report of the Session 2010-11 - Fixed-Term Parliaments Bill: Report with Evidence, Select Committee on the Constitution (London: Parliament of the United Kingdom, 16 December 2010), 29; Pepall 2010, 25. ${ }^{519}$ United Kingdom. Parliament of the United Kingdom, Fixed-Term Parliaments Act (London: Parliamentary Copyright, 2011), 1-4.

${ }^{520}$ United Kingdom. Cabinet Office, The Cabinet Manual: A Guide to Laws, Conventions and the Rules on the Operations of Government. 1st Edition. (London: Crown Copyright, October 2011): 17.

${ }^{521}$ United Kingdom. Cabinet Office, The Cabinet Manual — Draft: A Guide to Laws, Conventions and the Rules on the Operations of Government. (London: Crown Copyright, December 2010): 24.

${ }^{522}$ United Kingdom. Cabinet Office, The Cabinet Manual: A Guide to Laws, Conventions and the Rules on the Operations of Government. 1st Ed. (London: Crown Copyright, October 2011): 15.

${ }^{523}$ Vernon Bogdanor, The Coalition and the Constitution (Oxford, Hart Publishers Ltd., 2011), 114 . ${ }^{524}$ Ibid., 29.

${ }^{525}$ United Kingdom, Government Response to the Report of the Political and Constitutional Reform Committee on the Fixed-Term Parliaments Bill: Presented to Parliament by the Minister for Political and Constitutional Reform (London: Crown copyright, November 2010), at para. 54.

${ }^{526}$ United Kingdom, House of Lords, $8^{\text {th }}$ Report of the Session 2010-11 - Fixed-Term Parliaments Bill: Report with Evidence, Select Committee on the Constitution (London: Parliament of the United Kingdom, 16 December 2010), 29. 
${ }^{527}$ United Kingdom, Government Response to the Report of the Political and Constitutional Reform Committee on the Fixed-Term Parliaments Bill: Presented to Parliament by the Minister for Political and Constitutional Reform (London: Crown copyright, November 2010), at para. 56.

${ }^{528}$ Vernon Bogdanor, The Coalition and the Constitution (Oxford: Hart Publishing, Ltd., 2011), 112.

${ }^{529}$ United Kingdom, Parliament of the United Kingdom, Fixed-Term Parliaments Bill, Bill 64, 22 July 2010.

${ }^{530}$ United Kingdom, Government Response to the Report of the Political and Constitutional Reform Committee on the Fixed-Term Parliaments Bill: Presented to Parliament by the Minister for Political and Constitutional Reform (London: Crown copyright, November 2010), at para. 52.

${ }^{531}$ United Kingdom, House of Commons, $2^{\text {nd }}$ Report of the Session 2010-11 - FixedTerm Parliaments Bill: Report Together with Formal Minutes, Oral and Written Evidence, Political and Constitutional Reform Committee (London: Parliament of the United Kingdom, 9 December 2010), 14.

${ }^{532}$ Ibid.

533 Ibid.

${ }^{534}$ Chris Bryant ["Fixed-Term Parliaments Bill"] in United Kingdom, House of Commons, Parliamentary Debates (Hansard), volume 521, no. 100, 18 January 2011 (London: House of Commons, 2011), 733.

${ }^{535}$ Ibid., 736. Chris Bryant also cited Prime Minister Harper's use of prorogation in 2008 and 2009 as examples.

${ }^{536}$ United Kingdom, Government Response to the Report of the Political and Constitutional Reform Committee on the Fixed-Term Parliaments Bill: Presented to Parliament by the Minister for Political and Constitutional Reform (London: Crown Copyright, November 2010), at para. 50.

${ }_{538}^{537}$ Ibid.

${ }^{538}$ Ibid., at para. 50, and para. 3 .

539 Ibid., at para. 3-4.

${ }^{540}$ Nicholas A. MacDonald and James W.J. Bowden, "No Discretion: On Prorogation and the Governor General," Canadian Parliamentary Review 34, no. 1 (Spring 2011): 7-16. ${ }^{541}$ United Kingdom. Parliament of the United Kingdom, Scotland Act (London: Parliamentary Copyright, 1998), 3-4.

${ }^{542}$ United Kingdom, House of Commons, $2^{\text {nd }}$ Report of the Session 2010-11 - FixedTerm Parliaments Bill: Report Together with Formal Minutes, Oral and Written Evidence, Political and Constitutional Reform Committee (London: Parliament of the United Kingdom, 9 December 2010), 15.

${ }^{543}$ United Kingdom, House of Lords, $8^{\text {th }}$ Report of the Session 2010-11 - Fixed-Term Parliaments Bill: Report with Evidence, Select Committee on the Constitution (London: Parliament of the United Kingdom, 16 December 2010), 4.

${ }^{544}$ United Kingdom, Government of the United Kingdom. The Governance of Britain (London: Crown copyright, July 2007), 5.

${ }^{545}$ Ibid. at para. 14. 
546 The Labour Party Manifesto 2010: A Future Fair for All (London: Labour Party, 2010), 9:2.

547 Liberal Democrat Manifesto 2010: Change That Works For You - Building a Fairer

Britain (London: Liberal-Democratic Party, 2010), 88.

${ }^{548}$ United Kingdom, House of Commons, $2^{\text {nd }}$ Report of the Session 2010-11 - Fixed-

Term Parliaments Bill, Political and Constitutional Reform Committee, Written Evidence

Submitted by Professor Robert Blackburn (FTPB 04) (London: Parliament of the United

Kingdom, 9 December 2010), Ev 45.

${ }^{549}$ Catherine Mayer, "Tories Dare Labour to Call an Election," Time, Thursday, 4

October 2007; BBC News, "Brown Rules Out An Autumn Election," 6 October 2007.

${ }^{550}$ Coalition Agreement for Stability and Reform (London: Conservative Party and

Liberal Democrats, May 2010), 1.

${ }^{551}$ Vernon Bogdanor, The Coalition and the Constitution (Oxford: Hart Publishing,

2011), 107.

${ }^{552}$ United Kingdom, House of Commons, Fixed-Term Parliaments Bill, Second Report of

Session 2010-2011, Standing Committee on Procedure and House Affairs (London: Parliament

of the United Kingdom, 9 September 2010), 3.

${ }^{553}$ United Kingdom, House of Commons, $2^{\text {nd }}$ Report of the Session 2010-11 - Fixed-

Term Parliaments Bill, Political and Constitutional Reform Committee, Written Evidence

Submitted by Professor Robert Blackburn (FTPB 04) (London: Parliament of the United

Kingdom, 9 December 2010), Ev 45.

${ }^{554}$ Ibid.

${ }^{555}$ Raymond Youngs and Nicklaus Thomas-Symonds, "The Problem of the 'Lame Duck'

Government: A Critique of the Fixed-term Parliaments Act," Parliamentary Affairs 66 (2013):

545.

${ }^{556}$ BBC News, "Theresa May's General Election Statement in Full, 17 April 2017.

$<$ https://www.bbc.com/news/uk-politics-39630009>

${ }^{557}$ Richard Kelly and Nicola Newson, Wash-Up 2010: Research Paper 11/18 (London:

House of Commons Library, 11 February 2011), 2.

${ }^{558}$ United Kingdom, The Gazette: London Gazette, "Proclamations: By the Queen

Appointing Thursday the 8th Day of June 2017 as the Polling Day for the General Election of the Next Parliament," (London: Crown Copyright, 25 April 2017), issue no. 61912, page number 8774.

${ }^{559}$ Metro Newspaper UK, “Theresa May delivers speech outside number 10 Downing

Street to mark the dissolution of Parliament," 3 May 2017.

$<$ https://www.youtube.com/watch?v=qUluFdU-6Jw>

${ }^{560}$ Peter Bone in ["Early Parliamentary General Election"] in United Kingdom, House of

Commons, Hansard, 56th Parliament, volume 624, 19 April 2017, column 697.

${ }^{561}$ Jacob Rees-Mogg in ["Early Parliamentary General Election"] in United Kingdom,

House of Commons, Hansard, 56th Parliament, volume 624, 19 April 2017, column 697.

${ }^{562}$ Peter Bone in ["Early Parliamentary General Election"] in United Kingdom, House of

Commons, Hansard, 56th Parliament, volume 624, 19 April 2017, column 698.

563 Jeremy Corbyn in "Jeremy Corbyn on Andrew Marr Show (FULL Interview)-BBC

News," 23 April 2017.

$<$ https:/www.youtube.com/watch?time_continue $=60 \& v=X q v 001 U \_8 s>$ 
564 Tim Farron, Tweet: "This is your chance to change the direction of the country," 18 April 2017.

$<$ https://twitter.com/timfarron/status/854278087713988609/photo/1?ref_src=twsrc\%5Etf w\&ref_url=https $\% 3 \mathrm{~A} \% 2 \mathrm{~F} \% 2 \mathrm{Fparliamentum.org} \% 2 \mathrm{~F} 2017 \% 2 \mathrm{~F} 04 \% 2 \mathrm{~F} 18 \% 2 \mathrm{Fb}$ ritish-primeminister-theresa-may-calls-for-an-early-election-under-the-fixed-term-parliaments-act $\% 2 \mathrm{~F}>$ ${ }_{565}$ Germany, Basic Law for the Federal Republic of Germany, 23 May 1949.

566 John Pepall, Against Reform (Toronto: University of Toronto Press, 2010), 26.

${ }^{567}$ BBC News, "Election 2017: Results," 8 June 2017. $<$ https://www.bbc.com/news/election/2017/results $>$ 568 Ibid.

${ }^{569}$ Ibid.

${ }^{570}$ BBC News, “Theresa May’s Victory Speech Outside Number 10,” 9 June 2017. $<$ https://www.bbc.com/news/election-2017-40223959>

${ }^{571}$ United Kingdom, Prime Minister's Office, "Policy Paper: Confidence and Supply Agreement between the Conservative and Unionist Party and the Democratic Unionist Party," 26 June 2017. <https://www.gov.uk/government/publications/conservative-and-dup-agreementand-uk-government-financial-support-for-northern-ireland $>$

572 Metro Newspaper UK, "Theresa May delivers speech outside number 10 Downing Street to mark the dissolution of Parliament," 3 May 2017.

$<$ https:/www.youtube.com/watch?v=qUluFdU-6Jw $>$

573 The Conservative and Unionist Party Manifesto 2017: Forward, Together -- Our Plan for a Stronger Britain and Prosperous Future (London: Conservative and Unionist Party, 2017), 43; The Labour Party Manifesto 2010: A Future Fair for All (London: Labour Party, 2010), 9:2. ${ }^{574}$ United Kingdom. Parliament of the United Kingdom, Fixed-Term Parliaments Act, 2011 (London: Parliamentary Copyright, 2011), 1-4.

${ }^{575}$ Craig 2018, 494.

576 Ibid.

577 Ibid.

${ }^{578}$ Ibid, 500.

${ }^{579}$ Ibid.

5801715 Chapter 381 George 1 St 2.

The Septennial Act, 1715 stated simply: "Parliaments shall have Continuance for seven Years, unless sooner dissolved by the King."

${ }^{581}$ Ibid, 501-504.

582 Ibid, 505.

${ }^{583} \mathrm{Ibid}, \mathrm{s}, 55-507$.

${ }^{584}$ Ibid, 505-506.

${ }^{585}$ Ibid, 506-507.

${ }^{586}$ Ibid, 505, 506 .

587 Ibid, 503.

588 Rand Dyck, Canadian Politics: Critical Approaches, $5^{\text {th }}$ edition (Toronto: ThomsonNelson, 2008), 343-344.

589 Teresa Wright, “Election Date May Be Pushed Back," The Guardian, 1 December 2012; Ryan Ross, "Prince Edward Island Election Date Changed to Spring for 2016," The Guardian, 4 December 2013; Joe Couture, "Wall Says 2016 Election 'A Safe Bet'," The Star- 
Phoenix, 12 July 2013; Larry Kusch, "NDP-Tory Battle Already On? PST Move Ignited Race, Top Selinger Aid Says," Winnipeg Free Press, 26 May 2013.

${ }^{590}$ CBC News, "Wall Asks Harper to Change Election Date," 7 December 2011.

${ }^{591}$ Premier Robert Ghiz, ["Orders of the Day (Government)"] in Prince Edward Island, Legislative Assembly. Hansard, $64^{\text {th }}$ General Assembly, $4^{\text {th }}$ Session, 4 April 2014

(Charlottetown, Prince Edward Island Legislative Assembly, 2014), 1013.

592 There's a good political science paper, or even a thesis, to be written on how Prime Minister Harper has dispensed with traditional executive federalism; he refuses to hold annual First Ministers' Conferences and instead holds bilateral meetings with each Premier frequently but separately. And instead of meeting at elaborate First Ministers' Conferences, the 10 Premiers now meet semi-annually through the Council of the Federation and sort out provincial issues amongst themselves, without the Prime Minister and interference from Ottawa.

${ }^{593}$ Conacher v. Canada (Prime Minister), 2009 FC 920, at para 62.

${ }^{594}$ David E. Smith, The Invisible Crown: The First Principle of Canadian Government (Toronto: University of Toronto, 1995), 130.

595 James W.J. Bowden and Nicholas A. MacDonald, "Writing the Unwritten: The Officialization of Conventions in Canada, the United Kingdom, New Zealand, and Australia." Journal of Parliamentary and Political Law 6 no. 2 (August 2012): 375.

596 Russell 2008, 28.

${ }^{597}$ D. Michael Jackson, The Crown and Canadian Federalism (Toronto: Dundurn, 2013),

64.

598 Preston Manning, 56 Reasons Why You Should Support the Reform Party of Canada

(Calgary: Reform Party of Canada, 1992).

${ }^{599}$ Canada, Parliament of Canada, House of Commons. Debates. $36^{\text {th }}$ Parliament, Second

Session, Number 121, Monday, 25 September 2000. (Ottawa: Parliament of Canada, 2000). ${ }^{600}$ Ibid.

${ }^{601}$ Canada, Parliament of Canada, House of Commons. Debates. $36^{\text {th }}$ Parliament, Second Session, Number 132, Thursday, 19 October 2000. (Ottawa: Parliament of Canada, 2000). ${ }^{602}$ Dodek 2010, 222.

${ }^{603}$ Alpheus Todd, On Parliamentary Government in England: Its Origin, Development, and Practical Operation, $2^{\text {nd }}$ ed., vol 2, edited by Arthur Hamlyn Todd (London: Longman's, Green, and Co., 1889), 503.

${ }^{604}$ Ibid., 504.

${ }^{605}$ Alpheus Todd, On Parliamentary Government in the British Colonies, $2^{\text {nd }}$ Edition, edited by Arthur Hamlyn Todd (London: Longman's, Green, and Co., 1894), 659-661. ${ }^{606}$ Ibid., 665-666, 677-678.

${ }^{607}$ Canada, Parliament of Canada, "Memorandum from Sir Charles Tupper to His

Excellency the Governor General, under date $6^{\text {th }}$ July 1896," Sessional Papers, no.7 (Ottawa:

Queen's Printer, 1896), 7; E. George Smith, "King Resigns When His Excellency Refuses

Dissolution," The Globe, 29 June 1926.

${ }^{608}$ Carman Miller, The Canadian Career of the Fourth Earl of Minto: The Education of a

Viceroy (Waterloo, Ontario: Wilfrid Laurier University Press, 1980), 110-114.

${ }^{609}$ Todd 1889, 505.

${ }^{610}$ Ibid., 505-506.

${ }^{611}$ Forsey and Eglington 1985, 226. 
${ }^{612}$ D. Michael Jackson, The Crown and Canadian Federalism (Toronto: Dundurn, 2013), 162. 2011), 115 .

${ }^{613}$ Vernon Bogdanor, The Coalition and the Constitution (Oxford: Hart Publishing, ${ }^{614}$ Bogdanor 2011, 115-117. ${ }^{615}$ Todd $1889,508$.

${ }^{616}$ Shawn McCarthy and Paul Adams, "PM Says Choice is Between Two Distinct Visions of Canada; Argues Alliance Had Already Begun Election Advertising," The Globe and Mail, 23 October 2000, A1.

${ }^{617}$ Bogdanor 2011, 121.

${ }^{618}$ Ibid.

${ }^{619}$ When the prime minister appointed an elected MP to the Privy Council (a position of emolument under the Crown), the new Minister had to resign and run for re-election in a byelection before being sworn in to cabinet. The Province and Dominion of Canada had adopted this principle from the United Kingdom. The Westminster Parliament first mandated ministerial by-elections during the reign of Queen Anne, well before modern cabinet government had emerged in the United Kingdom and long before Responsible Government had been granted to the colonies. This procedure was seen as a means of limiting the executive's authority to turn MPs into Crown placemen, and it was motivated by the same fears that prime ministerial patronage power elicit today. Ministerial by-elections also highlighted the separation of powers between the executive and legislature.

Both the Province of Canada and the Dominion of Canada mandated ministerial byelections in statute; the Parliament of Canada abolished the practice in 1931, following in the United Kingdom's repeal of ministerial by-elections in 1926. The King-Byng Affair is what ultimately spurred Parliament to abolishing ministerial by-elections. The House of Commons withdrew its confidence from Meighen's government after only a few days in the absence of Meighen and his cabinet ministers, who had all vacated their seats in order to pursue re-election in by-elections. Without ministerial by-elections, the Meighen government would have commanded a larger majority and would almost certainly have survived longer than it did. See Martin Pugh, "'Queen Anne Is Dead': The Abolition of Ministerial By-Elections, 1867-1926," Parliamentary History 21, no. 3 (2002): 351-366 and Statute 21-22 George V, chapter 52: An Act to remove the necessity of re-election of Members of the House of Commons of Canada on acceptance of office, 1931.

${ }^{620}$ Canada. Department of Canadian Heritage. Ceremonial and Protocol Handbook. (Ottawa: Government of Canada, c. 1998): G.4-2; Henri Brun, Guy Tremblay, and Eugénie Brouillet, Droit constitutionnel. 5th Ed. (Montreal : Éditions Yvon Blais, 2008): 371.

${ }^{621}$ Pepall 2010, 13.

${ }^{622} \mathrm{Ibid} ., 14$.

${ }^{623}$ Bogdanor 2011, 114.

${ }^{624}$ Conacher v. Canada (Prime Minister), 2009 FC 920 (Memorandum of Fact and Law

of the Respondent at para. 84).

${ }^{625} \mathrm{Ibid}$., at para. 89.

${ }^{626}$ Pepall 2010, 20-21.

${ }^{627}$ Adam Dodek, "The Past, Present and Future of Fixed Election Dates in Canada," Journal of Parliamentary and Political Law 4 (2010): 216. 
${ }^{628}$ Adam Dodek, "The Past, Present and Future of Fixed Election Dates in Canada," Journal of Parliamentary and Political Law 4 (2010): 224.

${ }^{629}$ Russell 2008, 141.

${ }^{630}$ Ibid., 142.

${ }^{631}$ Ibid., 140.

${ }^{632}$ Peter H. Russell, Two Cheers for Minority Government: The Evolution of Canadian Parliamentary Democracy (Toronto: Emond Montgomery Publications Limited, 2008): 134-142; Henry Milner, "Fixing Canada's Unfixed Election Dates," Institute for Research on Public Policy: Policy Matters 6, no. 6 (December 2005): 3.

${ }^{633}$ Andrew Heard, "Conacher Missed the Mark on Constitutional Conventions and Fixed Election Dates," Constitution forum constitutionnel 19, no. 1 (2010): 21-32; Andrew Heard, "Constitutional Conventions: The Heart of the Living Constitution," Journal of Parliamentary and Political Law 6, no. 2 (August 2012): 319-338

${ }^{634}$ Pepall 2010, 27.

${ }^{635}$ Canada. Library of Parliament, Bill C-16: An Act to Amend the Canada Elections Act, James R. Robertson. (Ottawa: Her Majesty the Queen in Right of Canada, 3 May 2007): 9-10. ${ }^{636}$ Audrey O'Brien and Marc Bosc, House of Commons Procedure and Practice, 2nd Ed. (Ottawa: House of Commons and Editions Yvon Blais, 2009), 386. O'Brien and Bosc say, "Since 2007, the Canada Elections Act has contained provisions limiting the duration of a Parliament to four years." However, the experience of the 41st Parliament shows that the maximum life of the parliament is in fact not precisely 48 months.

${ }^{637}$ Christian Leuprecht and James T. McHugh, "Fixed Election Cycles: A Genuine Alternative to Responsible and Responsive Government," Commonwealth and Comparative Politics 46, no. 4 (November 2008): 428.

${ }^{638}$ Philippe Lagassé, "Parliamentary and Judicial Ambivalence Toward Executive Prerogative Powers in Canada," Canadian Public Administration 55, no. 2 (June 2012): 177. ${ }^{639}$ Alan Hamlin, "Fixed-Term Parliaments: Electing the Opposition," Politics 30, no.1 (2010): 22 .

${ }^{640}$ Alan Hamlin, "Fixed-Term Parliaments: Electing the Opposition," Politics 30, no.1

(2010): 23 .

F41 Forsey and Eglington 1985, 221.

${ }^{642}$ Ibid.

${ }^{643}$ Ibid., 222, 223, 224.

${ }^{644}$ Ibid., 229.

${ }^{645}$ Ibid., 230.

${ }^{646}$ Forsey and Eglington 1985, 10.

${ }^{647}$ Peter Aucoin, Mark Jarvis, and Lori Turnbull, Democratizing the Constitution:

Reforming Responsible Government (Toronto: Emond-Montgomery Publishing, 2011): 108. ${ }^{648}$ Ibid., 213.

${ }^{649}$ Peter H. Russell, "Prorogation - Prime Ministers Must Not Become Kings," Canada

Watch (Spring 2011): 17.

${ }^{650}$ Patrice Dutil, Prime Ministerial Power in Canada: Its Origins under Macdonald,

Laurier, and Borden (Vancouver: University of British Columbia Press, 2017)

${ }^{651}$ Canada. Privy Council Office, Order-in-Council 1896-1853, "Memorandum

Regarding Certain of the Functions of the Prime Minister," 1 May 1896; Canada. Privy Council 
Office, Order-in-Council 1896-2710, "Memorandum Regarding Certain of the Functions of the Prime Minister," 13 July 1896; Privy Council Office, Order-in-Council 1911-2437, "Memorandum Regarding Certain of the Functions of the Prime Minister," 10 October 1911; Privy Council Office, Order-in-Council 1920-1639, "Memorandum Regarding Certain of the Functions of the Prime Minister," 19 July 1920; Privy Council Office, Order-in-Council 19301930, "Memorandum Regarding Certain of the Functions of the Prime Minister," 7 August 1930; Privy Council Office, Order-in-Council 1935-3374, "Memorandum Regarding Certain of the Functions of the Prime Minister," 25 October 1935.

${ }^{652}$ Canada. Privy Council Office, Manual of Official Procedure of the Government of Canada: Appendices, Henry F. Davis and André Millar.(Ottawa, Government of Canada, 1968): 634.

${ }^{653}$ Canada. Privy Council Office, Access to Information Request on Instruments of Advice, A-2015-00504, page 1.

${ }^{654}$ Aucoin 2011, 220.

${ }^{655}$ Ibid., 222.

656 Ibid., 220.

${ }^{657}$ Ibid.

${ }^{658}$ Ibid.

659 Ibid.

${ }^{660}$ Newman 2016, 112-115.

${ }^{661}$ In fact, the Privy Council Office shows that the Prime Minister alone requests that the Governor General grant a bill Royal Consent through an instrument of advice. Prime Minister Trudeau I issued an instrument of advice asking that the Governor General give Royal Consent to a bill pertaining to pensions to civil servants on 24 June 1980, because pensions were traditionally a prerogative authority of the Crown and bestowed upon favoured subjects. Canada, Privy Council Office, Instrument of Advice from Prime Minister Trudeau to Governor General Schreyer on Royal Consent to "An Act to amend the Financial Administration Act (garnishment and attachment)," 12 March 1979, page 34 of ATIP A-2015-00504.

662 Newman 2009, 229.

${ }^{663}$ Ontario, Ministry of Natural Resources, "Disposition of Government Land to Other Governments and Government Agencies, Policy PL 4.09.01," 24 January 2006; Paul Lordon, Crown Law (Ottawa: Ministry of Supply and Services, 1991), 283. As Lordon writes, "A transfer of property between the federal government and a province is not done by ordinary conveyance, because of the principle of indivisibility of the Crown. Her Majesty is the owner of the property whether in right of Canada or the province and cannot grant to Herself. Only administrative control of property passes. The transfer is, therefore, made by reciprocal Orders in Council and is confirmed by statute where third-party rights are involved." 